
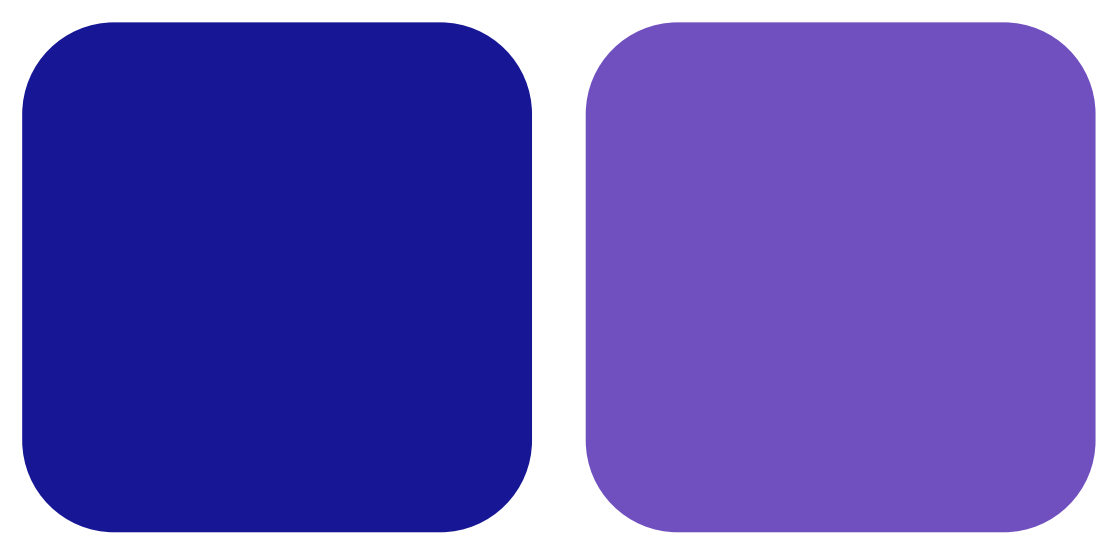

0
0

$\infty$

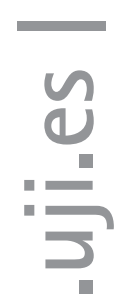

告
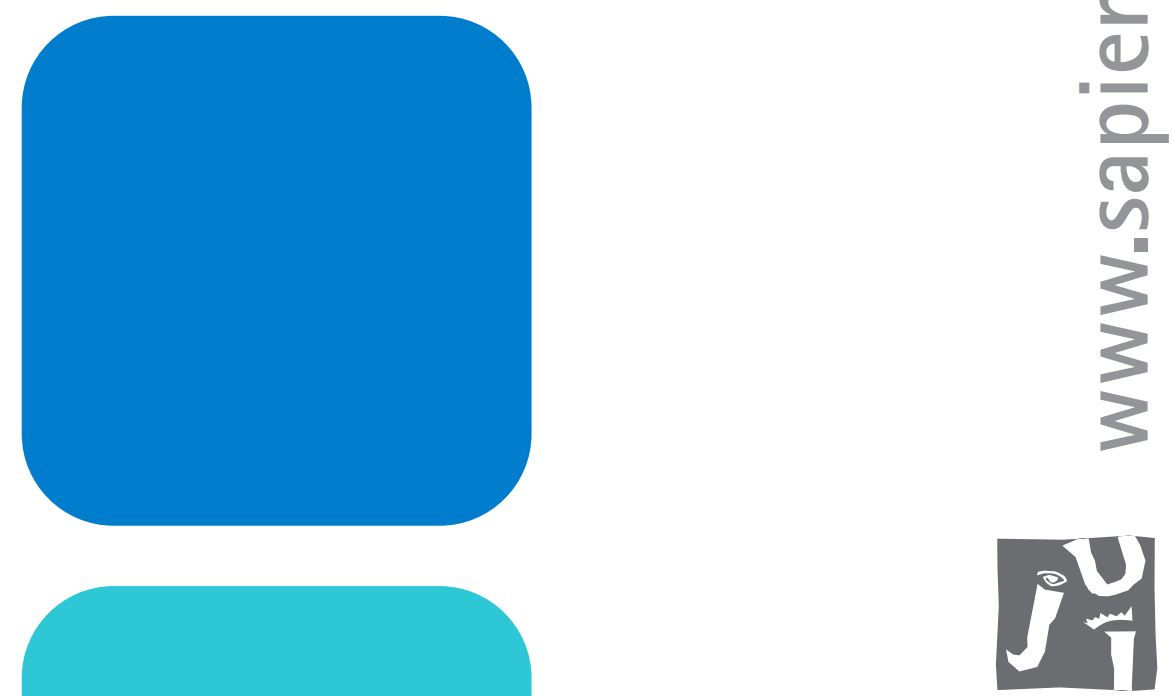

UNIVERSITAT

JAUME•I

\title{
Els Nombres Naturals a l'aula de Primària
}

Manuel Alcalde Esteban Inmaculada Pérez Serrano

Gil Lorenzo Valentín 


\section{Els Nombres Naturals a l'aula de Primària}

Manuel Alcalde Esteban

Inmaculada Pérez Serrano

Gil Lorenzo Valentín

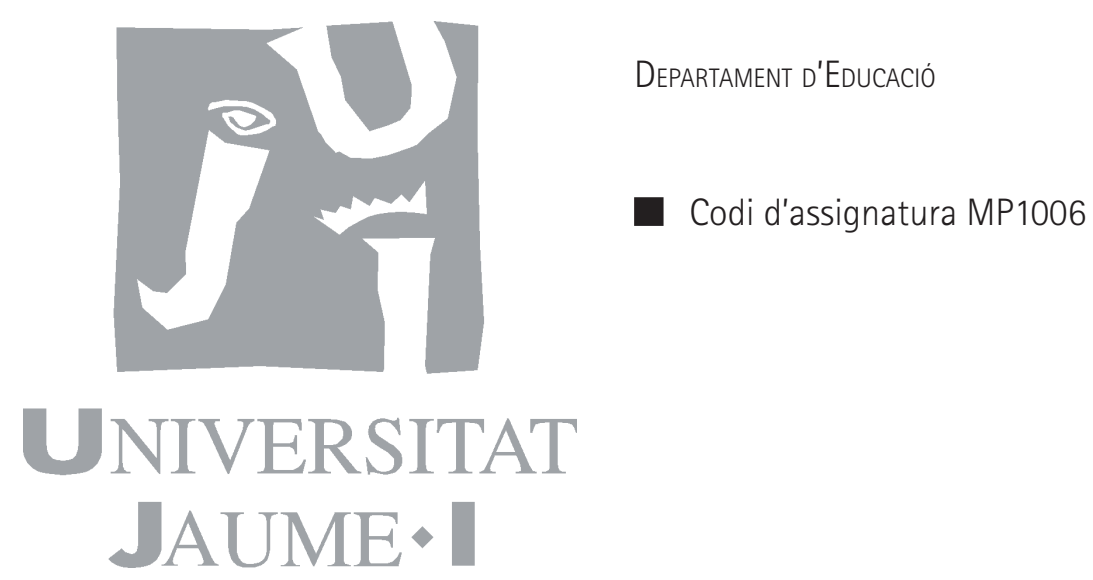


Edita: Publicacions de la Universitat Jaume I. Servei de Comunicació i Publicacions Campus del Riu Sec. Edifici Rectorat i Serveis Centrals. 12071 Castelló de la Plana http://www.tenda.uji.es e-mail: publicacions@uji.es

Col·lecció Sapientia 89. Els Nombres Naturals a l'aula de Primària http://dx.doi.org/10.6035/Sapientia89

Col-lecció Sapientia 90. Los Números Naturales en el aula de Primaria

http://dx.doi.org/10.6035/Sapientia90

www.sapientia.uji.es

Primera edició, 2014

ISBN: 978-84-695-9564-0

17 Publicacions de la Universitat Jaume I és una editorial membre de l'UNE, cosa que en garanteix la difusió de les obres en els àmbits nacional i inter-

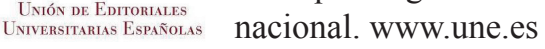

\section{(c) (i) (2)}

Reconeixement-CompartirIgual

CC BY-SA

Aquest text està subjecte a una llicència Reconeixement-CompartirIgual de Creative Commons, que permet copiar, distribuir i comunicar públicament l'obra sempre que s'especifique l'autor i el nom de la publicació fins i tot amb objectius comercials i també permet crear obres derivades, sempre que siguen distribuïdes amb aquesta mateixa llicència.

http://creativecommons.org/licenses/by-sa/3.0/legalcode 


\section{ÍNDEX}

Introducció

Tema 1. Nombres Naturals. Sistemes de numeració

1. Introducció

1.1. Reflexió sobre el concepte de nombre natural .

1.2. Usos del nombre natural

2. Formalització del conjunt de Nombres Naturals

2.1. Definició de nombre natural . .

2.2. Operacions en $N$

2.3. Ordre en $N$

3. Sistemes de numeració

3.1. Evolució històrica

3.2. Definició i tipus

3.2.1. Sistemes de numeració additius

3.2.2. Sistemes de numeració posicionals

4. Els Nombres Naturals a l'aula de Primària

4.1. Consideracions prèvies

4.2. Materials utilitzats per treballar els sistemes de numeració

4.2.1. Blocs multibase

4.2.2. Àbacs

4.2.3. Els reglets Cuisenaire

4.3. Capacitats que cal desenvolupar a l'aula de Primària . . . . . . . . .

4.4. Desenvolupament de les capacitats

Tema 2. Operacions amb Nombres Naturals

1. Introducció

2. Les operacions amb Nombres Naturals a l'aula de Primària

2.1. Fases per a l'ensenyament-aprenentatge de les operacions

2.2. Capacitats que cal desenvolupar a l'aula de Primària

2.3. Desenvolupament de les capacitats

Tema 3. Divisibilitat en Nombres Naturals

1. Introducció

1.1. De caràcter general

1.2. De caràcter específic

1.3. Posant-hi nom 
2. Múltiples i divisors dels Nombres Naturals

2.1. Definició de múltiple d'un nombre natural .

2.2. Propietats de múltiple d'un nombre natural

2.3. Definició de divisor d'un nombre natural

2.4. Propietats de divisor d'un nombre natural

3. Criteris de divisibilitat

4. Nombres primers i compostos

4.1. Nombres primers

4.2. Nombres compostos

5. Màxim comú divisor (med)

5.1. Introducció

5.2. Construcció del concepte

5.3. Automatització del concepte

6. Mínim comú múltiple $(\mathrm{mcm})$

6.1. Introducció

6.2. Construcció del concepte

6.3. Automatització del concepte

Annex

1. Formalització dels conceptes de Teoria de Conjunts

1.1. Introducció

1.2. Conjunts

1.2.1. Definicions i conceptes bàsics

1.2.2. Operacions entre conjunts

1.3. Correspondències

1.4. Relacions binàries

1.4.1. Classes d'equivalència

1.4.2. Conjunt quocient

1.5 Estructures algebraiques

Referències bibliogràfiques

Bibliografia recomanada

Índex de figures 


\section{Introducció}

Presentem en aquest document un material per a la formació inicial i permanent del professorat d'Educació Primària, on es mostren propostes didàctiques per treballar els continguts referents als Nombres Naturals en aquesta etapa educativa.

Encara que els continguts esmentats estan treballats en altres publicacions, amb aquesta pretenem oferir-los de manera unificada al lector/a en un text estructurat al voltant de les capacitats matemàtiques que cal desenvolupar en l'alumnat d'Educació Primària.

El desenvolupament dels temes compta amb una introducció que ens permet reflexionar al voltant de dues qüestions que considerem importants. L'una és l'evolució històrica dels continguts que estudiem: els Nombres Naturals i els diferents sistemes numèrics de representació, així com les operacions que es poden realitzar entre aquests nombres i les relacions que es donen entre ells. Creiem que, quan l'estudiantat de grau coneix el moment en què ha aparegut aquest concepte en la història i també com s'ha desenvolupat fins als nostres dies, hi afegeix entitat i el dota d'una perspectiva que va més enllà del treball que es fa a l'aula. L'altra és l'aspecte teòric dels conceptes treballats que s'exposa en un resum per fonamentar-los matemàticament i que parteix de la Teoria de Conjunts de G. Cantor, per tal d'apropar el lector al concepte de nombre natural de manera més intuïtiva.

A continuació, com a part més important del text i com a nucli que justifica aquesta publicació, s'inclou en cada tema un extens desenvolupament del tractament didàctic dels diferents continguts per tal de treballar-los en l'aula de Primària $i$ aconseguir, d'aquesta manera, el desenvolupament de la competència matemàtica de l'alumnat.

En l'esmentat tractament didàctic es treballen els continguts matemàtics a partir de la realitat i per a ser-hi aplicats. Com a conseqüència $i$ atorgant la importància màxima a aquesta qüestió, totes les situacions que s'enuncien acompanyant el contingut didàctic del text formen part d'altres situacions més complexes que es presenten a l'aula, en les quals els continguts matemàtics són essencials per a la seua interpretació i resolució. De vegades les activitats matemàtiques sorgiran del desenvolupament d'alguns projectes de treball globalitzats, en altres ocasions es plantejaran a partir de les necessitats que sorgeixen de les altres matèries del currículum. Sols quan es contemplen alguns continguts que no hagen aparegut en cap situació, com les esmentades abans, el mestre afavorirà de manera intencionada l'aparició de situacions que provoquen les incògnites que els portaran al descobriment dels continguts esmentats.

En tots els casos, partirem de les idees prèvies de l'alumnat sobre cadascun dels conceptes a treballar $i$, en particular, de les seues propostes personals i emergents de resolució de les diferents situacions que es plantegen. Procedirem més enda- 
vant a la recerca dels procediments generals de representació numèrica $\mathrm{i}$ de càlcul amb nombres naturals, com a forma d'oferir-los les eines matemàtiques que socialment s'utilitzen per representar aquests nombres i les diferents activitats en què intervenen.

Potser és en aquest punt on la nostra publicació va més enllà que d'altres ja existents, per oferir els passos ordenats i estructurats que justifiquen i fonamenten matemàticament tots els algorismes de les operacions elementals i que són desconeguts per a molts estudiants del Grau en Mestre (com hem pogut comprovar a través de la nostra experiència de molts anys en la docència en aquesta titulació). Aquests passos falten, en moltes ocasions, en publicacions que presenten l'inici del treball matemàtic en el plantejament d'alguns casos concrets amb xiquets i xiquetes, però no avancen fins a la culminació matemàtica dels continguts.

Atenent les recomanacions del Parlament Europeu i del Consell d'Europa sobre les competències clau per a l'aprenentatge permanent, entenem que la competència matemàtica sols es concreta i cobra sentit en la mesura que els elements i els raonaments matemàtics que s'estudien són utilitzats per enfrontar-se a aquelles situacions quotidianes que els necessiten. Per això, el seu desenvolupament a l'escola s'aconseguirà partint d'una àmplia varietat d'activitats reals, derivades d'altres camps del coneixement, de les situacions habituals que es donen a l'aula i de les pròpies experiències $i$ vivències de l'alumnat. Es tracta, en definitiva, d'aconseguir que els xiquets $i$ les xiquetes sàpiguen aplicar les destreses i les actituds que els permetran raonar matemàticament, comprendre una argumentació matemàtica, i expressar-se i comunicar-se en el llenguatge matemàtic per donar una millor resposta a les situacions de la vida de diferent nivell de complexitat.

L'objectiu del material és proporcionar una eina per als professionals de la docència i per a l'estudiantat del Grau en Mestre, que els ajude a reflexionar sobre els fenòmens educatius que ocorren a l'aula escolar i els permeta enfrontar-s'hi des d'un plantejament que considera l'ensenyament-aprenentatge de les Matemàtiques com una tasca interdisciplinària i globalitzadora que parteix d'una concepció sociocultural de l'educació en general i de l'educació matemàtica en particular.

Cal indicar que les orientacions didàctiques, a dintre de cada capacitat, estan organitzades per cicles i no per cursos independents, perquè des del punt de vista del desenvolupament cognitiu de l'alumnat és així com cal considerar l'adquisició dels coneixements en aquest etapa educativa (NCTM, 2003).

Pressuposem que a les aules de Primària on es treballen els continguts d'aquest document, es troben els materials estructurats que descriurem més endavant o d'altres semblants ideats i fabricats pels docents i/o l'alumnat, que hauran de compartir en la seua essència allò que és fonamental per a la construcció dels continguts matemàtics que es persegueixen en aquesta publicació. Aquests materials constitueixen un suport imprescindible per al treball a l'aula referent a la construcció dels Nombres Naturals i a les operacions que s'hi treballen. 
Aquest document no esgota l'activitat que el mestre ha de realitzar a l'aula. La infinitat de possibilitats de dispositius didàctics que pot oferir a l'alumnat és impossible de reflectir en qualsevol publicació. El nostre interès és posar l'atenció en el que ha de treballar per fonamentar matemàticament els procediments emprats per l'alumnat i donar indicacions de com ha de fer-ho. Mai esgotarem la creativitat didàctica que un docent ha de tenir en la seua tasca diària.

En finalitzar els tres temes comentats, s'inclou un annex que tanca aquesta publicació, en el qual es recullen alguns conceptes bàsics de la Teoria de Conjunts, necessaris per fonamentar els continguts referents als Nombres Naturals que es treballen al llibre. S'ofereix aquest annex com una guia consultiva per al lector interessat, que li permeta ampliar els seus coneixements, entenent que no són objecte d'estudi obligatori a les aules de formació inicial dels mestres. 


\section{TEMA 1}

\section{Nombres Naturals. \\ Sistemes de numeració}

\section{Introducció}

En aquest tema es treballa la construcció del concepte de nombre natural a partir de la Teoria de Conjunts i la del sistema de numeració decimal a partir de la idea de base i dels diferents ordres d'unitats. Comença el tema amb una reflexió inicial sobre el concepte de nombre natural, continua amb una formalització d'aquest, l'evolució de la seua representació mitjançant les seues representacions i un extens tractament didàctic de com treballar a l'aula de Primària aquests continguts.

\subsection{Reflexió sobre el concepte de nombre natural}

Si la pregunta que ens feren és si sabem què és un nombre, tothom podria afirmar que, efectivament, sap què és un nombre. Si més no, també ens podríem atrevir a explicar-ho, però a l'hora de definir-ho clarament, comencen les dificultats (Gómez, 1988).

Hi ha moltes definicions que proporcionen el concepte de nombre, però cap d'aquestes és totalment independent:

- Entitat abstracta que representa una quantitat especifica.

- Símbols que s'utilitzen per representar els nombres: numerals.

- Elements que formen els sistemes numèrics.

El concepte de nombre varia d'una persona a una altra, segons l'edat i la formació. Per als xiquets i xiquetes indica quantitats o ubicacions (cardinal i ordinal respectivament), o també els símbols per representar-les.

Tornant a la pregunta, què és un nombre?, trobaríem possibles respostes, per exemple a la pregunta, què és el nombre u?: $\bullet, 1$, so del nom.

Analitzant:

- referent intuïtiu, una marca, un símbol, un punt... indicarà una unitat, una sola cosa. Per representar el dos, caldrien dos símbols com aquest: 
- 1 , signe o guarisme que en la nostra societat indica una unitat, una sola cosa. Amb aquest signe se simbolitzen quantitats, s'opera... L'única intuïció és que és un únic símbol per a 1'1; però el 2, també és un símbol, mentre que la quantitat que representa és dos; el mateix passaria amb 3... Aleshores, és una representació abstracta.

- $u$, nom escrit que en la nostra llengua indica una unitat, una sola cosa. Amb aquesta es parla, s'escriu o es llig. No s'opera. No és intuïtiu a priori, perquè utilitza un símbol o lletra (castellà: uno, paraula amb tres lletres; anglès: one, també tres lletres; català: $u$ o un, una o dues lletres...).

- so del nom, s'ha d'identificar una paraula concreta amb una quantitat, i aquest so també és diferent segons l'idioma amb el qual es parle.

Els infants, en el període de 2n cicle d'Educació Infantil (3-6 anys), utilitzen processos d'identificació de la quantitat. Al principi potser no saben què representa un nombre ni com és la xifra, però saben si tenen més o menys objectes per jugar que el company, perquè la idea de quantitat és intuïtiva.

Per tant, quin és el procés d'introducció dels nombres? Com en molts altres moments de l'ensenyament, aquest és un procés en espiral, al qual es pot accedir des de diferents punts. La nostra societat està envoltada de xifres, de nombres, de paraules que signifiquen nombres, i quan parlem utilitzem els nombres indiscriminadament. Per tant, en el mateix aprenentatge natural del xiquet, apareixen nombres. A l'escola, es començarà per allò que és més intuïtiu, com ara agrupacions d'elements que indiquen la quantitat a la qual s'aniran associant a poc a poc els noms dels nombres. L'1 es referirà a un objecte, el 2, a dos objectes i així successivament. Posteriorment s'introduiran les xifres i en una fase posterior, els noms escrits.

En el 2n cicle d'Educació Infantil, s'introdueix de 1'1 al 9. A més del contacte amb els nombres que l'alumnat tindrà a partir de les seues experiències en la realitat, es poden utilitzar alguns materials didàctics com a ajuda (figures 1, 2, 3 i 4).

En la figura 1, es mostra un material anomenat Anelles de colors (fabricat per Goula) que consta d'una base de fusta amb uns pilars fixos, d'anelles de colors que s'han de col·locar als pilars i d'unes fitxes quadrades on apareixen els nombres representats per quantitats de punts en uns casos i per xifres en altres. Segons el moment en el qual es trobe el xiquet, podrem utilitzar només els punts, els punts i les xifres o només les xifres per associar-los amb les anelles.

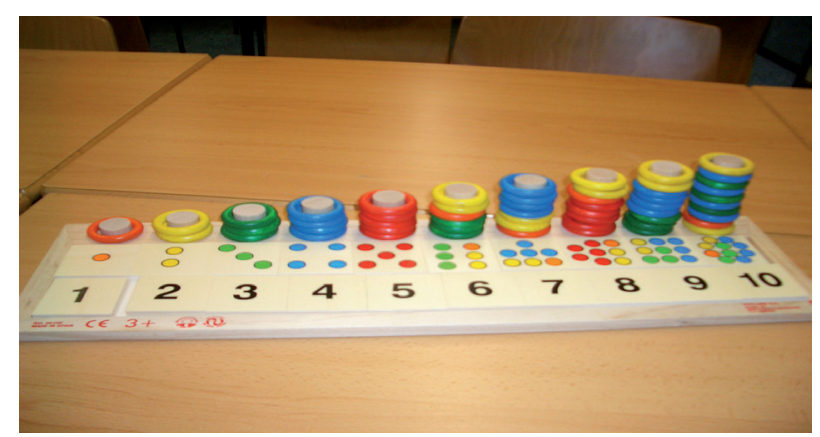



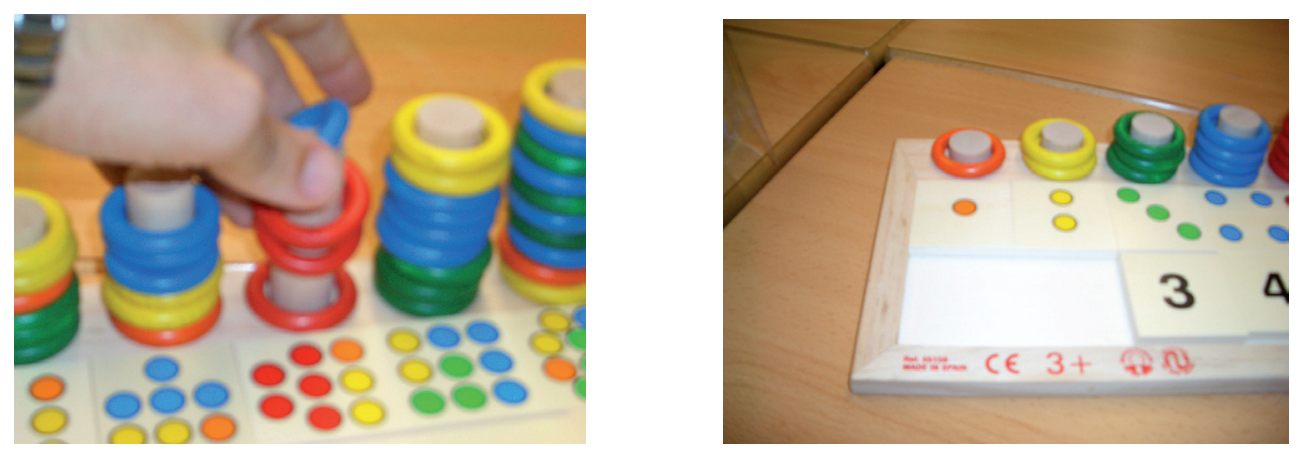

Figura 1. Imatges del material Anelles de colors

És molt evident que no necessita gaire psicomotricitat fina. Per contra, no duu els noms dels nombres escrits i, com que els pilars són fixos i la seua alçada és la que correspon a la quantitat d'anelles que cal posar, els xiquets poden omplir-los amb anelles sense reflexionar molt si és el nombre correcte d'unitats. Si volem comprovar que coneixen bé els nombres, podem alterar la posició de les fitxes quadrades associant-les amb pilars que no els correspon.

Un altre material, anomenat Aprenc a comptar (fabricat per Lado), és el que es descriu a continuació. Està format per fitxes de plàstic de dos colors que tenen impresa la grafia o el nom dels nombres de l'1 al 10, varetes de plàstic de deu longituds diferents adaptades a les quantitats i boles de colors que s'enfilen en cadascuna. En aquest material (figures 2, 3 i 4), totes les peces estan soltes, i es pot muntar com un trencaclosques.
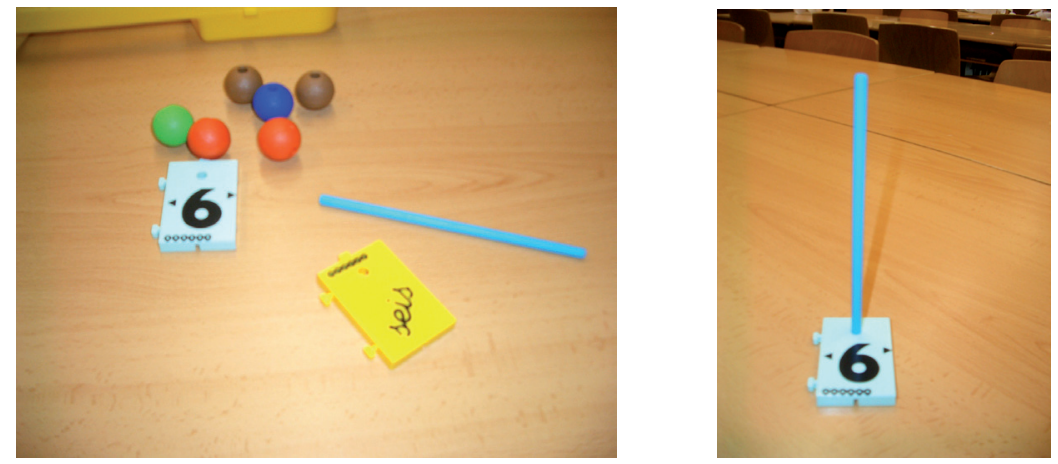

Figura 2. Imatges del material Aprenc a comptar (a)

Per utilitzar aquest material, cal tenir una certa psicomotricitat fina, perquè totes les peces han de ser col-locades al lloc i el forat de les boles no és gaire gran (això no passa en el material anterior), (figura 3). 

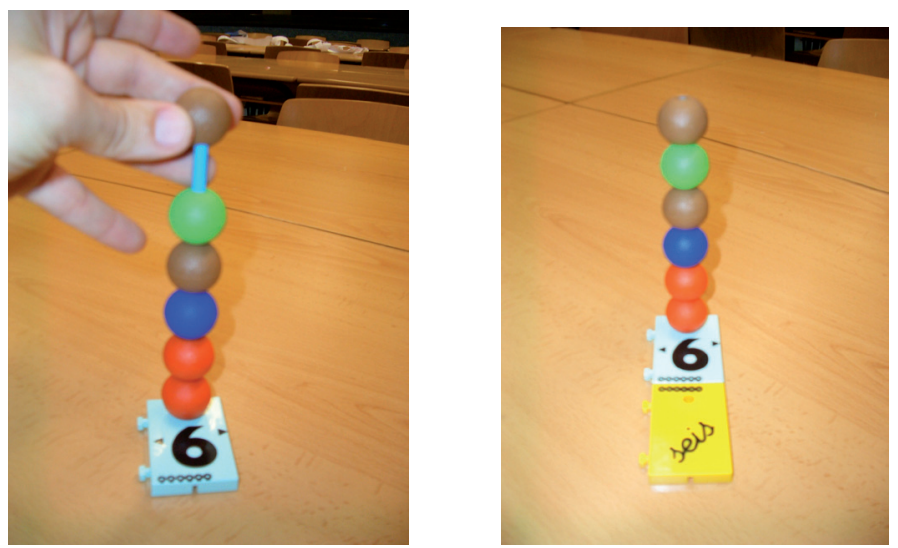

Figura 3. Imatges del material Aprenc a comptar $(b)$

Al principi cada vareta s'emparellarà amb el seu nombre corresponent i més endavant les col-locarem de manera desordenada per comprovar si coneixen realment els nombres treballats. Segons el moment evolutiu, s'hi pot afegir el nom escrit o no (figura 4).
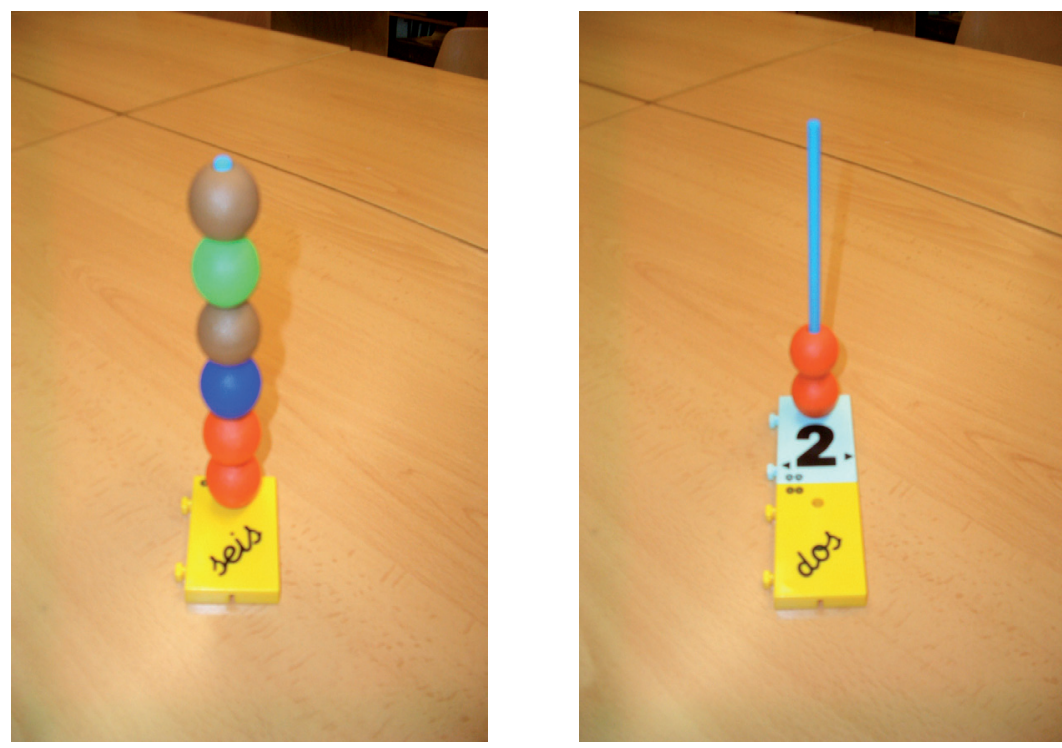

Figura 4. Imatges del material Aprenc a comptar (c)

\subsection{Usos del nombre natural}

Els nombres naturals són $\mathbb{N}: 0,1,2,3, \ldots$, i els utilitzem:

- Per comptar: 5 xiquets en un grup de treball, 3 personatges en un conte...

- Per ordenar: la 1a planta de l'escola, el 3r alumne que arriba a classe...

- Per mesurar: $84 \mathrm{~cm}$ d'alçada, el gerro fa 4 gots de suc...

- Per operar: 3 nens i 4 nenes fan 7 alumnes, menge 2 galetes de 5 i en queden 3...

- Per identificar o codificar: el telèfon de l'Us és 964728 000, l'aula 1117... 
Hi ha funcions que el nen ja té integrades abans de saber comptar, perquè són intuïtives. Aquestes funcions (Gómez, 1888) i el treball que realitzarem amb objectes de l'entorn ens permetran aconseguir que l'alumnat arribe a considerar el nombre natural com a cardinal i com a ordinal. Cardinal en el sentit de comptar una quantitat d'objectes i ordinal en el sentit d'ordenar-los.

La definició actual de nombre que inclou aquests dos aspectes es basa en la intuïció i està relacionada íntimament amb els conceptes de conjunt i quantitat d'elements d'un conjunt. Aquesta formalització de la idea de nombre no ha estat present sempre al llarg de la història i no apareix fins al segle XIX quan G. Cantor defineix formalment els conjunts numèrics, el primer dels quals és el dels nombres naturals. N'hi ha altres definicions, com ara l'axiomàtica de Peano, però ens centrarem en la de Cantor per estar més a prop de la ment de l'alumnat escolar.

\section{Formalització del conjunt dels Nombres Naturals}

Com a pas previ al treball didàctic $\mathrm{i}$ el desenvolupament professional del docent a l'aula, considerem necessari incloure les bases formals de la construcció del conjunt dels Nombres Naturals, perquè estiguen a l'abast de qualsevol lector que les vulga consultar. Òbviament aquest tractament formal de la construcció dels nombres no s'ha de realitzar en l'aula de Primària.

\subsection{Definició de nombre natural}

D'acord amb els conceptes sobre Teoria de Conjunts tractats a l'annex, es desenvolupa a continuació la construcció del conjunt dels Nombres Naturals.

Considerem un conjunt $X$ format per tots el conjunts finits existents, definim la següent relació binària entre els seus elements: si $A$ i $B$ són dos conjunts finits arbitraris que pertanyen a $X$, direm que són coordinables, equipotents o equipol·lents $(A R B)$ si i sols si existeix una aplicació bijectiva entre ells.

Aquesta és una relació binària d'equivalència perquè compleix les propietats següents:

- Entre un conjunt i ell mateix sempre existeix la identitat com a aplicació bijectiva ( $A R A$; propietat reflexiva).

- Si entre els conjunts $A$ i $B$ existeix una aplicació bijectiva $f$, la seua inversa $f^{-1}$ és una aplicació bijectiva entre $B$ i $A$ ( $A R B \rightarrow B R A$; propietat simètrica). 
- Si entre els conjunts $A$ i $B$ existeix una aplicació bijectiva $f$, i al mateix temps entre els conjunts $B$ i $C$ existeix una altra bijecció $g$, entre els conjunts $A$ i $C$ queda també definida una bijecció per la composició de les aplicacions $f$ i $g$ anteriors ( $A R B$ i $B R C \rightarrow A R C$; propietat transitiva).

Per ser una relació d'equivalència, origina una classificació dels elements de $X$ en classes d'equivalència. La propietat comuna de tots els conjunts finits d'una classe d'equivalència determinada per aquesta relació d'equipotència rep el nom de nombre natural.

Però, com es pot concretar aquesta propietat comuna? L'existència d'una aplicació bijectiva entre $A$ i $B$ ens indica que cada element del conjunt inicial $(A)$ rep en el conjunt final $(B)$ una imatge o element amb el qual es correspon de manera única, i cada element del conjunt final s'associa també de manera única amb un element del conjunt inicial (figura 5).

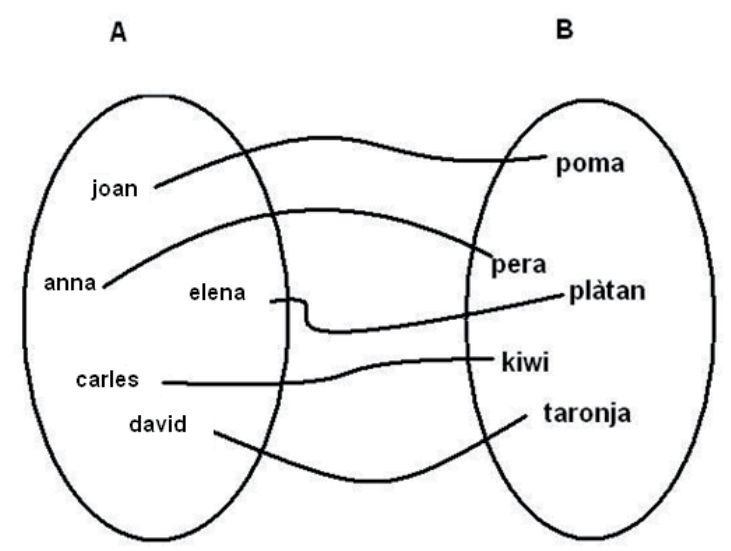

Figura 5. Aplicació bijectiva

Aquesta associació un a un dels elements dels dos conjunts ens assegura que els conjunts coordinables, equipotents o equipol-lents, per ser bijectius, tenen el mateix cardinal i, per tant, serà el cardinal comú la propietat que estàvem buscant i la que caracteritza tots els conjunts finits d'una mateixa classe d'equivalència. Així, el zero representa la classe d'equivalència dels conjunts buits, el nombre $u$ la classe d'equivalència dels conjunts equipotents, per exemple, al conjunt $\mathrm{A}=\{\mathrm{el} \mathrm{Sol}\}$ (si ens permetem usar un en la definició d'u, es pot redactar: el nombre u representa la classe d'equivalència dels conjunts amb un element), el dos representaria tots els conjunts equipotents, per exemple, al conjunt $\mathrm{A}=\{$ la Terra, la Lluna $\}$ (si acceptem usar dos en la definició del dos, es pot redactar: el nombre dos representa la classe d'equivalència dels conjunts amb dos elements), etc. En general, un conjunt $A$ pertany a la classe del nombre natural $m$ si $\operatorname{card}(A)=m$.

Una vegada queda clar que tots els conjunts equipotents, coordinables o equipollents tenen el mateix cardinal, amb un que utilitzem per representar-los tots ens bastaria. És a dir, tots els conjunts amb 5 elements contenen la mateixa informació 
pel que fa al cardinal; per tant, amb un conjunt que els represente, n'hi ha prou. Ocorre el mateix per a tots els nombres naturals i, per tant, amb un sol conjunt finit podem representar qualsevol d'aquests nombres.

\subsection{Operacions en $N$}

Siguen $a$ i $b$ dos nombres naturals, i $A$ i $B$ dos conjunts finits, arbitraris i disjunts, de manera que $a=\operatorname{card}(A)$ i $b=\operatorname{card}(B)$. Es defineix l'Addició de $a$ i $b$, com el cardinal de la unió de $A$ i $B$. És a dir:

$\forall a, b \in N \wedge \forall A, B \in X / a=\operatorname{card}(A), b=\operatorname{card}(B) \wedge A \cap B=\Phi: a+b=\operatorname{card}(A \cup B)$.

A partir de les propietats de les operacions entre conjunts es pot demostrar que l'addició de nombres naturals compleix les propietats següents:

- Associativa

- Commutativa

- Element neutre (0)

Per tant, el conjunt $N$ amb l'operació que s'acaba de definir $(N,+)$ té estructura de monoide commutatiu (vegeu annex).

Siguen $a$ i $b$ dos nombres naturals, i $A$ i $B$ dos conjunts finits, arbitraris, de manera que $a=\operatorname{card}(A)$ i $b=\operatorname{card}(B)$. Es defineix la multiplicació de $a$ i $b$, com el cardinal del producte cartesià de $A$ i $B$. És a dir:

$$
\forall a, b \in N \wedge \forall A, B \in X / a=\operatorname{card}(A), b=\operatorname{card}(B): a \times b=\operatorname{card}(A \times B) .
$$

A partir de les propietats de les operacions entre conjunts es pot demostrar que la multiplicació de nombres naturals compleix les propietats:

- Associativa

- Commutativa

- Element neutre (1)

Així doncs, el conjunt $N$ amb l'operació que s'acaba de definir, $(N, \times)$, té estructura de monoide commutatiu (vegeu annex).

Com que, a més es compleix la propietat distributiva de la multiplicació respecte de l'adició, $(N,+, \times)$ té estructura de semianell commutatiu i unitari (vegeu annex). 


\subsection{Ordre en $N$}

Si en aquest conjunt definim la relació «ser menor o igual» de la manera següent:

$$
\forall a, b \in N: a \leq b \leftrightarrow \exists n \in N / a+n=b .
$$

es pot comprovar que és una relació binària d'ordre total perquè compleix les propietats següents:

- Qualsevol nombre natural sempre és menor o igual que ell mateix, perquè $\exists 0 \in N / a+0=a(a \leq a$; propietat reflexiva $)$.

- Si un nombre natural és menor o igual que un altre i a la vegada el segon és menor o igual que el primer, necessàriament ambdós nombres són iguals. És a dir,

$\forall a, b \in N / a \leq b \wedge b \leq a \rightarrow \exists n \in N / a+n=b \wedge \exists m \in N / b+m=a \rightarrow(b+m)+n=b$

$\rightarrow m+n=0 \rightarrow m=0=n \rightarrow a=b(a \leq b \wedge b \leq a \rightarrow a=b$; propietat antisimètrica $)$.

- Si un nombre natural és menor o igual que un altre i a la vegada aquest és menor o igual que un tercer, aleshores el primer és menor o igual que el tercer. És a dir:

$\forall a, b, c \in N / a \leq b \wedge b \leq c \rightarrow \exists n \in N / a+n=b \wedge \exists m \in N / b+m=c \rightarrow(a+n)+m=c$

$\rightarrow a+(n+m)=c \rightarrow a \leq c(a \leq b \wedge b \leq c \rightarrow a \leq c ;$ propietat transitiva $)$.

- Donats dos nombres naturals qualssevol, o el primer és menor o igual que el segon o el segon és menor o igual que el primer. És a dir, $\forall a, b \in N: a \leq b \vee b \leq a$. Per demostrar aquesta propietat haurem de contemplar dos casos:

1. Si $a=b$, és evident que $a \leq b \vee b \leq a$

2. Si $a \neq b$, existirà sempre un altre nombre natural que sumat a un d'aquests donarà com a resultat l'altre, és a dir:

$\exists n \in N / a+n=b \vee b+n=a \rightarrow a \leq b \vee b \leq a$ (propietat connexa).

Direm aleshores que $N$, amb la relació anterior, $(N,+, \times, \leq)$, és un semianell commutatiu i unitari totalment ordenat i no hi haurà cap dubte a l'hora d'establir si un nombre natural és major, menor o igual que un altre (vegeu annex).

Encara que hem definit la relació d'ordre «ser menor o igual» amb el símbol $\leq$, es podria definir de manera semblant la relació «ser major o igual» amb el símbol $\geq$. En qualsevol dels casos, si eliminem la possibilitat d'igualtat entre els nombres, les relacions definides es converteixen en altres d'ordre estricte que s'anomenen ser menor estrictament o ser major estrictament i es representen amb els símbols $<\mathrm{i}>$, respectivament. 
En aquest moment comencen a tenir més sentit les paraules cardinal i ordinal. L'aspecte cardinal del nombre natural serà el que es refereix a les quantitats, és a dir, als cardinals dels conjunts i l'ordinal serà el que designa l'ordre i estableix comparacions entre els cardinals dels conjunts en ordenar-los.

\section{Sistemes de numeració}

\subsection{Evolució històrica}

No sabem amb seguretat quan va començar l'ésser humà a necessitar un sistema d'escriptura de nombres, és a dir, un sistema de numeració, però sembla segur que uns dels primers instruments utilitzats per comptar van ser els dits de la mà (Ifrah, 2001). Això implicaria que les primeres representacions numèriques es feren agafant com a referent el cinc i, posteriorment, es referiren al deu pel fet que es podien utilitzar els dits d'ambdues mans. Sembla que la humanitat usava el deu com a referent quan el llenguatge parlat es va consolidar. Si més no, és el que podem deduir, en l'àmbit indoeuropeu, del nostre sistema numèric i del nom d'alguns nombres, com ara deu, en llatí decem; onze, en llatí undecim (un més deu); dotze, en llatí duodecim (dos més deu). Fins i tot es podria pensar en una base vint, tot comptant els dits dels peus i les mans (en llatí, viginti).

No obstant això, quan va créixer la necessitat de representar nombres més grans, era possible escriure grups de cinc ratlles (IIIII) fins a arribar a la quantitat que es volia. Un exemple d'aquest mètode és un os de llop trobat a la República Txeca, on apareixen 55 incisions bastant profundes dividides en grups de cinc. Aquest os té uns 35.000 anys d'edat aproximadament. No cal dir que aquest sistema (de representació simple) primitiu i antic no constituïa una eina eficaç per a un càlcul desenvolupat.

A partir del III mil·leni a. C., els egipcis van utilitzar un sistema numèric (d'agrupament múltiple) procedent de la seua escriptura jeroglífica. Aquest sistema de base 10 utilitzava signes diferents per a les unitats, les desenes, centenes, etc. En la figura 6 , es veu com una determinada potència de deu podia tenir representacions gràfiques molt paregudes però no idèntiques.

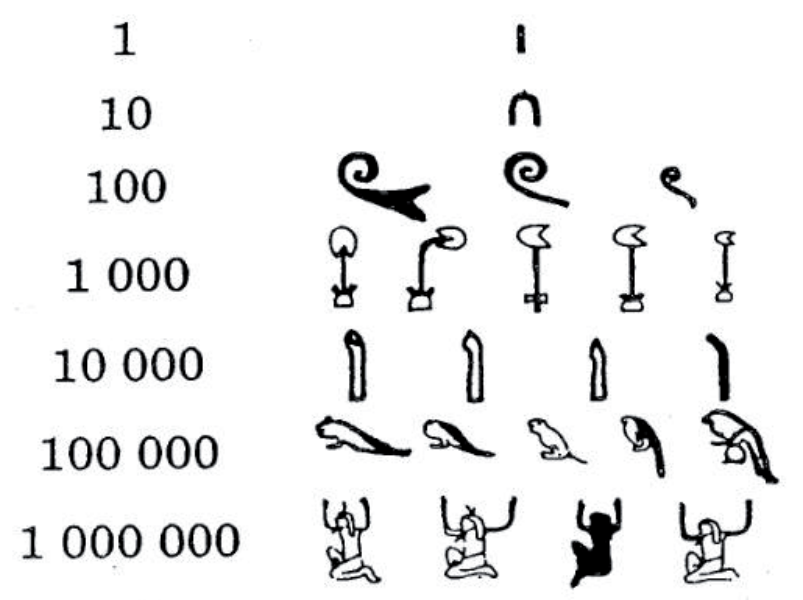

Figura 6. Xifres en l'escriptura jeroglífica egípcia (Ifrah, 1988) 
Permetia escriure nombres grans i oferia una gran innovació respecte als antics sistemes. Cal dir, però, que el procediment de composició consistia a repetir els símbols de la mateixa manera que l'home primitiu repetia les ratlles. En l'escriptura jeroglífica s'escrivia indistintament d'esquerra a dreta o de dreta a esquerra. Els signes numèrics modificaven la seua orientació en funció d'aquests sentits d'escriptura. A la figura 7, on es representa el 2.425, es veu com l'orientació dels símbols és diferent a la de la figura 6.

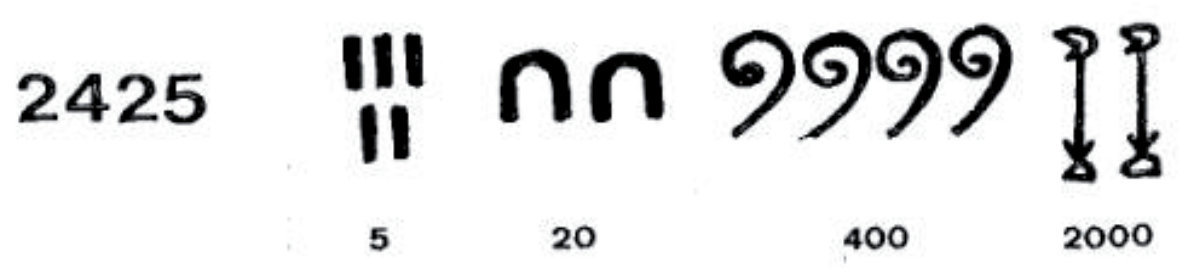

Figura 7. Escriptura jeroglífica del nombre 2.425 (Ifrah, 1988)

Els mateixos egipcis, poc després, van utilitzar un sistema de numeració més modern i més pràctic relacionat amb l'escriptura hieràtica. El sistema continuava sent decimal, però no era necessari repetir constantment els caràcters, sinó que se n'havien introduits uns quants de nous que indicaven quantes vegades es repetia cada símbol (sistema d'agrupament multiplicatiu).

Aquest canvi que trobem en el papir Rhind (segle XVII a.C.), també anomenat d'Ahmes, conservat al British Museum de Londres, ens mostra un aspecte que havia de ser fonamental per als nostres sistemes de numeració: la no-necessitat de repetir els símbols.

El sistema de numeració que utilitzaven els grecs al voltant del 600 a. C., concretament els atenesos, xifrava les quantitats amb la primera lletra del nom del nombre corresponent, era un sistema acrofònic. Les unitats fins al 4 es representaven per ratlles, el 5 es representava per la lletra PI majúscula per ser PENTE el nom grec d'aquesta quantitat, per al 10 s'utilitzava la lletra DELTA majúscula per ser DEKA el nom d'aquest nombre, etc. També es van crear símbols mixtos a partir del cinc: si s'hi afegia el símbol del deu inscrit simbolitzava el 50, si era el del cent, 500, si el del mil, 5.000 (figura 8). 


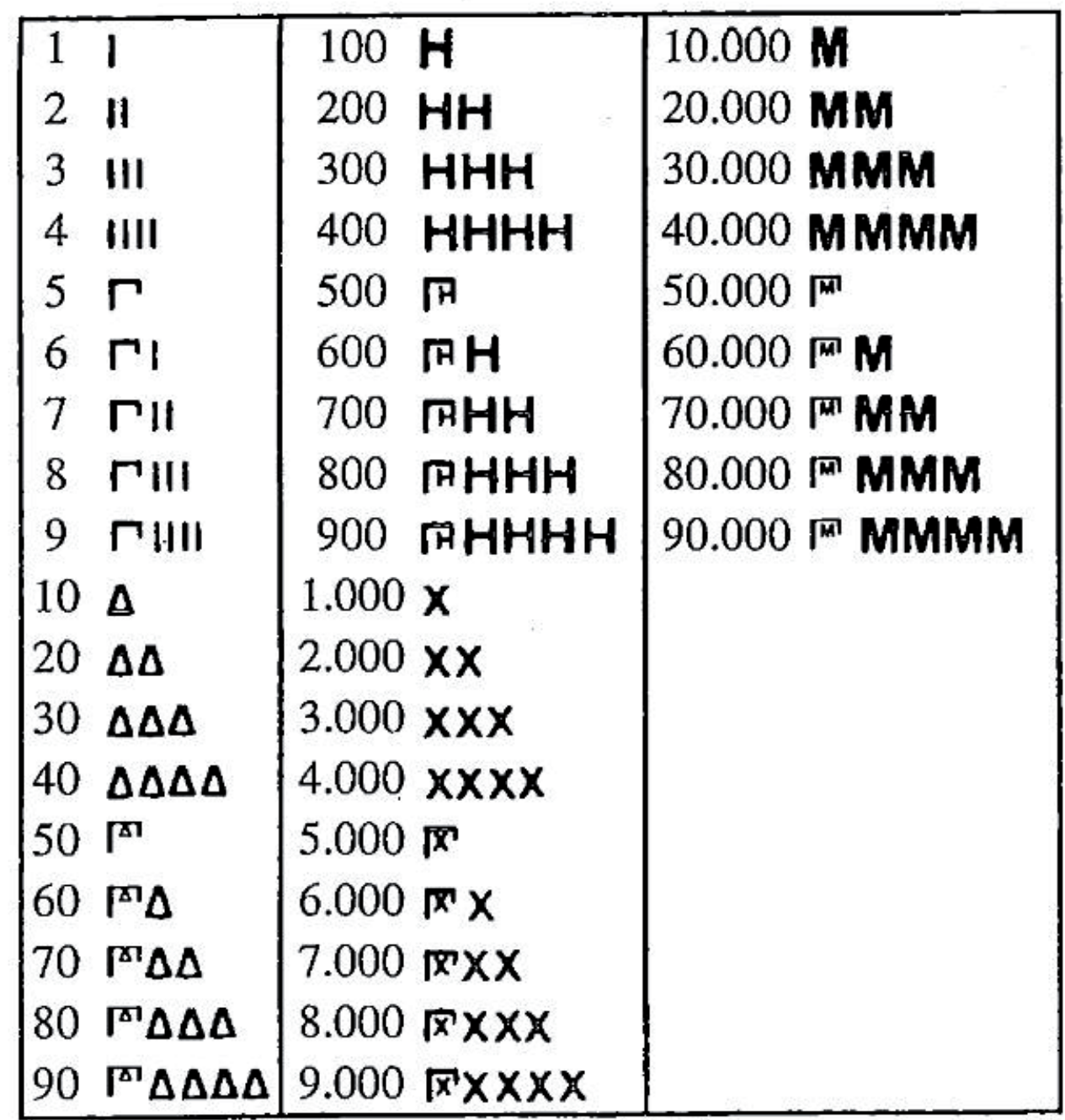

Figura 8. Representacions numèriques en l'escriptura acrofònica grega (Ifrah, 1988)

En la figura 9 es mostra un exemple de la representació del nombre 7.699, usant les xifres de la taula anterior:

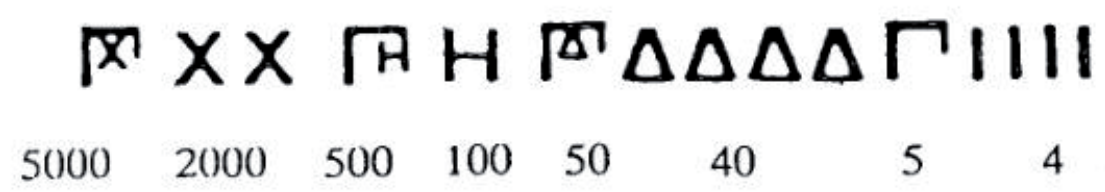

Figura 9. Escriptura acrofònica del nombre 7.699 (Ifrah, 1988)

Poc després, aquest sistema numèric va ser substituït per un altre que feia servir totes les lletres de l'alfabet grec (acompanyades d'una barra horitzontal a la part superior quan representaven nombres) i alguns altres símbols procedents de l'alfabet fenici: 


\begin{tabular}{|c|c|c|c|c|c|c|c|c|c|c|c|}
\hline A & $\alpha$ & alpha & 1. & I & $\iota$ & iota & 10 & $\mathbf{P}$ & $\rho$ & ro & 100 \\
\hline B & $\beta$ & beta & 2 & $\mathbf{K}$ & $\kappa$ & kappa & 20 & $\Sigma$ & $\sigma$ & sigma & 200 \\
\hline$\Gamma$ & $\gamma$ & gamma & 3 & $\Lambda$ & $\lambda$ & lambda & 30 & $\mathbf{T}$ & $\tau$ & tau & 300 \\
\hline$\Delta$ & $\delta$ & delta & 4 & M & $\mu$ & $\mathrm{mu}$ & 40 & $\mathbf{Y}$ & $v$ & upsilon & 400 \\
\hline $\mathbf{E}$ & $\epsilon$ & epsilon & 5 & $\mathbf{N}$ & $v$ & nu & 50 & $\Phi$ & $\phi$ & phi & 500 \\
\hline$\Sigma$ & $\sigma$ & digamma & 6 & $\Xi$ & $\xi$ & ksi & 60 & $X$ & $x$ & khi & 600 \\
\hline $\mathbf{Z}$ & $\zeta$ & dzeta & 7 & O & $\sigma$ & omicron & 70 & $\Psi$ & $\psi$ & psi & 700 \\
\hline H & $\eta$ & eta & 8 & П & $\pi$ & pi & 80 & $\mathbf{\Omega}$ & $\omega$ & omega & 800 \\
\hline$\Theta$ & $\theta$ & thêta & 9 & $G$ & 9 & qoppa & 90 & $m$ & 3 & san & 900 \\
\hline
\end{tabular}

Figura 10. Numeració alfabètica grega (Ifrah, 1988)

Amb aquest sistema es podrien xifrar els nombres que van de 1'1 al 999. Per escriure els milers, afegien una coma subscrita a la part esquerra superior de la lletra; així, una ' $\alpha$ indicava 1.000, i una 'i indicava 10.000. Amb aquest sistema es podia escriure fins al 900.999.

Tot seguint l'exemple grec, els romans van utilitzar també les lletres de l'alfabet per escriure els nombres d'acord amb els valors de la figura 11.

\begin{tabular}{|ll|ll|ll|}
\hline un & I & deu & $\mathbf{X}$ & cent & $\mathbf{C}$ \\
dos & II & vint & $\mathbf{X X}$ & dos-cents & $\mathbf{C C}$ \\
tres & III & trenta & $\mathbf{X X X}$ & tres-cents & $\mathbf{C C C}$ \\
quatre & IV & quaranta & $\mathbf{X L}$ & quatre-cents & $\mathbf{C D}$ \\
cinc & $\mathbf{V}$ & cinquanta & $\mathbf{L}$ & cinc-cents & $\mathbf{D}$ \\
sis & VI & seixanta & $\mathbf{L X}$ & sis-cents & $\mathbf{D C}$ \\
set & VII & setanta & $\mathbf{L X X}$ & set-cents & DCC \\
vuit & VIII & vuitanta & $\mathbf{L X X X}$ & vuit-cents & DCCC \\
nou & IX & noranta & $\mathbf{X C}$ & nou-cents & $\mathbf{C M}$ \\
\hline
\end{tabular}

Figura 11. Numeració romana

El principi d'equivalències era molt semblant al grec, de manera que la unitat era simbolitzada per una I, i es podia repetir al principi fins a quatre vegades IIII (4). La unitat següent era $\mathrm{V}$, que simbolitzava el 5. Més endavant es va introduir la regla segons la qual només es permet repetir qualsevol xifra fins a tres vegades. Així, per expressar el 4, es resta una unitat de la xifra següent IV (4). En general, quan dues xifres van juntes, la inferior se suma a la superior si va a la dreta (VI), i es resta si va a l'esquerra (IV), tenint en compte que les úniques xifres que resten són: I davant de V i X, X davant de L i C, i C davant de D i M (mil). Així, per exemple, el 999 s'escrivia CMXCIX.

El mecanisme més utilitzat per escriure nombres superiors al mil era posar una ratlla dalt de qualsevol símbol, que indicava que aquest s'havia de multiplicar per mil; el 2.000, per exemple, s'escrivia III, i el 10.000, X. Així, per exemple, el 3.749 s’escrivia bé MMMDCCXLIX, bé IIIDCCXLIX. 
Però el sistema de numeració més modern i pràctic va nàixer a l'Índia al voltant del segle III a. C. Conservava la base decimal i el caràcter d'agrupament multiplicatiu del sistema egipci. Cap al segle $v$ de la nostra era es va incorporar a aquest sistema un canvi fonamental respecte dels anteriors, que consistia en la introducció d'un guarisme per escriure la xifra zero, que indicava la absència d'algun ordre d'unitats en el nombre i obtingueren així un sistema de numeració on el valor de cada xifra depenia de la posició que ocupava en la representació del nombre (sistema de numeració posicional: d'agrupament multiplicatiu, amb valor posicional de les xifres i amb ús de la xifra zero).

Aquestes xifres hindús van anar estenent-se i adoptant formes diverses en diferents llengües. Els àrabs adoptaren els sistemes d'escriptura numèrica que havien après dels grecs i els hindús, i utilitzaren tots dos. Però introduïren en Occident, al voltant del segle $\mathrm{x}$, el sistema de numeració que havia de triomfar i imposar-se sobre els altres, i que va rebre el nom de numeració aràbiga o indoaràbiga, les xifres inicials de la qual eren les que es representen a la figura 12.

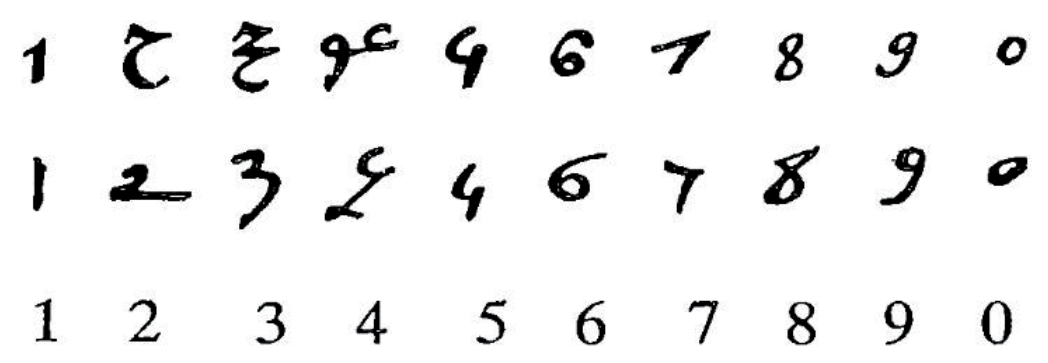

Figura 12. Xifres àrabs (Ifrah, 1988)

En el món cristià, es va adoptar aquest sistema hindú i àrab perquè oferia uns grans avantatges respecte del romà i encara que es va fer públic al segle XIII en editar-se el Liber abaci de Leonardo de Pisa Fibonacci, no es va utilitzar de manera normalitzada fins al segle Xv, en el qual la impremta va fer possible que el seu coneixement arribara a una franja de població molt més gran que al principi. Les xifres del sistema hindú han evolucionat al llarg del temps fins a arribar als nostres dies. En la figura 13 s'il-lustren els primers passos d'aquesta evolució:

\begin{tabular}{|c|c|c|c|c|c|c|c|c|c|c|}
\hline Fechas & 1 & 2 & 3 & 4 & 5 & 6 & 7 & 8 & 9 & 0 \\
\hline $\begin{array}{l}\text { siglo } \\
\text { XII }\end{array}$ & 1 & $\begin{array}{l}3 \\
3\end{array}$ & $\begin{array}{l}3 \\
3\end{array}$ & \& & $\begin{array}{l}y \\
5\end{array}$ & $\begin{array}{l}6 \\
6\end{array}$ & $\begin{array}{l}7 \\
7\end{array}$ & 8 & 9 & 0 \\
\hline $\begin{array}{l}\text { siglo } \\
\text { XIII }\end{array}$ & 1 & 7 & 3 & 8 & 4 & 6 & A & 8 & 9 & $\sigma^{\circ}$ \\
\hline $\begin{array}{l}\text { siglo } \\
\text { XIV }\end{array}$ & 2 & $z$ & 3 & 8 & 4 & 5 & 1 & 8 & 9 & 0 \\
\hline $\begin{array}{l}\text { siglo } \\
\text { XV }\end{array}$ & $\mathbb{E}$ & 2 & 3 & $\ell$ & 5 & $\sigma$ & $A$ & 8 & 9 & 8 \\
\hline $\begin{array}{l}\text { hacia } \\
1524\end{array}$ & 9 & $z$ & 3 & 2 & 5 & 6 & $\hat{\wedge}$ & 8 & 9 & - \\
\hline
\end{tabular}

Figura 13. Evolució de les xifres àrabs a Europa (Ifrah, 1988) 
Altres civilitzacions o societats han tingut sistemes de numeració diferents. Alguns exemples dels quals són: el xinès el 1500 a. C., el babilònic al segle xIII a. C. i el maia al segle XII aproximadament. Es pot trobar àmplia informació sobre aquests sistemes de numeració i altres en Ifrah 1988 i 2001.

\subsection{Definició i tipus}

Un sistema de numeració és un conjunt de normes i convenis per escriure nombres utilitzant la menor quantitat de símbols possible.

Caldrà tornar a la història, una altra vegada, per entendre qüestions importants dels sistemes de numeració, i la depuració que han patit per causes d'economia d'escriptura, de dificultat i de vegades, religioses.

Quan l'ésser humà va començar a comptar va usar els dits, pedres, marques en bastons, nusos en una corda i d'altres formes per passar d'un nombre al següent. A mesura que la quantitat creix, es fa necessari un sistema de representació més pràctic. En diferents parts del món i en èpoques diferents es va arribar a la mateixa solució; quan s'aconsegueix un determinat nombre d'unitats (de primer ordre) es fa una marca diferent, de segona classe, que les representa totes (unitats de segon ordre). Aquest nombre és la base. S'hi continuen afegint unitats fins que es torna a aconseguir per segona vegada el nombre anterior i s'hi afig una altra marca de la segona classe. I així, s'hi continuen afegint unitats de primer ordre fins a arribar a un nombre de marques de segona classe iguals a la base. Aleshores s'hi introdueix una marca diferent, de tercera classe (unitats de tercer ordre), per representar aquesta unitat. Procedint de manera semblant i de forma successiva es van construint els diferents ordres superiors d'unitats.

La base que més s'ha utilitzat al llarg de la història és la base 10, segons totes les aparences, perquè aquest és el nombre dels dits de les mans de l'ésser humà. N'hi ha alguna excepció notable, com ara la numeració babilònica, que usava 10 i 60 com a bases, i la numeració maia, que usava 20 i 5, encara que amb alguna irregularitat. Des de fa 5.000 anys, la gran majoria de les civilitzacions han comptat en unitats, desenes, centenes, milers, etc., és a dir, de la mateixa manera com continuem fent-ho avui.

No obstant això, la forma d'escriure els nombres ha estat molt diversa, i molts pobles han vist impedit el seu avanç científic per no disposar d'un sistema de numeració que permetera utilitzar uns procediments eficaços per al càlcul. Quasi tots els sistemes utilitzats representen amb exactitud els Nombres Naturals, encara que en alguns es poden confondre uns nombres amb d'altres (en el del sistema egipci d'agrupament multiplicatiu, per exemple). Molts d'aquests no són capaços de representar grans quantitats $i$ d'altres requereixen un nombre de símbols tan gran que els fa poc pràctics. A més, no permeten, en general, efectuar operacions tan senzilles com la multiplicació, i exigeixen procediments molt complicats que només estaven a l'abast d'uns pocs iniciats. Pel que fa a la divisió, és molt més 
greu, ja que no existien regles per poder fer-la. De fet, quan es va començar a utilitzar a Europa el sistema de numeració actual, els abaquistes, professionals del càlcul, es van oposar amb les raons més peregrines, entre les qual hi havia: «sent el càlcul quelcom complicat en si mateix, hauria de ser un mètode diabòlic aquell que permetera efectuar les operacions de manera tan senzilla». El sistema actual va ser inventat pels indis i transmès a Europa pels àrabs, com ja s'ha esmentat anteriorment. De l'origen indi del sistema hi ha suficients proves en documents indis i àrabs. Leonardo de Pisa (Fibonacci), va ser un dels introductors del nou sistema en l'Europa de 1202. El gran mèrit dels indis va ser la utilització del zero amb valor numèric per ocupar diferents posicions en la representació dels nombres, la qual cosa evita confusions i permet un sistema en què només deu símbols poden representar qualsevol nombre encara que siga molt gran, i simplificar la manera d'efectuar les operacions.

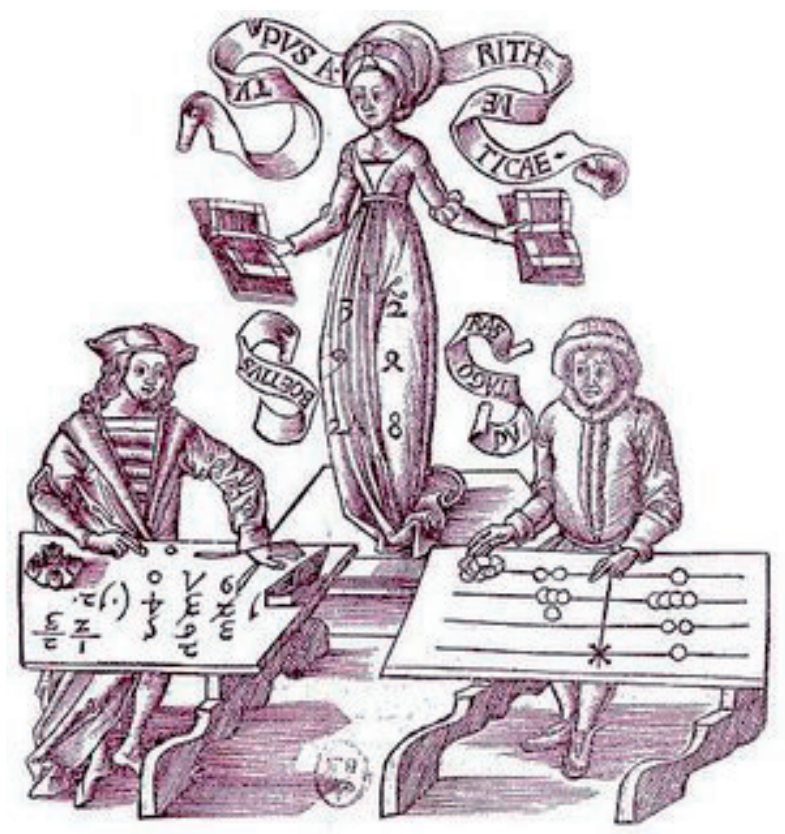

Figura 14. Gravat del començament del segle XVI que representa el triomf dels algorismes sobre els àbacs. Els algoristes, emprant les nou xifres i el zero, s'imposen als abaquistes, ja que són capaços de fer més ràpidament les operacions aritmètiques. En segon pla, la dama Aritmètica, amb un vestit guarnit de xifres, mostra amb la mirada quines són les seues preferències (Ifrah, 1988)

La introducció d'aquest sistema de numeració que ara fem servir com si haguera existit des de sempre no va ser fàcil. Tres-cents anys més tard de la seua introducció a Europa per Fibonacci, en el segle XVI, encara es feien competicions entre abaquistes, que feien servir l'àbac, i algoristes, que feien els comptes més o menys com nosaltres ara (figura 14). Els àbacs van resistir, malgrat tot, fins al segle xx, quan encara es podien trobar als bancs, comerços, etc. 


\subsubsection{Sistemes de numeració additius}

Per veure com funciona la representació numèrica en un sistema additiu, considerem el sistema jeroglífic egipci. Per cada unitat s'escriu un traç vertical, per cada desena, un símbol en forma d'arc i per cada centena, miler, desena i centena de miler i milió, un jeroglífic específic. Així, per escriure 754 feien servir 7 jeroglífics de centenes, 5 de desenes i 4 traços. D'alguna manera, totes les unitats estan físicament presents.

Els sistemes additius són aquells que acumulen els símbols de totes les unitats, desenes..., necessaris fins a completar el nombre. Una de les seues característiques és, per tant, que es poden posar els símbols en qualsevol ordre, encara que, en general, és preferible una disposició determinada. Cada xifra té un valor propi que no depèn del lloc que ocupa i es diuen additius perquè, per conèixer el nombre, s'ha de fer una addició. Com ja s'ha comentat, les dificultats de representar nombres grans, i les complicacions que hi havia a l'hora d'operar, feren que no prosperara.

\subsubsection{Sistemes de numeració posicionals}

Aquests sistemes utilitzen el principi del valor relatiu; és a dir, cada xifra representa valors diferents depenent de la posició que ocupe en l'expressió del nombre. L'exemple per excel·lència seria el sistema de numeració decimal (a partir d'ara $\mathrm{SND}$ ), però n'hi ha d'altres que també s'utilitzen i que s'explicaran més endavant.

La base (vegeu 3.2) suposa un punt d'inflexió en la col·locació de les xifres. És a dir, si un sistema de numeració posicional té base $b$ significa que $b$ unitats de qualsevol ordre formen una unitat d'ordre immediat superior. La base representa també la quantitat de xifres que el sistema utilitza, és a dir, $b$ és el nombre de símbols diferents permesos en un sistema de numeració posicional per escriure els nombres.

En el cas de l'sND, la base seria el 10 i utilitza com a xifres $0,1,2,3, \ldots, 9$.

Analitzem l'sND. Per representar quantitats inferiors a 10, unitats de primer ordre o unitats, s'utilitza una sola xifra.

En arribar a la base, és a dir, la quantitat que s'obté en afegir 1 al 9, el sistema utilitza el criteri posicional i necessita dues xifres per representar el nombre en el qual hi ha un grup i cap unitat solta. Cadascun d'aquests grups formats per 10 unitats s'anomena desena o unitats de segon ordre. Per indicar dotze, per exemple, s'escriu 12. Utilitzem dues xifres: la que s'escriu més a l'esquerra, l'1, és la xifra de les desenes, mentre que el 2 és la xifra de les unitats. Però en el fons estem escrivint:

$$
\mathbf{1} \times 10+\mathbf{2}=\mathbf{1 2}
$$


Agafant un altre exemple, $72: 7 \times 10+\mathbf{2}=\mathbf{7 2}$.

De la mateixa manera, en passar el graó següent, la centena, s'ha de recórrer a una nova posició a l'esquerra de les anteriors, per escriure xifres que indiquen grups de deu desenes, per exemple $325: \mathbf{3} \times 100+\mathbf{2} \times 10+\mathbf{5}=\mathbf{3 2 5}$. I així successivament.

N'hi podríem posar molts exemples, 8.795: $8 \times 1.000+\mathbf{7} \times 100+\mathbf{9} \times 10+\mathbf{5}=$ 8.795.

Si la quantitat és molt gran, representem l'u seguit de zeros, utilitzant potències de 10:

$$
\mathbf{9} \times 10^{6}+\mathbf{6} \times 10^{5}+\mathbf{5} \times 10^{3}+\mathbf{3} \times 10+\mathbf{2}=\mathbf{9 . 6 0 5 . 0 3 2} .
$$

Aquesta manera de representar els nombres s'anomena descomposició polinòmi$c a$. Cal notar que quan en un nombre no existeixen unitats d'un determinat ordre, es col-loca un zero en la posició corresponent, però, en la descomposició polinòmica, no apareix. Simplement, a l'exemple anterior, els sumands que representarien $\mathbf{0} \times 10^{4} \mathrm{o} \mathbf{0} \times 10^{2}$, s'obvien.

A les unitats no cal posar potència de 10 , perquè seria amb exponent 0 , ja que $10^{0}=1$. Tampoc cal explicitar l'exponent de la potència $10^{1}$; per tant, $25=2 \times 10^{1}+$ $+5 \times 10^{0}$ ho escrivim $25=2 \times 10+5$.

El funcionament de l'SND es reprodueix en cada sistema posicional siga aquest de la base que siga, exceptuant la utilització del punt o qualsevol altra marca per separar els blocs de tres xifres, els noms de les diferents ordres d'unitats (és a dir, unitats, desenes, centenes..., queda reservat únicament pel SND) i la manera de llegir els nombres (per exemple, 132 es llig «cent trenta-dos», mentre que $132_{\text {(4 }}$ es llig «u, tres, dos en base quatre»).

Si utilitzem diferents sistemes de numeració per representar un nombre obtenim diverses expressions per a ell que s'anomenen numerals. Així, per exemple: 7, 21 ${ }_{3}$, VII... són numerals que corresponen a la quantitat de dies d'una setmana. Com que generalment el treball amb nombres i operacions es fa referit a un sol sistema de numeració, s'assimila la paraula numeral a la paraula nombre i s'utilitzen indistintament.

Desenvolupem a continuació alguns exemples de sistemes posicionals en altres bases.

\section{Sistema de numeració en base 5}

És un sistema que s'ha utilitzat al llarg de la història pel fet que 5 és el nombre dels dits d'una mà. Utilitza les xifres $0,1,2,3$ i 4, i es canvia d'ordre d'unitats, afegint una xifra a l'esquerra del numeral, quan s'arriba a un agrupament de cinc unitats de qualsevol ordre (per la qual cosa mai ha d'aparèixer el valor de la base entre les xifres d'un nombre, ni cap superior a ella). 
Quan tenim expressada una quantitat en base 5, podem saber el numeral que li correspon en l'SND a partir d'unes senzilles operacions d'addició i multiplicació. Suposem que el nombre, escrit en base 5, és $23401_{(5}$. Si volem saber quin és el seu valor en l'SND, caldrà desenvolupar-ne la descomposició polinòmica en la base 5 , i realitzar les operacions que s'hi indiquen:

$\mathbf{2 3 . 4 0 1}_{(5}=2 \times 5^{4}+3 \times 5^{3}+4 \times 5^{2}+1=2 \times 625+3 \times 125+4 \times 25+1=\mathbf{1 . 7 2 6}$.

El paper de les potències de 10 en l'snd, en aquest moment, el fan les potències de 5 .

Recíprocament, també es pot passar un numeral expressat en l'SND a un sistema de base 5. Utilitzant els mateixos nombres d'abans, suposem que volem escriure en base 5 el nombre 1.726. Numèricament, el procediment que s'ha de seguir consisteix a dividir per 5 el nombre $1.726 \mathrm{i}$, successivament, els diferents quocients que obtenim en cada divisió fins arribar a un quocient menor que 5, i s'ordenen a continuació els resultats de les diferents divisions. En el numeral que busquem l'últim quocient serà la xifra de les unitats de l'ordre més alt i els residus de les divisions, col·locats en ordre invers al de la seua obtenció, seran les xifres dels ordres descendents següents:

$1.726\lfloor 5$

$$
\begin{gathered}
1345 \frac{5}{69} \\
0 \\
\quad \frac{13}{3} \frac{5}{2}
\end{gathered}
$$

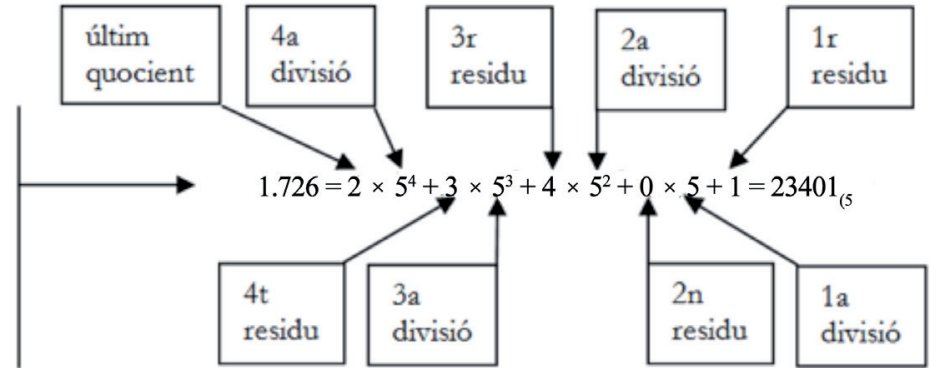

Manipulativament, és com si tinguérem 1.726 peces soltes i el que se'ns demana és fer munts de 5 peces, després de 5 munts, a continuació de 5 munts de 5 munts, i així mentre puguem, ordenant els resultats obtinguts en cada tipus d'agrupament de manera anàloga al cas numèric.

\section{Sistema de numeració en base 2}

És un sistema que s'utilitza molt en l'actualitat en informàtica i en tecnologia. Qualsevol informació s'enregistra mitjançant zeros i uns.

Utilitza les xifres 0 i 1, i es canvia d'ordre d'unitats, afegint una xifra a l'esquerra del numeral, quan s'arriba a un agrupament de dues unitats de qualsevol ordre.

Seguint un procés semblant al descrit per a la base 5, si agafem el 100 i volem passar-lo a base 2, dividim successivament per dos fins a obtenir un quocient menor que aquest nombre i després ordenem les xifres. 
Així:

$$
\begin{aligned}
& 100\lfloor 2
\end{aligned}
$$

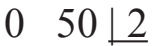

$$
\begin{aligned}
& 0 \quad 25\left\lfloor 2 \quad \mathbf{1 0 0}=\mathbf{1 . 1 0 0 . 1 0 0}{ }_{(2}\right. \\
& 1 \quad 12\lfloor 2 \\
& 0 \quad 6\lfloor 2 \\
& 0 \quad 3\lfloor 2 \\
& \begin{array}{ll}
1 & 1
\end{array}
\end{aligned}
$$

Per esbrinar el valor d'aquesta expressió en base 10, escrivim la descomposició polinòmica corresponent i realitzem els càlculs:

$$
\mathbf{1 . 1 0 0 . 1 0 0}_{(2}=1 \times 2^{6}+1 \times 2^{5}+1 \times 2^{2}=64+32+4=\mathbf{1 0 0} .
$$

\section{Sistema de numeració duodecimal}

En el segle XVIII, el naturalista francès Georges-Louis Leclerc, comte de Buffon (1707-1783), va proposar l'adopció del sistema duodecimal, de base 12, que ja es coneixia de l'antiguitat, per aplicar-lo a les unitats de mesura (Ifrah, 1988).

La raó és fàcil de comprendre: el 10 és un nombre molt gran per a l'escassa quantitat de divisors enters que té. Descartant els obvis 1 i 10, només és divisible per 2 i per 5. En canvi, el 12, un poc més gran, té més divisors. A més de 1'1 i el mateix 12, trobem el 2, el 3, el 4 i el 6 . Aquests divisors eren importants per dues coses: fraccionar la quantitat de mercaderies i el preu de les unitats de mesura dels productes; així, calcular preus i tornar diners era una tasca més senzilla. El costum que hi ha avui de comptar les mercaderies per dotzenes i d'utilitzar en alguns països unitats de mesura que es relacionen entre si de dotze en dotze (un peu: 12 polzades, un xíling: 12 penics...) té l'origen en aquest sistema.

\section{Sistema de numeració sexagesimal}

Aquest sistema és heretat dels sumeris i dels babilonis. La base és el 60, i en l'actualitat es continua utilitzant per mesurar el temps i els angles. La representació dels nombres de l'1 al 59 s'obtenia de manera additiva combinant dos símbols, un per l'1 i un altre pel 10. A partir del 60 el sistema de representació era posicional (Ifrah, 1988). Actualment utilitzem l'sND per representar les quantitats en cada ordre d'unitats sexagesimals, i per aquesta raó cal expressar per separat les unitats dels diferents ordres.

Es pot considerar que s'han mantingut fins als nostres dies per la importància que van tenir els càlculs astronòmics i trigonomètrics dels matemàtics antics. Igual que el sistema de numeració duodecimal, la gran quantitat de divisors que té el 60 (és el menor nombre que es pot dividir al mateix temps per 2, 3, 4, 5 i 6) el feia òptim per a aquest tipus de càlculs. 
En l'actualitat, aquest sistema funciona únicament amb tres ordres d'unitats: segons, minuts i hores o graus, bé s'estiga mesurant temps o bé angles. D'aquesta manera, 60 segons (1r ordre) faran 1 minut ( $2 \mathrm{n}$ ordre), i 60 minuts faran bé una hora, bé un grau ( $3 \mathrm{r}$ ordre). A partir d'aquest ordre, les dues magnituds han evolucionat de manera diferent per construir les noves unitats. Així, en el cas del temps, els dies, les setmanes, els mesos, els anys, etc., ja no s'han format agrupant 60 unitats de l'ordre anterior. En el cas de la mesura d'angles, no hi ha unitat d'ordre superior al grau, tret de la consideració de l'angle complet, que és 360 graus.

S'acusen més diferències si observem les maneres d'expressar els ordres de les unitats. Així, en el cas del temps, escriurem $h$ per indicar les hores, min per indicar els minuts is per indicar els segons; per exemple, 5 h 15 min 43 s. Per al cas dels angles, escriurem ${ }^{\circ}$ per indicar els graus, ' per indicar els minuts $i$ " per indicar els segons; per exemple $5^{\circ} 15^{\prime} 43^{\prime \prime}$.

Quan es vol passar una expressió numèrica de l'SND al sexagesimal, o a l'inrevés, utilitzem criteris de proporcionalitat, és a dir, expressem amb proporcions les equivalències entre els agrupaments decimals i els sexagesimals.

Per exemple, volem saber en el sistema sexagesimal quantes hores, minuts i segons són 3,35 h. En aquest cas, com que l'expressió decimal està donada en hores, la part entera del nombre decimal indica la quantitat d'aquestes unitats, és a dir, 3 hores. Seguidament cal transformar la part decimal en minuts, tenint en compte que si en la part decimal apareixen xifres fins a les centèsimes, en el numerador de la primera fracció de la proporció hi posarem un 100:

$$
\frac{100}{35}=\frac{60}{x} \Rightarrow x=\frac{35 \times 60}{100}=21
$$

Com que no apareixen decimals en la quantitat de minuts obtinguts, no cal buscar segons; aleshores el resultat és $\mathbf{3} \mathbf{h} \mathbf{2 1}$ min.

Novament, si volem saber en el sistema sexagesimal quantes hores, minuts i segons són 3,38 h, procedim de la mateixa manera. Aleshores tenim 3 hores i hem de transformar $0,38 \mathrm{~h}$ en minuts:

$$
\frac{100}{38}=\frac{60}{x} \Rightarrow x=\frac{38 \times 60}{100}=22,8
$$

Com que ara sí que obtenim decimals en els minuts, caldrà separar la part entera, que són 22 minuts, de la part decimal, 0,8 minuts, i aplicant-hi la proporcionalitat corresponent obtenir els segons. Com que en el decimal sols apareixen dècimes, en la fracció inicial col·locarem un 10 al numerador:

$$
\frac{10}{8}=\frac{60}{x} \Rightarrow x=\frac{8 \times 60}{10}=48 \text {. }
$$

En aquest cas el resultat és 3 h 22 min 48 s. 
En l'últim exemple es passarà del sistema de numeració sexagesimal a l'sND. Per realitzar aquests càlculs, cal convertir cada unitat sexagesimal en la triada per l'expressió en l'sND. Si volem saber quants minuts són 5 h 30 min 22 s, caldrà operar de la manera següent:

$$
\begin{aligned}
& 5 \mathrm{~h}=5 \times 60 \mathrm{~min}=300 \mathrm{~min} \\
& 22 \mathrm{~s}=\frac{22}{60} \min =0,37 \mathrm{~min}
\end{aligned}
$$

Per tant, 5 h 30 min $22 \mathrm{~s}$ són en l'sND $(300+30+0,37) \min =330,37 \mathrm{~min}$.

Evidentment, aquests procediments són aplicables de manera anàloga al cas de la mesura d'angles.

En l'ús quotidià de les expressions de la mesura del temps, cal evitar interferències incorrectes entre l'sND i el sistema sexagesimal. Així:

- Cinc hores i mitja no són 5,30 h; són 5,5 h o bé 5 h 30 min.

- Tres quarts d'hora no són 0,45 h; són 0,75 h o bé 45 min.

- Un quart d'hora no és $0,15 \mathrm{~h}$; és $0,25 \mathrm{~h}$ o bé $15 \mathrm{~min}$.

\section{Els Nombres Naturals a l'aula de Primària}

\subsection{Consideracions prèvies}

Quan els alumnes comencen l'etapa d'escolarització obligatòria, l'Educació Primària, no és la primera vegada que tenen accés als nombres, fet que cal tenir molt present. La quotidianitat amb què el nombre es presenta en el nostre medi, siga parlat o siga escrit, en qualsevol de les diferents manifestacions de comunicació que establim, fa que estiga com a habitual en el seu conscient, des d'edats molt primerenques, la presència d'uns mots i d'uns signes, grafies o guarismes que representen o expliquen coses que passen al seu voltant.

Vol dir açò que hi ha una idea formada a dins seu sobre què signifiquen aquests nombres? Segurament encara no, fins i tot havent cursat l'Educació Infantil, i aquesta és la tasca que cal desenvolupar a l'Educació Primària: que el nombre siga entès com la invenció que les persones han fet per tal de representar, simbolitzar, anomenar les quantitats i també ordenar-les. Això en un primer moment. És evident que hi ha més usos del nombre natural, però aquestes dues funcions són un dels objectius principals del tema. Estem parlant de les funcions cardinal i ordinal, que de ben segur estan incorporades de manera intuitiva al pensament dels xiquets 
abans d'entrar a l'escola: «tinc cinc joguets», «tinc més joguets que tu». Aquestes dues idees, podem considerar-les com a punt de partida a l'hora de treballar en Educació Primària.

Si ens preguntem «quins continguts es treballen dels 6 als 11 anys en aquest tema que correspon al bloc nombres i operacions», en la resposta hem d'incloure, a més de completar la conceptualització numèrica que poden portar de l'Educació Infantil, la introducció i el desenvolupament de l'SND. Per avançar en aquest contingut, construirem a partir d'agrupaments de 10 en 10, les idees de desena, centena, unitat de miler, etc., introduint les noves simbolitzacions corresponents per resoldre un problema, que no és sols el de comptar, és també el d'aclarir-nos en representar els nombres quan són molts els elements considerats. Deixarem les operacions per al tema següent d'aquesta publicació.

I tot això sense oblidar que la numeració, com a part de les Matemàtiques, té el seu punt de partida i d'arribada en la realitat i que el nostre treball matemàtic a l'aula serà significatiu, en la mesura que ho contextualitzem socioculturalment i l'integrem en un treball globalitzat que no deixe com a compartiment estanc qualsevol tipus de saber.

Aquestes consideracions es complementen necessàriament amb la utilització de materials didàctics específics que recolzen la construcció de l'SND.

\subsection{Materials utilitzats per treballar els sistemes de numeració}

De la gran quantitat de materials que ens podem trobar en Educació Primària per treballar l'SND, analitzarem a continuació els tres següents: blocs multibase, àbacs i reglets cuisenaire; encara que utilitzarem preferentment els blocs multibase i els àbacs per ser els que considerem que ajuden millor en la construcció dels coneixements relacionats amb el sistema de numeració decimal.

\subsubsection{Blocs multibase}

Els blocs multibase de Dienes són un recurs matemàtic dissenyat perquè els xiquets i les xiquetes puguen comprendre els sistemes de numeració sobre una base manipulativa concreta, a partir d'unes peces la grandària de les quals ens informa del seu valor en el nombre.

Aquest material consta d'una sèrie de peces, tradicionalment de fusta, que representen les unitats de primer, segon, tercer i quart ordre en diferents sistemes de numeració posicional (unitats, desenes, centenes i unitats de miler, en el cas del sistema de numeració decimal). Es presenten en forma de: 
- Cubs d'1 cm d'aresta, que representen les unitats simples o de primer ordre.

- Reglets. Prismes quadrangulars d' $1 \mathrm{~cm}^{2}$ de secció i $b \mathrm{~cm}$ de llargària (on $b$ és la base del sistema de numeració). Estan compostos de tants cubs units com marque la base del sistema de numeració; si s'utilitza base deu, el reglet constarà de deu cubs units; cada unitat està perfectament assenyalada per una ranura. Representen les unitats de segon ordre. En l'sND, correspondrien a les desenes.

- Plaques. Prismes quadrangulars de $b^{2} \mathrm{~cm}^{2}$ de base i $1 \mathrm{~cm}$ d'alçada (on $b$ és la base del sistema de numeració). Estan compostes de tants reglets units com marque la base del sistema de numeració. Representen les unitats de tercer ordre. En l'SND correspondria a les centenes.

- Blocs. Cubs de $b^{3} \mathrm{~cm}^{3}$ (on $b$ és la base del sistema de numeració). Estan compostos de tantes plaques unides com marque la base del sistema de numeració. Representen les unitats de quart ordre. En l'sND, el bloc tindria $10 \times 10 \times 10$ cubs, és a dir, 1.000 cubs, i, per tant, representaria la unitat de miler.

En les imatges de la figura 15 es mostren en fusta les peces per als materials de base 10 i de base 2 .
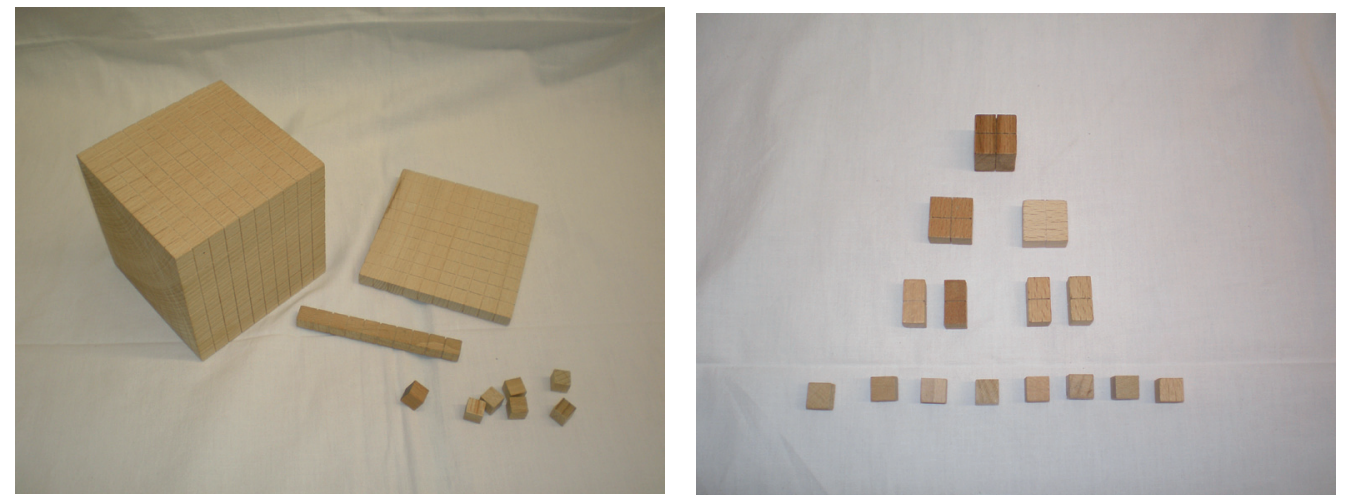

Figura 15. Blocs multibase de base 10 (esquerra) i base 2 (dreta) (fabricats per Tauvi)

Per esbrinar la representació d'un determinat nombre amb aquest material s'ha de començar agrupant els cubs corresponents a aquest nombre i substituint cada grup de $b$ peces d'un tipus per una peça del tipus següent (cada $b$ unitats d'un ordre per una unitat de l'ordre següent).

A la figura 16, trobem un exemple concret de la representació final d'un nombre amb blocs multibase (en aquest cas en plàstic), una vegada s'ha fet la manipulació i els canvis de peces necessaris que afavoreixen la representació del numeral. 


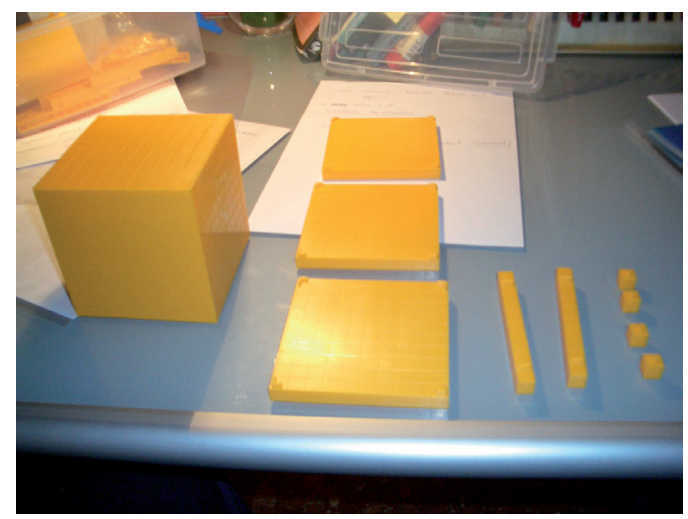

Figura 16. Representació del nombre 1.324 amb blocs multibase de base 10 (fabricats per Miniland)

Aquest material permet veure clarament i comprendre el valor de cadascuna de les unitats dels diferents ordres que componen un nombre. També els podem fer servir per:

1. Fer agrupaments amb els cubs en bases diferents.

2. Treballar els conceptes d'unitats d'ordre superior amb un suport concret.

3. Arribar a comprendre el valor posicional de les xifres; així, al cub, se li suposa un valor diferent del d'un reglet.

4. Fer les operacions d'addició i subtracció.

5. Treballar els conceptes de doble i meitat.

6. Iniciar de manera manipulativa les operacions de multiplicació i divisió.

7. Ajudar a la resolució de problemes quotidians amb les operacions amb nombres naturals.

8. Treballar les fraccions i els nombres decimals.

9. Refermar els conceptes introduïts amb altres recursos.

10. Utilitzar els blocs com a unitats de mesura de longitud, superfície i volum.

Aquest material pot ser substituït per altres de fabricació pròpia que permeten la mateixa conceptualització mitjançant una manipulació semblant. Cal tenir en compte que el que es pretén és tenir un suport manipulable en el qual es puguen distingir els diferents ordres dels sistema de numeració a partir de la seua mesura o aspecte extern. Així, per exemple, els cigrons poden recrear les unitats i amb bossetes es poden agrupar els ordres superiors (una bosseta de 10 cigrons serà una desena, una caixa amb 10 bossetes de les anteriors serà una centena...). Els macarrons (o palets de plàstic del cafè) representaran les unitats i amb fil es poden enfilar i agrupar en funció dels ordres (10 macarrons enfilats formen una desena, una bossa amb 10 enfilats dels anteriors forma una centena...). 


\subsection{2. Àbacs}

Un àbac és una eina que serveix per representar nombres de manera posicional i per al càlcul manual d'operacions aritmètiques. Generalment, consisteix en un suport horitzontal amb varetes verticals per on es fan córrer boles o anelles o fitxes perforades..., en endavant optarem per anomenar-les boles. S'hi poden representar nombres en la base que es vulga, i cada vareta de boles representa de dreta a esquerra les unitats simples o de primer ordre, les unitats de segon ordre i així successivament.

Per representar un determinat nombre amb aquest material s'han de colllocar les boles corresponents al nombre en la primera vareta de la dreta, substituint cada grup de $b$ boles d'una vareta per una bola en la vareta immediata a l'esquerra (cada $b$ unitats d'un ordre per una unitat de l'ordre següent).

N'hi ha de diferents tipus:

1. Àbacs tancats, les varetes dels quals tenen forma de U invertida. Poden tenir 10 o 20 boles per guia (figura 17).
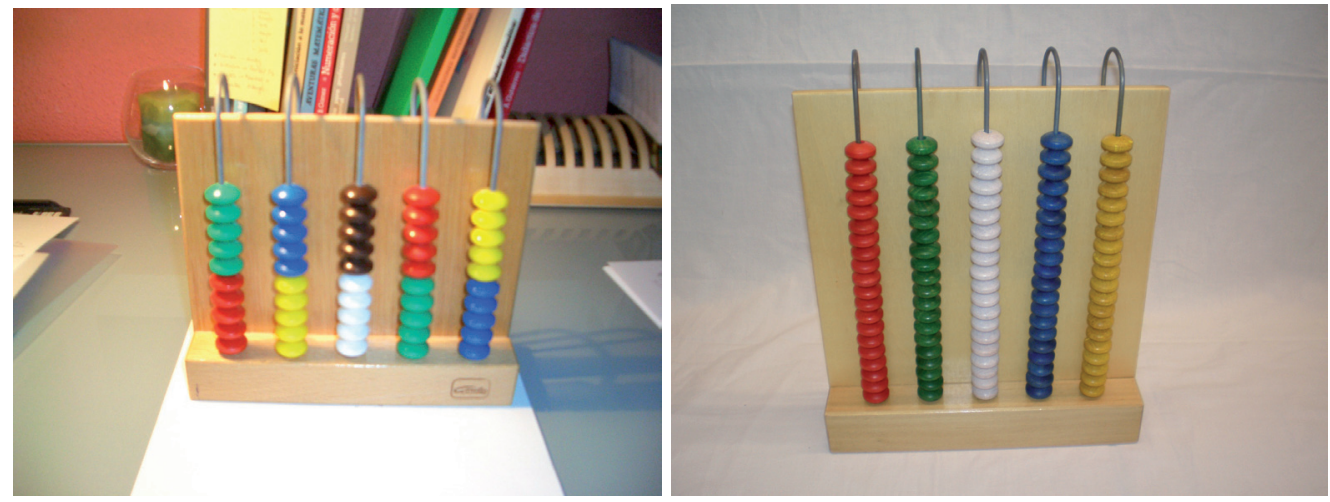

Figura 17. Àbacs verticals tancats de 10 boles (esquerra) i 20 boles (dreta) (fabricats per Goula)

Els de 10 boles no permeten realitzar operacions portant-ne a l'sND, sols s'usen per representar nombres i per a operacions sense portar-ne.

Els de 20 boles sí que ho permeten, però hem de tenir cura en la identificació errònia que els xiquets poden fer del color de les boles dels diferents ordres d'unitats. Així, és convenient utilitzar àbacs que no tinguen els mateixos colors de boles per als mateixos ordres d'unitats o àbacs que utilitzen boles d'un mateix color per tots els ordres d'unitats o àbacs que no tinguen en cada vareta totes les boles del mateix color.

2. Àbacs oberts, les varetes dels quals són completament verticals i en les quals es poden posar boles o anelles combinant els colors de manera que s'eviten els problemes esmentats pels àbacs tancats (figura 18). 


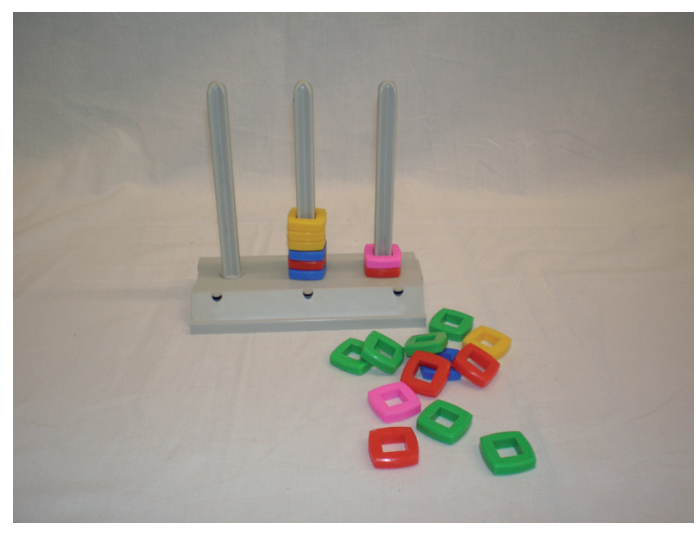

Figura 18. Àbac vertical obert de 3 varetes en el qual s'ha representat el nombre 62 (fabricat per Nathan)

Com es pot observar en les figures $17 \mathrm{i} 18$, hi ha àbacs de diferent nombre de varetes. Podem aconseguir expressar quantitats grans alineant més d'un àbac.

Molts dels objectius que s'han descrit per als blocs multibase es poden treballar igualment amb els àbacs que exigeixen un nivell d'abstracció numèrica més elevat, atès que la grandària de les boles no ens informa del seu valor, sinó que és necessari tenir clara la seua posició per a conèixer-lo.

De manera semblant al darrer apartat dels blocs multibase, els àbacs comercialitzats poden ser substituïts per altres fabricats amb materials propis. Per exemple, en una base de suro s'incrusten verticalment llapisseres i s'utilitzen anelles (de fusta, de plàstic, de cartró...) per representar les unitats dels diferents ordres. També es poden utilitzar àbacs plans mitjançant el dibuix de columnes que s'emplenen amb cigrons, botons o altres objectes que indiquen la quantitat de les diferents unitats. A la part de dalt o baix de cada columna s'escriurà la inicial corresponent als noms de les unitats de cada ordre.

\subsubsection{Els reglets Cuisenaire}

Els reglets Cuisenaire són un material matemàtic els objectius del qual són que els xiquets i les xiquetes aprenguen la composició i la descomposició dels nombres i iniciar-los en les activitats de càlcul, tot això sobre una base manipulativa. El material consta d'un conjunt de reglets de fusta o plàstic (prismes quadrangulars) d' $1 \mathrm{~cm}^{2}$ de secció, de deu longituds que van d' 1 a $10 \mathrm{~cm}$ i de 10 colors diferents associats cadascun a una determinada longitud. Cada reglet representa un nombre determinat:

- El reglet blanc, amb $1 \mathrm{~cm}$ de longitud, representa el nombre 1.

- El reglet roig, amb $2 \mathrm{~cm}$, representa el nombre 2.

- El reglet verd clar, amb $3 \mathrm{~cm}$, representa el nombre 3.

- El reglet rosa, amb $4 \mathrm{~cm}$, representa el nombre 4.

- El reglet groc, amb $5 \mathrm{~cm}$, representa el nombre 5. 
- $\quad$ El reglet verd fosc, amb $6 \mathrm{~cm}$, representa el nombre 6 .

- El reglet negre, amb $7 \mathrm{~cm}$, representa el nombre 7.

- El reglet marró, amb $8 \mathrm{~cm}$, representa el nombre 8.

- El reglet blau, amb $9 \mathrm{~cm}$, representa el nombre 9.

- El reglet taronja, amb $10 \mathrm{~cm}$ representa el nombre 10.

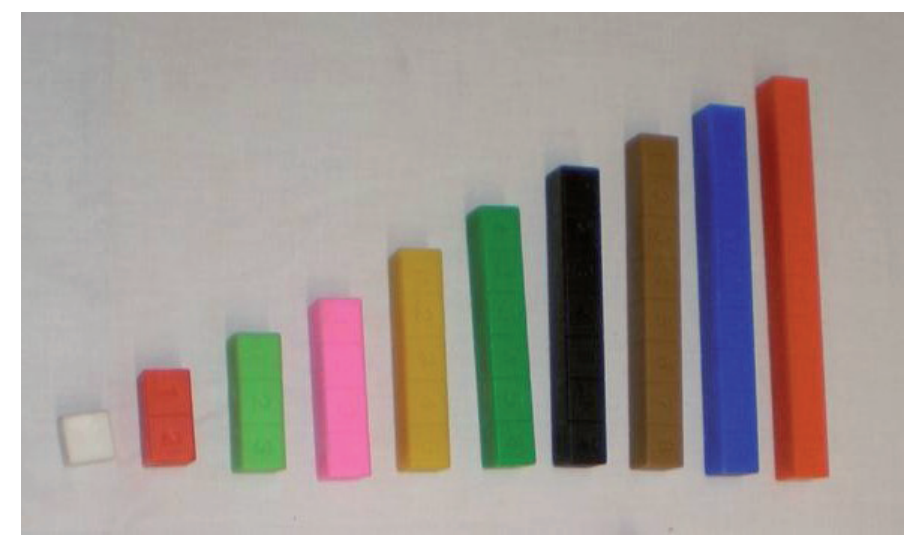

Figura 19. Reglets Cuisenaire ordenats de 1'1 al 10 (fabricats per Lado)

Els objectius que volem aconseguir amb aquest material són:

1. Associar la longitud amb el color corresponent.

2. Completar la sèrie numèrica de 1'1 al 10 de manera ascendent i descendent.

3. Comprovar la relació d'inclusió de la sèrie numèrica.

4. Treballar manipulativament les relacions «major que», «menor que» dels nombres basant-se en la comparació de longituds.

5. Realitzar composicions i descomposicions de nombres.

6. Construir la desena i treballar els nombres de dues xifres.

7. Iniciar les operacions d'addició i subtracció de manera manipulativa.

8. Comprovar empíricament les propietats commutativa i associativa de l'addició.

9. Iniciar la multiplicació.

10. Comprovar empíricament les propietats de la multiplicació.

11. Iniciar la divisió.

12. Iniciar-los en els conceptes doble i meitat.

13. Introduir fraccions i decimals.

14. Treballar la divisibilitat.

\subsection{Capacitats que cal desenvolupar a l'aula de Primària}

Com establir els primers passos d'una manera seqüencial i adequada a $1 \mathrm{r}$ cicle d'Educació Primària respecte dels Nombres Naturals també serà l'objectiu del tema, que contribuirà a desenvolupar en l'alumnat les capacitats següents:

1. Classificar conjunts segons el seu cardinal.

2. Ordenar conjunts segons el seu cardinal i ordenar els cardinals d'aquests conjunts. Comptar progressivament i regressivament. 
3. Descobrir les regles dels sistemes de numeració posicionals a partir de l'agrupament d'objectes. Verbalitzar i representar gràficament els agrupaments realitzats.

4. Introduir l'SND. Construir les unitats dels diferents ordres (desenes, centenes...): xifres i nombres. Llegir i escriure nombres naturals.

5. Descompondre els nombres naturals atenent al valor posicional de les xifres, i arribar a expressar-los en forma polinòmica.

6. Ordenar nombres naturals. Introduir el vocabulari i la notació corresponents. Comptar progressivament i regressivament.

7. Reflexionar sobre els diferents usos dels nombres naturals en situacions quotidianes.

8. Llegir i escriure quantitats en el sistema de numeració romà.

9. Introduir el sistema de numeració sexagesimal.

\subsection{Desenvolupament de les capacitats}

En aquest apartat es recorren per ordre creixent de dificultat els procediments per a la construcció dels conceptes que es treballen al tema, des del primer contacte que els xiquets hi tenen a l'aula, fins al grau d'adquisició que se'n pot aconseguir en finalitzar aquesta etapa.

En general, treballarem a partir de situacions reals que es plantegen i es desenvolupen a l'aula $\mathrm{i}$ en l'entorn, $\mathrm{i}$ haurem d'aprofitar les experiències anteriors dels xiquets i xiquetes per agafar-les com a punt de partida per a la construcció dels conceptes matemàtics corresponents. En aquest procés haurem de tenir en compte la necessitat de partir d'activitats manipulatives/experimentals que, acompanyades de la necessària verbalització, es dirigiran cap a la representació matemàtica dels conceptes i també cap a l'abstracció que puga aconseguir aquest alumnat.

Els materials didàctics específics són una ajuda que sempre cal tenir a l'aula d'Educació Primària com a complement de les situacions abans esmentades, perquè el seu ús possibilita la creació de referents gràfics i imatges mentals als quals recórrer quan s'intenta fer qualsevol pas cap a l'abstracció.

Cal invertir temps per conèixer les possibilitats que un material ofereix, pensar activitats per desenvolupar les potencialitats dels alumnes d'Educació Primària i, evidentment, treballar les capacitats que s'estudien a continuació.

S'aconseguirà dotar una aula d'Educació Primària amb el material didàctic necessari, bé comprant-lo en tendes especialitzades, bé construint-lo el mateix docent amb ajuda de l'alumnat i/o dels familiars. 


\section{Classificar conjunts segons el seu cardinal}

El que es pretén ara és comprovar si tenen interioritzat el concepte de nombre associat a la idea de quantitat i si són capaços de considerar aquesta com una propietat característica dels conjunts que els permet agrupar-los per tal de formar classes de conjunts equivalents.

Al principi del 1r curs de Primària es continuarà el treball iniciat en Educació Infantil, perquè es tracta d'aprofundir en el coneixement del concepte de nombre, per aconseguir que l'alumnat l'integre de manera natural en el seu pensament atès que el nombre és un concepte que sempre està present en la realitat.

Podem desenvolupar aquest treball a partir d'un material preparat, buscat o construit per nosaltres mateixos en el qual, junt amb qualitats com ara colors, formes, etc., aparega també la quantitat com una més de les característiques de les peces que componen el material. Per exemple, preparem 24 bosses i 24 gots de plàstic transparent, amb 3, 4 o 5 caramels del mateix tipus (amb pal o sense pal) i del mateix sabor (maduixa, taronja, llima o meló) en cada recipient. Caldrà que ho classifiquen de totes les maneres possibles que se'ls puga ocórrer.

En un primer moment el criteri triat serà el sabor, el tipus de caramel o el de recipient, per tal de fer les classes d'equivalència. Posteriorment, insistint que continuen classificant de maneres diferents de les que ja ho han fet, ha d'aparèixer espontàniament la classificació pels cardinals, és a dir, l'agrupació de tots els envasos que hi tinguen tres caramels, per un costat, tots els que n'hi tinguen quatre, per altre, $\mathrm{i}$ tots els que n'hi tinguen cinc per altre.

En aquest moment és quan ja han considerat el cardinal del conjunt com una propietat que pot caracteritzar conjunts i, per tant, pot servir com a criteri per classificar els conjunts. S'ha produït de manera natural l'associació quantitat i nombre, per tant s'ha identificat el nombre amb la quantitat que li correspon.

De manera anàloga a allò que ocorre en les classificacions anteriors (amb pal, els de llima, les bosses...), podem posar nom a cadascun dels conjunts del darrer agrupament. Així, el nom que correspon a la classe d'equivalència formada per tots els envasos de tres caramels podria ser els de 3. Els de 4 seria el nom de la classe formada pels envasos amb quatre caramels i els de 5 seria el de la classe formada pels de cinc caramels. Cal adonar-se que estem fent ús de la definició formal de nombre natural segons Cantor (vegeu la introducció d'aquest tema) i que les classes obtingudes en la darrera classificació s'han construït en aplicar la relació binària d'equivalència «tenir el mateix cardinal». Serà, doncs, el nombre natural allò que caracteritza tots els conjunts d'una mateixa classe.

També és convenient que miren al voltant i troben situacions en les quals es classifiquen conjunts pel seu cardinal: envasos amb ous, caixes de llapis de colors, de gomes d'esborrar, paquets de fulls, etc. 
Més endavant treballarem aquesta capacitat utilitzant materials gràfics en els quals aparega el cardinal com una de les característiques de les peces d'aquest. Per exemple, podem fabricar un material compost per fitxes de cartolina amb dibuixos de flors, arbres i bolets, de tres colors diferents i amb dos, tres o quatre dibuixos iguals en cada fitxa.

Poden classificar-les per colors i per figures de manera bastant fàcil. El nostre interès serà que ho facen també pel nombre de dibuixos de cada fitxa, per arribar a les mateixes finalitats que al cas de les activitats manipulatives.

És imprescindible que l'alumnat verbalitze tot el treball que faça amb objectes reals o gràfics i que expresse correctament les relacions que s'estableixen entre les diferents peces dels materials $i$ les igualtats numèriques que es tenen en compte per establir les classes d'equivalència.

\section{Ordenar conjunts segons el cardinal i ordenar els cardinals d'aquests conjunts. Comptar progressivament i regressivament}

Com a complement de la capacitat anterior es pretén ara comprovar si l'alumnat de $1 \mathrm{r}$ de Primària és capaç d'ordenar els nombres que s'han estudiat en Educació Infantil.

Començarem comparant les quantitats d'elements de tres conjunts que poden correspondre o no a nombres consecutius i, després de verbalitzar les seues desigualtats, s'arribarà a l'expressió de l'ordre entre els nombres implicats. Per exemple, si a la cistella on els xiquets i les xiquetes deixen els esmorzars tenim dos entrepans de paté, quatre de tonyina i sis de pernil dolç, entre d'altres, ordenaran els conjunts corresponents $\mathrm{i}$ verbalitzaran: "hi ha menys entrepans de paté que de tonyina $\mathrm{i}$ menys de tonyina que de pernil dolç», per poder dir a continuació que dos és menor que quatre i quatre és menor que sis. Evidentment, també es podria realitzar la comparació inversa i ordenar així els nombres de major a menor.

Aquestes situacions, que treballarem primerament amb objectes reals i després amb representacions gràfiques, aniran complicant-se fins que puguen arribar a ordenar nou conjunts i, amb ells, els nou nombres associats.

És important que completem aquestes activitats amb d'altres en les quals siga necessari comptar ordenadament diferents quantitats d'objectes per ajudar-los a fixar l'ordenació dels nombres de manera natural en el seu pensament. Podem ajudar-nos de jocs o cançons (els elefants en la tela de l'aranya, les pometes, les ampolles...) en les quals el comptatge es realitze tant progressivament com regressiva, acompanyant-lo de la representació real d'allò que estan cantant, perquè no es tracte sols de recitar els nombres sense més, sinó d'associar-los a la quantitat d'objectes que els correspon. 
Per començar aquest treball i mostrar la utilitat de la base per fer comptatges de nombres elevats, podem provocar una situació de classe en la qual l'alumnat està organitzat per grups i tots els grups disposen de la mateixa quantitat elevada de caramels, que han de ficar en bosses de plàstic per a una festa de benvinguda al collegi. Se'ls demana que preparen les bosses ficant-hi munts (o pilots o grapats) del mateix nombre de caramels, que serà superior a un per evitar la utilització d'una bossa per a cada caramel, i que diguen després en assemblea quants caramels té cada grup expressant-lo amb ajuda de la quantitat de munts que han fet (de bosses que han utilitzat) i de la quantitat de caramels que han ficat en cada bossa (que serà la base del sistema que estan utilitzant per comptar).

Si el nombre de caramels que proporcionem a cada grup és primer (43, per exemple) no podran fer tots els munts de la mateixa quantitat i necessàriament hauran de explicar i expressar el que ocorre. D'aquesta manera arribarem a expressions del tipus: «tenim 7 munts de 6 caramels i ens n'ha sobrat 1 »o «tenim 8 munts de 5 caramels i ens n'han sobrat $3 »$, que poden abreujar-se escrivint respectivament: $7 \mathrm{~m} 6 \mathrm{~s} 1$ o $8 \mathrm{~m} 5 \mathrm{~s} 3$.

Si el nombre no és primer (40, per exemple) podem trobar algun grup d'alumnat al qual no li quede cap caramel solt: «tenim 6 munts de 6 caramels i en sobren 4» o «tenim 8 munts de 5 caramels i no en sobre cap», que poden expressar-se: $6 \mathrm{~m} 6$ $\mathrm{s} 4$ o $8 \mathrm{~m} 5 \mathrm{~s} 0$.

En qualsevol dels casos, com que saben que cada grup tenia la mateixa quantitat de caramels, es generarà un conflicte en comprovar que cadascun n'ha obtingut una expressió diferent. També els podem plantejar dubtes si no els avisem de què tots els grups tenen la mateixa quantitat els demanem que ens diguen si un grup té més caramels que un altre, ja que no saben si fixar-se en el nombre de munts o en el d'elements de cada munt per esbrinar-ho. Podem trobar-ne alguns que pensen « $7 \mathrm{~m} 6 \mathrm{~s} 1$ és major que $5 \mathrm{~m} 8 \mathrm{~s} 3$ perquè hi ha més munts» o d'altres que pensen « $5 \mathrm{~m} 8 \mathrm{~s} 3$ és major que $7 \mathrm{~m} 6 \mathrm{~s} 1$ perquè els munts són més grans».

La reflexió sobre aquests conflictes els ha de portar a la necessitat que tots els grups facen els munts de la mateixa quantitat de caramels per poder entendre's. Com que fa falta que puguem entendre'ns no sols amb els alumnes de la classe sinó amb totes les altres persones, els preguntarem com compten els altres, per arribar a la conclusió que, de manera universal, els agrupaments es fan de 10 en 10. Aquesta conclusió obre la porta a la capacitat següent $i$ al treball específic amb l'sND.

\section{Introduir l'SND. Construir les unitats dels diferents ordres (desena, centena...): xifres i nombres. Llegir i escriure nombres naturals}

D'acord amb el treball realitzat en la capacitat anterior i el que desenvoluparem amb aquesta, el procediment per construir l'SND a les aules de Primària recorrerà les fases següents: descobrir la conveniència de l'elecció d'una base pels comptat- 
ges; reflexionar sobre la necessitat de la unicitat de la base; introduir la base $10 \mathrm{i}$, a partir d'aquesta, les unitats dels diferents ordres, per arribar a la generalització del funcionament de l'SND.

Una vegada hem arribat al 10 com la quantitat a partir de la qual agrupem els objectes que estem comptant, és a dir, com la base del sistema de numeració que utilitzarem, cal reflexionar al voltant d'aquest nombre que no és només el que segueix al 9, sinó el primer que necessita dos dígits per escriure'l.

Fins ara, sempre que s'afegia una unitat a un nombre conegut, apareixia un nou nombre que es representava amb un sol dígit. Va passar així amb el $2=1+1$, el $3=2+1, \ldots$, el $9=8+1$. No és el cas del 10. És evident que l'alumnat ja el pot conèixer per àmbits exteriors al treball realitzat a classe, o també a dins, quan el 10 ha aparegut per qualsevol motiu circumstancial. Però caldrà reflexionar que no hi ha un nou dígit, diferent als anteriors, per expressar aquest nombre sinó que la seua representació està formada per dos dígits ja coneguts, l'1 i el 0 , que ens indiquen el nombre de munts que hem fet, 1'1, i el de unitats que han sobrat, el 0, ordenats de la mateixa manera que hem ordenat les expressions alfanumèriques dels nombres que han obtingut quan han agrupat caramels, és a dir, a l'esquerra situem el dígit que indica els munts que hem fet $\mathrm{i}$ a la dreta el que indica les unitats que han quedat soltes. Així, $9+1=10$, que també es pot expressar com $1[10] 0$, si es fa necessari per facilitar la comprensió de l'estructura d'aquest numeral (on el 10 a dins dels claudàtors indica el nombre d'elements que componen cada agrupament).

En aquests moments, quan arribem a nombres que necessiten més d'un dígit per representar-los, hem d'introduir el concepte de xifra per a referir-nos a cadascun dels dígits individuals que coneixem d'Educació Infantil i que utilitzarem a partir d'ara per representar els nombres més grans que 9.

Per recolzar l'aprenentatge dels nombres podem utilitzar materials estructurats, com els blocs multibase de Dienes (BM) i els àbacs, ja coneguts. És el moment de treballar el funcionament d'aquests materials quan representem l'SND (vegeu 4.2). Així en els BM, quan afegim un cub a nou més, obtenim deu cubs que se substituiran per un reglet. Aleshores el 10 simbolitzarà el que hi ha al material: 1 reglet $\mathrm{i} 0$ cubs solts (figura 20).
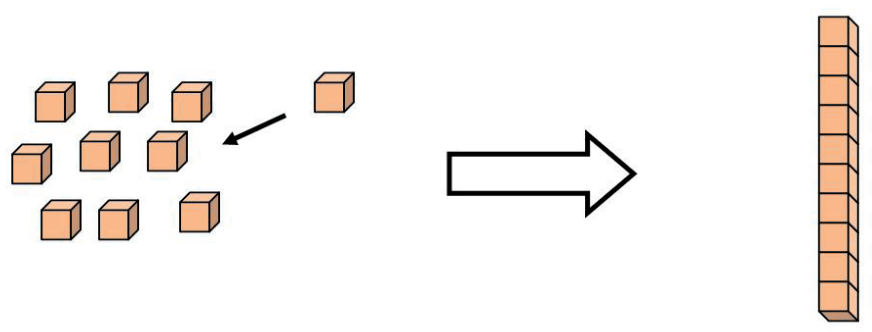

Figura 20. Construcció del 10 amb blocs multibase 
Amb els àbacs, quan afegim una bola a les nou de la primera vareta per la dreta, obtenim deu boles que se substituiran per una en la següent vareta a l'esquerra. Hi queden, cap bola a la vareta de la dreta i una a la de l'esquerra. Per tant, el pas a l'expressió simbòlica està clar: el 10 representa el material perquè hi ha 1 bola a l'esquerra $i$ cap a la dreta en les dues primeres varetes comptabilitzades de dreta a esquerra (figura 21).

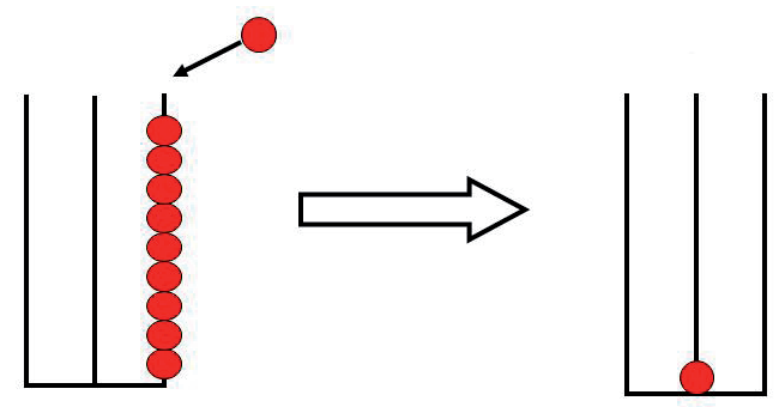

Figura 21. Construcció del $10 \mathrm{amb}$ àbacs

Amb aquest treball hem construït una unitat d'un nou ordre, en aquest cas el segon, i per tant, cal treballar els quatre aspectes següents:

- Nom: desena

- Valor: 10 unitats

- Escriptura: 10

- Lectura: 10

A partir que els xiquets i xiquetes coneguen la paraula desena, podem representar també el deu com 1D 0U, si resulta aclaridor per a l'alumnat.

Al llarg de 1r de Primària cal arribar fins a la construcció de l'expressió del 99 associant el treball amb situacions en les quals apareguen els diferents nombres de dues xifres. S'aniran construint amb les ajudes necessàries i es veurà com s'escriuen, com es lligen... Per exemple, a partir de la necessitat de saber quant d'alumnat hi ha entre les dues classes de 1r de Primària per fer una excursió i comprar les entrades del museu que es visitarà, es planteja esbrinar l'expressió correcta del nombre corresponent. Davant la dificultat d'ajuntar-los en aquest precís moment, la mestra els ofereix una quantitat de cubs dels BM equipotent a la quantitat d'alumnes que volen comptabilitzar (47 en aquest cas). Els demana que els agrupen intercanviant cubs per reglets quan siga necessari, fins a arribar a l'expressió buscada. En les figures 22 a 26 es mostren els passos successius per arribar a l'expressió final.

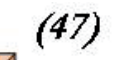

Figura 22. Es disposen els 47 cubs de manera individual 


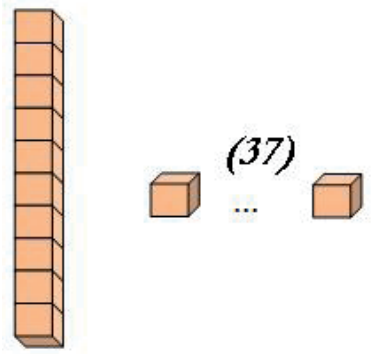

Figura 23. Resultat de la primera agrupació: 1 reglet i 37 cubs solts

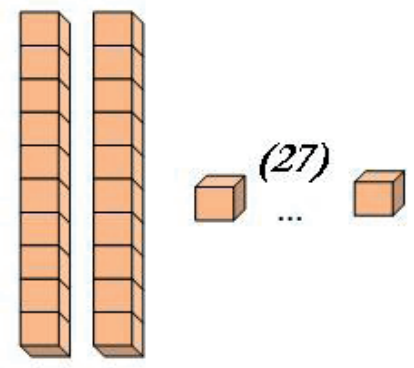

Figura 24. Resultat de la segona agrupació: 2 reglets i 27 cubs solts

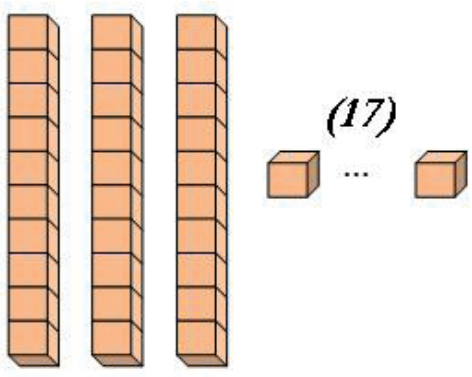

Figura 25. Resultat de la tercera agrupació: 3 reglets i 17 cubs solts
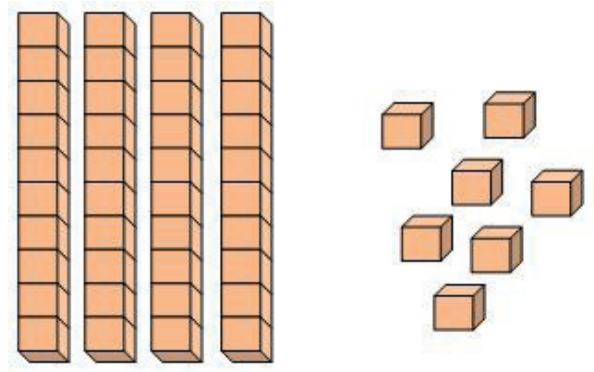

Figura 26. Resultat de la quarta agrupació: 4 reglets i 7 cubs solts

En cas que el material que s'utilitze a l'aula siguen els àbacs, es partirà de 47 boles i un àbac obert. Cada vegada que situen 10 boles a la vareta de les unitats, les substitueixen per 1 a la de les desenes, fins a arribar a tenir la representació final. En les figures 27 a 31 es mostren els passos successius per arribar a l'expressió final. 


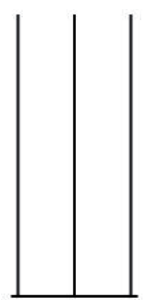

(47)

Figura 27. Es disposen les 47 boles de manera individual al costat d'un àbac

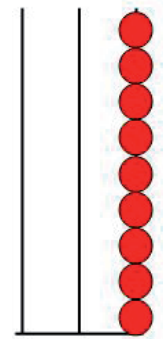

$\overbrace{}^{(37)}$
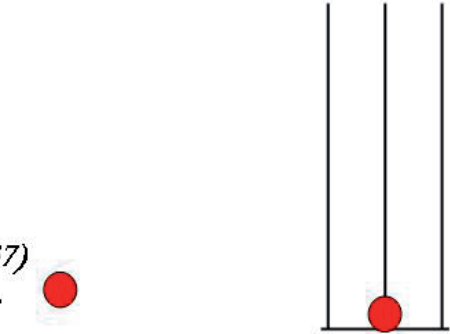

(37)

Figura 28. Procés i resultat de la primera agrupació: 1 bola a la vareta de les desenes i 37 boles soltes
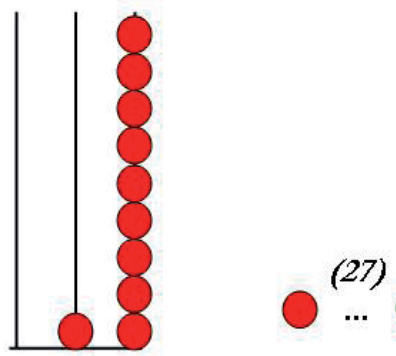

\section{(27)}

Figura 29. Procés i resultat de la segona agrupació: 2 boles a la vareta de les desenes

Figura 29. Proces i resultat de la segona agrupacio:
\[ \mathrm{i} 27 \text { boles soltes } \]
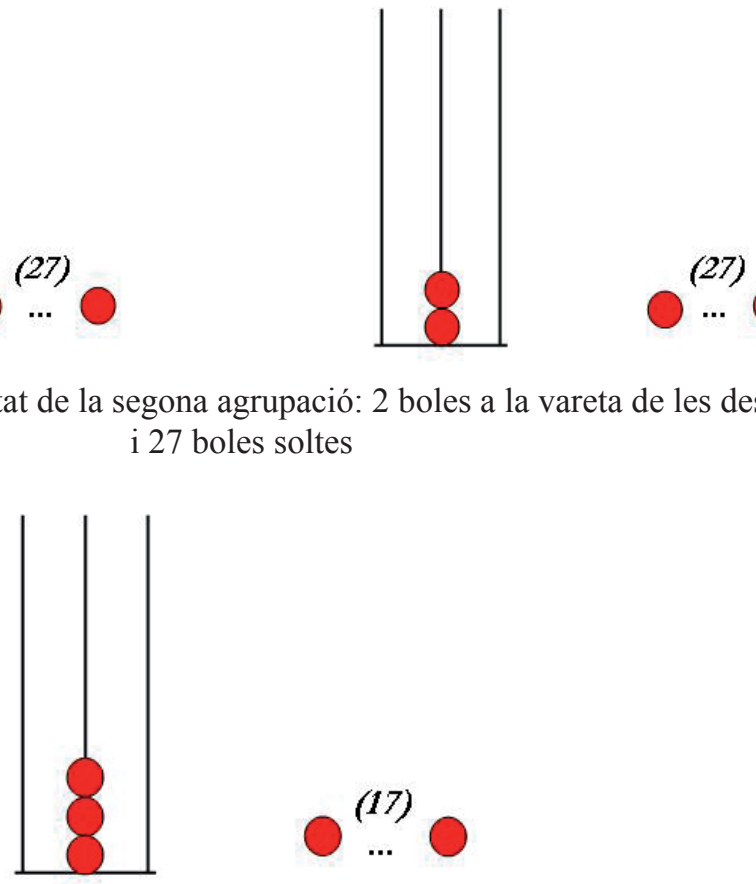

Figura 30. Resultat de la tercera agrupació: 3 boles a la vareta de les desenes i 17 boles soltes

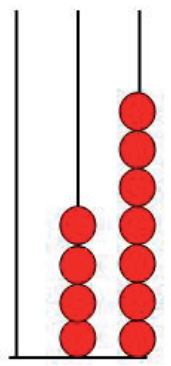

Figura 31. Resultat de la quarta agrupació: 4 boles a la vareta de les desenes i 7 boles a la de les unitats 
En tot aquest procés de construcció dels nombres es pot usar, en els primers moments o quan hi apareguen dificultats, les escriptures intermèdies esmentades anteriorment que es puguen identificar amb els materials més intuïtivament que la representació estàndard i que reforce el procediment pel qual es van agrupant i creant les expressions numèriques en l'sND. En l'exemple anterior, el 47, es pot representar per 4[10] 7 (usant la lògica de 4 barres i 7 cubs, o bé de 4 boles a la segona vareta i 7 a la primera, si és que s'usaren àbacs) o bé per 4D 7U (usant els noms de les unitats del diferents ordres de l'SND).

Quan es produeix el canvi a la desena següent, del 19 al 20, del 29 al 30..., hi poden aparèixer dificultats. És necessari que quede molt clar que, per exemple, en afegir una unitat al 19 s'obté un nou grup de 10 unitats, que ens permet formar una nova desena i, per tant, obtenir el 20 (figures 32 i 33).

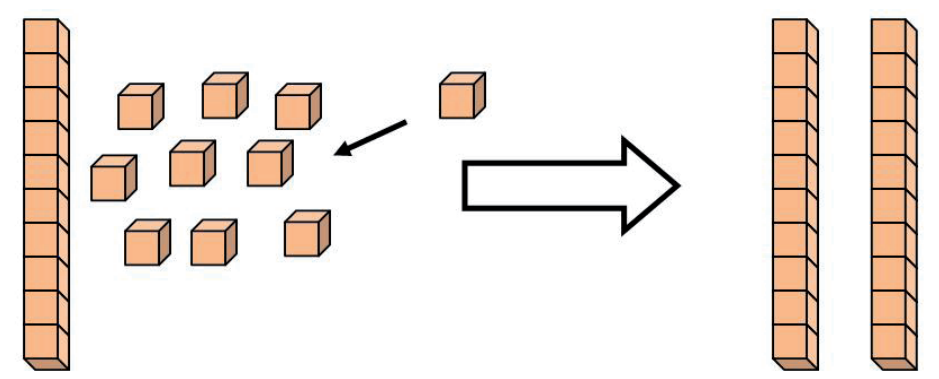

Figura 32. Representació amb BM de la construcció de la segona desena

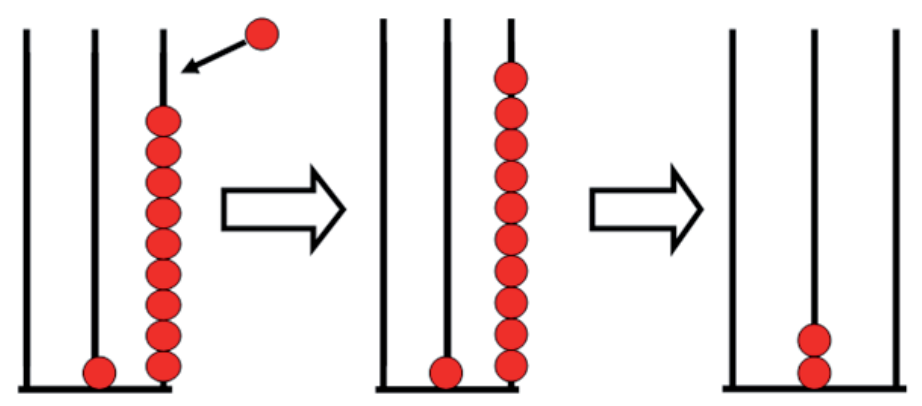

Figura 33. Representació amb àbacs de la construcció de la segona desena

En qualsevol dels dos casos, cal fer un esforç per traslladar a l'escriptura numèrica el que s'està treballant amb els materials i s'ha verbalitzat amb l'alumnat, s'obté d'aquesta manera la representació del nou nombre:

$$
\begin{array}{r}
1[10] 9 \\
+\quad 1 \\
\hline 1[10] 10 \Rightarrow 2[10] 0 \Rightarrow 20 .
\end{array}
$$

Hi pot haver algun xiquet o xiqueta que tinga dubtes per entendre que $20>19$ perquè 9 és major que 0 , cal reflexionar que ho és perquè hi ha una desena més, un agrupament més que no pas en 19 . També podrien trobar ajuda en els materials comparant 
les peces que representen cada nombre i pensant sobre el seu significat i el seu valor: dues barres tenen més valor que una barra i nou cubs, o bé dues boles a la segona vareta valen més que una bola a la segona i nou a la primera (figures 32 i 33).

A mesura que es van construint els nombres es va veient com s'escriuen i com es 1ligen. Hi ha dues maneres diferenciades de treballar-ho que realment són com dos passos per arribar a la manera estàndard de fer una escriptura i lectura correctes:

1. Escriptura i lectura individualitzada o per unitats separades.

2. Escriptura i lectura global o estàndard.

La primera de les maneres, consisteix a denotar cadascuna de les xifres que componen el nombre, individualment segons el valor de l'ordre que hi ocupa. Exemple, en el cas del 23 escriurem 2[10] 3 i llegirem «dues desenes i tres unitats». Si no hi ha cap zero, en un primer moment es pot anomenar, però cal tendir a què no es faça.

En la segona de les maneres es tracta de llegir i escriure el nombre de manera global. Seguint l'exemple d'abans, escriurem «23» i llegirem «vint-i-tres».

A 2n de Primària s'introdueix el 100, com 99+1. Cal reflexionar al voltant d'aquest nombre que no és només el que segueix al 99, sinó el primer que necessita tres dígits per escriure'l.

Fins ara, sempre que s'afegia una unitat a un nombre conegut de dues xifres, apareixia un nou nombre que es representava també amb dues xifres. Va passar així amb el $12=11+1$, el $24=23+1, \ldots$, el $99=98+1$. No és el cas del cent. És evident que l'alumnat ja el pot conèixer per àmbits exteriors al treball realitzat a classe, o també a dins, quan el 100 ha aparegut per qualsevol motiu circumstancial. Però caldrà reflexionar que la seua representació està formada per tres dígits ja coneguts, un u i dos zeros.

Per recolzar l'aprenentatge dels nombres podem utilitzar materials estructurats, com els blocs multibase i els àbacs, ja coneguts. Així en el cas dels BM, partirem de 9 reglets i 9 cubs, i n'hi afegirem un altre cub. Segons hem vist en la construcció de la desena, en agrupar els deu cubs solts n'obtenim un nou reglet. Seguint l'esquema de funcionament de l'SND, caldrà agrupar els 10 reglets que ara tenim i substituir-los per una placa, que representa la unitat d'ordre següent. Aleshores el 100 simbolitzarà el que hi ha al material: 1 placa, 0 reglets i 0 cubs solts (figura 34).
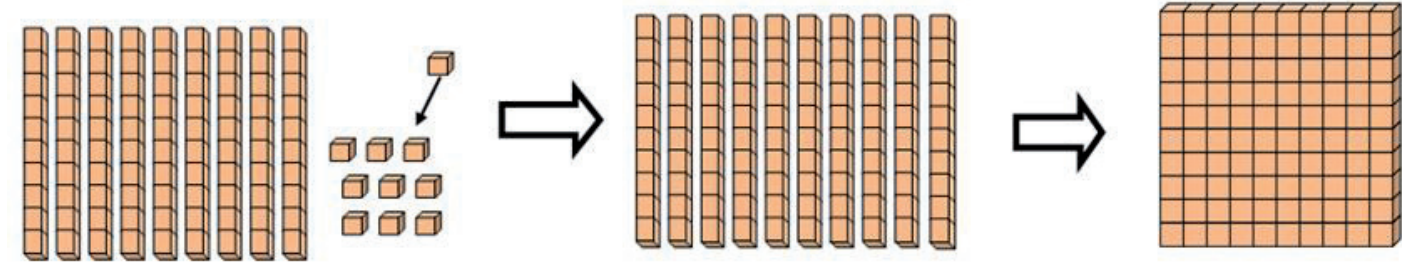

Figura 34. Construcció del $100 \mathrm{amb}$ BM 
Amb els àbacs, partirem d'un amb nou boles a la vareta de les desenes i nou a la de les unitats. Quan afegim una bola a les nou de la primera vareta per la dreta, obtenim deu boles que se substituiran per una a la vareta de les desenes. Queden deu boles a la vareta de les desenes i cap a la de les unitats. De manera anàloga al cas dels BM, substituirem les 10 desenes per una nova bola a la vareta següent de l'esquerra, que representa una unitat de tercer ordre. Per tant, el pas a l'expressió simbòlica és clar: el 100 representa el material perquè hi ha una bola a la tercera vareta, a comptar per la dreta, cap a la segona i cap a la primera (figura 35).

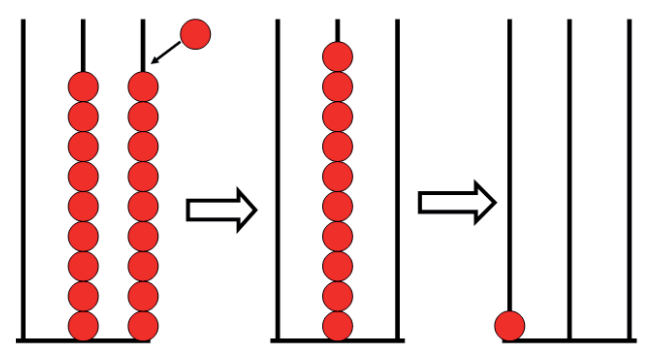

Figura 35. Construcció del $100 \mathrm{amb}$ àbacs

En qualsevol dels dos casos, cal fer un esforç per traslladar a l'escriptura numèrica el que s'està treballant amb els materials i s'ha verbalitzat amb l'alumnat. En tot aquest procés poden aparèixer representacions semblants a les següents:

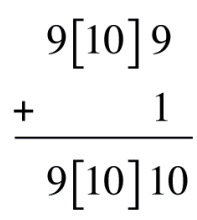

Com que estem a 2n curs d'Educació Primària i s'ha treballat ja l'addició, no és novetat la simbologia que apareix. Ràpidament s'adonaran que no és una representació correcta, i recolzant-se en el material s'arribarà a:

$$
10[10] 0
$$

Continuant amb l'esquema de funcionament de l'SND, caldrà substituir en la representació numèrica les deu unitats de segon ordre per una del tercer, com hem fet al material i expressarem el 100 amb l'ajuda de les unitats separades, si és necessari, de la manera següent:

$$
1[100] 0[10] 0
$$

Com que és una unitat d'ordre nou, de manera anàloga a la desena, cal treballar els quatre aspectes següents:

- Nom: centena

- Valor: 10 desenes (100 unitats)

- Escriptura: 100

- Lectura: 100 
La continuació del treball anterior és construir els nombres següents afegint unitats al 100. Al llarg de 2n de Primària cal arribar fins a la construcció del 999 associant el treball amb situacions en les quals apareguen els diferents nombres de tres xifres. S'aniran construint amb les ajudes necessàries i es veurà com s'escriuen, com es lligen... Per exemple, a partir de la necessitat de saber quant d'alumnat hi ha entre les sis classes de l'etapa de Primària per encarregar màscares per al carnaval, es planteja esbrinar l'expressió correcta del nombre corresponent. Davant la dificultat d'ajuntar-los en aquest precís moment, la mestra els ofereix una quantitat de cubs dels BM equipotent a la quantitat d'alumnes que volen comptabilitzar (147 en aquest cas). Els demana que els agrupen intercanviant cubs per reglets i reglets per plaques quan siga necessari, fins a arribar a l'expressió buscada, que serà la que apareix en la figura 36.

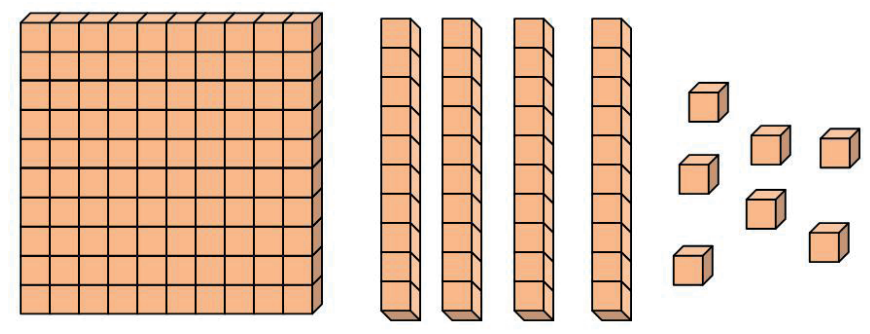

Figura 36. Representació de 147 amb BM

En cas que el material que s'utilitze a l'aula siguen els àbacs, es partirà de 147 boles i un àbac obert. Cada vegada que situen 10 boles a la vareta de les unitats, les substitueixen per 1 a la de les desenes. De la mateixa manera, quan hi haja 10 boles a la vareta de les desenes se substituiran per 1 a la de les centenes, fins a arribar a tenir la representació final, que serà la que apareix en la figura 37.

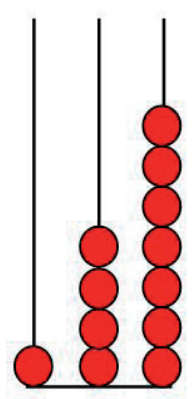

Figura 37. Representació de 147 amb àbacs

Caldrà tenir una especial atenció en el pas de 109 a 110, i ajudant-nos dels materials didàctics i les posteriors verbalització i simbolització s'intentarà solucionar. En aquests casos, sols cal reflexionar amb l'alumnat sobre la construcció d'una nova desena. Els següents passos, de 119 a 120, 129 a $130 \ldots$ no solen tenir problemes.

Al que sí que caldrà dedicar temps és al pas de 199 a 200, on s'haurà de reflexionar amb l'alumnat davant la construcció d'una nova centena, que sorgirà en el moment que s'afig una unitat al 199 i es genere un grup de deu desenes. En les figures 38 i 39 es mostren les construccions del 200 amb BM i àbacs, respectivament. 

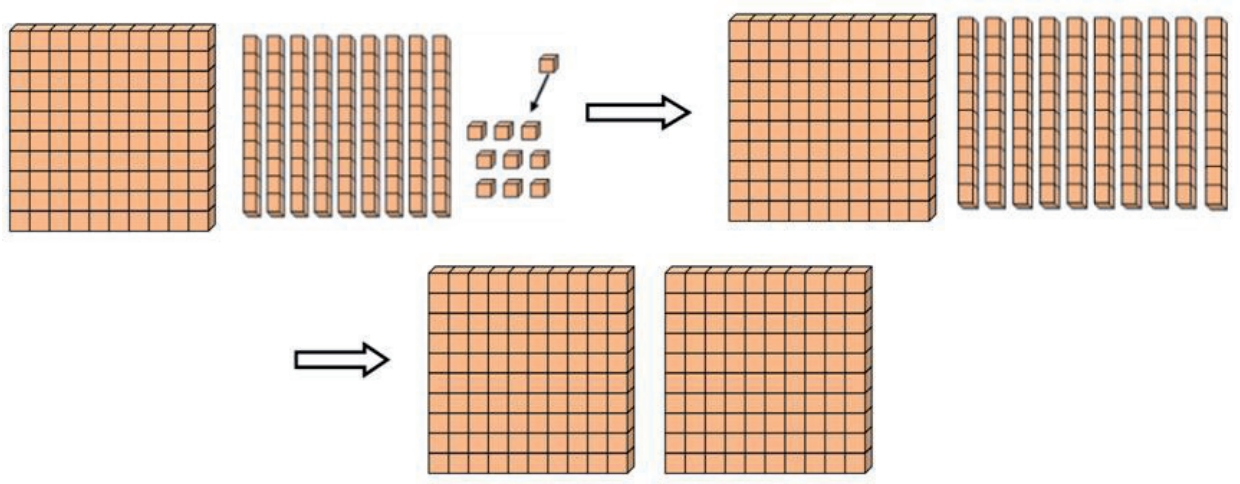

Figura 38. Construcció del 200 amb BM

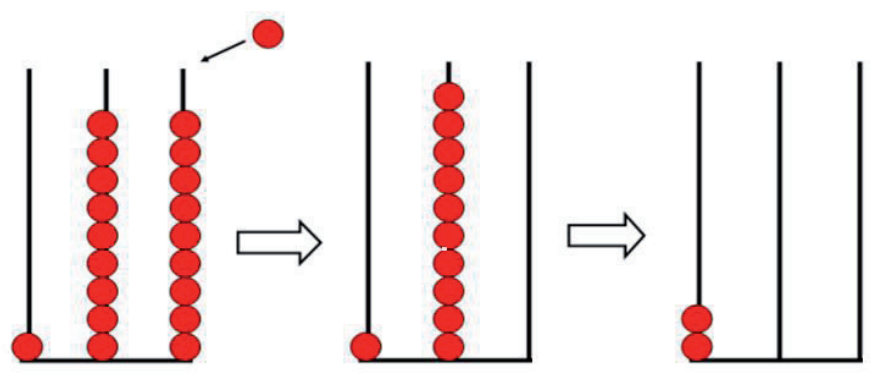

Figura 39. Construcció del 200 amb àbacs

En qualsevol dels dos casos, cal fer un esforç per traslladar a l'escriptura numèrica el que s'està treballant amb els materials i s'ha verbalitzat amb l'alumnat, s'obté d'aquesta manera la representació del nou nombre:

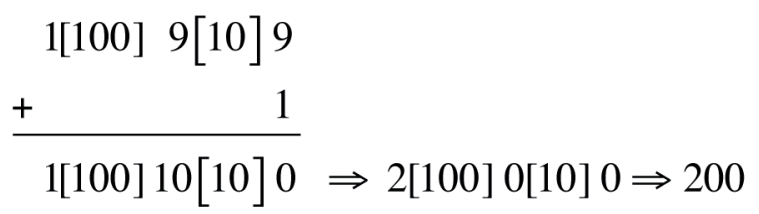

Les expressions numèriques amb unitats separades s'usaran, mentre siga necessari, per facilitar a l'alumnat la comprensió de la construcció dels nombres. A més, es treballarà l'escriptura i la lectura dels nombres d'acord amb les consideracions esmentades anteriorment (amb unitats separades i de manera estàndard).

Així s'arribarà al final del primer cicle fins al 999, i seran capaços d'escriure qualsevol nombre del 0 al 999.

A $3 r$ de Primària s'introdueix el 1.000, com $999+1$. Cal reflexionar al voltant d'aquest nombre que no és només el que segueix al 999, sinó el primer que necessita quatre dígits per escriure'l.

Fins ara, sempre que s'afegia una unitat a un nombre conegut de tres xifres, apareixia un nou nombre que es representava també amb tres xifres. Va passar així amb el $137=136+1$, el $245=244+1, \ldots$, el $999=998+1$. No és el cas del mil. És evident que l'alumnat ja el pot conèixer per àmbits exteriors al treball realitzat a classe, o també a dins, quan el 1.000 ha aparegut per qualsevol motiu 
circumstancial. Però caldrà reflexionar que la seua representació està formada per quatre dígits ja coneguts, un u i tres zeros.

De manera anàloga a la desena i a la centena, si es considera necessari i per recolzar l'aprenentatge dels nous nombres, podem utilitzar els materials didàctics habituals. Així en el cas dels BM, partirem de 9 plaques, 9 reglets i 9 cubs i n'afegirem un altre cub. Segons hem vist en les construccions de la desena i la centena, en agrupar els deu cubs solts n'obtenim un nou reglet que amb els nou que ja teníem formen una placa. Seguint l'esquema de funcionament de 1'SND, caldrà agrupar les 10 plaques que hem aconseguit i substituir-les per un bloc, que representa la unitat d'ordre següent. Aleshores el 1.000 simbolitzarà el que hi ha al material: 1 bloc, 0 plaques, 0 reglets i 0 cubs solts (figura 40).

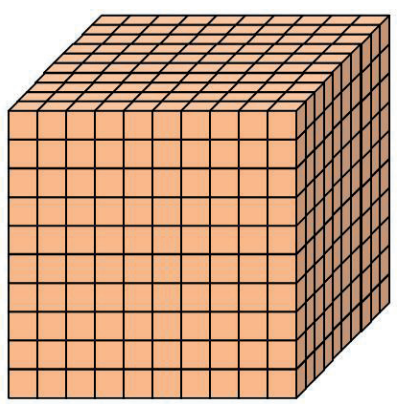

Figura 40. Representació del 1.000 amb BM

Amb els àbacs, partirem d'un amb nou boles a la vareta de les centenes, nou en a de les desenes i nou a la de les unitats. Quan afegim una bola a les nou de la primera vareta per la dreta, obtenim deu boles que se substituiran per una a la de les desenes. Queden deu boles a la vareta de les desenes i cap a la de les unitats. De manera anàloga al cas dels BM, substituirem les 10 desenes per una nova bola a la vareta següent de l'esquerra, que representa una unitat de tercer ordre. En aquest moment hi ha deu boles a la de les centenes. Es fa necessari transformar aquestes en una altra a la següent vareta, i s'obté una unitat d'ordre següent, el quart. Per tant, el pas a l'expressió simbòlica és clar: el 1.000 representa el material perquè hi ha 1 bola a la quarta vareta, a comptar per la dreta, cap bola a la tercera, cap a la segona i cap a la primera (figura 41).

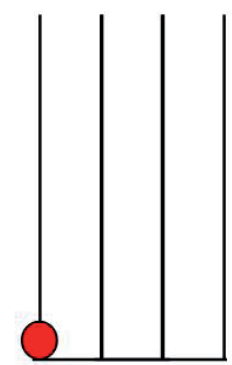

Figura 41: Representació del 1.000 amb àbacs

En qualsevol dels dos casos, cal fer un esforç per traslladar a l'escriptura numèrica el que s'està treballant amb els materials i s'ha verbalitzat amb l'alumnat, i s'obté d'aquesta manera la representació del nou nombre: 
Com que és una unitat d'ordre següent, de manera anàloga als anteriors, cal treballar de nou els quatre aspectes:

- Nom: unitat de miler

- Valor: 10 centenes (100 desenes o 1.000 unitats)

- Escriptura: 1.000

- Lectura: 1.000

Matemàticament, per indicar aquest ordre d'unitats, s'usa un punt entre la quarta i la tercera xifra. Cal notar que una expressió d'aquest tipus a dins d'una oració escrita pot induir a error. Per això des d'un punt de vista filològic es recomana no posar el punt en aquests casos.

Anàlogament al que s'ha desenvolupat per les desenes i les centenes es construeixen els nombres de quatre xifres superiors a 1.000, amb l'ajuda dels materials didàctics quan siga necessari, i es treballa l'escriptura i la lectura dels nombres d'acord amb les consideracions esmentades anteriorment (amb unitats separades si escau i de manera estàndard).

Al llarg del 2n cicle s'han de treballar també els nombres de cinc i sis xifres fins arribar a 999.999, insistint en la formació de les unitats dels ordres següents a la unitat de miler: desenes de miler i centenes de miler, i amb l'ajuda dels materials didàctics si es considera necessari. Al 3 r cicle s'acaba de desenvolupar l'sND, i es treballen els nombres a partir del milió.

\section{Descompondre els nombres naturals atenent al valor posicional de les xifres, $i$ arribar a expressar-los en forma polinòmica}

Al mateix temps que es treballa la capacitat anterior i relacionat amb la lectura i l'escriptura dels nombres, aprofitarem el coneixement de l'addició que l'alumnat va adquirint des del 1r curs de l'etapa per descompondre els nombres fent servir aquesta operació i el valor posicional de les xifres que el componen.

Aquesta forma de representar els nombres ens pot ajudar, durant els primers cursos de Primària, en el treball de desenvolupament del càlcul mental i també en l'ensenyament aprenentatge dels algorismes de les operacions.

Així, començarem amb els nombres de dues i tres xifres acompanyant les diferents maneres de escriure'ls i llegir-los treballades anteriorment amb la seua representació additiva:

$$
\begin{gathered}
7[10] 8=70+8 \text { о } 78=70+8 \\
6[100] 7[10] 8=600+70+8 \text { o } 678=600+70+8 .
\end{gathered}
$$


Els primers passos d'aquest treball poden donar-se amb l'ajuda dels materials didàctics que hem utilitzat. Caldrà observar l'equivalència entre els valors de les diferents peces de la representació dels nombres amb els BM i les diferents representacions numèriques que els corresponguen, així com entre els valors de les boles segons la seua posició en el cas dels àbacs i les representacions numèriques associades.

En el $2 \mathrm{n}$ cicle, quan treballem nombres més grans, utilitzarem també aquesta forma de representació fins que l'alumnat conega la multiplicació per la unitat seguida de zeros. A partir d'aquest moment, cada xifra anirà acompanyada de l'u amb tants zeros com siguen necessaris per indicar l'ordre de la unitat que representa, és a dir, per ressaltar el valor posicional de cadascuna de les xifres. Arribarem així a una representació additivomultiplicativa que canviarà una expressió del tipus següent:

per una del tipus:

$$
45.678=40.000+5.000+600+70+8
$$

$$
45.678=(4 \times 10.000)+(5 \times 1.000)+(6 \times 100)+(7 \times 10)+8 .
$$

Treballarem amb aquestes expressions fins que, en el 3r cicle de Primària, s'introduïsca la potenciació, amb la qual podrem transformar les darreres expressions en d'altres que utilitzen les potències de la base de l'SND per indicar el valor posicional de les xifres que componen els nombres. Així, l'expressió anterior es convertirà en:

$$
45.678=\left(4 \times 10^{4}\right)+\left(5 \times 10^{3}\right)+\left(6 \times 10^{2}\right)+(7 \times 10)+8 .
$$

Com s'ha esmentat en el punt 3.2.2, aquesta expressió s'anomena descomposició polinòmica d'un nombre i ens serveix per reforçar amb l'alumnat, d'una manera més clara i sistemàtica que les representacions anteriors, el valor intrínsec que té cadascuna de les xifres en un nombre qualsevol segons la posició.

Mentre els xiquets i xiquetes no coneguen la jerarquia de les operacions, caldrà utilitzar els parèntesis per clarificar les expressions. Una vegada s'haja treballat en el $3 r$ cicle, se'n pot prescindir i escriure les expressions polinòmiques de la manera següent:

$$
45.678=4 \times 10^{4}+5 \times 10^{3}+6 \times 10^{2}+7 \times 10+8 .
$$

\section{Ordenar nombres naturals. Introduir el vocabulari i la notació corresponents. Comptar progressivament i regressiva}

En aquesta capacitat completarem el coneixement dels nombres naturals estudiant el seu aspecte ordinal i treballant, per tant, com estan ordenats tant des del punt de vista procedimental, com des del que es refereix a la nomenclatura.

Haurem de començar en el 1r cicle amb el repàs de l'ordenació dels nombres d'una xifra que s'ha treballat a Educació Infantil. Aprofitarem situacions quotidianes de 
comparació numèrica per treballar amb l'alumnat les regles d'ordenació dels nombres. Per exemple, cal repartir fulls amb exercicis. Hem fet 32 fotocòpies i a classe hi ha 23 alumnes. Se'ls demana que contesten si sobraran fotocòpies per a l'alumnat que no ha vingut avui a classe, és a dir, volem saber si 32 és major o menor que 23.

La manera inicial d'esbrinar-ho serà mitjançant una correspondència un a un entre l'alumnat i les fotocòpies, per la qual podran contestar a la pregunta amb la seguretat de saber que sí sobraran fotocòpies per als xiquets i xiquetes que no han vingut avui.

Posteriorment caldrà que es plantege a classe la pregunta següent: «Podríem saber quin dels dos nombres és major comparant-ne les expressions numèriques?». Per tal de respondre ens podem ajudar de l'anàlisi de la representació dels dos nombres amb els BM i/o els àbacs, mitjançant la qual observarem les diferents xifres que els componen i els seus valors en funció de les posicions que ocupen, arribanran a la conclusió que 32 és major perquè té tres desenes, mentre que 23 només en té dues.

La realització de més comparacions d'aquests tipus i la reflexió sobre els diferents resultats que van obtenint ens ha de conduir al descobriment de les dues regles següents:

- Si un nombre natural té més quantitat de xifres que un altre, el primer és major que el segon perquè conté unitats d'ordre superior.

- Si dos nombres tenen la mateixa quantitat de xifres, caldrà comparar aquestes començant d'esquerra a dreta per les unitats de major ordre, fins a arribar a dues xifres que siguen diferents. El nombre que continga la xifra més alta d'aquestes dues serà el major.

Aquestes regles es repassaran i s'utilitzaran en els següents cicles de manera habitual per ordenar parelles de nombres naturals de qualsevol quantitat de xifres. Així, sent capaços d'ordenar qualsevol parella de nombres, podrem arribar a tenir ordenada la sèrie numèrica dels nombres naturals que es treballen en cadascun dels cursos de l'etapa.

Com a complement d'aquest treball, haurem d'introduir, al llarg de l'etapa, el vocabulari i la notació associades als ordinals. Per tant, en el 1r cicle, revisarem amb l'alumnat els noms i les notacions dels nou primers ordinals que coneixen d'Educació Infantil i afegirem els dels següents: desè (10è), onzè (11è), dotzè (12è), tretzè (13è), etc., tenint en compte que alguns ordinals de les potències de 10 es poden escriure i llegir també acabades en -èsim: centèsim, mil·lèsim... Caldrà tenir especial atenció a les diferències entre el valencià i el castellà (se suposen conegudes pel lector). Caldrà també introduir-hi els signes que ens permeten representar les comparacions entre els nombres $(>,<,=, \neq)$.

Respecte de comptar, cal fer comptatges d' 1 en 1 , de 2 en $2, \ldots$, de 9 en 9, que milloraran el seu coneixement de la sèrie numèrica natural i amb la intenció que posteriorment els valga per memoritzar la taula de multiplicar i de 10 en 10, de 100 en $100 \ldots$, per reforçar l'sND. 


\section{Reflexionar sobre els diferents usos dels nombres naturals en situacions quotidianes}

L'objectiu que ens marquem en el desenvolupament d'aquesta capacitat és que l'alumnat observe la presència quasi constant dels nombres en la seua vida i que en reconega la utilitat en qualsevol situació quotidiana.

Treballarem al llarg de tots els cursos de Primària a partir de converses entre ells i elles, lectures de diferents textos, explicacions de diferents situacions, produccions escrites per l'alumnat..., per fer-los reflexionar al voltant del moment en què apareixen els nombres i quina és la seua importància en cada cas. Com a activitat complementària podem intentar desenvolupar el treball de l'aula durant un matí sense utilitzar cap nombre, per tal que s'adonen de la dificultat que suposaria prescindir-ne.

La intenció última és que els xiquets i xiquetes usen els nombres, que s'adonen que els estan usant $i$ que sàpiguen trobar-los en situacions en les quals poden aparèixer, així com reconèixer els diferents usos que se'n fa: comptar, ordenar, mesurar, operar i identificar o codificar.

\section{Llegir i escriure quantitats en el sistema de numeració romà}

El sistema de numeració romà ha perdurat en la nostra societat en usos i contextos molt definits com són: notació dels segles, capítols de llibres, esdeveniments (jornades, congressos...), acompanyant els noms d'alguns personatges importants...

Això justifica la seua introducció cap al $3 \mathrm{r}$ cicle de Primària. Caldrà que coneguen els símbols numèrics i els valors corresponents, així com les regles que regeixen el seu ús en la representació dels nombres (vegeu 3.1).

Per poder interpretar $\mathrm{i}$ produir representacions numèriques en què apareguen nombres romans, hauran de treballar a classe l'equivalència entre aquest sistema i l'SND, per ser capaços de traslladar d'un sistema a un altre quantitats que arriben fins als milers.

\section{Introduir el sistema de numeració sexagesimal}

El sistema de numeració sexagesimal ha esdevingut des de l'Antiguitat fins als nostres dies en dos contextos molt concrets: la mesura del temps i la mesura de l'amplitud angular. És cert que, tant en un àmbit com en l'altre, quan una mesura concreta queda expressada en els diferents ordres de les unitats, totes aquestes no es troben en el sistema sexagesimal. Així, per exemple, en el cas del temps, si parlem de 2 dies 4 h 30 min $8 \mathrm{~s}$, els minuts i els segons es troben expressats en el sistema sexagesimal, però els dies i les hores no. De la mateixa manera $45^{\circ} 23^{\prime}$ 
45', en la mesura de l'amplitud angular, els minuts i els segons estan expressats en el sistema sexagesimal, però els graus no.

Dins del bloc de magnitud i mesura es troben aquests àmbits per treballar amb els alumnes de Primària, i és per això que en el $3 \mathrm{r}$ cicle cal fer un treball del sistema sexagesimal per poder concretar-lo als contextos esmentats (vegeu 3.1).

Tant en el temps com en l'amplitud angular, les mesures poden estar expressades com en els exemples que s'han il-lustrat en aquest apartat (forma incomplexa), o bé en l'SND. Per aquesta última, cal triar un ordre concret i transportat la resta d'ordres a aquest (forma complexa). 


\section{TEMA 2}

\section{Operacions amb Nombres Naturals}

En aquest tema es treballa el tractament didàctic de l'addició, la subtracció, la multiplicació i la divisió amb nombres naturals a l'aula de Primària mitjançant una proposta didàctica de quatre fases per al seu desenvolupament. D'acord amb aquestes, es parteix de la connexió de l'operació amb situacions reals per donar-li significat. Es continua simbolitzant matemàticament el resultat de les corresponents accions amb els objectes reals i treballant els algorismes a partir de les idees prèvies de l'alumnat $\mathrm{i}$ de les seues propostes personals per a les diferents operacions aritmètiques. També s'aborden la resolució i la invenció de problemes associats a cada operació.

\section{Introducció}

Sembla lògic pensar que l'immediat, una vegada s'ha introduït el concepte de nombre i el de SND, hauria de ser el treball d'operar amb nombres naturals i signes aritmètics. Però aquesta tasca requereix un nivell d'abstracció superior al que cal per analitzar adequadament les accions amb objectes, que poden ser més intuïtives i, probablement, no se les troba l'alumnat a l'escola per primera vegada.

Es pot afirmar, per tant, que hi ha dos tipus de situacions en referència amb el fet «d'operar». Unes serien extraescolars, per tant, naturals, intuïtives i sovint necessàries ( $\mathrm{s}$ 'hauria d'anomenar també aquestes accions càlcul mental, pel fet que no s'ha de disposar en el moment de llapis i paper). D'altres són les escolars, on molts dels esforços s'encaminen a esbrinar mecanismes o a construir i aprendre els algorismes (conjunt sistemàtic d'accions que condueixen a l'obtenció d'un resultat) que permeten operar. Dues situacions ben diferents a priori i amb una resposta també ben diferent per part de l'alumnat.

L'escola, d'una banda, ha de solucionar aquesta situació de gran dicotomia; de l'altra, ha de ser el lloc on es canalitze i respecte l'aprenentatge que el xiquet fa fora de l'aula. Al mateix temps ha d'afavorir que aquest s'integre en el coneixement o «reconeixement» de les operacions aritmètiques que cal desenvolupar a classe. I, és clar, l'objectiu és dotar aquest alumne de més eines, de més capacitats, per tal de resoldre els nous problemes que la realitat extraescolar li planteja. Per tant, l'esquema se simplifica d'aquesta manera: cal partir d'accions de la realitat, 
treballar les abstraccions d'aquestes accions per dotar-los de capacitats que, una vegada assolides, els permeten resoldre noves situacions de la realitat.

L'objectiu de l'escola, doncs, estarà cobert quan l'alumnat que siga capaç d'operar amb signes matemàtics reconega l'íntima relació que hi ha entre les accions extraescolars i les escolars. Cal esmentar que la realitat de vegades és ben diferent i l'aprenentatge escolar no garanteix l'eliminació dels entrebancs entre aquestes dues situacions. Així, el repte serà trobar la manera d'apropar al coneixement dels xiquets i les xiquetes els procediments que els permetran operar i que tradicionalment han pogut ser algorismes foscos allunyats de la intuïció.

Les formalitzacions de l'addició i la multiplicació de Nombres Naturals s'han tractat ja en el tema anterior. No es presenten les de la subtracció i la divisió perquè no són operacions internes, però en el desenvolupament del tema estudiarem la seua relació amb la complementació i les particions de conjunts.

\section{Les operacions amb Nombres Naturals a l'aula de Primària}

\subsection{Fases per a l'ensenyament-aprenentatge de les operacions}

Per al desenvolupament del procés d'ensenyament-aprenentatge (en endavant E-A) de les operacions amb Nombres Naturals en les aules d'Educació Primària, proposem les fases següents:

1. Exposar el significat de l'operació partint de situacions reals i de la seua relació amb la teoria de conjunts, perquè l'operació tinga sentit per a l'alumnat.

2. Traduir simbòlicament l'operació.

3. Automatitzar l'operació. Conèixer l'algorisme, saber utilitzar-lo.

4. Resoldre i inventar situacions problemàtiques relacionades amb l'operació.

Quan treballem aquestes fases, l'expressió numèrica de l'operació serà la transcripció de les manipulacions dels xiquets. Cal tenir en compte la dificultat que suposa per a l'alumne passar d'una acció concreta amb els objectes a la seua expressió simbòlica. Per exemple, entre la situació de reunir un conjunt de tres pomes i un altre de sis, i l'expressió $3+6$, s'han de salvar una sèrie de dificultats degudes als significats diferents que tenen per a ells i elles les dues accions. La utilització de signes matemàtics per escriure les operacions, per simbolitzar-les, exigeix una preparació prèvia mitjançant algunes etapes successives. En primer lloc, repetirem la manipulació amb els objectes les vegades que considerem necessàries. Al mateix temps, treballarem la translació al llenguatge verbal i demanarem als xiquets que ens conten què han fet, les seues reflexions, els seus pensaments. Superat satisfactòriament aquest moment, podem introduir la translació al llenguatge gràfic $\mathrm{i}$ a la seua expressió mitjançant símbols i signes matemàtics. 
El problema del mestre és aconseguir que els alumnes siguen capaços de relacionar les accions reals o imaginades amb la seua traducció al llenguatge matemàtic, que utilitza els seus signes propis i les seues fórmules. No es tracta, doncs, de fer comprendre als xiquets i xiquetes el significat de l'operació després d'haver-los ensenyat a calcular-la, sinó al contrari, cal que utilitzen una operació, en la mesura que comprenguen el que aquesta expressa i significa. Al mateix temps, hem de treballar la reversibilitat de l'operació en el sentit de Piaget, és a dir, cal que l'alumnat siga capaç d'inventar situacions problemàtiques que es resolguen amb l'operació proposada.

En els aspectes referents a la construcció i el descobriment dels algorismes estàndard de les operacions que s'estudien en Primària, començarem analitzant els processos i estratègies personals de càlcul inventats per l'alumnat en les diferents situacions problemàtiques que es plantegen a l'aula (Gallego i altres, 2005). A continuació, i dins del treball de reflexió associat a aquesta anàlisi, dirigirem l'atenció cap a la necessitat de conèixer l'estructura $i$ el funcionament que tenen universalment els algorismes esmentats i que són els que utilitzen les restants persones que es troben en l'entorn de l'alumnat. En aquest sentit i per evitar aprenentatges mecànics i memorístics, el nostre treball pretén ajudar els xiquets i les xiquetes a descobrir de manera raonada quines són les regles i quins els passos que regeixen aquests algorismes, partint de situacions reals, de la manipulació de materials didàctics adequats $i$ arribant a les expressions numèriques corresponents posant l'accent en les seues relacions i en les seues regularitats.

\subsection{Capacitats que cal desenvolupar a l'aula de Primària}

El treball en Educació Primària referent a les operacions amb Nombres Naturals, té com a objectiu contribuir a desenvolupar en l'alumnat les capacitats que s'expressen en la llista següent la finalitat de les quals és afavorir el desenvolupament de la competència matemàtica dels xiquets i les xiquetes, i representar una ajuda per a la resta de competències de l'Educació Primària.

Hem organitzat les capacitats en funció de les quatre operacions treballades. Per a cadascuna l'ordre proposat és seqüencial, és a dir, progressiu i d'intensitat de dificultat creixent:

\section{A. Addició}

A. 1. Construir el concepte de addició a partir de la unió de dos conjunts disjunts, expressant els cardinals respectius.

A. 2. Utilitzar els signes «+» $\mathrm{i} \ll=»$ per simbolitzar addicions. Identificar els termes i els signes de l'addició.

A. 3. Realitzar addicions de nombres a partir de la unió de conjunts disjunts.

A. 4. Construir la taula de l'addició de nombres naturals.

A. 5. Comprovar experimentalment les propietats commutativa i associativa de l'addició. Reconèixer i aplicar aquestes propietats. 
A. 6. Descobrir l'algorisme de l'addició «sense portar-ne» i utilitzar-lo per realitzar addicions «sense portar-ne» amb els sumands disposats verticalment i horitzontalment.

A. 7. Descobrir l'algorisme de l'addició «portant-ne» i utilitzar-lo per realitzar addicions «portant-ne» amb els sumands disposats verticalment $i$ horitzontalment.

A. 8. Desenvolupar l'agilitat mental en el càlcul de l'addició.

A. 9. Resoldre i inventar situacions problemàtiques relacionades amb l'addició.

A.10. Realitzar exercicis pràctics d'addicions en el sistema de numeració sexagesimal.

\section{B. Subtracció}

B. 1. Construir la idea de subtracció a partir del complementari d'un subconjunt d'un conjunt donat, expressant els cardinals respectius.

B. 2. Utilitzar els signes «-» $\mathrm{i} \ll=»$ per simbolitzar subtraccions. Identificar els termes i els signes de la subtracció.

B. 3. Realitzar subtraccions de nombres a partir de la complementació de conjunts.

B. 4. Associar la subtracció amb unions de conjunts disjunts en les quals en falte un, dels conjunts esmentats, expressant els cardinals respectius.

B. 5. Completar addicions en les quals falte un sumand i simbolitzar aquestes addicions incompletes usant els signes $«-\gg \mathrm{i} «=»$. Repassar els termes $\mathrm{i}$ els signes de la subtracció.

B. 6. Associar la subtracció amb la comparació dels cardinals de dos conjunts. Utilitzar els signes «-» $\mathrm{i} «=»$ per expressar numèricament la diferència entre els cardinals esmentats. Repassar els termes i els signes de la subtracció.

B. 7. Conèixer els resultats de les subtraccions bàsiques (les que es dedueixen de la taula de l'addició).

B. 8. Descobrir l'algorisme de la subtracció «sense portar-ne» i utilitzar-lo per realitzar subtraccions «sense portar-ne», amb el minuend i el subtrahend col·locats verticalment i horitzontalment.

B. 9. Descobrir l'algorisme «natural» de la subtracció «portant-ne» i utilitzar-ho per realitzar subtraccions «portant-ne», amb el minuend i el subtrahend col·locats verticalment i horitzontalment.

B.10. Descobrir l'algorisme «estàndard» de la subtracció «portant-ne» i utilitzarlo per realitzar subtraccions «portant-ne», amb el minuend i el subtrahend col·locats vertical i horitzontalment.

B.11. Desenvolupar l'agilitat mental en el càlcul de la subtracció.

B.12. Resoldre i inventar situacions problemàtiques relacionades amb la subtracció.

B.13. Realitzar exercicis pràctics de subtraccions en el sistema de numeració sexagesimal.

C. Multiplicació

C. 1. Construir la idea de multiplicació a partir de la unió de conjunts disjunts equipotents, expressar els cardinals respectius i simbolitzar les addicions de sumands iguals realitzades. 
C. 2. Utilitzar els signes $« x » \mathrm{i} \ll=»$ per expressar, mitjançant una multiplicació, una addició de sumands iguals. Identificar i utilitzar correctament els termes i els signes de la multiplicació.

C. 3. Realitzar multiplicacions de nombres utilitzant addicions de sumands iguals.

C. 4. Construir la taula de multiplicar.

C. 5. Descobrir l'algorisme de la multiplicació per una xifra i utilitzar-lo per realitzar multiplicacions en les quals augmente progressivament el nombre de xifres del multiplicand.

C. 6. Identificar nombres parells i imparells.

C. 7. Comprovar les propietats commutativa, associativa i distributiva de la multiplicació. Reconèixer i aplicar aquestes propietats.

C. 8. Descobrir l'algorisme de la multiplicació per 10, 100, 1.000... i utilitzar-lo per realitzar gràficament i mentalment multiplicacions per la unitat seguida de zeros.

C. 9. Descobrir l'algorisme de la multiplicació de dos nombres de diverses xifres i utilitzar-lo per realitzar multiplicacions de dificultat creixent.

C.10. Desenvolupar l'agilitat mental en el càlcul de la multiplicació.

C.11. Resoldre i inventar situacions problemàtiques relacionades amb la multiplicació.

C.12. Adquirir la noció de potència com a producte de factors iguals. Identificar la base i l'exponent d'una potència.

D. Divisió

D. 1. Construir la idea de divisió exacta utilitzant particions en les quals totes les parts siguen equipotents i expressar els cardinals que hi intervinguen. Simbolitzar aquestes particions utilitzant els signes $« x » i \ll=\rangle$.

D. 2. Canviar simbolitzacions de multiplicacions incompletes per d'altres que usen els signes «:» $\mathrm{i} \ll=»$. Identificar $\mathrm{i}$ utilitzar correctament els termes $\mathrm{i}$ els signes de la divisió exacta.

D. 3. Construir la idea de divisió entera utilitzant particions en les quals totes les parts menys una siguen equipotents i expressant els cardinals que hi intervinguen. Simbolitzar aquestes particions usant els signes $«+, \times,=»$.

D. 4. Simbolitzar divisions enteres usant la representació habitual. Identificar i utilitzar correctament els termes i els signes de la divisió entera.

D. 5. Realitzar divisions de nombres utilitzant particions de conjunts en parts equipotents.

D. 6. Descobrir l'algorisme de la divisió exacta i entera per una xifra i utilitzar-lo per realitzar divisions exactes i enteres en les quals augmente progressivament el nombre de xifres del dividend.

D. 7. Descobrir l'algorisme de la divisió per dues xifres i utilitzar-lo per realitzar divisions en les quals augmente progressivament el nombre de xifres del dividend. Automatitzar la divisió en tots els casos.

D. 8. Reconèixer les relacions que existeixen entre dividend, divisor, quocient $\mathrm{i}$ residu i utilitzar-les com a «prova de la divisió».

D. 9. Desenvolupar l'agilitat mental en el càlcul de la divisió.

D.10. Resoldre i inventar situacions problemàtiques relacionades amb la divisió. 


\subsection{Desenvolupament de les capacitats}

\section{A. Addició}

La noció de addició de nombres naturals va lligada al concepte de conjunt; per tant, és vàlid el que s'ha vist en el tema anterior i que fa referència a aquest concepte.

Atenent a la definició, l'addició és l'operació que ens permet calcular la suma de dos nombres, entenent que aquesta suma és el cardinal del conjunt que resulta d'unir dos conjunts disjunts que tenen com a cardinals els nombres que sumarem.

A.1. Construir el concepte de addició a partir de la unió de dos conjunts disjunts, $i$ expressar els cardinals respectius

En aquesta capacitat desenvolupem el treball corresponent a la primera de les fases d'E-A de l'addició, que es realitza en el 1r curs de l'etapa.

Cal partir d'activitats pràctiques i manipulatives per recrear situacions que puguen identificar ràpidament. Les situacions que hem de presentar són aquelles en les quals, en l'estat final, hi ha un augment de la quantitat d'elements respecte de l'estat inicial.

Si per pintar una caseta els deixem damunt la taula, en primer lloc, tres colors $i$ després dos, i la pregunta és «quants n'hi ha?», el que faran és comptar 1, 2, 3..., i la resposta serà «cinc elements». No han fet mentalment «dos més tres igual a cinc», sols han comptat.

Verbalment diran «tinc tres colors i me'n donen dos més, aleshores tinc cinc colors». En posteriors repeticions de les accions, la verbalització anirà evolucionant passant per expressions com ara «en tinc tres i me'n donen dos més, aleshores en tinc cinc» fins a arribar a «tres més dos són cinc».

És convenient que l'alumnat acompanye la manipulació i la verbalització amb una representació gràfica (figura 42) del que ha ocorregut amb el material, en la qual a més, apareguen els nombres involucrats.

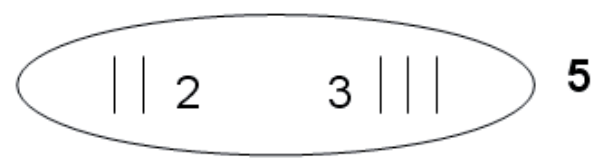

Figura 42. Representació de l'agrupament de 2 i 3

Aquesta tasca constituirà el primer pas per valorar la importància d'aprendre a resoldre aquestes situacions sols amb els nombres, sense que siga necessari tenir 
sempre a l'abast els objectes concrets que hi intervenen, i facilita així l'accés a la fase simbòlica. S'introduirà la paraula addició associada a les relacions numèriques que apareixen a partir d'aquestes accions manipulatives.

El final de la fase serà demanar als xiquets i xiquetes que siguen ells qui troben o reconeguen situacions de la seua vida personal que estiguen relacionades amb l'operació (diners de la vidriola, llepolies...).

\section{A.2. Utilitzar els signes «+» $i \lll=»$ per simbolitzar addicions. Identificar els termes i signes de l'addició}

Continuant en el 1r curs, una vegada realitzades les accions anteriors i coneguda la paraula addició, és el moment de passar a la segona fase d'E-A de l'operació, introduir els símbols «+»》 i «=»; aleshores, l'enunciat verbal «tres més dos són cinc» es canvia per l'enunciat numèric « $\ll+2=5 »$, en un primer moment de manera

horitzontal, que canviarem posteriorment a la disposició vertical +2 per facilitar més endavant l'aprenentatge de l'algorisme.

A més a més, s'ha de conèixer la nomenclatura específica: el 3 i el 2, que són els termes de l'operació, s'anomenen sumands, i el 5, que és el resultat, s'anomena suma. El signe «+» es llegeix més, i el signe «=», igual.

En el moment que s'hagen conegut els termes i els signes de la resta d'operacions, haurem de comprovar que l'alumnat els identifica i diferencia correctament.

\section{A.3. Realitzar addicions de nombres a partir de la unió de conjunts disjunts}

És important que després d'haver introduït l'expressió simbòlica de l'operació, aquesta no es desconnecte de les accions amb les quals es relaciona. Per això, també en el 1r curs i en moments posteriors al treball de la capacitat anterior, caldrà mostrar-los expressions simbòliques d'addicions que hauran de resoldre mitjançant reunions de diferents objectes.

Aquest és un treball invers al que es realitza en les dues capacitats anteriors, en les quals l'alumnat avançava des de les accions amb els objectes fins a les expressions numèriques de les situacions.

Si els xiquets i xiquetes són capaços de trobar els resultats de les addicions propostes sense recórrer als objectes, poden resoldre-les numèricament d'aquesta manera, però haurem de reflexionar amb ells i elles sobre el significat de l'operació $i$ sobre la seua relació inequívoca amb situacions en què s'afegeixen uns elements a d'altres i s'obté com a resultat un nombre major que els originals. 


\section{A.4. Construir la taula de l'addició de nombres naturals}

Simultàniament al treball de manipulació d'objectes quotidians, els quals hauran agrupat, comptat, etc., de diverses maneres i per tal de recollir els resultats de les addicions realitzades, poden emplenar una graella en la qual es recullen les sumes bàsiques i que dóna per resultat la taula següent:

\begin{tabular}{|c|c|c|c|c|c|c|c|c|c|}
\hline+ & 1 & 2 & 3 & 4 & 5 & 6 & 7 & 8 & 9 \\
\hline 1 & 2 & 3 & 4 & 5 & 6 & 7 & 8 & 9 & 10 \\
\hline 2 & 3 & 4 & 5 & 6 & 7 & 8 & 9 & 10 & 11 \\
\hline 3 & 4 & 5 & 6 & 7 & 8 & 9 & 10 & 11 & 12 \\
\hline 4 & 5 & 6 & 7 & 8 & 9 & 10 & 11 & 12 & 13 \\
\hline 5 & 6 & 7 & 8 & 9 & 10 & 11 & 12 & 13 & 14 \\
\hline 6 & 7 & 8 & 9 & 10 & 11 & 12 & 13 & 14 & 15 \\
\hline 7 & 8 & 9 & 10 & 11 & 12 & 13 & 14 & 15 & 16 \\
\hline 8 & 9 & 10 & 11 & 12 & 13 & 14 & 15 & 16 & 17 \\
\hline 9 & 10 & 11 & 12 & 13 & 14 & 15 & 16 & 17 & 18 \\
\hline
\end{tabular}

Caldrà aconseguir que l'alumnat del $1 \mathrm{r}$ curs siga capaç de memoritzar aquests resultats per facilitar els càlculs amb l'addició.

\section{A.5. Comprovar experimentalment les propietats commutativa $i$ associativa de l'addició. Reconèixer i aplicar aquestes propietats}

Dues propietats de l'addició que es poden treballar molt fàcilment són les anomenades commutativa i associativa. En tots dos casos la introducció a l'aula es duria a terme de manera gradual, amb exemples de nombres que representen poca quantitat i augmentant-ne la dificultat a poc a poc.

És probable que en construir la taula l'alumnat de 1r cicle observe que les addicions amb sumands iguals però canviats d'ordre donen el mateix resultat. Amb la intenció de confirmar aquestes observacions i generalitzar-les en la mesura de les seues possibilitats, comprovarem que això ocorre amb totes les addicions que poguérem fer. Els exemples que s'utilitzaran tindran, en primer lloc, una fase manipulativa, on quedarà clar que agrupant de diferent manera dues quantitats d'objectes el resultat és el mateix i, posteriorment, una fase simbòlica. En l'exemple «dues pilotes més tres pilotes és la mateixa quantitat que tres mandarines i dues mandarines», resoldran $2+3=5$ i $3+2=5$. A continuació expressaran la igualtat de resultats de la manera següent: $2+3=5=3+2$ i per acabar, $2+3=3+2$.

L'absència de resultat en l'expressió simbòlica requereix un esforç mental més gran. Cal tenir en compte que si la lògica d'una operació és obtenir un resultat, en aquesta darrera manera d'expressar la situació real sembla no tenir importància. 
Aconseguir que es comprenga que l'objectiu no és trobar un resultat, sinó més aviat que hi ha dos camins per arribar-hi, és el repte. Es repetiran més vegades situacions semblants, fins que es puga considerar un fet general.

Introduirem la denominació de propietat commutativa per referir-nos a aquest fet i treballarem el seu enunciat «l'ordre dels sumands no altera la suma», o el que és el mateix, l'operació de l'addició permet obtenir el mateix resultat independentment de l'ordre de colllocació dels sumands. En llenguatge matemàtic:

$\forall a, b \in N: a+b=b+a$.

Es pot completar l'E-A d'aquesta propietat realitzat amb situacions reals treballant-la específicament amb materials didàctics. Els reglets Cuisenaire poden ser interessants per indicar que s'aconsegueix la mateixa longitud final col-locant en diferent ordre els reglets que representen els sumands.

Al llarg del 2n i 3r cicle, es treballaran activitats interessants per tal de reconèixer $\mathrm{i}$ aplicar aquesta propietat. Per reconèixer-la es proposarà una llista on hi haja parelles de problemes amb el mateix resultat, però amb dos sumands iguals en ordre d'addició diferent. Es buscarien les solucions de tots els problemes, i per concloure es treballaria la propietat, fent-los conscients que no calia resoldre el segon de cada parella, perquè aquesta operació ja estava feta.

Per comprovar si saben aplicar la propietat, es plantejarà una llista semblant a l'anterior on hauran de reconèixer les parelles de problemes amb les mateixes dades ordenades de manera diferent i decidir no resoldre el segon de cada parella, perquè ja en saben la solució.

Completant el treball anterior podem proposar-los dues addicions i que inventen enunciats o situacions reals on les solucions siguen les maneres indicades d'agrupar els dos nombres; darrerament els alumnes inventaran situacions problemàtiques per tal d'usar la propietat commutativa de l'addició sense cap indicació de quines addicions han d'usar.

En el 2n cicle completarem les propietats de l'addició treballant també la propietat associativa. Cal tenir en compte que aquesta requereix dos moments cognitius seqüenciats. Hi haurà una situació que obligarà a sumar dos nombres, i posteriorment se n'hi afegirà un tercer. En una segona situació, a la quantitat que abans ocupava el primer lloc, caldrà afegir-li el resultat de sumar les dues darreres quantitats.

Treballarem a partir de dues situacions problemàtiques, per exemple:

A l'aula hi ha dues caixes amb pilotes de colors. A la primera caixa hi ha 5 pilotes blanques $i 6$ de negres, quantes n'hi ha? A la segona n'hi ha 7 de verdes. Es volen reunir totes les pilotes a la primera caixa. Quantes n'hi ha en total?

A l'aula hi ha dues caixes amb pilotes de colors. A la primera caixa hi ha 5 pilotes blanques. A la segona hi ha 6 pilotes negres $i 7$ de verdes, quantes $n$ 'hi ha a la segona? Es volen reunir totes les pilotes a la primera caixa. Quantes n'hi ha en total? 
Afavorirem que l'ordre respectiu de les operacions i dels sumands siga el següent:

- Per a la 1a situació: $\quad 5+6=11 \quad 11+7=18$

- Per a la 2a situació: $\quad 6+7=13 \quad 5+13=18$

En el 2 n moment cognitiu i en tots els exemples que treballem cal arribar a simbolitzar les dues addicions de cada situació en una sola expressió:

- Per a la la situació: $\quad(5+6)+7=18$

- Per a la 2a situació: $\quad 5+(6+7)=18$

En aquest moment s'introduirà per primera vegada l'ús del parèntesi, que els servirà per indicar la seqüència de realització de les operacions.

A continuació expressaran la igualtat de resultats de la manera següent $(5+6)+7=$ $=18=5+(6+7)$, i finalment $(5+6)+7=5+(6+7)$. La reflexió anirà pel mateix camí que en la propietat anterior: no és tan important arribar al 18, sinó descobrir que la manera d'associar els sumands no altera el resultat. Haurem d'insistir en el fet que associar significa «agrupar seqüencialment».

Introduirem la denominació de propietat associativa per referir-nos a aquest fet $\mathrm{i}$ treballarem el seu enunciat: «La manera d'agrupar tres o més sumands no altera la suma». En llenguatge matemàtic:

$$
\forall a, b, c \in N:(a+b)+c=a+(b+c) .
$$

L'esquema de treball de la propietat associativa a l'aula de Primària és semblant al de la commutativa $\mathrm{i}$ per tant, l'alumnat també haurà de reconèixer $\mathrm{i}$ aplicar aquesta propietat. Per reconèixer-la es proposarà una llista on hi haja parelles de problemes amb igual resultat, però no amb la mateixa seqüenciació d'addicions. Es buscarien les solucions dels problemes i es treballaria la propietat, fent-los conscients que no calia resoldre el segon de cada parella, perquè aquestes operacions ja estaven fetes.

Per comprovar si saben aplicar la propietat, es plantejarà una llista semblant a l'anterior on hauran de reconèixer les parelles de problemes amb les mateixes dades agrupades de manera diferent i decidir no resoldre el segon de cada parella, perquè ja en saben la solució.

Completant el treball anterior podem proposar-los tres dades i que inventen dos enunciats o situacions reals on les solucions s'obtinguen agrupant de manera diferent aquestes dades com a sumands; darrerament els alumnes inventaran situacions problemàtiques per tal d'usar la propietat associativa de l'addició sense cap indicació de quines dades han d'usar. 
A.6. Descobrir l'algorisme de l'addició «sense portar-ne» $i$ utilitzar-lo per realitzar addicions «sense portar-ne» amb els sumands disposats verticalment $i$ horitzontalment

En la 3 a fase d'E-A de l'addició, i quan es presente a l'aula una situació en la qual siga necessari sumar amb els sumands de més d'una xifra, serà el moment d'introduir l'algorisme d'aquesta operació (no es necessita per tal de sumar dos nombres d'una xifra).

A continuació es proposa la primera part d'una seqüència didàctica ordenada per nivells de dificultat segons la qual s'hauria d'introduir l'algorisme de l'operació en el 1r cicle d'Educació Primària.

Començarem per l'algorisme de l'addició «sense portar-ne» (el resultat no passarà de 9 en qualsevol dels ordres d'unitats) que pot recórrer els trams següents:

1. Addició de dos nombres de dues xifres, per exemple: $12+24$.

2. D'un de dues xifres amb un altre d'una: $13+5$.

3. De dos nombres de tres xifres: $325+124$.

4. D'un de tres xifres amb un altre d'una o dues xifres: $325+4$ o $325+24$.

Treballarem la construcció d'aquest algorisme, per a comprendre'l i posteriorment automatitzar-lo, amb l'ajuda dels materials didàctics que ja coneixen (com són els BM i els àbacs) i la transcripció escrita de les accions que fan.

Suposem que es presenta a classe una situació problemàtica com la següent: «Ens trobem a la classe de $1 \mathrm{r}$ de Primària $\mathrm{i}$ en som 24. A la vesprada vindran $12 \mathrm{com}-$ panys de $2 \mathrm{n}$ curs $\mathrm{i}$ volem saber quantes cadires caldrà preparar per a tots»».

Es comentarà amb ells i elles com trobar la resposta al problema i arribarem a la conclusió que cal resoldre l'addició de 12 i 24, però no la saben calcular numèricament encara perquè els seus sumands són de dues xifres i ja no es troben a la taula de l'addició.

Després que diferents membres de l'alumnat presenten les seues propostes de resolució de l'operació i en la recerca de la manera comuna de fer-ho, introduirem l'algorisme estàndard corresponent.

Fent ús dels materials didàctics, al cas dels BM, per al 12 tindran un reglet i dos cubs i per al 24, dos reglets i quatre cubs. Si utilitzen dos àbacs verticals, en el primer representaran un sumand que serà el 12 i en el segon l'altre sumand, el 24. Es representa en la figura 43 aquesta ajuda, per exemple amb els àbacs. 


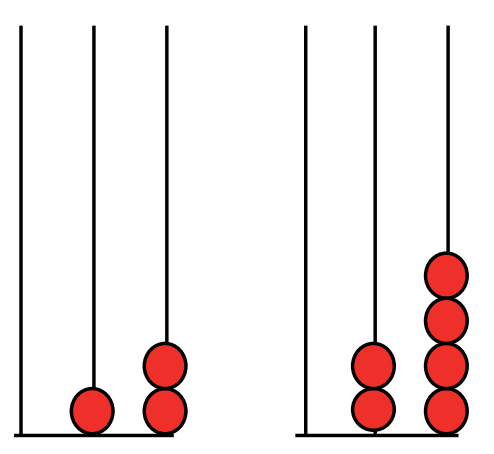

Figura 43. Representació de 12 i 24 amb àbacs

Abans de continuar manipulant els materials es comenta amb l'alumnat la necessitat d'expressar per escrit el que ocorre numèricament per tenir la memòria del procés que s'està portant i del resultat final. Per tal d'indicar les desenes i les unitats a l'hora de simbolitzar l'operació, podem utilitzar, si escau, les expressions amb unitats separades:

$$
\begin{array}{r}
1[10] 2 \\
+2[10] 4 \\
\hline ? ?
\end{array}
$$

Els preguntem què haurien de fer per tal d'obtenir el resultat final. Amb el BM barregen les peces agrupant d'una banda els cubs i de l'altra els reglets, i ja poden donar el resultat de l'operació: tres reglets i sis cubs; per tant, 36. El procés ha estat reorganitzar el material, verbalitzant en tot moment el que fan.

Als àbacs agrupen les boles per varetes en un dels dos, començant per les unitats. En finalitzar la tasca, troben 6 boles a la vareta de les unitats i 3 a la de les desenes, com es mostra a la figura 44. Per tant, el resultat és el nombre 36.
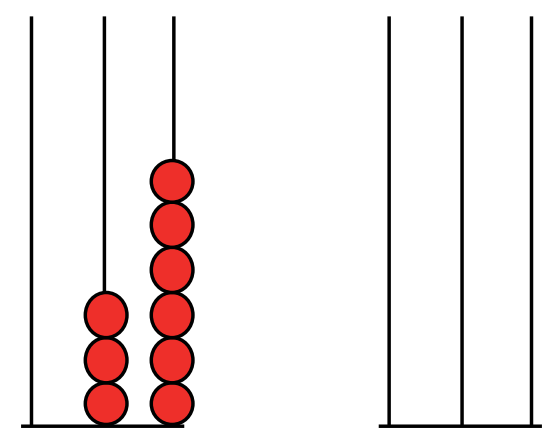

Figura 44. Representació amb àbacs del resultat de $12+24$

També podria utilitzar-se només un àbac, representant-hi el 12 i afegint el 24 a sobre d'aquesta representació.

De manera simultània a la manipulació amb els materials i la corresponent verbalització, treballarem la representació simbòlica amb les xifres: 


$$
\begin{array}{r}
1[10] 2 \\
+2[10] 4 \\
\hline \underbrace{3[10] 6}_{36}
\end{array} .
$$

Quan l'alumnat deixe de necessitar les unitats separades per entendre l'operació,

s'escriurà l'addició en l'expressió estàndard: $\frac{+24}{36}$.

La comprensió clara de les xifres que representen cada tipus d'unitats farà que la col·locació dels sumands en columna siga correcta, sense necessitar les expressions amb unitats separades. No s'hauria de passar a la disposició horitzontal (12+ $24=36$ ) fins que no estiga clara la representació vertical.

Per tornar al context del treball, respondrem a la pregunta de la situació problemàtica de partida: «Ens trobem a la classe de 1r de Primària i en som 24. A la vesprada vindran 12 companys de $2 \mathrm{n}$ curs i haurem de preparar 36 cadires per a tots».

S'han de fer més exemples d'addició reflexionant amb l'alumnat sobre la relació de les xifres dels sumands i les de la suma, ajudant-los a què mitjançant les situacions problemàtiques treballades arriben a la conclusió: «la xifra de les unitats del resultat és l'addició de les xifres de les unitats dels sumands i la xifra de les desenes del resultat és l'addició de les xifres de les desenes dels sumands». D'aquesta manera l'alumnat observa que s'ha transformat una addició de nombres de dues xifres en dues addicions de nombres d'una xifra, que ja sabien resoldre. I així descobreixen com funciona l'algorisme estàndard de l'addició sense portar-ne.

Numèricament se seguirà un procediment semblant per sumar sense portar-ne en els diferents trams de la seqüència didàctica proposada.

En 1r cicle de Primària ha de quedar assolit aquest algorisme, i així no hi haurà problemes amb l'addició sense portar-ne quan treballem amb nombres més grans en cursos posteriors, tant si l'operació es realitza en disposició vertical com horitzontal.

L'objectiu final serà arribar a usar aquest algorisme de l'addició amb l'expressió estàndard dels sumands com la manera natural de resoldre les addicions associades a la resolució de situacions problemàtiques.

\section{A.7. Descobrir l'algorisme de l'addició "portant-ne» $i$ utilitzar-ho per realitzar addicions "portant-ne» amb els sumands disposats verticalment $i$ horitzontal}

Una vegada està assolida l'addició sense portar-ne, i encara en 1r de Primària, és el moment per superar la barrera que els separa del repte següent: resoldre el problema que suposa l'addició de nombres, quan en algun ordre d'unitats la suma 
de xifres supera el nou, la qual cosa vol dir que s'està fent una addició portant-ne. Proposem ara la segona part de la seqüència didàctica ordenada per nivells de dificultat segons la qual s'hauria d'introduir l'algorisme de l'operació en el 1r cicle d'Educació Primària i que es refereix a l'addició portant-ne:

1. Addició portant-ne en les unitats, per exemple: $15+28,18+5,425+439$, $325+28 \ldots$

2. En les desenes únicament: $425+491,345+82 \ldots$

3. En les unitats i desenes: $137+285,176+69 \ldots$

Continuem treballant la construcció d'aquest algorisme, per comprendre'l i posteriorment automatitzar-lo, amb l'ajuda dels materials didàctics i la transcripció escrita de les accions que fan.

Suposem que es presenta a classe una situació problemàtica com la següent: «Per organitzar el porrat per les festes de la Magdalena l'alumnat de les dues aules de $1 \mathrm{r}$ de Primària necessita $15 €$ per a refrescos, aigua... i $28 €$ per comprar coques, cacaus... Quants diners han d'arreplegar en total?».

Es comentarà amb ells i elles com trobar la resposta al problema i arribarem a la conclusió que cal resoldre l'addició de 15 i 28, però no la saben calcular numèricament encara perquè hi ha una de les columnes (ordre d'unitats) la suma de la qual és major que 9 .

Després que diferents membres de l'alumnat presenten les seues propostes de resolució de l'operació i en la recerca de la manera comuna de fer-ho, introduirem l'algorisme estàndard corresponent.

Fent ús dels materials didàctics, al cas dels BM, per al 15 tindran un reglet i cinc cubs i per al 28, dos reglets i vuit cubs. Si utilitzen dos àbacs verticals, en el primer representaran un sumand que serà el 15 i en el segon l'altre sumand, el 28. Es representa en la figura 45 aquesta ajuda, per exemple amb els BM.
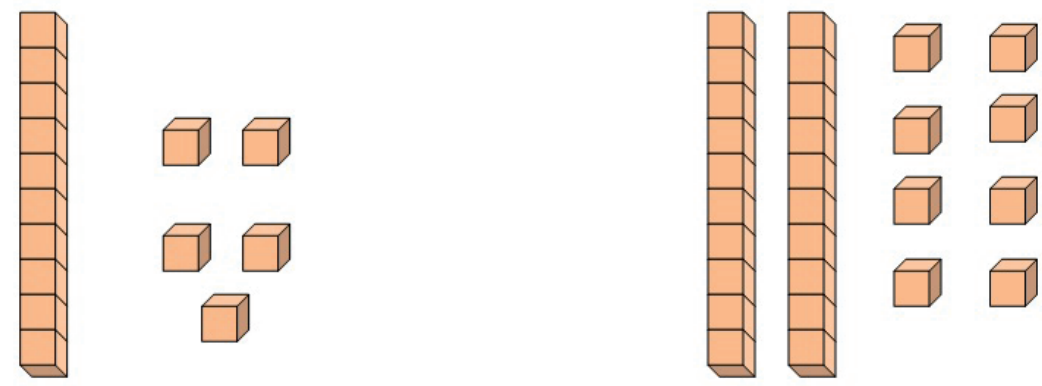

Figura 45. Representació de 15 i 28 amb вM

Abans de continuar la manipulació dels materials i amb la finalitat de tenir un registre del procés que es desenvoluparà i del resultat final que obtinguem, simbolitzarem l'operació utilitzant les expressions amb unitats separades, si escau. 


$$
\begin{array}{r}
1[10] 5 \\
+2[10] 8 \\
\hline ? ?
\end{array}
$$

Els preguntem què haurien de fer per obtenir el resultat final. Amb els BM agrupen d'una banda els cubs, n'obtenen tretze, i de l'altra els reglets, ajuntant-ne tres, com es mostra a la figura 46.
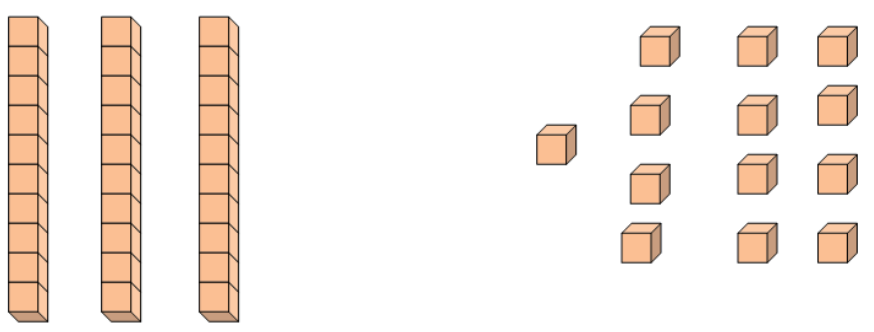

Figura 46. Representació de l'agrupació de 15 i 28 amb BM

Si treballem amb els àbacs comencen per les unitats, afegint les 5 boletes del primer en el segon, amb la qual cosa a la vareta de les unitats hi ha ara 13 boles. Continuen a la vareta de les desenes, afigen una bola on n'hi havia dues, i queden 3 boles en el segon àbac.

De manera simultània al treball amb qualsevol dels dos materials, verbalitzen el que ha passat $\mathrm{i}$ ho representen numèricament:

$$
\begin{array}{r}
1[10] 5 \\
+2[10] 8 \\
\hline 3[10] 13
\end{array}
$$

S'adonen que la representació numèrica del resultat obtinguda no compleix les regles de l'SND. Verbalitzen aquesta situació i la seua solució. Transformen 10 unitats en 1 desena i l'afigen a l'addició de les desenes dels sumands, «n'han portat una». Amb els materials implica substituir els cubs per reglets en el cas dels BM (figura 47) o canviar boles i situar-les a les varetes adients, en el cas dels àbacs.

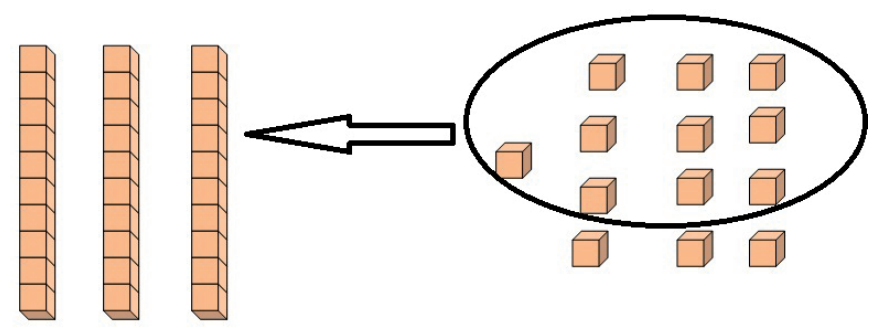

Figura 47. Transformació de 10 cubs en un reglet 
Així, arriben a tenir 4 peces representant les desenes, i 3 les unitats, de manera que la suma total és 43. Es representa en la figura 48 aquest exemple amb els BM.

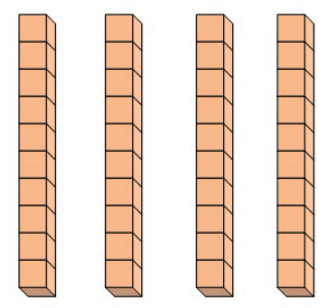

Figura 48. Representació amb BM del resultat de $15+28$

A continuació mostrem de manera detallada els canvis numèrics que acompanyen la manipulació dels materials:

$$
\begin{aligned}
& \text { 1[10] } 5 \\
& +2[10] 8 . \\
& 3[10] \underbrace{13} \\
& \underbrace{3[10] 3}_{4[10] 3}
\end{aligned}
$$

Amb l'alumnat, simultàniament a la manipulació amb els materials i la corresponent verbalització, modificarem la representació simbòlica del resultat, i arribarem a l'expressió:

$$
\begin{array}{r}
1[10] 5 \\
+2[10] 8 \\
\hline 4[10] 3
\end{array}
$$

on la desena que resulta de la suma de les unitats i que s'afig a les desenes («n'hem portat una»), es pot recordar de manera gràfica amb un 1 més menut a sobre de la columna de les desenes.

Quan l'alumnat deixe de necessitar les unitats separades per entendre l'operació, s'escriurà l'addició en l'expressió estàndard:

$$
\begin{array}{r}
1 \\
15 \\
+28 \\
\hline 43
\end{array}
$$

Novament, la comprensió clara de les xifres que representen cada tipus d'unitats farà que la col·locació dels sumands en columna, i del resultat, la suma, siguen correctes, sense necessitar les expressions amb unitats separades. 
No s'hauria de passar a la disposició horitzontal $(15+28=43)$ fins que no estiga clara la representació vertical.

Per tornar a contextualitzar el treball de l'operació, respondrem a la pregunta de la situació problemàtica de partida: «Per organitzar el porrat per les festes de la Magdalena l'alumnat de les dues aules de $1 \mathrm{r}$ de Primària necessita $15 €$ per a refrescos, aigua..., i $28 €$ per comprar coques, cacaus..., per la qual cosa han d'arreplegar un total de 43 euros».

Es faran més exemples d'addicions reflexionant amb l'alumnat sobre la relació de les xifres dels sumands i les de la suma, ajudant-los que mitjançant les situacions problemàtiques treballades arriben a la conclusió: «se suma de dreta a esquerra i, com que en l'addició de les unitats dels sumands obtenim una desena, haurem d'afegir-la («en portem una desena») a l'addició de les desenes dels sumands».

A partir d'aquest moment, i possiblement sense necessitat d'utilitzar els materials, en les següents addicions aplicaran el que acaben d'aprendre i just a continuació de sumar les unitats, transformaran les 10 unitats en 1 desena («en portem una») que afegiran a la posterior addició de les desenes dels sumands. La representació simbòlica (amb unitats separades, si escau) seria:

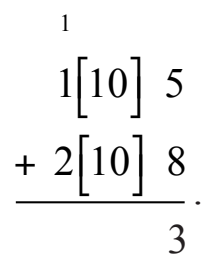

Els passos següents d'aquest treball es desenvoluparan de manera semblant al que s'ha explicat anteriorment (finalitzar l'operació, recontextualitzar...).

En la reflexió amb l'alumnat sobre la relació de les xifres dels sumands i les de la suma, els ajudarem a què mitjançant els exemples treballats arriben a la conclusió semblant a: «se suma de dreta a esquerra, la xifra de les unitats de la suma és la xifra de les unitats del resultat de l'addició de les unitats dels sumands i la xifra de les desenes de la suma és el resultat de l'addició de les desenes dels sumands més la desena que portem». Han completat el descobriment de l'algorisme estàndard de l'addició portant-ne en unitats.

L'objectiu final serà arribar a usar l'algorisme estàndard de l'addició amb l'expressió numèrica dels sumands com la manera natural de resoldre les addicions en les quals la desena que es porta («en portem una») es recordarà de manera mental.

En 2n curs de Primària, se seguirà un procediment semblant per sumar portant-ne en les desenes amb nombres de tres xifres i intentarem que per sumar portant-ne en unitats i en desenes no siga necessària la utilització dels materials.

A continuació es mostra un exemple de representació numèrica d'una d'aquestes addicions, $554+368$, que es realitzarà amb unitats separades, si escau: 


$$
\begin{aligned}
& \stackrel{1}{5}[100] \quad 5[10] \quad 4 \\
& \begin{array}{r}
+3[100] 6[10] 8 \\
\hline 9[100] 2[10] 2
\end{array}
\end{aligned}
$$

o directament amb l'expressió estàndard de l'algorisme: +368 .

En 1r cicle de Primària ha de quedar assolit aquest algorisme, i així no hi haurà problemes amb l'addició portant-ne quan treballen amb nombres més grans en cursos posteriors i en generalitzen l'ús, tant si l'operació es realitza en disposició vertical com horitzontal.

\section{A.8. Desenvolupar l'agilitat mental en el càlcul de l'addició}

Utilitzarem l'addició per exercitar el càlcul mental de manera espontània, en veu alta, dins d'un joc, en diferents situacions... i sempre en un nivell de dificultat inferior del que s'estiga treballant a classe en l'àmbit simbòlic. Cal treballar el fet de sumar sense haver d'usar llapis i paper. De fet, és la manera de calcular més relacionada amb la vida real, ja que en situacions extraescolars, al carrer, a casa... és on més addicions faran.

En el 1r cicle de Primària, es treballaran els resultats de la taula de l'addició, les addicions senzilles de nombres de dues xifres, començant amb desenes completes perquè els resulte més fàcil, $i$, com que a classe s'ha treballat la descomposició polinòmica, utilitzarem aquesta eina per al càlcul mental. Així, per exemple, si se'ls demana sumar $22+5$, mentalment es podrien ajudar pensant « 22 és $20+2 \rightarrow 5+$ $2=7$; aleshores, $20+7=27 \gg$.

Cal estar atents també a totes les estratègies emergents que apareixen en els xiquets i xiquetes, i a la construcció de la seua pròpia manera de calcular mentalment, així com a les ajudes que ens poden oferir les propietats commutativa i associativa de l'addició. Per exemple, si un xiquet o xiqueta ha de sumar $15+9$, és possible que li resulte més fàcil sumar $15+10 \mathrm{i}$, al resultat, llevar-ne 1 ; o assumir que el $9=5+4$ i per tant els és més fàcil sumar $15+5 \mathrm{i}$ al resultat sumar-ne 4 . Aquestes maneres «personals» de sumar comporten conèixer la composició dels nombres de manera additiva, la utilitat de les propietats commutativa i associativa de l'addició i que arriben a veure una determinada quantitat en funció d'algunes descomposicions additives, més útils, que tinga. Per exemple el $100=25+25+25+25$, aquestes «quatre vegades 25 » els fa arribar ràpidament als $25,50,75,100$. $\mathrm{O}$ el $60=15+$ $15+15+15$ i per tant arribar ràpidament $\mathrm{a} 15,30,45,60$; etc.

Hi ha també estratègies «reglades» que poden utilitzar i que haurem de treballar a classe per si algú o alguna les poden fer servir: la graella del 100 o la línia numèrica buida (Barba, 2004). 
La primera s'encarrega de construir una taula de 10 per 10, on de manera horitzontal es van col·locant els primers 100 naturals no nuls (vegeu figura 49), de forma que per haver de sumar $15+23$, per exemple, ens situaríem en el 15 i hauríem de desplaçar-nos mentalment a sobre de la taula. Si elegim primer sumar les dues desenes, el moviment que haurien de fer seria de dues posicions de manera vertical, s'arribaria així al 35. En aquest punt i de manera horitzontal cal moure's tres posicions cap a la dreta, arribaríem al 38. Aquest recorregut seria igual de vàlid si primer ens desplacem horitzontalment i després verticalment.

\begin{tabular}{|c|c|c|c|c|c|c|c|c|c|}
\hline 1 & 2 & 3 & 4 & 5 & 6 & 7 & 8 & 9 & 10 \\
\hline 11 & 12 & 13 & 14 & 15 & 16 & 17 & 18 & 19 & 20 \\
\hline 21 & 22 & 23 & 24 & 25 & 26 & 27 & 28 & 29 & 30 \\
\hline 31 & 32 & 33 & 34 & 35 & 36 & 37 & 38 & 39 & 40 \\
\hline 41 & 42 & 43 & 44 & 45 & 46 & 47 & 48 & 49 & 50 \\
\hline 51 & 52 & 53 & 54 & 55 & 56 & 57 & 58 & 59 & 60 \\
\hline 61 & 62 & 63 & 64 & 65 & 66 & 67 & 68 & 69 & 70 \\
\hline 71 & 72 & 73 & 74 & 75 & 76 & 77 & 78 & 79 & 80 \\
\hline 81 & 82 & 83 & 84 & 85 & 86 & 87 & 88 & 89 & 90 \\
\hline 91 & 92 & 93 & 94 & 95 & 96 & 97 & 98 & 99 & 100 \\
\hline
\end{tabular}

Figura 49. Taula del 100

L'objectiu de treballar amb aquesta tècnica és que l'alumnat arribe a formar-se una imatge mental de la taula que l'ajude a fer el recorregut mental de l'addició sense haver-la de tenir present.

Aquesta tècnica té limitacions. Per exemple, en l'addició $27+15$, en el moment de desplaçar-nos horitzontalment en sumar les unitats, eixiríem de la taula. Caldria fer un esforç afegit per imaginar que cal tornar a entrar pel principi de la fila següent. I és obvi que per quantitats superiors a 100, o bé ens imaginem la taula només per les desenes i unitats o bé cal recrear una taula més gran.

La línia numèrica buida és una estratègia semblant a l'anterior però intenta solucionar les esmentades limitacions. Es tracta de representar a sobre d'una línia horitzontal, els salts mentals que el xiquet o xiqueta fa quan suma. Replega les esmentades estratègies emergents i per tant, hi ha diverses possibilitats per arribar al resultat. Per exemple, per haver de sumar 27 més 15 ens situem en el 27 i a modus de salts (de la quantitat d'unitats que cadascú vulga, és lliure) i que configuren el 15 , ens acostem al resultat final.

L'objectiu, novament, és que contribuïsca al càlcul mental, utilitzant la línia de manera mental fent cada vegada salts més adequats a les quantitats que cal sumar. 
A mesura que es va dominant aquest càlcul mental i es treballen les altres operacions, es pot combinar gradualment l'addició amb elles per tal de fer un treball conjunt.

\section{A.9. Resoldre i inventar situacions problemàtiques relacionades amb l'addició}

És en situacions reals on cobra especial sentit el treball fet en l'addició, perquè realment és la realitat la que origina interrogants la resposta dels quals passarà per saber, en aquest cas, resoldre addicions.

Malgrat que la resolució i la invenció de problemes apareix com la quarta fase per treballar les operacions, ens hi trobem des del principi, perquè presentem les operacions de manera contextualitzada, a partir de situacions reals que han de resoldre's i, per tant, que poden estar relacionades amb qualsevol bloc de continguts matemàtics.

Treballarem la resolució de problemes prenent com a orientació les quatre fases de Polya (comprendre el problema, elaborar un pla, executar el pla i examinar la solució obtinguda) i reflexionant amb l'alumnat sobre la importància, desenvolupament i utilitat de cadascuna.

Quan es troben resolent els problemes, hem d'aprofitar els errors que puguen sorgir per reflexionar-hi amb els nens i les nenes, com a conseqüència, potenciar noves situacions d'aprenentatge a partir de la reflexió. És molt important diferenciar entre els errors de càlcul $\mathrm{i}$ els errors de raonament atès que exigeixen mètodes diferents pel seu tractament.

Els hem d'acostumar a estimar el resultat de la situació problemàtica amb la finalitat de practicar el càlcul mental i que es facen una idea del nombre que han d'obtenir.

Iniciarem el treball en 1r de Primària, amb problemes que necessiten ser resolts amb una addició, seguits d'altres que en necessiten dues. Aquests problemes seran de nombres de fins a dues xifres, per passar a $2 \mathrm{n}$ de Primària amb nombres de tres xifres.

També, i a dins d'aquest 1r cicle, es poden treballar problemes que necessiten la combinació d'una addició i una subtracció per ser resolts.

Insistint en les fases de Polya esmentades anteriorment i per possibilitar el correcte desenvolupament de la primera haurem de treballar problemes amb diferents tipus d'enunciats:

- En un primer moment, resoldran problemes amb enunciats clars, ordenats, complets, sense errors...

- En un segon moment, problemes amb enunciats confusos, incomplets, amb dades que falten, amb dades que sobren... 
L'alumnat ha de treballar també la invenció de problemes relacionats amb l'addició. El que es pretén és comprovar si són capaços de generar situacions que es resolguen amb l'operació estudiada. El treball d'inventar problemes serà posterior al de resoldre'ls. No els demanarem mai que inventen un problema d'un tipus que encara no s'haja resolt.

Cada vegada que els proposem la invenció d'un tipus nou de problemes seguirem els passos següents que es troben seqüenciats per nova dificultat, independentment del curs en què es trobem:

- Amb ajudes:

- Els donarem els nombres, les operacions i el context que intervenen en la situació («inventa un problema d'ànecs i conills, amb un 15 i un 38, que es resolga amb una addició», per exemple).

- Els donarem els nombres i les operacions, però no el context («inventa un problema amb un 15 i un 38, que es resolga amb una addició», per exemple).

- Sense ajudes: els donarem sols les operacions que han d'aparèixer en la situació problemàtica («inventa un problema que es resolga amb una addició», per exemple).

En un moment posterior al d'inventar les situacions problemàtiques, les intercanvien amb els companys perquè cap xiquet o xiqueta resolga la que ell mateix ha inventat, amb la finalitat de potenciar la seua capacitat tant de redactar com d'expressió matemàtica, que implicarà l'exigència de claredat $i$ de totalitat en dades $i$ incògnites.

En els cicles posteriors es continuaran les tasques de resolució i invenció de situacions problemàtiques relacionades amb l'addició, en les quals aquesta operació es combinarà amb les altres tres a mesura que vagen dominant-les.

\section{A.10. Realitzar exercicis pràctics d'addicions en el sistema de numeració sexagesimal}

Aquest tipus d'addicions es treballaran en el 3r cicle de Primària, aprofitant que poden trobar-se situacions problemàtiques més complexes relacionades amb la mesura del temps o de l'amplitud angular. Aquesta introducció a l'addició en el sistema sexagesimal es desenvoluparà de manera progressiva, fent operacions sense portar-ne i posteriorment portant-ne, en els segons, en els minuts, tots dos alhora...

L'addició sense portar-ne en el sistema sexagesimal es realitzarà sumant per separat cadascun dels ordres de les unitats, com es pot veure en el següent exemple: 


$$
\begin{array}{r}
25 \mathrm{~h} 15 \mathrm{~min} 19 \mathrm{~s} \\
+10 \mathrm{~h} 40 \mathrm{~min} 20 \mathrm{~s} \\
\hline 35 \mathrm{~h} 55 \mathrm{~min} 39 \mathrm{~s}
\end{array}
$$

Cal notar que en l'operació conviuen les xifres indo-aràbigues i els ordres de les unitats del sistema sexagesimal, i que resulta imprescindible tenir present aquest fet per a la comprensió de l'algorisme de l'addició en aquest sistema.

Cal incidir en ells i elles que el fet de portar-ne ocorre en aquest cas quan sobrepassem els 60 en algun dels dos primers ordres d'unitats i que es fan les transformacions dels resultats sense memoritzar els processos de «portar-ne una» per la poca freqüència amb la qual necessitem aquestes operacions i per evitar el treball mental amb nombres tan grans.

A continuació presentem un exemple d'addició en el sistema sexagesimal, portant-ne en els segons, en el qual representem de manera numèrica el procés de l'operació i els canvis necessaris per arribar al resultat final correcte:

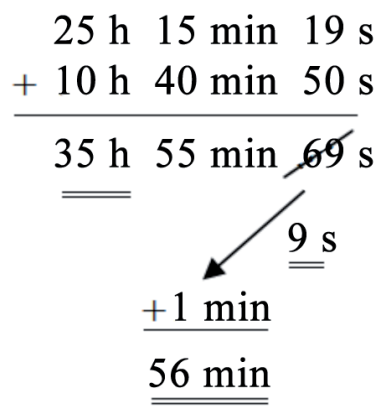

Anàlogament, es mostra ara un exemple d'addició en el sistema sexagesimal, portant-ne en els segons i en els minuts:

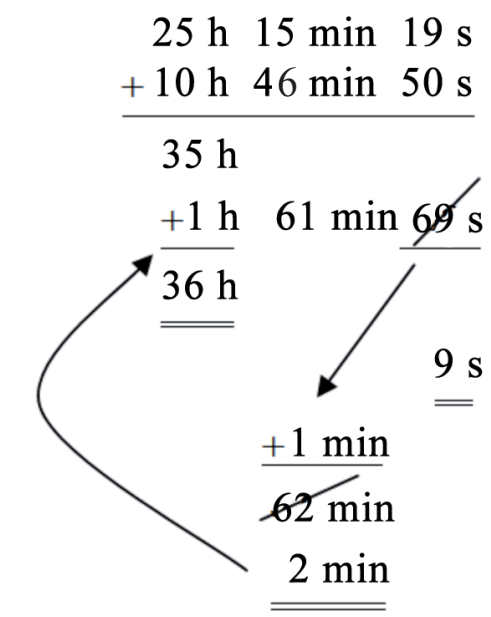

El procediment serà anàleg quan treballem amb quantitats referents a l'amplitud angular. 


\section{B. Subtracció}

La noció de subtracció de nombres naturals va lligada, de la mateixa manera que la de l'addició, al concepte de conjunt.

Atenent la seua definició, la subtracció és l'operació que ens permet calcular la resta o diferència entre dos nombres, entenent que aquesta resta és el cardinal del complementari d'un subconjunt, el cardinal del qual és el nombre menor, respecte d'un conjunt, el cardinal del qual és el nombre major.

Però, a diferència de l'addició que sols estava relacionada amb situacions «d'afegir i reunir», la subtracció s'associa amb altres tipus de situacions que li donen també altres significats.

Partirem d'activitats pràctiques i manipulatives, per tal de recrear situacions que ens permeten treballar-los tots i utilitzarem la subtracció com a eina per resoldre els tipus de situacions següents:

- De disminuir: «8 alumnes estan fent un dibuix, n'acaben 5, quants en queden dibuixant encara?». Aquest cas és una aplicació directa de la definició. Hi ha una situació final on s'ha trobat el complementari del subconjunt de xiquets que ja han acabat el dibuix. Es tracta de simbolitzar amb una subtracció el que ha passat.

- D’afegir per arribar a una nova quantitat: «Si una xiqueta necessita 9 peces per a muntar un joguet desmuntable i sols en té 3, quantes peces li falten?». Aquesta situació recorda l'addició, però en el fons és una acció contrària a sumar, perquè consisteix en el fet de completar una unió de dos conjunts en la qual se'n coneix un i el resultat de la unió. Per tant, la simbolització partirà d'una addició incompleta per arribar a una subtracció.

- De comparar cardinals: «Tinc 4 euros i tu 7, quants en tens més que jo?». L'acció real és comparar el cardinal de dos conjunts disjunts, però novament l'operació interna és la subtracció. Arribarem a la seua simbolització reflexionant sobre la idea que els xiquets tenen de l'operació adquirida en les situacions anteriors.

Mitjançant exemples aclaridors i utilitzant nombres menuts, anirem propiciant els tres tipus de situacions exposades abans per aconseguir una visió completa de l'operació.

Es pot observar clarament que el fonament matemàtic d'aquesta operació és sempre el que s'ha esmentat en la definició i que, en qualsevol dels tres tipus de situacions reals, estem trobant el complementari d'un subconjunt: de forma directa en el primer cas; a partir de la seua unió amb el subconjunt corresponent en el segon; a partir de la immersió mitjançant una correspondència biunívoca del conjunt amb menys elements en l'altre i de la seua identificació amb un subconjunt d'aquest, en el tercer cas. 


\section{B.1. Construir la idea de subtracció a partir del complementari d'un subconjunt}

d'un conjunt donat, $i$ expressar els cardinals respectius

En aquesta capacitat desenvolupem el treball corresponent a la primera de les fases d'E-A de la subtracció, que es realitza en el 1r curs de l'etapa.

Cal partir d'activitats pràctiques i manipulatives per recrear situacions que puguen identificar ràpidament. Les situacions que hem de presentar són aquelles en les quals, en l'estat final, hi ha una disminució de la quantitat d'elements respecte de l'estat inicial (prestar, perdre, gastar, menjar, trencar...).

Per exemple, si un xiquet o una xiqueta té 5 llapis de colors per pintar una caseta $\mathrm{i}$ en presta 2 a un company, li podem preguntar, quants en tens ara? Normalment el que farà és comptar els que li queden 1, 2, 3, i respondre: 3 colorins. Mentalment no ha pensat «5 menys 2 és igual a $3 »$, simplement ha comptat.

Els proposarem que expliquen verbalment el que ha passat amb els objectes insistint en la utilització dels nombres que han intervingut en la situació. Així, diran «tenia cinc colors i n'he prestat dos, aleshores queden tres colors». En posteriors repeticions de les accions, la verbalització anirà evolucionant passant per expressions com «en tenia cinc i n' he prestat dos, aleshores en queden tres» fins a arribar a «cinc menys dos són tres».

És convenient que l'alumnat acompanye la manipulació i la verbalització amb una representació gràfica (figura 50) del que ha ocorregut amb el material, en la qual a més, apareguen els nombres involucrats.

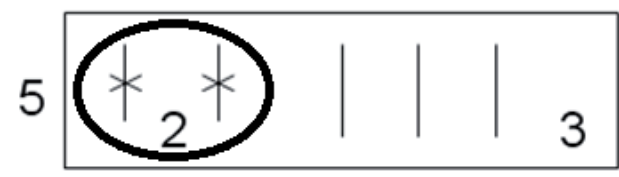

Figura 50. Representació de la manipulació de 5 menys 2

Aquesta tasca constituirà, igual que en l'addició, el primer pas per valorar la importància d'aprendre a resoldre aquestes situacions sols amb els nombres, sense que siga necessari tenir sempre a l'abast els objectes concrets que hi intervenen, i facilitar així l'accés a la fase simbòlica. S'introduirà la paraula subtracció associada a les relacions numèriques que apareixen a partir d'aquestes accions manipulatives.

El final de la fase serà demanar als xiquets i xiquetes que siguen ells $i$ elles qui troben o reconeguen situacions de la seua vida personal que estiguen relacionades amb l'operació (llibres, cromos...). 
B.2. Utilitzar els signes «-» $i$ «=» per simbolitzar subtraccions. Identificar els termes $i$ els signes de la subtracció

Continuant en el 1r curs, una vegada realitzades les accions anteriors i coneguda la paraula subtracció, és el moment de passar a la segona fase d'E-A de l'operació, $\mathrm{i}$ introduir els símbols «-» i «=»; aleshores, l'enunciat verbal «cinc menys dos són tres» es canvia per l'enunciat numèric « $5-2=3 »$, en un primer moment de manera 5

horitzontal, que canviarem posteriorment a la disposició vertical - 2 que facilitarà més endavant l'aprenentatge de l'algorisme. 3

A més a més, s'ha de conèixer la nomenclatura específica: el 5 i el 2, que són els termes de l'operació, s'anomenen minuend i subtrahend respectivament, i el 3, que és el resultat, s'anomena resta o diferència. El signe «-» es llegeix menys, i el signe «=», igual (que ja el coneixien de l'addició).

En el moment que s'hagen conegut els termes i signes de les restants operacions, haurem de comprovar que l'alumnat els identifica i diferencia correctament.

\section{B.3. Realitzar subtraccions de nombres a partir de la complementació de conjunts}

És important que després d'haver introduït l'expressió simbòlica de l'operació, aquesta no es desconnecte de les accions amb les quals es relaciona. Per això, també en el 1r curs i en moments posteriors al treball de la capacitat anterior, caldrà mostrar-los expressions numèriques de subtraccions que hauran de resoldre mitjançant accions de retirar una determinada quantitat d'objectes d'un conjunt $\mathrm{i}$ esbrinar quants en queden després de fer-ho.

Aquest és un treball invers al realitzat en les dues capacitats anteriors, en les quals l'alumnat avançava des de les accions amb els objectes fins les expressions simbòliques de les situacions.

Si els xiquets i xiquetes són capaços de trobar els resultats de les subtraccions propostes sense recórrer als objectes, poden resoldre-les d'aquesta manera, però haurem de reflexionar amb ells sobre el significat de l'operació i sobre la seua relació inequívoca amb situacions en què es retiren uns elements d'un conjunt de partida i s'obté com a resultat un nombre menor que el seu cardinal inicial.

\section{B.4. Associar la subtracció amb unions de conjunts disjunts en les quals falte un dels esmentats conjunts, $i$ expressar els cardinals respectius}

Després d'haver introduït les primeres situacions reals que necessiten la subtracció i encara dins de la primera de les fases d'E-A d'aquesta operació, que es realitza en el 1r curs de l'etapa, treballarem un nou tipus de situacions que també es resolen restant $i$ en les quals és necessari afegir elements a un conjunt inicial per formar un altre amb un cardinal major. 
Per exemple, si un xiquet o una xiqueta té 5 llapis de colors i en necessita 8 per pintar una caseta, la pregunta serà, «quants te'n falten»? Normalment, el que farà és agafar d'una safata els 3 que li falten, afegint-los als 5 inicials, mentre va comptant des de 5 fins a 8.

Els proposarem que expliquen verbalment què ha passat amb els llapis de colors insistint en la utilització dels nombres que han intervingut en la situació. Sorgiran expressions del tipus «tenia cinc colorins i he hagut d'agafar-ne tres més per tenir vuit», que anirem abreviant fins a arribar a «en tenia cinc i n'he agafat tres per tenir vuit».

De manera anàloga que en la capacitat B.1, és convenient que l'alumnat acompanye la manipulació i la verbalització amb una representació gràfica (figura 51) del que ha ocorregut amb el material, en la qual, a més, apareguen els nombres involucrats.

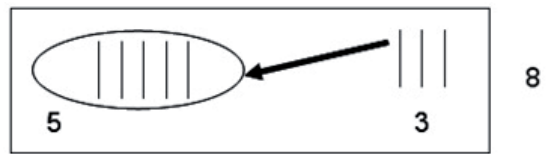

Figura 51. Representació de la manipulació de 5 fins a 8

Aquesta tasca constituirà de nou el primer pas per valorar la importància d'aprendre a resoldre aquestes situacions sols amb els nombres, sense que siga necessari tenir sempre a l'abast els objectes concrets que hi intervenen, i facilitar així l'accés a la fase simbòlica.

Si els preguntem com es podria escriure el que ha passat d'una manera més ràpida, sols amb els nombres, trobarem que l'operació que es relaciona amb accions d'afegir elements és l'addició. Sorgirà així una expressió del tipus $5+\ldots=8$, en la qual el nombre buscat és un dels sumands d'una addició incompleta.

B.5. Completar addicions en les quals falte un sumand $i$ simbolitzar aquestes addicions incompletes usant els signes «-» $i \ll=»$. Repassar els termes $i$ signes de la subtracció

Amb un treball semblant al de la capacitat B.3, proposarem a classe algunes addicions numèriques incompletes perquè l'alumnat les resolga: $3+\ldots=9$, per exemple.

Es pretén que relacionen les expressions matemàtiques de les addicions incompletes amb les situacions reals que les provoquen, és a dir, situacions d'afegir euros, bolígrafs, xiquets, entrepans... als que tenen al principi, per a aconseguir una quantitat major. De nou és un treball invers al realitzat en la capacitat anterior en la qual s'avançava dels objectes fins als nombres. 
Davant aquesta forma «estranya» d'expressar les operacions que estem fent, els podem preguntar quina operació dóna el resultat que obtenim en cada cas partint de les dades inicials, amb la intenció d'arribar a transformar les addicions incompletes en subtraccions, el minuend de les quals és el resultat conegut de l'addició i el subtrahend és el sumand també conegut. Així la nostra addició anterior es transformaria en: $9-3=$

Una vegada relacionada la subtracció amb aquestes situacions, repassarem els termes i els signes corresponents, revisarem els seus noms i significats, i reforçarem a la vegada l'associació del minuend amb el nombre major i del subtrahend amb el menor en qualsevol dels casos que es presente.

A partir d'aquest moment resoldrem les situacions «d'afegir per arribar a una nova quantitat» usant la subtracció.

B.6. Associar la subtracció amb la comparació dels cardinals de dos conjunts. Utilitzar els signes «-» $i$ «=» per expressar numèricament la diferència entre els esmentats cardinals. Repassar els termes $i$ signes de la subtracció

En aquesta capacitat continuem encara dins de la primera de les fases d'E-A d'aquesta operació, que es realitza en el 1r curs de l'etapa, i treballarem un nou tipus de situacions que també es resolen restant $i$ en les quals és necessari comparar els cardinals de dos conjunts disjunts per esbrinar la diferència entre ells.

Per exemple, estem a la biblioteca de l'aula i Mireia ha agafat 6 contes. Si Àngel en té 4 , els podem preguntar, quants en té Mireia més que Àngel?

Per respondre la pregunta s'estableix una correspondència biunívoca entre els conjunts, que associa tots els elements d'un dels dos en alguns de l'altre i es compten els que queden sense associar, en aquest cas 2 .

Anàlogament als casos anteriors els proposarem que ens expliquen verbalment què han pensat per respondre i que facen un dibuix que ho represente (figura 52), en el qual apareguen els nombres involucrats en la situació.

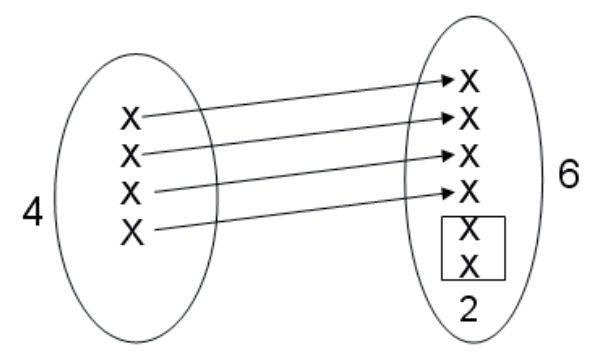

Figura 52. Representació de la comparació entre els cardinals 4 i 6

Una vegada trobat el 2 com a solució, els preguntarem si és necessari sempre fer les correspondències per resoldre aquest tipus de situacions o si es poden esbrinar 
els resultats directament amb els nombres. Es tracta de saber si alguna de les operacions que coneixen dóna com a resultat el nombre obtingut partint de les dades inicials en cada cas. Després que els xiquets responguen referint-se a la subtracció, el resultat de la nostra comparació es simbolitzaria $6-4=2$.

Associarem aleshores la subtracció amb les situacions de comparació de cardinals treballades i, a partir d'ara, sempre utilitzarem l'operació per resoldre aquests tercer tipus de situacions.

Representarem les subtraccions de la forma ja coneguda per les capacitats anteriors i repassarem la identificació del minuend amb el cardinal major i del subtrahend amb el menor, i recordarem també els signes de l'operació.

\section{B.7. Conèixer els resultats de les subtraccions bàsiques (les que es dedueixen de la taula de l'addició)}

Simultàniament al treball de manipulació d'objectes quotidians, els quals hauran retirat, afegit, comparat quantitativament, etc., i per tal de recollir els resultats de les subtraccions realitzades, poden emplenar una graella en la qual es recullen les subtraccions bàsiques, amb l'objectiu d'ajudar-los en els càlculs de les subtraccions posteriors.

En 1r curs de Primària, es representaran sols resultats de subtraccions sense portar-ne i s'obtindrà la taula següent (es consideren com a minuends els nombres situats en l'eix horitzontal i com a subtrahends els col-locats en el vertical):

\begin{tabular}{|c|c|c|c|c|c|c|c|c|c|}
\hline- & 1 & 2 & 3 & 4 & 5 & 6 & 7 & 8 & 9 \\
\hline 1 & 0 & 1 & 2 & 3 & 4 & 5 & 6 & 7 & 8 \\
\hline 2 & & 0 & 1 & 2 & 3 & 4 & 5 & 6 & 7 \\
\hline 3 & & & 0 & 1 & 2 & 3 & 4 & 5 & 6 \\
\hline 4 & & & & 0 & 1 & 2 & 3 & 4 & 5 \\
\hline 5 & & & & & 0 & 1 & 2 & 3 & 4 \\
\hline 6 & & & & & & 0 & 1 & 2 & 3 \\
\hline 7 & & & & & & & 0 & 1 & 2 \\
\hline 8 & & & & & & & & 0 & 1 \\
\hline 9 & & & & & & & & & 0 \\
\hline
\end{tabular}

Cal notar que no poden emplenar-se totes les caselles. Les de la part inferior esquerra de la taula es queden buides perquè el nombre seria negatiu i encara no coneixen nombres d'aquest tipus.

En $2 n$ curs es comença a treballar la subtracció portant-ne. És el moment d'ampliar la taula anterior afegint en la part dels minuends els nombres que apareixen com 
a resultats a la taula de l'addició i mantenint els mateixos subtrahends. D'aquesta manera s'incorporen a la taula els resultats de les subtraccions immediates, necessàries per treballar els algorismes portant-ne que desenvoluparem a continuació.

Per tant, la taula s'estendrà cap a la dreta amb la incorporació de les caselles següents:

\begin{tabular}{|c|c|c|c|c|c|c|c|c|c|}
\hline- & 10 & 11 & 12 & 13 & 14 & 15 & 16 & 17 & 18 \\
\hline 1 & 9 & & & & & & & & \\
\hline 2 & 8 & 9 & & & & & & & \\
\hline 3 & 7 & 8 & 9 & & & & & & \\
\hline 4 & 6 & 7 & 8 & 9 & & & & & \\
\hline 5 & 5 & 6 & 7 & 8 & 9 & & & & \\
\hline 6 & 4 & 5 & 6 & 7 & 8 & 9 & & & \\
\hline 7 & 3 & 4 & 5 & 6 & 7 & 8 & 9 & & \\
\hline 8 & 2 & 3 & 4 & 5 & 6 & 7 & 8 & 9 & \\
\hline 9 & 1 & 2 & 3 & 4 & 5 & 6 & 7 & 8 & 9 \\
\hline
\end{tabular}

També ara observem que no s'emplenen totes les caselles. Les de la part superior dreta de la taula es queden buides perquè és innecessari recordar aquests resultats de manera automàtica ja que no corresponen a subtraccions immediates.

\section{B.8. Descobrir l'algorisme de la subtracció sense portar-ne i utilitzar-lo per realitzar subtraccions sense portar-ne, amb el minuend i el subtrahend col·locats verticalment $i$ horitzontal}

En la 3a fase d'E-A de la subtracció i quan es presente a l'aula una situació en la qual siga necessari restar amb el minuend i el subtrahend de més d'una xifra, serà el moment d'introduir els algorismes d'aquesta operació (no es necessita per tal de restar dos nombres d'una xifra).

A continuació es proposa la primera part d'una seqüència didàctica ordenada per nivells de dificultat segons la qual s'haurien d'introduir els algorismes de l'operació en el 1r i 2 n cicle d'Educació Primària.

Començarem per la subtracció sense portar-ne (cap de les xifres del minuend és menor que la corresponent del subtrahend) que pot recórrer els trams següents:

1. Subtracció de dos nombres de dues xifres: $25-13$.

2. D'un de dues xifres amb un altre d'una: $13-5$.

3. De dos nombres de tres xifres: $325-124$.

4. D'un de tres xifres amb un altre d'una o dues xifres: $325-4,325-24$. 
Treballarem la construcció d'aquest algorisme, per a la seua comprensió i posterior automatització, amb l'ajuda dels materials didàctics que ja coneixen (com són els BM i els àbacs) i la transcripció escrita de les accions que fan.

Suposem que es presenta a classe una situació problemàtica com la següent: «Ens trobem a la classe de $1 \mathrm{r}$ de Primària i comptem amb 27 euros per comprar material escolar. Si gastem 12 euros en paper, quants ens quedaran per a bolígrafs, gomes, etc.?».

Es comentarà amb ells com trobar la resposta al problema i arribarem a la conclusió que cal resoldre la subtracció de 27 menys 12, però no la saben calcular numèricament encara perquè els seus termes són de dues xifres $i$ ja no es troben a la taula de la subtracció.

Després que diferents membres de l'alumnat presenten les seues propostes de resolució de l'operació i en la recerca de la manera comuna de fer-ho, introduirem l'algorisme estàndard corresponent.

Fent ús dels materials didàctics, al cas dels BM, per al 27, tindran dos reglets i set cubs, i per al 12, un reglet i dos cubs. Si utilitzen dos àbacs verticals, en el primer representaran el minuend que serà el $27 \mathrm{i}$ en el segon el subtrahend, el 12. Es representa en la figura 53 aquesta ajuda, per exemple amb els àbacs.
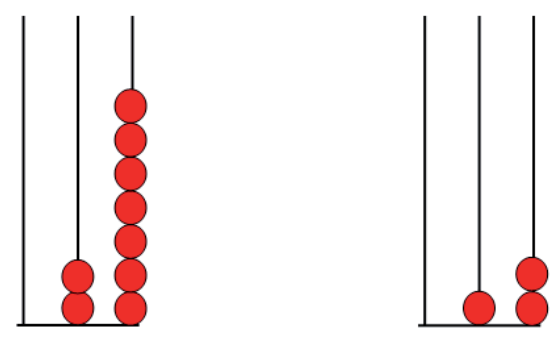

Figura 53. Representació de 27 i 12 amb àbacs

Abans de continuar amb la manipulació dels materials es comenta amb l'alumnat la necessitat d'expressar per escrit el que ocorre numèricament per tenir la memòria del procés que s'està portant $\mathrm{i}$ del resultat final. Per tal d'indicar les desenes $\mathrm{i}$ les unitats a l'hora de simbolitzar l'operació, podem utilitzar, si escau, les expressions amb unitats separades:

$$
\begin{gathered}
2[10] 7 \\
-1[10] 2 \\
\hline ? ?
\end{gathered}
$$

Els preguntem què haurien de fer per obtenir el resultat final. Amb els BM ho resolen llevant, un a un, els cubs i els reglets del 12 alhora que lleven la mateixa quantitat, respectivament, en el 27. A continuació ens diuen el que queda del 27, quan del 12 ja no hi haja cap peça. El resultat és un reglet i cinc cubs; és a dir, 15. El procés 
ha consistit a retirar la mateixa quantitat de peces iguals dels dos termes fins que en el subtrahend no quede cap peça, verbalitzant en tot moment el que fan.

En el cas dels àbacs hauran d'anar llevant igual quantitat de boles de les mateixes posicions en els dos àbacs fins que a l'àbac del subtrahend no quede cap bola (figura 54).
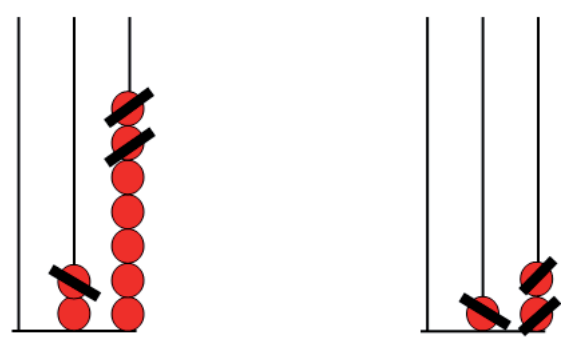

Figura 54. Representació del procés de la subtracció: 27 - 12

Quan del subtrahend no en quede cap, a l'àbac del minuend estarà representat el resultat final de l'operació. En finalitzar la tasca, trobaran 5 boles a la vareta de les unitats i 1 en la de les desenes com es mostra en la figura 55. Per tant, el resultat és el nombre 15.
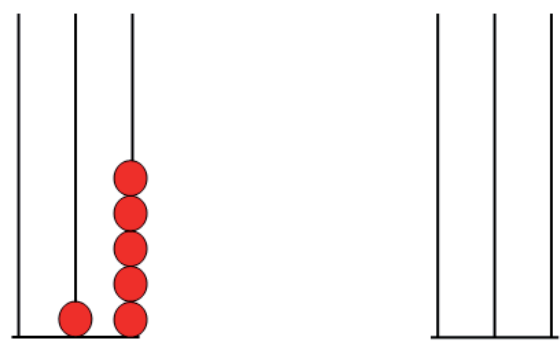

Figura 55. Representació amb àbacs del resultat de $27-12$

També es podria realitzar l'operació utilitzant un àbac només i aplicant el procediment adient. Representen el 27, que és el minuend i en lleven 12, és a dir, lleven dues boles de la primera vareta i una de la següent començant per la dreta. El nombre que queda representat és el 15.

De manera simultània a la manipulació amb qualsevol dels materials i la corresponent verbalització, treballarem la representació simbòlica amb les xifres:

$$
\begin{array}{r}
2[10] 7 \\
-\underbrace{1[10] 2}_{15} \\
\hline \underbrace{1[10] 5}_{15}
\end{array}
$$

Quan l'alumnat deixe de necessitar les unitats separades per entendre l'operació, 27

s'escriurà la subtracció en l'expressió usual: -12 . 
La comprensió clara de les xifres que representen cada tipus d'unitats farà que la col·locació dels termes de la subtracció en columna siga correcta, sense necessitar les expressions amb unitats separades. No s'hauria de passar a la disposició horitzontal $(27-12=15)$ fins que no estiga clara la representació vertical.

Per a tornar al context del treball, respondrem a la pregunta de la situació problemàtica de partida: «Ens trobem a la classe de 1r de Primària i compten amb 27 euros per comprar material escolar. Si gastem 12 euros en paper, ens quedaran 15 per a bolígrafs, gomes, etc.».

S'han de fer més exemples de subtracció reflexionant amb l'alumnat sobre la relació de les xifres del minuend i subtrahend i les de la resta o diferència, ajudant-los a què mitjançant les situacions problemàtiques treballades arriben a la conclusió: «la xifra de les unitats del resultat és la diferència entre les xifres de les unitats del minuend i subtrahend, i la xifra de les desenes del resultat és la diferència entre les xifres de les desenes dels esmentats termes». D'aquesta manera l'alumnat observa que s'ha transformat una subtracció de nombres de dues xifres en dues subtraccions de nombres d'una xifra, que ja sabien resoldre. I així descobreixen com funciona l'algorisme usual de la subtracció sense portar-ne.

Numèricament se seguirà un procediment semblant per restar sense portar-ne en els diferents trams de la seqüència didàctica proposada.

En 1r cicle de Primària ha de quedar assolit aquest algorisme, i així no hi haurà problemes amb la subtracció sense portar-ne quan treballem amb nombres més grans en cursos posteriors, tant si l'operació es realitza en disposició vertical com horitzontal.

L'objectiu final serà arribar a usar aquest algorisme de la subtracció amb l'expressió usual dels termes com la manera natural de resoldre les subtraccions associades a la resolució de situacions problemàtiques.

Una vegada està assolida la subtracció sense portar-ne i ja en 2n de Primària, és el moment per superar la barrera que els separa del repte següent: resoldre el problema que suposa la subtracció de nombres, quan en algun ordre d'unitats la xifra del minuend és menor que la corresponent del subtrahend, la qual cosa vol dir que cal fer una subtracció «portant-ne».

Proposem ara la segona part de la seqüència didàctica ordenada per nivells de dificultat segons la qual s'haurien d'introduir els algorismes (natural i estàndard) de l'operació en el 1r i 2n cicle d'Educació Primària i que es refereix a la subtracció portant-ne:

1. Subtracció portant-ne en les unitats, per exemple: $52-35,23-5,545-$ $-439,335-28$..

2. En les desenes únicament: $325-82,525-431 \ldots$

3. En les unitats i desenes: $532-285,436-69 \ldots$

4. En les centenes i ordres superiors: $1375-747,12715-4972 \ldots$ 
B.9. Descobrir l'algorisme natural de la subtracció portant-ne i utilitzar-lo per realitzar subtraccions portant-ne, amb el minuend i el subtrahend col-locats verticalment $i$ horitzontal

Seguim en la 3 a fase d'E-A de la subtracció i a continuació presentem, per a 2 n curs de Primària, la construcció de l'algorisme natural de la subtracció portant-ne, que consisteix a demanar prestada en el minuend una unitat a la xifra de l'ordre següent al que trobem la dificultat per restar i afegir-la a la xifra problemàtica descomposta en 10 unitats del seu ordre.

Tal com s'ha treballat en algorismes anteriors, per la construcció, comprensió i posterior automatització, s'utilitzaran materials didàctics que ja coneixen (com són els BM i els àbacs) i la transcripció numèrica de les accions que fan.

Suposem que es presenta a classe una situació problemàtica com la següent «Ens trobem a la classe de $2 \mathrm{n}$ de Primària i de 45 llibres que té una col·lecció de contes a l'aula n'hi ha 28 . Volem saber quants en queden a la biblioteca del col·legi, sense haver d'anar-hi»».

Després que diferents membres de l'alumnat presenten les seues propostes de resolució de l'operació i en la recerca d'una manera comuna de fer-ho, introduirem l'algorisme natural de la subtracció portant-ne.

La idea és que es puguen construir l'algorisme a partir de la manipulació dels materials esmentats, reflexionant els passos que els conduiran a trobar la solució.

El primer pas serà representar els nombres 45 i 28 amb els materials didàctics que estiguen utilitzant. De la mateixa manera que en els exemples anteriors, per al cas dels BM trien 4 reglets i 5 cubs per al 45, i dos reglets i vuit cubs per al 28 (figura 56). Si utilitzen dos àbacs verticals, en el primer representaran el minuend que serà el $45 \mathrm{i}$ en el segon el subtrahend, el 28.
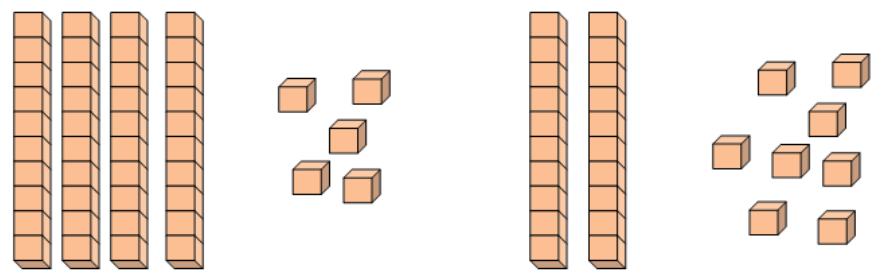

Figura 56. Representació de 45 i 28 amb BM

Per guardar registre numèric del que fan i de manera anàloga als casos anteriors, els demanem que representen l'operació de la següent manera:

$$
\begin{gathered}
4[10] 5 \\
-\quad 2[10] 8 \\
\hline ? ?
\end{gathered}
$$


Quan intenten resoldre l'operació, observen que no tenen 8 cubs o 8 boletes per llevar de les unitats del minuend i dediquen temps a pensar per resoldre aquest problema.

El coneixement de l'sND els farà arribar, sense massa ajuda, a fer-se la pregunta: «Podem agafar un reglet dels quatre que tenim i substituir-lo per deu cubs o una bola de la vareta de les desenes i substituir-la per deu boles de la vareta de les unitats?». A partir de donar una resposta afirmativa a aquesta pregunta, els queda clar el que han de fer: demanar prestada una desena en el minuend i descompondre-la en 10 unitats per afegir-les a les unitats d'aquest terme (figura 57).
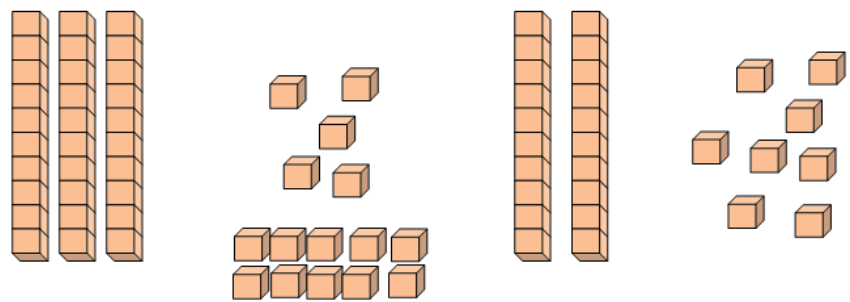

Figura 57. Representació de la transformació d'una desena del 45 en 10 unitats

Els 10 cubs transformats o les 10 boles de la vareta de les unitats dels àbacs converteixen en 15 les unitats del minuend. Ara sí que poden llevar 8 unitats dels dos termes, a banda de llevar després les dues desenes (figura 58).
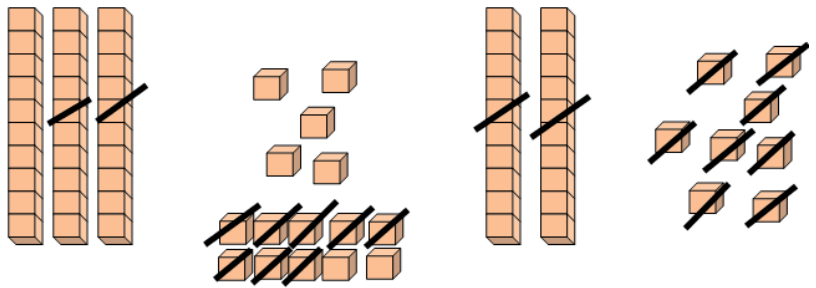

Figura 58. Representació del procés de la subtracció de 45 menys 28

El resultat obtingut serà $17 \mathrm{i}$, per tant, verbalitzaran quaranta-cinc menys vint-ivuit són dèsset. Aquest resultat el poden traslladar a l'expressió numèrica següent:

$$
\begin{array}{r}
4310] 15 \\
-2[10] 8 \\
\hline \underbrace{1[10] 7}_{17}
\end{array} .
$$

Aquest és el procediment que anomenem algorisme natural, de descomposició o de préstec perquè, com hem dit abans i acabem de posar en pràctica, consisteix a demanar prestada en el minuend una unitat a la xifra de l'ordre següent al qual trobem la dificultat per restar i afegir-la a la xifra problemàtica descomposta en 10 unitats del seu ordre. 
Quan l'alumnat deixe de necessitar les unitats separades per entendre l'algorisme, s'escriurà la subtracció en l'expressió usual:

$$
\begin{gathered}
4^{3} 5 \\
-28 \\
\hline 17
\end{gathered}
$$

on indiquem la transformació feta i les deu unitats que s'afigen a les unitats del minuend s'anoten de manera gràfica amb un 1 més menut a sobre de la columna de les unitats en posició exponencial-anterior.

La comprensió clara de les xifres que representen cada tipus d'unitats farà que la col·locació dels termes de la subtracció en columna siga correcta, sense necessitar les expressions amb unitats separades. No s'hauria de passar a la disposició horitzontal $(45-28=17)$ fins que no estiga clara la representació vertical.

Una vegada s'ha obtingut la solució de l'operació es proporciona la contestació a la situació problemàtica plantejada: «Dels 45 llibres que té una col·lecció de contes, a l'aula n'hi ha 28. En queden, per tant, 17 a la biblioteca del col-legi».

S'han de fer més exemples de subtracció reflexionant amb l'alumnat sobre la relació de les xifres del minuend i subtrahend i les de la resta o diferència, ajudant-los a què mitjançant les situacions problemàtiques treballades arriben a la conclusió: «si la xifra de les unitats del minuend és menor que la corresponent del subtrahend transformem una desena del minuend en deu unitats que afegim a les unitats del minuend, aleshores procedim com si fóra una subtracció sense portar-ne». I així descobreixen com funciona l'algorisme natural de la subtracció en aquests casos.

Se seguirà un procediment semblant per restar portant-ne en les desenes amb nombres de tres xifres i intentarem que per restar portant-ne en unitats i en desenes no siga necessària la utilització dels materials.

A continuació es mostra un exemple de representació numèrica d'una subtracció portant en les desenes, 554 -362, que es realitzarà amb unitats separades, si escau:

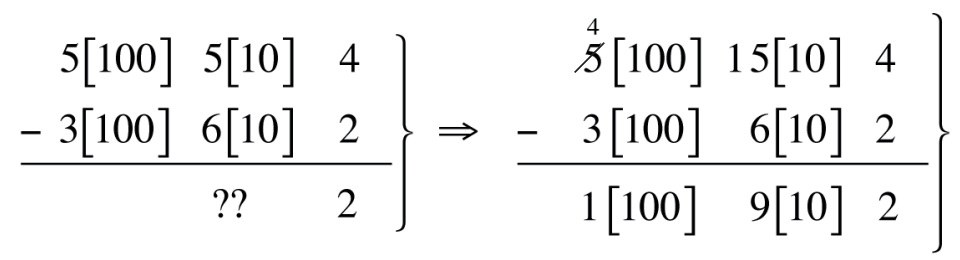

$$
\begin{aligned}
& \begin{array}{lll}
5^{4} & 1 & 5
\end{array}
\end{aligned}
$$

o directament amb l'expressió definitiva de l'algorisme natural: $\frac{-362}{192}$.

Es faran més exemples de subtraccions associades a la resolució de situacions problemàtiques, fins que els alumnes utilitzen aquest algorisme com la manera usual de resoldre les subtraccions portant-ne. 
B.10.Descobrir l'algorisme estàndard de la subtracció portant-ne i utilitzar-lo per realitzar subtraccions portant-ne, amb el minuend i el subtrahend col-locats verticalment $i$ horitzontal

Aquest algorisme, anomenat també usual o habitual, s'introdueix com una continuació de l'anterior, després de comprovar que l'algorisme natural pot resultar complicat en subtraccions amb gran quantitat de zeros en el minuend, com per exemple 20.003-1.956. A banda d'aquesta raó més pràctica, n'hi ha d'altres, com l'estès ús social d'aquest algorisme i la normativa vigent, que indica la necessitat de treballar els algorismes estàndard.

A partir de situacions problemàtiques que necessiten una subtracció per tal de resoldre-les, s'introduirà aquest algorisme amb l'ajuda del teorema de les subtraccions equivalents, també anomenat propietat de la compensació.

A continuació passem a treballar el teorema:

Suposem que es presenta a classe una situació problemàtica com la següent: «Manel conta als companys i companyes: tinc 13 contes d'una col·lecció de 20 contes, quants me'n queden per completar-la? Aquest cap de setmana en compraré dos més, però m'he assabentat que l'editorial ha decidit augmentar la col·lecció en dos volums. Quants me'n falten ara per completar-la?».

Els companys de classe procedeixen a resoldre la situació plantejada per Manel:

- Contes que li falten ara: $20-13=7$.

- Contes que li faltaran després del cap de setmana: $(20+2)-(13+2)=22-15$ $=7$.

El resultat de la 2a subtracció no ha variat.

Les subtraccions $22-15$ i $20-13$ per tenir el mateix resultat s'anomenen subtraccions equivalents.

Es faran més exemples de subtraccions associades a la resolució de situacions problemàtiques d'aquest tipus, reflexionant amb l'alumnat sobre la relació dels dos resultats obtinguts, ajudant-los a què arriben a la conclusió: «si augmentem o disminuïm en la mateixa quantitat els dos termes de la subtracció la diferència no varia».

Aquest fet es coneix amb el nom de teorema o propietat de les subtraccions equivalents, i és la base teòrica de l'algorisme estàndard o habitual de la subtracció portant-ne.

L'expressió formal del teorema o propietat és:

$$
\forall a, b, c \in N / a \geq b \geq c:(a \pm c)-(b \pm c)=a-b .
$$

Quan els xiquets i les xiquetes hagen interioritzat aquesta propietat de les subtraccions, serà el moment d'introduir l'algorisme estàndard de la subtracció portant-ne. 
Estem a la 3a fase d'E-A de la subtracció, però a 3r curs de Primària. Per treballar la comprensió i l'automatització de l'algorisme, utilitzarem els materials didàctics que ja coneixen (com són els blocs multibase i els àbacs) i la transcripció escrita de les operacions que realitzen.

Suposem que es presenta a classe una situació problemàtica com la següent «Ens trobem a la classe de $3 \mathrm{r}$ de Primària i de 45 llibres que té una col-lecció de contes, a l'aula n'hi ha 28. Volem saber quants en queden a la biblioteca, sense haver d'anar-hi».

Es comentarà amb ells com trobar la resposta a la situació i arribaran a la conclusió que cal resoldre la subtracció de 45 menys 28. Després que diferents membres de l'alumnat presenten les seues propostes de resolució de l'operació i en la recerca d'una manera comuna de fer-ho, introduirem l'algorisme estàndard corresponent.

Fent ús dels materials didàctics, al cas dels BM, per al 45, tindran quatre reglets $\mathrm{i}$ cinc cubs, i per al 28, dos reglets i vuit cubs. Si utilitzen dos àbacs verticals, en el primer representaran el minuend que serà el 45 i en el segon el subtrahend, el 28. Es representa en la figura 59 aquesta ajuda amb els àbacs.
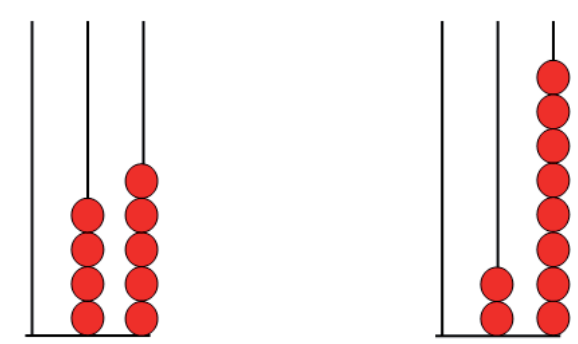

Figura 59. Representació de 45 i 28 amb àbacs

Abans de continuar amb la manipulació dels materials es comenta amb l'alumnat la necessitat d'expressar per escrit el que ocorre numèricament per tenir la memòria del procés que es portarà i del resultat final. Per tal d'indicar les desenes i les unitats a l'hora de simbolitzar l'operació, poden utilitzar, si s'escau, les expressions amb unitats separades:

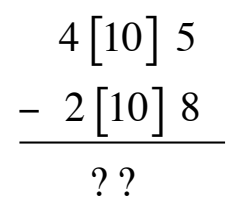

Els preguntem què haurien de fer per obtenir el resultat final i observen que no poden llevar les 8 unitats del subtrahend a les unitats del minuend, dedicant temps a pensar per resoldre aquest problema. Com que han après l'algorisme natural proposen descompondre una desena del minuend en deu unitats i afegir-les a les que ja tenia aquest terme. Els diem que la condició per operar ara és que no poden transformar desenes en unitats, que han de buscar un altre procediment per resoldre l'operació. 
Dediquen temps a pensar. És més complicat i, en un primer moment, amb la referència de l'algorisme natural, com el problema de no poder llevar se'ls presenta en les unitats, pel cas dels BM ho resolen afegint 10 cubs a la representació del minuend (que és el 45). Preguntem a l'alumnat si aquesta acció modificarà el resultat. Ajudant-los en la reflexió i la recerca de la resposta, intueixen que sí, aleshores hem de continuar fent alguna cosa per tal que el resultat no varie i recordant el teorema de les subtraccions equivalents, arriben a la conclusió d'afegir també la mateixa quantitat de cubs al subtrahend (que és el 28), per la qual cosa en el minuend tenim 4 reglets $i 15$ cubs, i en el subtrahend 2 reglets i 18 cubs.

Anàlogament, en el cas dels àbacs procedirien afegint 10 boles en les unitats de la representació del minuend i perquè el resultat no varie afegirien també 10 boles en les unitats del subtrahend, com es mostra en la figura 60.
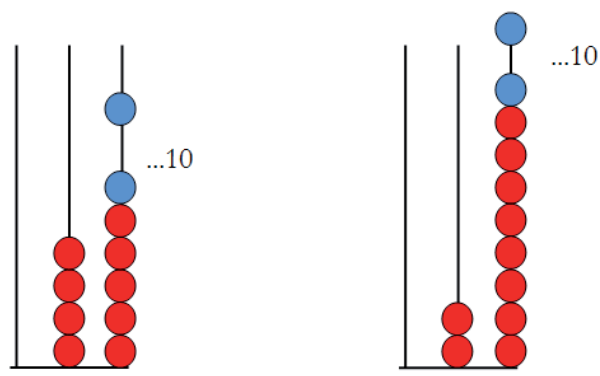

Figura 60. Representació amb àbacs de com s'afigen 10 unitats als termes de $45-28$

De manera simultània al treball amb qualsevol dels dos materials, verbalitzen el que ha passat $\mathrm{i}$ ho representen numèricament:

$$
\begin{array}{r}
4[10] 15 \\
-2[10] 18 \\
\hline ? ?
\end{array}
$$

Comproven que les unitats afegides no són la solució perquè així continuen tenint més unitats en el subtrahend que en el minuend. Pel bon coneixement que tenen del funcionament de l'sND i per solucionar la situació, en el cas dels BM transformen els 10 cubs del subtrahend en un reglet i l'afigen a les desenes, així sí tenim major quantitat d'unitats en el minuend per poder restar, concretament, tenim 4 reglets i 15 cubs, i en el subtrahend $2+1$ reglets i 8 cubs. En els àbacs, anàlogament al treball fet amb els BM, arriben a transformar les 10 boles que s'havien afegit a les unitats del subtrahend en una bola a la vareta de les desenes del mateix terme. Es representa en la figura 61 el resultat de la transformació amb els àbacs.
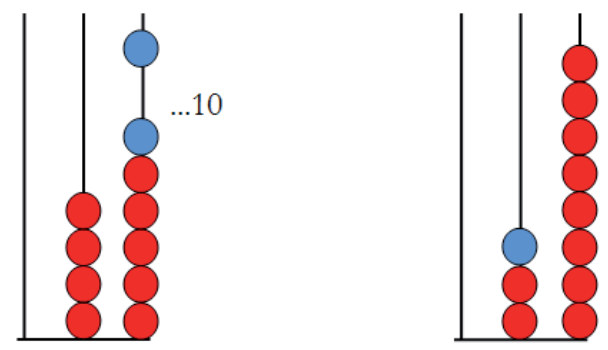

Figura 61. Representació amb àbacs de la transformació de 10 unitats en una desena en el subtrahend 
Amb l'alumnat, simultàniament a la manipulació amb els materials, verbalitzarem el que ha passat $\mathrm{i}$ ho representaran numèricament:

$$
\begin{array}{r}
4[10] 15 \\
-2+1[10] 8 \\
\hline ? ?
\end{array}
$$

En els BM ara sí que poden retirar 8 cubs d'ambdós termes de la subtracció, i ens queden del minuend sols 7 cubs, aleshores quinze menys vuit fan set. Als àbacs lleven boles de la vareta de les unitats dels dos àbacs al mateix temps fins que no en quede cap al subtrahend, com es mostra en la figura 62 .
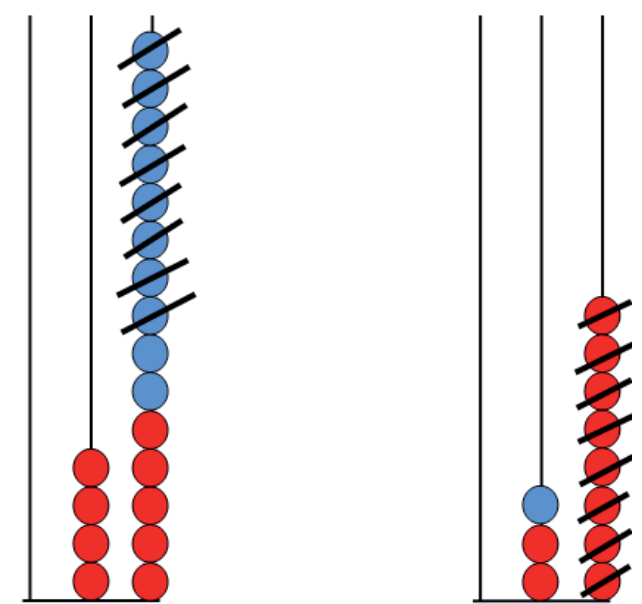

Figura 62. Representació amb àbacs de la subtracció en les unitats

Combinat amb el treball de manipulació dels materials i la corresponent verbalització, es realitza la representació simbòlica amb les xifres, per tal de fixar què s'ha fet:

$$
\begin{array}{r}
4[10] 15 \\
-2+1[10] \quad 8 \\
\hline 7
\end{array}
$$

Per acabar la manipulació dels BM i completar el procés, llevaran dels dos termes la quantitat de barres que ara hi ha en el subtrahend, és a dir, 4 menys 3 fan 1. Ja tenim el resultat, un reglet i set cubs, dèsset, aleshores quaranta-cinc menys vint-ivuit fan dèsset. En els àbacs, lleven una a una boles de la vareta de les desenes del subtrahend i del minuend fins que del subtrahend desapareguen totes, $i$ els queda en el minuend sols una bola, és a dir, 4 menys 3 fan 1 . Ja tenim el resultat, una bola i set boles a les últimes varetes de la dreta, respectivament, com es mostra en la figura 63 . 


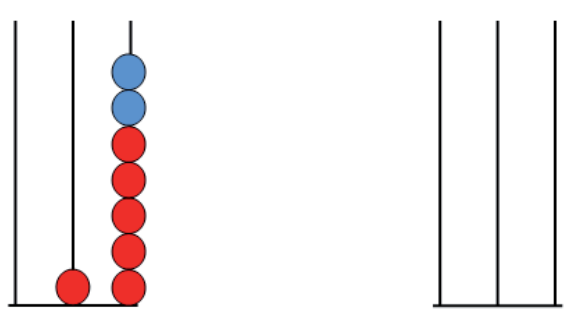

Figura 63. Representació en àbacs del resultat de $45-28$

Simultàniament a la manipulació amb qualsevol dels materials i la corresponent verbalització, treballarem la representació simbòlica amb les xifres:

$$
\begin{array}{r}
4[10] 15 \\
-2+1[10] 8 \\
\hline 1[10] 7
\end{array}
$$

Quan l'alumnat deixe de necessitar les unitats separades per entendre l'operació, s'escriurà la subtracció en l'expressió usual, inicialment amb ajudes:

$$
4{ }^{1} 5
$$

$$
\frac{-2}{2+1}_{17}
$$

on les deu unitats que s'afigen a les unitats del minuend es fa notar manera gràfica amb un 1 més menut a sobre de la columna de les unitats en posició exponencialanterior i la desena afegida al subtrahend amb un més 1 en posició exponencial.

La comprensió clara de les xifres que representen cada tipus d'unitats farà que la col·locació dels termes de la subtracció en columna siga correcta, sense necessitar les expressions amb unitats separades. No s'hauria de passar a la disposició horitzontal $(45-28=17)$ fins que no estiga clara la representació vertical.

Per tornar al context del treball, respondrem a la pregunta de la situació problemàtica de partida: «Dels 45 llibres que té una col-lecció de contes i que a l'aula n'hi ha 28 , en queden a la biblioteca del col-legi $17 »$.

S'han de fer més exemples de subtracció reflexionant amb l'alumnat sobre la relació de les xifres del minuend i subtrahend i les de la resta o diferència, ajudant-los a què mitjançant les situacions problemàtiques treballades arriben a la conclusió que en les subtraccions portant-ne en les unitats: «afegir la mateixa quantitat de la mateixa forma (10 unitats) al minuend $\mathrm{i}$ al subtrahend és un pas inútil».

A partir d'aquest moment, i possiblement sense necessitat d'utilitzar els materials, en les següents subtraccions aplicaran el que acaben de descobrir, i afegiran directament 10 unitats a la representació del minuend i 1 desena a la del subtrahend. D'aquesta manera aconsegueixen transformar la subtracció portant-ne en una altra sense portar-ne. La representació simbòlica (amb unitats separades, si escau) seria: 


$$
\begin{array}{r}
4[10] 15 \\
-2+1[10] 8 \\
\hline 7
\end{array}
$$

Els passos següents d'aquest treball es desenvoluparan de manera semblant al que s'ha explicat anteriorment (finalitzar l'operació, recontextualitzar...).

En la reflexió amb l'alumnat sobre la relació de les xifres dels termes i les del resultat, els ajudarem a què mitjançant els exemples treballats arriben a una conclusió semblant a: «si la xifra de les unitats del minuend és menor que la corresponent del subtrahend afegim deu unitats a les unitats del minuend i una desena a les desenes del subtrahend, aleshores procedim com si fóra una subtracció sense portar-ne». Han descobert com funciona aquest procediment que anomenem algorisme estàndard per a subtraccions portant-ne en les unitats.

L'objectiu final serà arribar a usar l'algorisme estàndard amb l'expressió usual dels termes de la subtracció, com la manera habitual de resoldre les subtraccions portant-ne, en les quals les unitats que s'afigen i la desena que es porta es recordaran de manera mental.

En 3r curs de Primària, se seguirà un procediment semblant per restar portant-ne en les desenes amb nombres de tres xifres i intentarem que per restar portant-ne en unitats $\mathrm{i}$ en desenes no siga necessària la utilització dels materials.

Per tal de veure-ho en unitats i desenes, desenvolupem l'exemple següent, 751 - 362 que es realitzarà amb unitats separades, si escau:

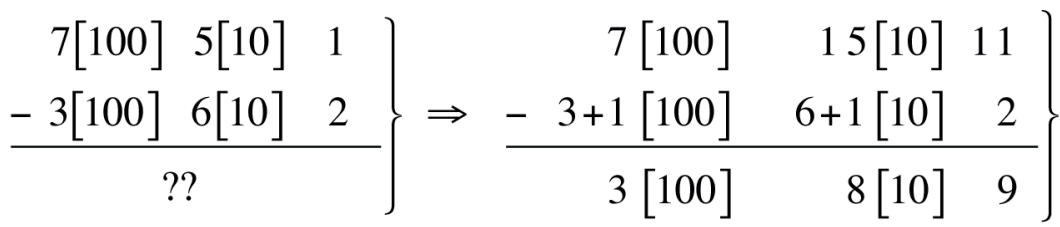

o directament amb l'expressió definitiva de l'algorisme estàndard: - 362 .

389

En 3r curs de Primària ha de quedar assolit el funcionament d'aquest algorisme, $\mathrm{i}$ així no hi haurà problemes amb l'algorisme estàndard de la subtracció portant-ne quan treballen amb nombres més grans en cursos posteriors i generalitzen el seu ús, tant si l'operació es realitza en disposició vertical com horitzontal.

\section{B.11. Desenvolupar l'agilitat mental en el càlcul de la subtracció}

De manera espontània, i fent servir el mateix procediment que en l'addició, en veu alta, dins d'un joc, en diferents situacions... i sempre en un nivell de menys 
dificultat del que a classe es treballe en l'àmbit simbòlic, utilitzarem la subtracció per treballar el càlcul mental. Cal treballar el fet de restar sense haver d'usar llapis i paper. De fet, és un altre dels càlculs més relacionat amb la vida real juntament amb l'addició, perquè al carrer i a casa, en situacions extraescolars, és on més addicions i subtraccions faran.

En 1r cicle de Primària, es treballarà la taula de la subtracció, subtraccions de dues xifres, començant amb desenes completes, i com que a classe s'ha treballat la descomposició polinòmica, utilitzarem aquesta eina per al càlcul mental. Així, si, per exemple, se'ls demana restar $29-5$, mentalment haurien de pensar «29 és $20+9$ $\rightarrow 9-5=4$, aleshores $29-5=24 »$.

Anàlogament al cas de l'addició, cal estar atents també a totes les estratègies emergents que apareixen en els xiquets i xiquetes, a la construcció de la seua pròpia manera de calcular mentalment $i$ als instruments de suport explicitats en la capacitat A.8. Per exemple, si un xiquet o xiqueta ha de restar $15-9$, és possible que li resulte més fàcil restar $15-10$ i al resultat afegir-ne 1 ; o assumir que el $9=5+4$ i per tant els és més fàcil restar $15-5 \mathrm{i}$ al resultat restar-ne 4 . Aquestes maneres «personals» de restar comporten conèixer la composició dels nombres de manera additiva i arribar a veure una determinada quantitat en funció d'algunes descomposicions, més útils, que tinga. Per exemple, el $100=25+25+25+25$, aquelles «quatre vegades 25» els fa arribar ràpidament als 100, 75, 50, 25. $\mathrm{O}$ el $60=$ $15+15+15+15$ i per tant, arribar ràpidament a $60,45,30,15$, etc.

A mesura que es va dominant aquest càlcul mental i es treballen les altres operacions, es pot combinar gradualment la subtracció amb elles per tal de fer un treball conjunt.

\section{B.12. Resoldre i inventar situacions problemàtiques relacionades amb la subtracció}

És en situacions reals on cobra especial sentit el treball fet amb aquesta operació, perquè realment és la realitat la que origina interrogants la resposta dels quals passarà per saber, en aquest cas, resoldre subtraccions.

Com al cas de l'addició, encara que la resolució i la invenció de problemes apareix com la quarta fase per treballar les operacions, també ara ens hi trobem des del principi, perquè presentem les subtraccions de manera contextualitzada, a partir de situacions reals que han de resoldre's i que, igualment, estaran relacionades amb qualsevol bloc de continguts matemàtics.

Continuarem treballant la resolució de problemes a partir de les quatre fases de Polya i de la reflexió amb l'alumnat sobre la seua importància, desenvolupament i utilitat.

Com s'ha comentat en la capacitat A.9 i amb les mateixes consideracions, aprofitarem els errors per generar nous aprenentatges i continuarem amb el treball d'estimació dels resultats de les situacions problemàtiques. 
Iniciarem el treball en 1r de Primària, amb problemes que necessiten ser resolts amb una subtracció. És molt important que, en els primers moments, prestem atenció de manera individual a cadascuna de les diferents situacions utilitzades per introduir l'operació (de disminuir, d'afegir per arribar a una nova quantitat, de comparar cardinals). Així, cada vegada que introduïm un nou tipus de situacions per a la subtracció, haurem de treballar la resolució de problemes relacionats amb elles, per reforçar el significat de l'operació que tenen associat. Quan ja reconeguen la subtracció com l'operació que serveix per resoldre qualsevol d'aquestes situacions, plantejarem problemes relacionats amb elles sense tenir cura que apareguen de manera aïllada.

Més endavant i encara en el 1r cicle treballarem problemes que necessiten dues subtraccions per ser resolt. Els problemes esmentats fins ara seran de nombres de dues xifres, per passar a $2 \mathrm{n}$ de Primària amb nombres de tres xifres.

També i a dins d'aquest $1 \mathrm{r}$ cicle, es poden proposar problemes que necessiten per ser resolts la combinació d'una subtracció i una addició.

En referència als enunciats de les situacions problemàtiques seguirem els mateixos passos que per a l'addició (capacitat A.9) però haurem de fer una consideració afegida. Es tracta de la necessitat que dins dels enunciats clars, ordenats, complets, sense errors..., tinguem cura al principi de fer aparèixer les dades de manera ordenada d'acord amb el seu paper en la subtracció que han de realitzar, és a dir, que el primer nombre siga el minuend i el segon el subtrahend («Si tens 25 euros i gastes 12 en uns cromos, quants te'n queden?»). Avançat el cicle no serà necessari respectar aquest ordre («Si has gastat 12 euros en cromos i tenies 25, quants te'n queden?»).

En aquest cas, l'aparició de problemes amb enunciats confusos, incomplets, amb dades que falten, amb dades que sobren... haurà de ser un poc més retardada que en el treball amb l'addició.

Desenvoluparem també tasques d'invenció de problemes relacionats amb la subtracció amb les mateixes orientacions donades per a l'addició (capacitat A.9), tant referides a l'oferiment d'ajudes a l'alumnat com a la necessitat d'intercanviar entre els xiquets i les xiquetes els enunciats inventats. Com a detall diferent ressaltarem la necessitat de treballar la invenció dels tres tipus de situacions relacionades amb la subtracció. Així, quan els proposem que inventen una situació i els donem els nombres, el context, etc., podem demanar-los també que la situació siga de disminuir, d'afegir per a arribar a una nova quantitat o de comparar cardinals per comprovar si han captat el significat de l'operació en totes les vessants i són capaços de generar situacions relacionades amb totes elles.

En els cicles posteriors es continuaran les tasques de resolució i invenció de situacions problemàtiques relacionades amb la subtracció, en les quals aquesta operació es combinarà amb les altres tres a mesura que les vagen dominant. Haurem de procurar al llarg de tota l'etapa que les situacions treballades es referisquen sempre als tres tipus de situacions problemàtiques relacionades amb aquesta operació. 
Cap al final del $1 \mathrm{r}$ cicle o ja en el $2 \mathrm{n}$ hem de treballar amb l'alumnat el fet que qualsevol addició genera sempre dues subtraccions, de manera que els tres nombres queden relacionats amb les operacions addició i subtracció de la manera següent:

$$
\forall a, b, c \in N: a+b=c \Leftrightarrow c-a=b \wedge c-b=a .
$$

La traducció a situacions reals per als xiquets podria ser:

«Tinc 13 contes d'una col·lecció. Me’n regalen 7 més i ja està completa. Quants contes formen la collecció?» $13+7=20$.

«Tinc 13 contes per completar la col-lecció de 20, quants me'n falten? $20-13=7$.

«Em queden 7 contes per completar la col·lecció de 20, quants en tinc?» $20-7=13$.

Tant en una subtracció com en l'altra, el nombre de contes que tinc més el nombre de contes que em falten, fan el nombre de contes de la col·lecció, que és la primera addició que hem calculat. Aleshores també podem escriure l'expressió anterior de la manera següent:

$$
\forall a, b, c \in N: c-a=b \wedge c-b=a \Leftrightarrow a+b=c .
$$

Es faran més exemples de subtraccions associades a la resolució de situacions problemàtiques, reflexionant amb l'alumnat al voltant d'aquest fet, ajudant-los a què arriben com a conclusió a la norma general: «el minuend és igual al subtrahend més la diferència».

A partir d'aquest moment, amb la finalitat d'aconseguir que l'alumnat es puga sentir «matemàtic» (Chevallard i altres, 1997) i responsable de la correcció dels seus resultats, s'utilitzaran aquestes relacions com a forma de comprovar si les subtraccions estan ben fetes.

\section{B.13. Realitzar exercicis pràctics de subtraccions en el sistema de numeració sexagesimal}

Anàlogament a l'addició, aquesta capacitat es treballarà en el 3r cicle de Primària. S'introduirà una vegada que quede clara l'operació anterior en el sistema sexagesimal, fent subtraccions sense portar-ne, i posteriorment portant-ne, en els segons, en els minuts, en ambdós al mateix temps. L'algorisme que s'utilitzarà serà el natural o de préstec.

La subtracció sense portar-ne en el sistema sexagesimal es realitzarà restant per separat cadascun dels ordres de les unitats com es pot veure en l'exemple següent:

$25 \mathrm{~h} 15 \min 19 \mathrm{~s}$

$$
\begin{array}{r}
-10 \mathrm{~h} 43 \mathrm{~min} 7 \mathrm{~s} \\
\underline{15 \mathrm{~h} 12 \min 12 \mathrm{~s}} \\
\hline
\end{array}
$$


Recordem la convivència de les xifres indoaràbigues i els ordres de les unitats del sistema sexagesimal, i la necessitat de tenir present aquest fet per a la comprensió de l'algorisme de la subtracció en aquest sistema.

Cal incidir amb l'alumnat en què el fet de portar-ne ocorre en aquest cas quan alguna de les quantitats que apareixen en els dos primers ordres d'unitats del minuend és menor que la corresponent del subtrahend. Resoldrem aquestes operacions utilitzant l'algorisme natural de la subtracció portant-ne sense arribar a l'estàndard i a la memorització de «portar-ne una» per la poca freqüència amb què necessitem aquestes operacions i per evitar el treball mental amb nombres tan grans.

A continuació presentem un exemple de subtracció en el sistema sexagesimal, portant-ne en els segons, en el qual representem de manera numèrica el procés de l'operació i els canvis necessaris per arribar al resultat final correcte:

$$
\begin{array}{r}
54 \mathrm{~min} 79 \mathrm{~s} \\
25 \mathrm{~h} 55 \mathrm{~min} 19 \mathrm{~s} \\
-10 \mathrm{~h} 42 \mathrm{~min} 57 \mathrm{~s} \\
\hline 15 \mathrm{~h} 12 \mathrm{~min} 22 \mathrm{~s}
\end{array}
$$

Anàlogament, es mostra ara un exemple de subtracció en el sistema sexagesimal, portant-ne en els segons i en els minuts:

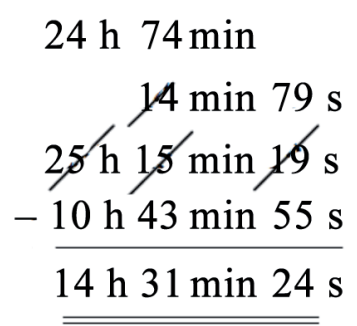

En aquest cas el procediment serà també anàleg quan treballem amb quantitats referents a la amplitud angular.

\section{Multiplicació}

La noció de multiplicació de nombres naturals va lligada al concepte de conjunt; per tant, és vàlid el que s'ha vist en el tema anterior i que fa referència a aquest concepte.

Atenent a la definició, la multiplicació és l'operació que ens permet calcular el producte de dos nombres, entenent que aquest és el cardinal del conjunt que resulta de construir el producte cartesià de dos conjunts que tenen com a cardinals els nombres que multiplicarem. 
Per resultar més intuïtiva la idea, amb l'alumnat de Primària entendrem en un principi la multiplicació com l'operació que deriva d'una addició en la qual els sumands són tots iguals. Des d'aquest punt de vista, per ser una operació nascuda directament de l'addició, està també relacionada amb la teoria de conjunts, entenent en aquest cas el producte com el cardinal del conjunt que resulta de la unió d'un nombre de conjunts disjunts i equipotents igual a un dels nombres a multiplicar, el cardinal dels quals és l'altre nombre que es multiplica. Recordem que per conjunts disjunts s'entén aquells que no comparteixen elements, i per equipotents, aquells que tenen el mateix cardinal.

\section{C.1. Construir la idea de multiplicació a partir de la unió de conjunts disjunts equipotents, expressant els cardinals respectius $i$ simbolitzant les addicions de sumands iguals realitzades}

En aquesta capacitat desenvolupem el treball corresponent a la primera de les fases d'E-A de la multiplicació, que es realitza en el 2n curs de l'etapa.

Cal partir d'activitats pràctiques i manipulatives per recrear situacions que puguen identificar ràpidament. Les situacions que hem de presentar són aquelles en les quals apareguen addicions amb tots els sumands iguals i en què ens interesse trobar un nou mètode per calcular el resultat.

Per exemple, «En la classe de $2 \mathrm{n}$ hem fet grups de 3 xiquets i xiquetes. Cadascun dels alumnes ha de retallar 6 figures d'animals per al mural de la granja. Quantes figures tindrà cada grup?». Per respondre a la pregunta reuniran les figures dels tres membres del grup, les comptaran i ens diran que tenen divuit figures. Mentalment no han pensat «sis per tres igual a divuit», simplement han comptat el que tenen a les mans.

Els proposarem que ens expliquen verbalment el que ha passat amb les figures retallades, insistint en la relació de la situació amb una addició de sumands iguals i en la utilització dels nombres que hi han intervingut. Amb la intenció de fer més curtes les frases que utilitzen, els ajudarem a modificar l'enunciat «hem ajuntat sis figures d'Anna, sis de Josep i sis de Marga i ara tenim divuit figures», passant per «sis més sis més sis és igual a divuit», fins a arribar a «sumem el sis tres vegades i ens dóna divuit», on ja apareixen els dos termes que intervenen en la multiplicació.

Acompanyant la verbalització, i per les mateixes raons que en les operacions anteriors, podem proposar-los una representació gràfica (figura 64) del que ha ocorregut, en la qual apareguen els nombres en la seua expressió matemàtica,

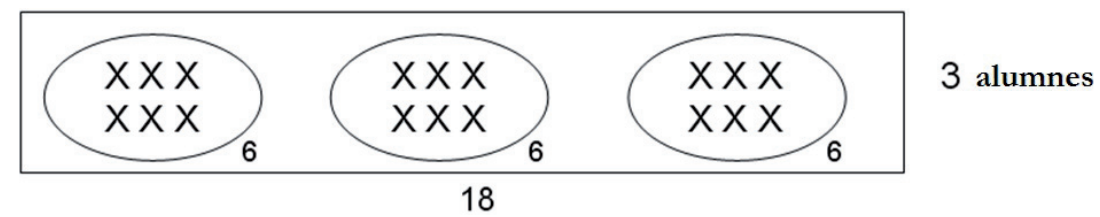

Figura 64. Representació de la unió de 3 conjunts de 6 elements 
amb la qual cosa ens anirem apropant un poc més a la representació numèrica del que ha passat amb els objectes.

De manera anàloga a les altres operacions, els preguntarem com es podria escriure tot això sols amb els nombres, per arribar a la representació d'una addició de sumands iguals:

6

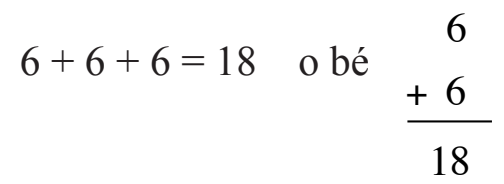

Relacionat amb aquestes addicions introduirem la paraula multiplicació, i hauríem d'aconseguir que l'evolució verbal en els exemples fóra: si el 6 el sumem repetidament 3 vegades, obtenim el 18. Posteriorment, tinc el 6 repetit 3 vegades, és a dir, tinc 18. Continuarem amb 6 multiplicat per 3 fan 18. Al final, s'hauria de dir: 6 per 3 fan 18.

El final de la fase serà demanar als xiquets i xiquetes que siguen ells qui troben o reconeguen situacions de la seua vida personal que estiguen relacionades amb l'operació (diners, joguets, llapis de colors...).

C.2. Utilitzar els signes « $\times » i$ «=» per expressar, mitjançant una multiplicació, una addició de sumands iguals. Identificar i utilitzar correctament els termes i signes de la multiplicació

Continuant en el $2 \mathrm{n}$ curs, una vegada realitzades les accions anteriors $\mathrm{i}$ coneguda la paraula multiplicació, és el moment de passar a la segona fase d'E-A de l'operació, introduint els símbols « $\mathrm{x} » \mathrm{i} \ll=»$; aleshores, l'enunciat verbal «sis per tres fan divuit» es canvia per l'enunciat numèric $« 6 \times 3=18 »$, en un primer moment de

manera horitzontal, que canviarem posteriorment a la disposició vertical $\times 3$ per facilitar més endavant l'aprenentatge de l'algorisme.

Però el que ha de quedar clar és que aquesta nova operació deriva de l'addició de 6 sumands iguals: 6 .

$$
\frac{+6}{18}
$$

Introduirem també la nomenclatura específica d'aquesta operació: el 6 s'anomena multiplicand (nombre que es repeteix), el 3 multiplicador (quantitat de vegades que es repeteix) i el 18, producte. El signe « $x »$ es llegeix per, i el signe «=», igual (que ja el coneixien).

Cal notar que, a diferència de les operacions anteriors, en aquesta els dos termes no són qualitativament iguals. El multiplicand fa referència al nombre d'elements 
dels conjunts equipotents (compta elements), i el multiplicador al nombre d'aquests conjunts (compta conjunts). Usualment s'escriurà en primer lloc el multiplicand, i en segon, el multiplicador.

Quan coneguen tots els termes i signes de les restants operacions, haurem de comprovar que l'alumnat els identifica i diferencia correctament.

\section{C.3 Realitzar multiplicacions de nombres utilitzant addicions de sumands iguals}

És important que després d'haver introduït l'expressió simbòlica de l'operació, aquesta no es desconnecte de les accions amb les quals es relaciona. Per això, també en el 2 n curs i en moments posteriors al treball de la capacitat anterior, caldrà mostrarlos expressions simbòliques de multiplicacions que hauran de calcular mitjançant reunions de conjunts disjunts equipotents o a partir d'addicions de sumands iguals.

Aquest és un treball invers al realitzat en les dues capacitats anteriors, en les quals l'alumnat avançava des de les accions amb els objectes fins a les expressions numèriques de les situacions.

Si els xiquets i les xiquetes són capaços de trobar els resultats de les multiplicacions propostes sense recórrer als objectes o a les addicions, poden resoldre-les numèricament d'aquesta manera, però haurem de reflexionar-hi sobre el significat de l'operació i sobre la seua relació inequívoca amb situacions en les quals es reuneixen conjunts disjunts equipotents $i$ es resolen addicions de sumands iguals.

\section{C.4 Construir la taula de multiplicar}

Simultàniament al treball de manipulació d'objectes quotidians, en els quals hauran reunit conjunts disjunts amb el mateix cardinal de diverses maneres i, per tal de recollir els resultats de les multiplicacions realitzades, poden emplenar una graella en la qual es recullen els productes bàsics i que dóna per resultat la taula següent:

\begin{tabular}{|c|c|c|c|c|c|c|c|c|c|}
\hline$\times$ & 1 & 2 & 3 & 4 & 5 & 6 & 7 & 8 & 9 \\
\hline 1 & 1 & 2 & 3 & 4 & 5 & 6 & 7 & 8 & 9 \\
\hline 2 & 2 & 4 & 6 & 8 & 10 & 12 & 14 & 16 & 18 \\
\hline 3 & 3 & 6 & 9 & 12 & 15 & 18 & 21 & 24 & 27 \\
\hline 4 & 4 & 8 & 12 & 16 & 20 & 24 & 28 & 32 & 36 \\
\hline 5 & 5 & 10 & 15 & 20 & 25 & 30 & 35 & 40 & 45 \\
\hline 6 & 6 & 12 & 18 & 24 & 30 & 36 & 42 & 48 & 54 \\
\hline 7 & 7 & 14 & 21 & 28 & 35 & 42 & 49 & 56 & 63 \\
\hline 8 & 8 & 16 & 24 & 32 & 40 & 48 & 56 & 64 & 72 \\
\hline 9 & 9 & 18 & 27 & 36 & 45 & 54 & 63 & 72 & 81 \\
\hline
\end{tabular}

Caldrà aconseguir que entre el $2 \mathrm{n}$ i el $3 \mathrm{r}$ curs l'alumnat siga capaç de memoritzar aquests resultats per facilitar els càlculs amb la multiplicació. 


\section{C.5. Descobrir l'algorisme de la multiplicació per una xifra i utilitzar-lo per realitzar multiplicacions en les quals augmente progressivament el nombre de xifres del multiplicand}

En la 3a fase d'E-A de la multiplicació i quan es presente a l'aula una situació en la qual siga necessari multiplicar amb el multiplicand de més d'una xifra, serà el moment d'introduir l'algorisme d'aquesta operació (no es necessita per tal de multiplicar dos nombres d'una xifra).

A continuació es proposa la primera part d'una seqüència didàctica ordenada per nivells de dificultat segons la qual s'haurien d'introduir els algorismes de l'operació a final del 1ri en el 2n cicle d'Educació Primària.

Començarem per multiplicacions amb multiplicands de més d'una xifra i multiplicadors d'una sola, en les quals es poden recórrer els trams següents:

1. Multiplicació sense portar-ne amb multiplicand de dues xifres: $12 \times 3$.

2. Portant-ne amb multiplicand de dues xifres: $25 \times 3$.

3. De tres xifres: $341 \times 2,725 \times 3$.

4. Multiplicand amb qualsevol quantitat de xifres.

Treballarem la construcció d'aquest algorisme, per a la seua comprensió i posterior automatització, amb l'ajuda dels materials didàctics que ja coneixen (com són els BM i els àbacs) i la transcripció escrita de les accions que fan.

Suposem que es presenta a classe una situació problemàtica com la següent: «Ens trobem a la classe de $2 \mathrm{n}$ de Primària i estem organitzant un cap de setmana en una granja escola, en la qual les habitacions són triples. Si cada alumne ha d'aportar $12 €$ per al viatge, quant costa cada habitació?».

Es comentarà amb l'alumnat com trobar la resposta i arribarem a la conclusió que cal resoldre la multiplicació de 12 per 3 , però no la saben calcular numèricament encara perquè un dels termes és de dues xifres i ja no es troba a la taula de la multiplicació.

Abans de continuar amb la manipulació dels materials, es comenta amb l'alumnat la necessitat d'expressar per escrit el que ocorre numèricament per tenir la memòria del procés que es portarà i del resultat final. Per tal d'indicar les desenes i les unitats a l'hora de simbolitzar l'operació, poden utilitzar, si escau, les expressions amb unitats separades:

$$
\begin{array}{r}
1[10] 2 \\
\times \quad 3 \\
\hline ? ?
\end{array}
$$


Després que diferents membres de l'alumnat presenten les seues propostes de resolució de l'operació i en la recerca de la manera comuna de fer-ho, introduirem l'algorisme estàndard corresponent.

Fent ús dels materials didàctics, al cas dels BM, per al 12, tindran un reglet i dos cubs, repetits tres vegades, i diferenciats. Si utilitzen àbacs verticals, representaran el multiplicand tres vegades, una en cadascun.

Seguidament, agrupen el material i donen el resultat, 36. Què ha passat? Als BM s'ha triplicat el nombre de cubs i també el de reglets del multiplicand, al cas dels àbacs també, però de les boles corresponents en cada vareta d'un d'aquests. Cal, aleshores, representar amb material des del principi 3 vegades el 12? (aquesta pregunta és la transposició de «cal buscar el resultat com si es fera una addició de sumands iguals»). Ho pensen i arriben a la conclusió que no, que és suficient representar-lo una vegada i aleshores triplicar primer els cubs i després els reglets en els BM o les boles corresponents en cada vareta d'un sol l'àbac. Estan construint l'algorisme de la multiplicació per un nombre d'una xifra començant per les unitats de primer ordre.

De manera simultània a la manipulació amb els materials i la verbalització corresponent, farem la representació numèrica, amb unitats separades si escau:

$$
\begin{array}{r}
1[10] 2 \\
\times \quad 3 \\
\hline \underbrace{3[10] 6}_{36}
\end{array}
$$

L'objectiu final serà arribar a usar l'expressió usual de l'algorisme: $\times \underline{3}$.

Per tornar al context de treball, respondrem a la pregunta de la situació problemàtica de partida: «Ens trobem a la classe de $2 \mathrm{n}$ de Primària $\mathrm{i}$ estem organitzant un cap de setmana en una granja escola, en la qual les habitacions són triples. Si cada alumne ha d'aportar $12 €$ per al viatge, cada habitació costa $36 € »$.

S'han de fer més exemples de multiplicació reflexionant amb l'alumnat sobre la relació de les xifres del multiplicand i multiplicador i les del producte o resultat, ajudant-los a què arriben a una conclusió semblant a: «per multiplicar un nombre de dues xifres per un altre d'una sola, es multiplica aquest nombre per la xifra de les unitats i posteriorment per la de les desenes, s'obtenen, respectivament, les xifres de les unitats i les desenes del resultat». S'ha convertit una multiplicació amb un multiplicand de dues xifres que no se sabia resoldre, en dues multiplicacions de nombres d'una xifra que sí que saben fer.

Numèricament se seguirà un procediment semblant per multiplicar sense portar-ne en els diferents trams de la seqüència didàctica proposada. 
En 2n curs de Primària ha de quedar assolit aquest algorisme i així no hi haurà problemes en les multiplicacions de multiplicands de més xifres, tant si l'operació es realitza en disposició vertical com horitzontal.

L'objectiu final serà arribar a usar aquest algorisme de la multiplicació amb l'expressió usual dels termes com la manera natural de resoldre les multiplicacions per una xifra sense portar-ne associades a la resolució de situacions problemàtiques.

Continuem en 2n de Primària amb el pas següent en l'algorisme d'aquesta operació introduint multiplicacions per una xifra, però ara portant-ne.

Novament, treballarem la construcció d'aquest algorisme, per a la seua comprensió i posterior automatització, amb l'ajuda dels materials didàctics que ja coneixen i la transcripció escrita de les accions que fan.

Suposem que es presenta a classe una situació problemàtica com la següent: «Ens trobem a la classe de $2 \mathrm{n}$ de Primària i estem organitzant un cap de setmana en una estació d'esquí, en la qual les habitacions són triples. Si cada alumne ha d'aportar $25 €$ per a l'allotjament, quant costa cada habitació?».

Es comentarà amb l'alumnat com trobar la resposta i arribarem a la conclusió que cal resoldre la multiplicació de 25 per 3 , però no la saben calcular numèricament encara perquè en multiplicar la xifra de les unitats obtenen un resultat superior a 9.

Abans de continuar amb la manipulació dels materials es comenta amb l'alumnat la necessitat d'expressar per escrit el que ocorre numèricament. Utilitzarem, si escau, les expressions amb unitats separades:

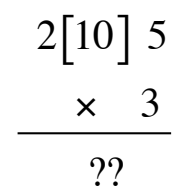

Després que diferents membres de l'alumnat presenten les seues propostes de resolució de l'operació i en la recerca de la manera comuna de fer-ho, introduirem l'algorisme estàndard corresponent.

Fent ús dels materials didàctics, al cas dels BM, agafaran dos reglets i cinc cubs. Triplicaran els cubs i els reglets successivament. En intentar expressar el resultat, s'adonen que tenen 6 reglets i 15 cubs. Al cas dels àbacs, representaran el nombre 25 i de manera semblant que al cas anterior, triplicaran les boles de les varetes de les unitats i de les desenes (figura 65). 


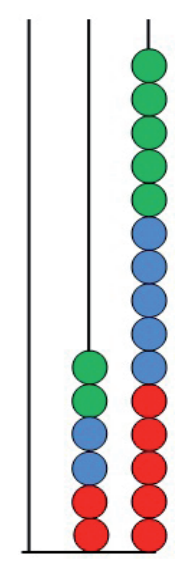

Figura 65. Representació del resultat de triplicar 25 amb un àbac

De manera simultània al treball amb qualsevol dels dos materials, verbalitzen el que ha passat $\mathrm{i}$ ho representen numèricament:

$$
\begin{array}{r}
2[10] 5 \\
\times \quad 3 \\
\hline 6[10] 15
\end{array}
$$

Anàlogament al cas de l'addició, transformen 10 unitats en 1 desena i l'afigen a la multiplicació de les desenes, «n'han portat una». Amb els materials implica substituir els cubs per reglets en el cas dels BM o canviar boles i situar-les a les varetes adients, en el cas dels àbacs (figura 66).
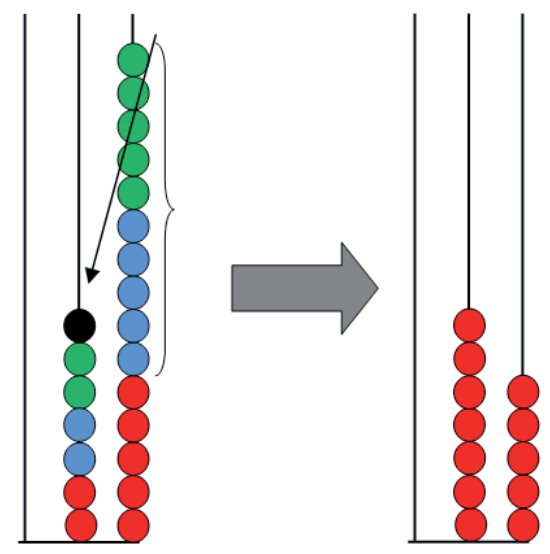

Figura 66. Representació del resultat de multiplicar 25 per 3 amb un àbac

A continuació mostrem de manera detallada els canvis numèrics que acompanyen la manipulació dels materials:

$$
\begin{array}{r}
\begin{array}{c}
2[10] 5 \\
\times \quad 3
\end{array} \\
\underbrace{6[10] \underbrace{15}_{110] 5}}_{\underbrace{[10] 5}_{75}}
\end{array}
$$


Amb l'alumnat, simultàniament a la manipulació amb els materials i la corresponent verbalització, modificarem la representació simbòlica del resultat, i arribarem a l'expressió:

$$
\begin{array}{r}
\begin{array}{r}
1 \\
{[10] 5} \\
\times 3 \\
\hline 7[10] 5
\end{array} \\
\hline
\end{array}
$$

on la desena que resulta de la multiplicació de les unitats i que s'afig a les desenes («n'hem portat una»), es pot recordar de manera gràfica amb un 1 més menut a sobre de la columna de les desenes.

Quan l'alumnat deixe de necessitar les unitats separades per entendre l'operació, s'escriurà la multiplicació en l'expressió estàndard:

$$
\begin{array}{r}
25 \\
\times 3 \\
\hline 75
\end{array}
$$

Per tornar al context de treball, respondrem a la pregunta de la situació problemàtica de partida: «Ens trobem a la classe de 2 n de Primària i estem organitzant un cap de setmana en una estació d'esquí, en la qual les habitacions són triples. Si cada alumne ha d'aportar $25 €$ per a l'allotjament, cada habitació costa $75 €$ ».

S'han de fer més exemples de multiplicació reflexionant amb l'alumnat sobre la relació de les xifres del multiplicand i multiplicador i les del producte o resultat, per ajudar als alumnes a arribar a una conclusió semblant a la següent: «es multiplica de dreta a esquerra i la xifra de les unitats del producte és la xifra de les unitats del resultat de multiplicar les unitats del multiplicand i la xifra de les desenes del producte és el resultat de multiplicar les desenes del multiplicand i afegir-li la o les desenes que es porten».

A partir d'aquest moment, i possiblement sense necessitat d'utilitzar els materials, en les següents multiplicacions aplicaran de manera numèrica el que acaben d'aprendre.

En $2 n$ cicle de Primària ha de quedar assolit aquest algorisme, i així no hi haurà problemes amb la multiplicació per una xifra de nombres amb més xifres que realitzaran en cursos posteriors, tant si l'operació es realitza en disposició vertical com horitzontal.

L'objectiu final serà arribar a usar l'algorisme esmentat de la multiplicació amb l'expressió usual dels termes com la manera natural de resoldre les multiplicacions portant-ne associades a la resolució de situacions problemàtiques. 


\section{C.6. Identificar nombres parells i imparells}

Cap al final del 1r cicle d'Educació Primària i relacionat amb l'aprenentatge de les diferents columnes de la taula de multiplicar, haurem d'observar amb l'alumnat que alguns nombres sempre es poden obtenir multiplicant un altre nombre per 2, mentre que la resta no poden obtenir-se mai d'aquesta manera. Serà el moment d'introduir els conceptes de nombre parell i nombre imparell, respectivament.

Aprofitarem alguna situació real en la qual apareguen els nombres organitzats per aquesta característica (numeració dels edificis en un carrer, de les butaques en un cinema...) per insistir en la diferència entre els dos tipus de nombres i completarem el seu coneixement quan a $3 \mathrm{r}$ curs es treballe la divisió i es puguen reconèixer els parells com els nombres que poden dividir-se per 2 de manera exacta i els imparells com els que no poden fer-ho. D'aquesta manera classifiquem els Nombres Naturals en dos subconjunts complementaris.

En treballar la divisibilitat en els Nombres Naturals, s'ampliaran aquests conceptes, i es relacionaran els nombres parells amb els múltiples de dos i els imparells amb la resta.

\section{C.7. Comprovar les propietats commutativa, associativa i distributiva de la multiplicació. Reconèixer $i$ aplicar aquestes propietats}

Per treballar aquesta capacitat, ens situarem en $2 \mathrm{n}$ cicle de Primària. Es pot pensar que les propietats de la multiplicació semblen conclusions de l'operació una vegada ja s'ha assolit aquesta, però la realitat ens fa utilitzar-les per introduir alguns aspectes de l'operació, per exemple, la multiplicació per un nombre de dues xifres. Estudiarem amb l'alumnat les propietats commutativa i associativa de la multiplicació, a més de la distributiva de la multiplicació respecte de l'addició. En qualsevol dels casos la introducció a l'aula es duria a terme de manera gradual, amb exemples de nombres que representen poca quantitat i augmentant la dificultat a poc a poc.

\section{Propietat commutativa de la multiplicació}

«L'ordre dels factors no altera el producte» o, el que és el mateix, l'operació de la multiplicació permet obtenir el mateix resultat independentment de l'ordre de colllocació dels factors. En llenguatge matemàtic: $\forall a, b \in N \rightarrow a \times b=b \times a$.

En el moment d'introduir aquesta propietat, es produeix un fenomen propi de la multiplicació: el canvi de noms de multiplicand i multiplicador, per factors. Al principi tenia sentit diferenciar, perquè el multiplicador indicava el nombre de vegades que se sumava el multiplicand. Però aquest nou pas en l'abstracció implica comprendre que la quantitat d'elements utilitzats és la mateixa si per exemple regalem 3 joguets a cadascun dels 4 xiquets o 4 joguets a cadascuna de les 3 xiquetes. 
És per això que el mot factor suposarà simplificar la nomenclatura; mai han de pensar que aquest canvi implica una complicació afegida a l'operació.

Els exemples que s'utilitzaran i el fet de fer servir la taula de multiplicacions per una xifra, han de ser suficients per assolir aquesta propietat. La manera d'expressar els dos resultats de l'exemple anterior serà: $3 \times 4=12$ i $4 \times 3=12$. A continuació expressaran la igualtat de resultats de la manera següent: $3 \times 4=12=4 \times 3$, i finalment: $3 \times 4=4 \times 3$. Es repeteixen més vegades situacions semblants, fins que es puga considerar una propietat general.

L'absència de resultat en l'expressió simbòlica requereix un esforç mental més gran. Arribar al fet que es comprenga que l'objectiu no era trobar un resultat, 12, sinó més aviat que hi ha dos camins per arribar-hi, és el repte, igual que passava amb la propietat commutativa de l'addició.

Ha de quedar clar, novament, que el mot commutar significa canviar l'ordre, però com que no és la primera vegada que veuen aquesta propietat, poden assolir-la més ràpidament. Aleshores caldrà diferenciar l'operació i no caure en la confusió de barrejar les propietats commutatives de l'addició i la multiplicació.

Encara que probablement ha aparegut de manera intuitiva aquesta propietat en $1 \mathrm{r}$ cicle de Primària, en construir la taula de l'operació, és avançat el $2 \mathrm{n}$ cicle quan caldrà treballar-la específicament amb exemples senzills on apareguen les situacions, però en diferent ordre de multiplicació... Una activitat interessant és proposar una llista on hi haja parelles de problemes amb el mateix resultat, però amb dos factors iguals en ordre de multiplicador i multiplicand diferent, a l'estil del que es feia en l'addició. Es farien tots, i per concloure es reconeixerà la propietat, i se'ls farà conscients que no cal resoldre el segon de cada parella, perquè aquesta operació ja estava feta.

L'objectiu posterior serà saber aplicar la propietat. En plantejar una llista semblant a l'anterior, han de reconèixer les parelles de problemes i decidir no resoldre el segon de cada parella, perquè ja en saben la solució.

Posteriorment els proposem les dues multiplicacions i que inventen enunciats o situacions reals on les solucions siguen les maneres indicades de multiplicar els dos nombres; darrerament els alumnes inventaran situacions problemàtiques per usar la propietat commutativa de la multiplicació sense cap indicació de quines multiplicacions han d'usar.

Nota: Aplicació de la propietat commutativa per justificar les multiplicacions $4 \times 1$ i $4 \times 0$.

Si es fa ús de la definició, no hi ha lògica. El cas de $4 \times 1$ vol dir que multipliquem el 4 per 1, és a dir, que el sumem una vegada. Hi ha addicions d'un sumand? Ens poden preguntar... 
En el cas de $4 \times 0$, encara és més dramàtica la pregunta: «Hi ha addicions de cap sumand?». I molt més la resposta que els donem: «El resultat és zero».

Però utilitzant la propietat commutativa en els dos casos, es poden transformar aquestes multiplicacions en d'altres que tenen més sentit:

$4 \times 1=1 \times 4=1+1+1+1=4$.

$4 \times 0=0 \times 4=0+0+0+0=0$.

Ara ja té un poc més de lògica i, d'aquesta manera, aconseguim que incorporen els resultats d'aquestes multiplicacions als seus coneixements sobre l'operació.

\section{Propietat associativa de la multiplicació}

«La manera d'agrupar tres o més factors no altera el producte». En llenguatge matemàtic: $\forall a, b, c \in N \rightarrow(a \times b) \times c=a \times(b \times c)$.

Cal fer la mateixa reflexió que es va fer a la propietat associativa de l'addició. És important tenir en compte que aquesta propietat també requereix dos moments cognitius seqüenciats. Partirem d'una situació que exigirà la multiplicació de tres nombres i que serà interessant per l'alumnat amb la finalitat d'afavorir la propietat. Per exemple:

«A la biblioteca de l'aula hi ha 3 prestatgeries, amb 5 prestatges cadascuna. Si caben 7 llibres en cada prestatge, quants llibres hi caben en total?».

Es deixarà que els xiquets resolguen el problema lliurement $i$ es compararan els diferents procediments utilitzats, que tindran el mateix resultat. Podem trobar xiquets que hagen fet $3 \times 5=15$ i després $15 \times 7=105$, i d'altres que hagen fet $5 \times 7=35$ i després $3 \times 35=105$ (cal notar que aquesta darrera multiplicació la faran de la forma $35 \times 3$, perquè encara no saben multiplicar amb multiplicador de dues xifres). Si es donara el cas que no aparegueren les dues opcions, es plantejarien preguntes intermèdies per tal que apareguen: «Quants prestatges hi ha?», «quants llibres hi ha en total?». O bé, «quants llibres caben en cada prestatgeria?», «quants llibres hi ha en total?».

En aquesta, i en altres situacions, és important arribar a poder simbolitzar les dues multiplicacions que es realitzen en cadascun dels mètodes de resolució:

- Per a la 1a forma de resolució $3 \times 5=15 \quad 15 \times 7=105$.

- Per a la 2 a forma de resolució $5 \times 7=35 \quad 3 \times 35=105$.

En el $2 \mathrm{n}$ moment cognitiu i en tots els exemples que treballem cal arribar a simbolitzar les dues multiplicacions de cada mètode en una sola expressió:

- Per a la 1a forma de resolució $(3 \times 5) \times 7=105$.

- Per a la 2 a forma de resolució $3 \times(5 \times 7)=105$. 
A continuació expressaran la igualtat de resultats de la manera següent: $(3 \times 5) \times 7=105=3 \times(5 \times 7)$, i finalment: $(3 \times 5) \times 7=3 \times(5 \times 7)$. Es repeteixen més vegades situacions semblants, fins que es puga considerar una propietat general.

La reflexió anirà pel mateix camí que en la propietat anterior; no és tan important arribar al 105, ho és més descobrir que la manera d'associar els factors no altera el resultat.

Haurem d'insistir en la definició d'associar, que és agrupar seqüencialment els factors, però com que no és la primera vegada que veuen aquesta propietat, poden assolir-la més ràpidament. Aleshores caldrà diferenciar l'operació i no confondre les propietats associatives de l'addició i de la multiplicació.

L'esquema de treball de la propietat associativa a l'aula de Primària és semblant al de la commutativa. S'introduirà també en $4 \mathrm{t}$ curs de Primària, amb exemples senzills on apareguen situacions amb diferents maneres d'agrupar els factors. Una activitat interessant per reconèixer la propietat serà usar una llista de problemes on el resultat de la seqüenciació de les multiplicacions dels tres factors siga el mateix. Posteriorment, els xiquets han d'aplicar-la, i hauran de deixar de resoldre els problemes que pertanyen a parelles on un ja estiga resolt.

Per acabar treballarem la invenció de situacions problemàtiques relacionades amb la propietat associativa, de manera anàloga a com ho hem fet amb la commutativa.

\section{Propietat distributiva de la multiplicació respecte de l'addició}

«El resultat de multiplicar un factor per una suma de dos nombres és el mateix que la suma dels resultats de multiplicar aquest factor per cadascun dels sumands inicials». En llenguatge matemàtic: $\forall a, b, c \in N \rightarrow a \times(b+c)=(a \times b)+(a \times c)$.

A partir d'una situació concreta, afavorirem la propietat, per exemple: «Al quiosc venen llepolies a 9 cèntims cadascuna. Comprem 5 llepolies de maduixa i 6 de meló, quant paguem en total?».

Es deixarà que els xiquets resolguen el problema lliurement i es compararan els diferents procediments utilitzats, que tindran el mateix resultat. Podem trobar xiquets que hagen fet $9 \times 5=45$ i $9 \times 6=54$ i després $45+54=99$, i d'altres que hagen fet $5+6=11$ per a després multiplicar $11 \times 9=99$. Si es donara el cas que no aparegueren les dues opcions, es plantejarien preguntes intermèdies per tal que apareguen: «Quant costen les de maduixa?» «i les de meló?», «quant costen totes les llepolies?». $\mathrm{O}$ bé, «quantes llepolies comprem?», «quant costen totes?».

En aquesta, i altres situacions, és important arribar a poder simbolitzar les operacions que es realitzen en cadascun dels mètodes de resolució:

- Per a la 1a forma de resolució $5+6=11$

$9 \times 11=99$.

- Per a la 2a forma de resolució $9 \times 5=45$ i $9 \times 6=54 \quad 45+54=99$. 
En el 2n moment cognitiu i en tots els exemples que treballem, cal arribar a poder simbolitzar les operacions de cada mètode en una sola expressió (utilitzaran el parèntesi fins que tinguen clara la jerarquia operacional):

- Per a la la forma de resolució $9 \times(5+6)=99$.

- Per a la 2 a forma de resolució $(9 \times 5)+(9 \times 6)=99$.

A continuació expressaran la igualtat de resultats de la manera següent: $9 \times(5+6)$ $=99=(9 \times 5)+(9 \times 6)$, i acabarem expressant $9 \times(5+6)=(9 \times 5)+(9 \times 6)$. Es repeteixen més vegades situacions semblants, fins que es puga considerar una propietat general.

La reflexió anirà pel mateix camí que en la propietat anterior; no és tan important arribar al 99, ho és més descobrir que la manera d'operar no altera el resultat. Les multiplicacions poden aparèixer en qualsevol altre ordre $i$, com que ja coneixen la propietat commutativa, sabran que són vàlides igualment.

L'esquema de treball de la propietat distributiva a l'aula de Primària és semblant als anteriors i s'introduirà novament en $4 \mathrm{t}$ curs, amb exemples senzills on apareguen situacions en les quals puguen organitzar els nombres de manera diferent.

Una activitat interessant serà usar una llista de problemes on el resultat de les operacions dels tres nombres siga el mateix: $a \times(b+c)=(a \times b)+(a \times c)$. Posteriorment, els xiquets han de reconèixer i aplicar aquesta propietat, $\mathrm{i}$ han de deixar de resoldre els problemes que pertanyen a parelles on un ja estiga resolt.

Caldrà destinar especial dedicació a no confondre la propietat distributiva de la multiplicació respecte de l'addició, amb l'associativa de la multiplicació, per tal de no arribar a situacions de l'estil $\forall a, b, c \in N \rightarrow a \times(b \times c)=(a \times b) \times(a \times c)$, que, evidentment, no són certes.

És important que els estudiants de Primària utilitzen aquesta propietat per descobrir que quan un factor es repeteix en els sumands de moltes addicions es pot traure com a factor comú. Aquest fet els permetrà simplificar operacions aritmètiques $i$ possibilitarà un futur pensament algebraic.

Per acabar treballarem la invenció de situacions problemàtiques relacionades amb la propietat distributiva, de manera anàloga a com ho hem fet amb la commutativa $\mathrm{i}$ associativa.

C.8. Descobrir l'algorisme de la multiplicació per 10, 100, 1.000... i utilitzar-lo per realitzar gràficament i mentalment multiplicacions per la unitat seguida de zeros

Aquest tipus de multiplicació mereix un apartat especial, per la facilitat, i per la gran utilitat que té multiplicar per desenes completes, o centenes completes... 
En 3r de Primària, a partir d'una situació on calga multiplicar $3 \times 10$, s'introduirà aquesta multiplicació: «En el campionat escolar de bàsquet $3 \times 3$ hi participen 10 equips mixtos. Quants xiquets i xiquetes participen al campionat?». El coneixement que ja tenen de l'sND i la reflexió sobre la formació de desenes a partir de la repetició de 10 unitats justifica que el resultat d'aquesta multiplicació siga 3 desenes. L'expressió escrita serà 30 i s'obté afegint un zero a la dreta del multiplicand. Si hi ha cap alumne que amb aquesta reflexió no comprenga el procediment, es recorrerà als materials didàctics perquè ho aconseguisca.

Per tornar a contextualitzar l'operació, respondrem a la pregunta de la situació problemàtica de partida: «En el campionat escolar de bàsquet $3 \times 3$ hi participen 10 equips mixtos, en total participen trenta xiquets i xiquetes».

Ara demanem a l'alumnat que es fixe en els nombres que apareixen en l'expressió numèrica de l'operació, que hi busquen alguna relació, i arriben a la conclusió: «el producte és el nombre del multiplicand seguit del zero del multiplicador».

Es faran més exemples de multiplicar xifres per 10 reflexionant amb els xiquets i xiquetes sobre la relació de les xifres dels termes i les del producte i observaran la regla «el resultat de multiplicar una xifra per 10 s'obté afegint a la dreta de la xifra un zero».

Se seguirà un procediment semblant per multiplicar per 10 nombres de diverses xifres. El coneixement que ja tenen del sistema de numeració decimal i la reflexió sobre la formació de desenes a partir de la repetició de 10 unitats justificarà que el resultat d'aquestes multiplicacions siga el multiplicand seguit del zero del multiplicador.

Posteriorment es plantegen l'operació $3 \times 100$. Es pot obtenir el resultat fent una reflexió anàloga al cas anterior o utilitzant la propietat associativa de la multiplicació (que prèviament s'haurà treballat amb els xiquets).

- Per exemple, a partir d'una situació problemàtica: «Si en el campionat autonòmic de bàsquet $3 \times 3$ escolar hi participaren 100 equips mixtos. Quants xiquets i xiquetes participarien al campionat?».

- Utilitzant la propietat associativa de la multiplicació:

$$
3 \times 100=3 \times(10 \times 10)=(3 \times 10) \times 10=30 \times 10=300 \text {. }
$$

Per tornar a contextualitzar l'operació, respondrem a la pregunta de la situació problemàtica de partida: «Si en el campionat autonòmic de bàsquet $3 \times 3$ escolar participen 100 equips mixtos, en total hi participen tres-cents xiquets i xiquetes».

Es faran més exemples de multiplicar xifres per 100. Seguirem multiplicant per 100 nombres de diverses xifres i, fent que sempre els xiquets es fixen en els nombres que apareixen en l'expressió numèrica de l'operació, deduiran que «la multiplicació per 100 es fa afegint 2 zeros al final del multiplicand». 
Una vegada assolida la multiplicació per 100, els plantegem $3 \times 1.000$. Obtindran el resultat fent una reflexió anàloga als casos anteriors o utilitzant la propietat associativa de la multiplicació:

- A partir d'una situació problemàtica per exemple: «Si en el campionat estatal de bàsquet $3 \times 3$ escolar participaren 1.000 equips mixtos, quants xiquets i xiquetes participarien al campionat?».

- Utilitzant la propietat associativa de la multiplicació: $3 \times 1.000=3 \times(10 \times 100)=(3 \times 10) \times 100=30 \times 100=3.000$.

Per tornar a contextualitzar l'operació, respondrem a la pregunta de la situació problemàtica de partida: "Si en el campionat estatal de bàsquet $3 \times 3$ escolar participen 1.000 equips mixtos, en total hi participen tres mil xiquets i xiquetes».

Multiplicaran més nombres d'una xifra per 1.000 i se seguirà un procediment semblant per multiplicar per 1.000 nombres de diverses xifres. Farem que els xiquets es fixen en els nombres que apareixen en l'expressió numèrica de l'operació i deduiran que: «la multiplicació per 1.000 es fa afegint 3 zeros darrere del multiplicand».

Després de comprovar aquests casos particulars, i com a regla general, observaran que «el resultat de multiplicar un nombre per la unitat seguida de zeros s'obté afegint a la dreta del nombre la quantitat de zeros que acompanya la unitat» i, per tant, es pot operar de manera automàtica.

Una vegada està assolida la multiplicació sense portar-ne i ja en 3r de Primària, és el moment per superar la barrera que els separa del repte següent: resoldre el problema que suposa la multiplicació de nombres, quan en el multiplicador hi ha més d'una xifra.

Proposem ara la segona part de la seqüència didàctica ordenada per nivells de dificultat segons la qual s'hauria d'introduir l'algorisme estàndard de la multiplicació per multiplicadors de més d'una xifra:

1. Multiplicacions on el multiplicador té dues xifres amb una unitat en les desenes: $24 \times 13,524 \times 13$.

2. Multiplicador de dues xifres qualssevol: $24 \times 63,243 \times 56$.

3. Multiplicador de qualssevol nombre de xifres.

\section{C.9. Descobrir l'algorisme de la multiplicació de dos nombres de diverses xifres i utilitzar-lo per realitzar multiplicacions de dificultat creixent}

Seguim en la 3a fase d'e-A de la multiplicació. Ens situem a 4t de Primària i una vegada assolida la multiplicació per una xifra serà el moment d'ampliar el coneixement de l'algorisme estàndard d'aquesta operació, presentant una situació en la qual siga necessari multiplicar amb un multiplicador de diverses xifres. 
Per resoldre multiplicacions on el multiplicador siga de dues xifres ja no és convenient treballar amb material didàctic, a causa de la gran quantitat de peces que s'hi necessitaria i de la dificultat de generar l'algorisme a partir de la manipulació. Una vegada arribat a aquest punt de la seqüència didàctica, passarem directament a la fase simbòlica i, per tant, farem servir llapis i paper.

Quan en la multiplicació el multiplicador és de vàries xifres, cal que els xiquets i xiquetes hagen treballat prèviament la descomposició polinòmica dels nombres naturals, la propietat distributiva de la multiplicació respecte de l'addició, la propietat associativa de la multiplicació i la multiplicació per la unitat seguida de zeros.

S'introduirà la multiplicació per dues xifres, començant amb una situació problemàtica en la qual siga necessari multiplicar per un nombre de dues xifres que tinga un 1 en les desenes. Per exemple: «Si els 24 xiquets i xiquetes de $4 \mathrm{t}$ de Primària, com una activitat d'educació física hem anat 13 vegades a la piscina en aquest trimestre, quantes entrades hem comprat?».

Comentarem amb ells com trobar la resposta i arribarem a la conclusió que cal resoldre la multiplicació de 24 per 13, però no la saben calcular numèricament encara.

Entre les seues propostes de resolució de l'operació, algunes podrien consistir a descompondre el multiplicador en 10 i 3, i fer dues multiplicacions diferenciades que sí que saben resoldre, sumant després els resultats. Per comprovar si aquestes propostes són vàlides, haurem de buscar-ne la justificació matemàtica, mitjançant la utilització dels requisits ja esmentats.

Entre tots i totes, intentarem expressar matemàticament els passos que ens condueixen a la resposta i que són els següents:

$$
24 \times 13=24 \times(10+3) \underset{\uparrow}{=}(24 \times 10)+(24 \times 3)=240+72=312 .
$$

\begin{tabular}{|l|l|l|}
\hline D. polinòmica & P. distributiva & Mult. per 10 \\
\hline
\end{tabular}

Per arribar a l'expressió estàndard, usual o habitual de l'algorisme, hauran de traslladar els passos de l'expressió anterior a la disposició vertical de l'algorisme, ja coneguda per les multiplicacions amb multiplicadors d'una xifra. Per realitzar aquest treball començarem per la dreta, i en primer lloc, escriuran el resultat de la multiplicació de les unitats del multiplicador pel multiplicand. A continuació anotaran davall de l'anterior el resultat de multiplicar la desena del multiplicador pel multiplicand i, finalment, sumaran ambdós resultats:

\begin{tabular}{rr}
24 \\
$\times \quad 13$ \\
\hline & 72 \\
24 & 0 \\
\hline 3 & 12
\end{tabular}


Per respondre a la pregunta de la situació problemàtica de partida, contestaran: « $\mathrm{Si}$ els vint-i-quatre xiquets i xiquetes de 4t de Primària, com una activitat d'Educació Física hem anat 13 vegades a la piscina en aquest trimestre, hem comprat trescentes dotze entrades»».

El pas següent de la seqüència didàctica ens exigeix resoldre una situació en la qual el multiplicador siga qualsevol nombre de dues xifres, igual o superior a 20. Per exemple, $24 \times 63$ : «Si els 24 xiquets i xiquetes de $4 \mathrm{t}$ de Primària, com una activitat d'educació física hem anat fins ara 63 vegades a la piscina en tots els anys de col·legi, quantes entrades hem comprat?».

Comentarem amb ells i elles com trobar la solució i ràpidament afirmen que cal fer la multiplicació de 24 per 63. En un procediment anàleg al cas anterior i aplicant a la multiplicació per 60 el que han après de la multiplicació per 10, arribaran a resoldre la multiplicació següent:

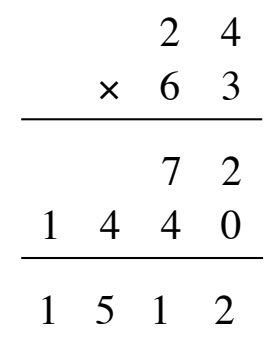

Si és que hi ha problemes amb la multiplicació de 24 per 60 , els farem notar que $60=6 \times 10 \mathrm{i}$ que per la propietat associativa de la multiplicació, tenim que $24 \times 60=24 \times(6 \times 10)=(24 \times 6) \times 10=144 \times 10=1.440$. Si és necessari es faran més exemples de multiplicar per desenes completes $i$, es reflexionarà amb l'alumnat al voltant dels nombres que apareixen en l'expressió de l'operació, per arribar a una expressió semblant a «el producte de multiplicar un nombre per desenes completes s'obté afegint un zero a la dreta del resultat de multiplicar el multiplicand per la xifra de les desenes».

La validesa d'aquest procediment, s'expressa matemàticament en els passos següents:

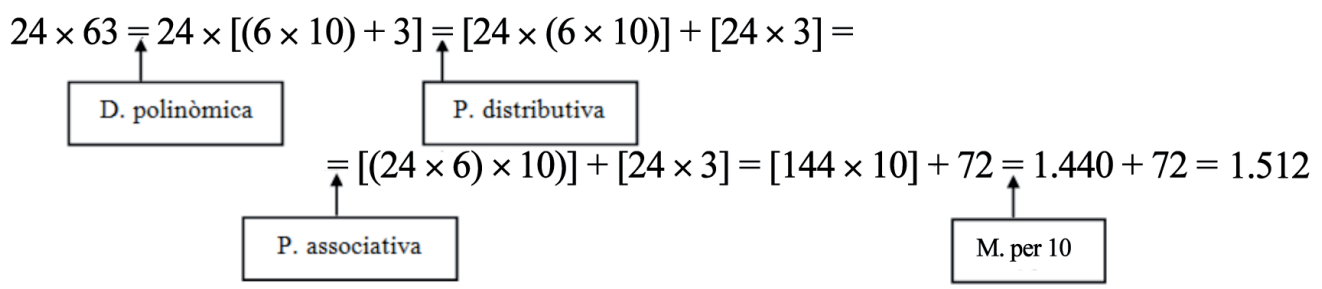

S'han de fer més exemples de multiplicacions que siguen solució de situacions problemàtiques reflexionant amb l'alumnat sobre la col·locació dels nombres. Han d'observar que el resultat parcial de multiplicar per la desena sempre presenta un zero en la xifra de les unitats, i a partir d'aquest moment poden deixar d'escriure'l, 
i arribar d'aquesta manera a l'expressió habitual de l'algorisme, que representem a continuació amb el mateix exemple:

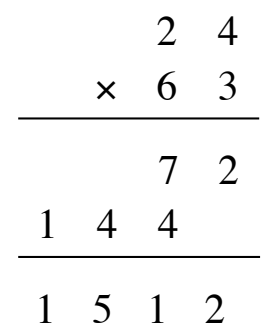

Per a tornar al context de treball, respondrem a la pregunta de la situació problemàtica de partida: «Si els 24 xiquets i xiquetes de $4 \mathrm{t}$ de Primària, com una activitat d'educació física hem anat fins ara 63 vegades a la piscina en tots els anys de col·legi, hem comprat 1512 entrades».

Es faran més exemples de multiplicació associades a la resolució de situacions problemàtiques. En la reflexió amb l'alumnat sobre la relació del multiplicand i multiplicador amb el producte o resultat, els ajudarem a què arriben a una conclusió semblant a: «per multiplicar un nombre per un altre de dues xifres, es multiplica el primer per la xifra de les unitats del segon i posteriorment per la de les desenes d'aquest. Obtenim així els dos productes parcials, que s'hauran de situar correctament per sumar-los i arribar al producte final». Han descobert com funciona aquest procediment que anomenem algorisme estàndard de multiplicar per un nombre de dues xifres.

L'objectiu final serà que els alumnes utilitzen l'expressió estàndard de l'algorisme com la manera habitual de resoldre les multiplicacions de les situacions problemàtiques que se'ls presenten.

Una vegada assolit l'algorisme de la multiplicació per dues xifres, s'aniran introduint situacions en les quals es vaja augmentant el nombre de xifres tant del multiplicand com del multiplicador, procedint de forma semblant al que s'ha vist fins ara. Així, per al cas de la multiplicació de $574 \times 263$, per exemple, haurem d'ensenyar-los primer a multiplicar per centenes completes, $574 \times 200$, que es farà de manera anàloga a la multiplicació per desenes completes, i continuen amb el procediment anterior fins a arribar al resultat final.

\section{C.10. Desenvolupar l'agilitat mental en el càlcul de la multiplicació}

De manera espontània i de forma semblant a les operacions anteriors, en veu alta, dins d'un joc, en diferents situacions..., i sempre amb un nivell de dificultat inferior al treballat a classe en l'àmbit simbòlic, utilitzarem la multiplicació per exercitar el càlcul mental. Ha de quedar clara la necessitat i la conveniència de memoritzar la taula de multiplicar, però només com una eina de rapidesa, per economitzar esforços i mai com a finalitat en si mateixa. Ha de servir per resoldre situacions de la vida real recreades a classe. 
Caldrà insistir també en l'automatització de les multiplicacions per la unitat seguida de zeros i en la utilitat d'aquestes per reforçar el funcionament del sistema de numeració decimal i la formació d'uns ordres d'unitats a partir d'altres.

Al final del 1r cicle de Primària, es treballarà la taula de la multiplicació i multiplicacions de dues xifres del multiplicand, que en duplicar, triplicar o quadruplicar puguen trobar fàcilment el resultat perquè tinguen relació amb les descomposicions additives treballades en la capacitat A.8. Per exemple, el doble, triple, etc., de 15 , de 25 o de 30 , és una conseqüència immediata d'algunes descomposicions additives de 45, 100 i 60, entre d'altres.

No oblidarem les estratègies personals que cada alumne ha creat tant en l'addició com en la subtracció per aplicar-les també a la multiplicació, demanant que ens verbalitzen allò que fan en calcular mentalment per assegurar-nos que estan pensant correctament. De la mateixa manera els insistirem en les ajudes que les propietats commutativa, associativa i distributiva els poden oferir per realitzar els càlculs mentals.

A mesura que es va dominant aquest càlcul mental i el de les altres operacions, es pot combinar gradualment la multiplicació amb elles per tal de fer un treball conjunt.

A més a més, es disposa de material, que amb l'ajuda del joc, facilita la memorització de la taula de multiplicar.

\section{Dòmino de la multiplicació (fabricat per Taskmaster Ltd.)}

És un material per treballar la multiplicació. Es reparteixen fitxes del joc, i per torns han d'associar el resultat amb la multiplicació corresponent, si és que tenen la fitxa adequada (figura 67).

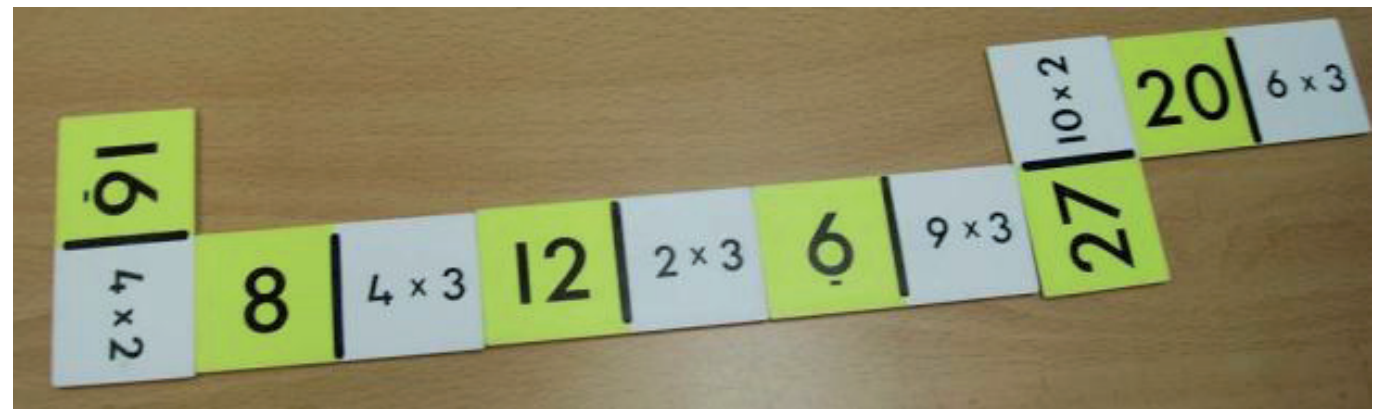

Figura 67. Imatge d'una seqüència de joc amb el Dòmino de la multiplicació

Aquest material presenta quatre tipus de fitxes. Unes, amb la part del resultat pintada de color groc, tenen multiplicacions per 2 i per 3. D'altres, amb la part del resultat pintada de color roig, tenen multiplicacions per 4 i per 5 . D'altres, amb la part del resultat pintada de color verd, tenen multiplicacions per 6 i per 7. Finalment, d'altres, amb la part del resultat pintada de color blau, tenen multiplicacions per 8 i per 9 . El joc es pot plantejar separadament o combinant les quatre tipus de fitxes. 
D'una manera molt semblant al material anterior, però amb un format triangular, a la figura 68 es mostra una tirada:

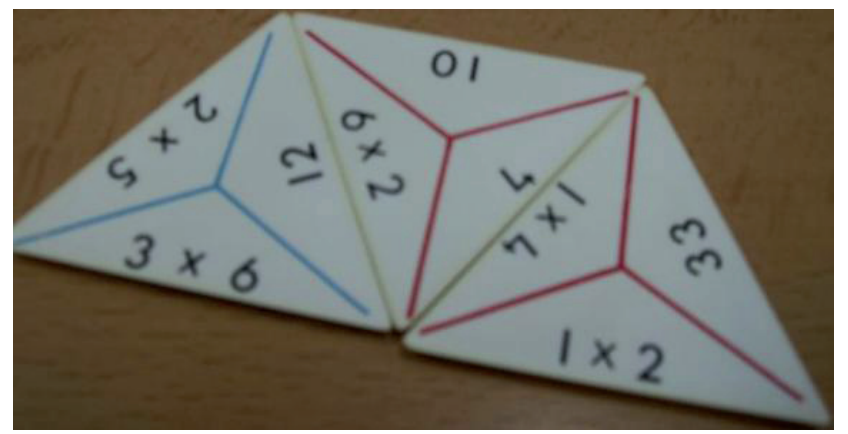

Figura 68. Imatge d'una seqüència de joc amb el Triòmino de la multiplicació

Aquest material presenta tres tipus de fitxes. Unes, amb marques de separació de color roig, tenen multiplicacions per 2, 3 i 4. D'altres, amb marques de separació de color blau, tenen multiplicacions per 5, 6 i 7. Finalment, d'altres, amb marques de separació de color verd, tenen multiplicacions per 8, 9 i 10. El joc es pot plantejar separadament o combinant els tres tipus de fitxes.

Com que els dos materials anteriors són de fabricació anglesa, incorporen multiplicacions que contenen com a factors 11 i 12 .

\section{Penkamino (fabricat per Royal Games)}

Introdueix un poc més de dificultat i per això es presenta en tercer lloc. Els factors es troben als braços de les creus i els resultats als vèrtexs dels quadrat. Se'ls reparteixen fitxes de les dues maneres, i per torns, han d'associar les multiplicacions amb els resultats (figura 69).

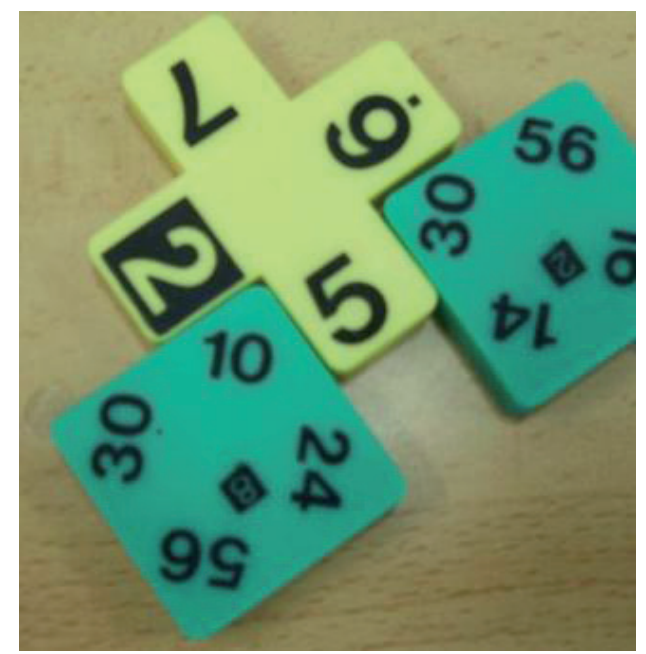

Figura 69. Imatge d'una seqüència de joc amb el Penkamino 
Malgrat que el format sembla més infantil, és el material que requereix més agilitat amb la multiplicació, perquè han de col·locar el nombre a sobre de l'operació al mateix temps que escolten el qui canta el resultat i, a més a més, no enganyar-se (figura 70).

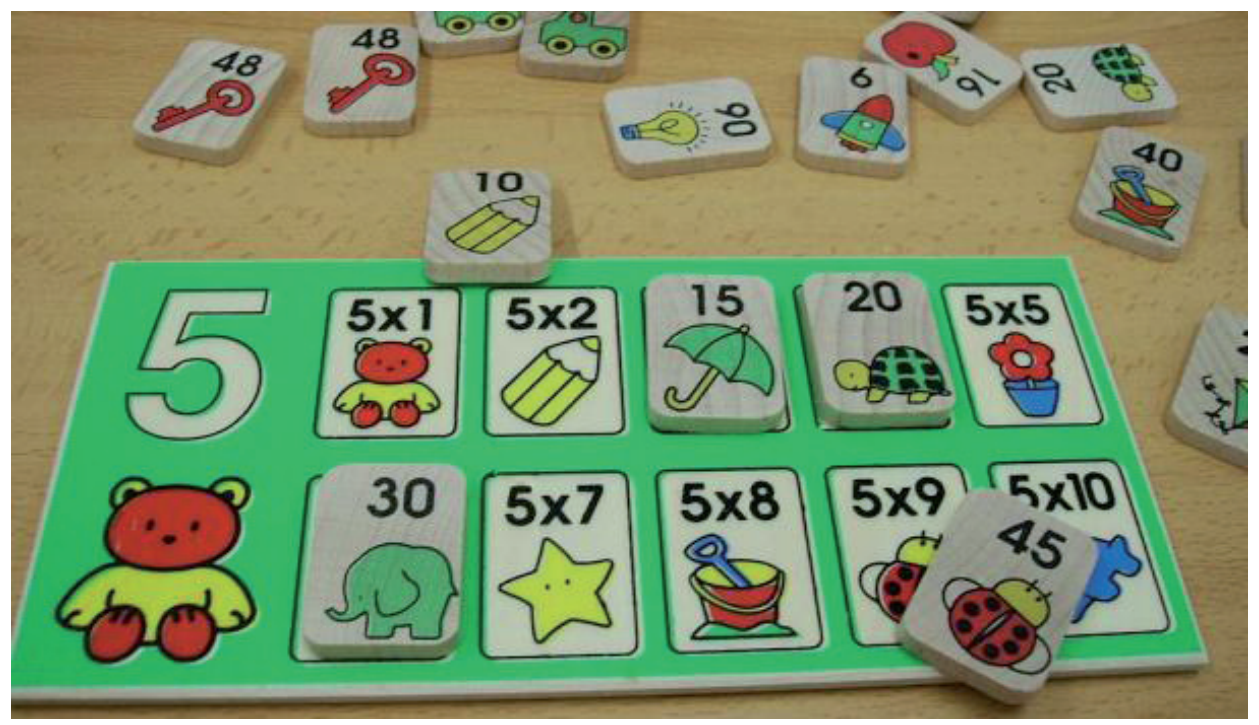

Figura 70. Imatge d'una seqüència de joc amb el Bingo de la multiplicació

\section{C.11. Resoldre i inventar situacions problemàtiques relacionades amb la multiplicació}

Com ja s'ha esmentat, és en situacions reals on cobra especial sentit el treball fet amb aquesta operació, perquè realment és la realitat la que origina interrogants, la resposta dels quals passarà per saber, en aquest cas, resoldre multiplicacions.

Com al cas de l'addició i la subtracció, encara que la resolució i invenció de problemes apareix com la quarta fase per treballar les operacions, també ara ens trobem en ella des del principi, perquè presentem les multiplicacions de manera contextualitzada, a partir de situacions reals que han de resoldre's i que, igualment, estaran relacionades amb qualsevol bloc de continguts matemàtics.

Continuarem treballant la resolució de problemes a partir de les quatre fases de Polya i de la reflexió amb l'alumnat sobre la seua importància, desenvolupament i utilitat.

Com s'ha comentat en les capacitats A.9 i B.9 i amb les mateixes consideracions, aprofitarem els errors per generar nous aprenentatges i continuarem amb el treball d'estimació dels resultats de les situacions problemàtiques.

Iniciarem el treball en $2 \mathrm{n}$ de Primària, amb situacions problemàtiques que necessiten ser resoltes amb una multiplicació. És molt important que, en els primers moments, prestem atenció al pas entre una addició de sumands iguals i una multiplicació on el multiplicador indique el nombre de sumands que s'estan operant. 
Quan ja reconeguen la multiplicació com l'operació que serveix per resoldre qualsevol d'aquestes situacions, plantejarem problemes relacionats amb elles parant compte que les multiplicacions apareguen de manera aïllada.

Més endavant treballarem problemes que necessiten dues multiplicacions per a ser resolts. Els problemes esmentats fins ara seran de nombres de dues o tres xifres, per passar a 3r de Primària a situacions amb nombres qualssevol.

També i a finals del $1 \mathrm{r}$ cicle i inicis del 2 n, es poden proposar problemes que necessiten per a ser resolts la combinació d'una subtracció, una addició i una multiplicació.

En referència als enunciats de les situacions problemàtiques seguirem els mateixos passos que per a l'addició i la subtracció (capacitats A.9 i B.9) però haurem de fer una consideració afegida. Es tracta de la necessitat que dins dels enunciats clars, ordenats, complets, sense errors... tinguem cura, al principi, de fer aparèixer les dades de manera ordenada d'acord amb el seu paper en la multiplicació que han de realitzar, és a dir, que el primer nombre siga el multiplicand i el segon el multiplicador (si cada alumne necessita 8 fulls per a una activitat $i$ hi ha 5 xiquets oxiquets per grup, quants fulls haurem de preparar per cada grup?). Avançat el cicle no serà necessari respectar aquest ordre (si som 5 alumnes per grup a classe $i$ necessitem 8 fulls per a una activitat, quants fulls haurem de preparar per cada grup?).

En aquest cas, l'aparició de problemes amb enunciats confusos, incomplets, amb dades que falten, amb dades que sobren... haurà de ser un poc més retardada que en el treball amb l'addició i la subtracció.

Desenvoluparem també tasques d'invenció de problemes relacionats amb la multiplicació amb les mateixes orientacions donades per a l'addició i la subtracció (capacitats A.9 i B.9), tant referides a l'oferiment d'ajudes a l'alumnat com a la necessitat d'intercanviar entre els xiquets $i$ les xiquetes els enunciats inventats. La diferència en aquest cas serà el treball inicial de diferenciació entre l'addició de sumands repetits i la multiplicació on el multiplicand siga el sumand i el multiplicador el nombre de sumands. I, sobretot, els avantatges que aquesta darrera operació ofereix enfront de la primera.

En els cicles posteriors es continuarà amb les tasques de resolució i invenció de situacions problemàtiques relacionades amb la multiplicació, en les quals aquesta operació es combinarà amb les altres tres a mesura que les vagen dominant.

A mesura que avança el $2 \mathrm{n}$ cicle cal completar la informació sobre la multiplicació presentant als alumnes situacions reals que es resolguen multiplicant, i que intuïtivament no corresponguen a una expressió numèrica d'addicions de sumands iguals. Seran situacions en les quals la multiplicació sorgeix com l'operació que ens permet calcular el cardinal del producte cartesià de dos conjunts que tenen com a cardinals els factors de la multiplicació. L'expressió formal del 
producte cartesià de dos conjunts A i B és $A \times B=\{(a, b) / a \in A \wedge b \in B\}$, i si $m=\operatorname{card}(A), n=\operatorname{card}(B)$ es defineix: $m \times n=\operatorname{card}(A \times B)$.

Podem veure com es desenvolupen aquestes situacions a l'aula amb l'exemple següent: «Per fer un berenar d'aniversari a l'aula hem comprat 5 tipus diferents d'entrepans i 3 tipus de beguda. De quantes maneres diferents pot berenar cada xiquet, triant un entrepà i una beguda?».

Per resoldre aquesta situació, els xiquets formaran totes les parelles possibles amb un tipus d'entrepà i una classe de beguda i, després de comprovar que el nombre de possibilitats és 15 , haurien de respondre a la nostra pregunta sobre quina és l'operació que resoldrà numèricament situacions d'aquest tipus sense que siga necessari formar totes les parelles. Evidentment, la resposta ha de ser la multiplicació. A partir d'aquest moment i de la realització d'exemples semblants, utilitzaran la multiplicació per resoldre qualsevol situació que tinga aquest tipus de plantejament.

\section{C.12. Adquirir la noció de potència com a producte de factors iguals. Identificar la base i l'exponent d'una potència}

La potenciació de Nombres Naturals és una nova manera d'anomenar la multiplicació quan es produeix una situació concreta. Aquesta situació s'origina quan tots els factors de la multiplicació coincideixen. Per exemple: «Si tenim dos mobles amb dos calaixos i en cadascun dos joguets de dues peces cadascun, quantes peces hi ha?». Resulta evident expressar la resposta amb $2 \times 2 \times 2 \times 2=16$, però de la mateixa forma que es va arribar a una nova manera d'expressar una addició de sumands iguals quan es va introduir la multiplicació, ara hauríem d'aconseguir que s'arribara a una altra forma d'expressar aquesta situació. La nova operació, anomenada potenciació, transforma la multiplicació representant-la de la següent manera: $2 \times 2 \times 2 \times 2=2^{4}$. És més econòmica d'escriptura i més intuïtiva, perquè no cal comptar quants factors hi ha. Però, és clar, per simplificar en un futur els càlculs, cal introduir aquesta nova notació, i això és una dificultat afegida a curt termini. S’introduirà en 3 r cicle de Primària.

Cal posar nom als elements d'aquesta nova expressió, a més a més de llegir-la correctament. En l'exemple anterior, el 2 s'anomena base, el 4 exponent, i el 16 potència, i es llig «dos elevat a quatre o dos a la quarta».

Per tal d'agilitzar els càlculs amb aquesta operació i amb l'objectiu de preparar el camí a l'àlgebra, en l'últim curs del cicle es treballaran les següents propietats de la potenciació:

1. Multiplicació de potències de la mateixa base

Treballarem a partir d'una situació problemàtica, per exemple: «Un edifici d'habitatges té 3 escales, en cadascuna hi ha 3 nivells i en cada nivell, 3 habitatges. 
Quants habitatges hi ha? Cada habitatge disposa de 3 habitacions, cadascuna de les quals té 3 endolls. Quants endolls hi ha per habitatge? Quants endolls necessitarà el promotor de l'edifici?».

L'operació necessària, per tal de respondre a la primera pregunta, és $3^{3}$. Per respondre a la segona, $3^{2}$. I per respondre a la tercera, $3^{3} \times 3^{2}=27 \times 9=243$.

En aquest moment se'ls planteja la situació de la manera següent: «Un edifici d'habitatges té 3 escales, en cadascun hi ha 3 nivells, en cada nivell, 3 habitatges, cada habitatge té 3 habitacions, cadascuna de les quals disposa de 3 endolls. Quants endolls necessitarà el promotor de l'edifici?».

Després de respondre $3^{5}$, i arribar al $3^{5}=243$, observem els dos procediments que els han conduït a resultats iguals, i els expressem numèricament: $3^{3} \times 3^{2}=243=3^{5}$, i fixant-se en les bases i els exponents els ajudarem a obtenir la conclusió següent: $3^{3} \times 3^{2}=3^{3+2}=3^{5}$.

Després de comprovar aquest fet amb diversos exemples numèrics, la propietat es pot enunciar: «Per tal de multiplicar potències de la mateixa base, es deixa la base i se sumen els exponents». En llenguatge matemàtic: $\forall b, m, n \in \mathrm{N}: b^{m} \times b^{n}=b^{m+n}$.

\section{Divisió de potències de la mateixa base}

Treballarem de nou a partir d'una situació problemàtica, per exemple: «En cadascuna de les tres classes d'un col-legi rural es disposa de tres armaris amb tres caixes en cadascun. En cada caixa hi ha tres bosses amb tres carpetes cadascuna. Quantes carpetes hi ha? Fem tres grups de tres alumnes per distribuir-les entre els companys. Quants alumnes van a distribuir-les? Si repartim les carpetes entre aquests alumnes, quantes en corresponen a cada alumne?».

L'operació necessària, per tal de respondre a la primera pregunta és $3^{5}$. Per respondre a la segona, $3^{2}$. I per respondre a la tercera $\frac{3^{5}}{3^{2}}=\frac{243}{9}=27$.

En aquest moment, i per tal de trobar una relació directa entre les potències inicials i el resultat, se'ls demana que expressen aquest com una potència de 3 i obtindran $27=3^{3}$, amb la qual cosa s'arribarà a $\frac{3^{5}}{3^{2}}=27=3^{3}$. Se'ls preguntarà per la relació que hi ha entre els exponents inicials dels termes de la divisió i el del resultat, i es conclourà que: $\frac{3^{5}}{3^{2}}=3^{3}=3^{5-2}$.

Després de comprovar aquest fet amb diverses situacions problemàtiques i exemples numèrics, la propietat es pot enunciar: «Per tal de dividir potències de la mateixa base, es deixa la base i es resten els exponents». En llenguatge matemàtic: $\forall b, m, n \in \mathrm{N}: \frac{b^{m}}{b^{n}}=b^{m-n}$. 


\section{Potència d'una potència}

Treballarem també a partir d'una situació problemàtica (cal dir que serà més complicat trobar-la que en les altres propietats), per exemple: «En una ciutat hi ha quatre clubs de futbol, cada club té equips de quatre categories, i en cada categoria quatre equips. Quants equips de futbol hi ha en aquesta ciutat? S'organitza un torneig futbolístic amb una altra ciutat, que té el mateix nombre de clubs, categories i equips que la primera. De quantes maneres diferents es poden organitzar partits amb un equip de cada ciutat, si poden enfrontar-se els de qualsevol categoria?».

L'operació necessària, per respondre a la primera pregunta és $4^{3}$. La segona ciutat té el mateix nombre d'equips; per tant, $4^{3}$. Per respondre a la segona pregunta cal multiplicar tots els equips de la primera ciutat pels de la segona; així, $4^{3} \times 4^{3}=64 \times 64=4096$. A continuació se'ls demana que expressen el resultat com una potència de base 4 , i han d'arribar a $4^{6}$.

Per definició de potència, l'expressió inicial $4^{3} \times 4^{3}$ poden expressar-la com $\left(4^{3}\right)^{2}$. Per tant, $\left(4^{3}\right)^{2}=4^{6}$. Comparem els dos membres d'aquesta igualtat i els demanem que relacionen els seus exponents, amb la qual cosa arribem a $\left(4^{3}\right)^{2}=4^{6}=4^{3 \times 2}$.

Després de comprovar aquest fet amb diverses situacions problemàtiques i exemples numèrics, la propietat es pot enunciar: «Per tal de calcular la potència d'una altra potència, es deixa la base $\mathrm{i}$ es multipliquen els exponents». En llenguatge matemàtic: $\forall b, m, n \in \mathrm{N}:\left(b^{m}\right)^{n}=b^{m \times n}$.

Nota: Casos particulars

1. A partir del coneixement de la potenciació, es pot expressar la descomposició d'un nombre en la seua forma polinòmica correcta: $3.654=3 \times 10^{3}+6 \times 10^{2}+5 \times 10+4$.

2. Qualsevol potència d'exponent 1 dóna com a resultat la base, ja que hi ha un únic factor que és la base.

3. Qualsevol potència d'exponent 0 dóna com a resultat 1 si la base és distinta de zero.

L'explicació que els podríem donar es dedueix de la segona propietat de la potenciació: com que saben que $\frac{3}{3}=1$ i $\frac{3}{3}=3^{1-1}=3^{0}$, es conclou $3^{0}=1$.

\section{Divisió}

De la mateixa manera que el resultat de la subtracció es pot obtenir buscant el sumand que faltava a una addició, la multiplicació es dedueix d'una addició de sumands iguals, i la potenciació d'una multiplicació amb un factor que es repeteix, la nova operació que es presenta, la divisió, també deriva d'una operació anterior. A més, 
connecta directament amb algunes de les accions intuïtives que abans d'entrar a l'escola els xiquets i xiquetes ja han realitzat, les de repartir elements o formar-hi grups.

La definició de la divisió exacta que es deriva de la teoria de conjunts, la presenta com l'operació que ens permet calcular el quocient de dos nombres, entenent el quocient com el cardinal de qualsevol dels subconjunts que resulten de la partició d'un conjunt en un nombre determinat de subconjunts equipotents, o bé l'operació que ens permet calcular el quocient de dos nombres, entenent el quocient com el nombre de subconjunts equipotents d'un determinat cardinal, que s'obtenen de la partició d'un conjunt.

Aquesta definició a partir de subconjunts equipotents ens fa pensar immediatament en la multiplicació treballada amb anterioritat i entendre la divisió exacta com l'operació que busca el factor que li falta a una multiplicació de la qual es coneix el resultat i l'altre factor.

\section{D.1. Construir la idea de divisió exacta utilitzant particions en les quals totes les parts siguen equipotents $i$ expressant els cardinals que hi intervinguen. \\ Simbolitzar aquestes particions utilitzant els signes $« \mathrm{x} » i \ll=»$}

En aquesta capacitat desenvolupem el treball corresponent a la primera de les fases d'E-A de la divisió, que es realitza en el 3r curs de l'etapa, quan ja tenen prou avançat el coneixement de la multiplicació.

Com es dedueix de la definició, aquesta operació es relaciona amb dos tipus de situacions, d'agrupament i de repartiment. Partirem, per tant, d'activitats pràctiques i manipulatives en les quals els xiquets i les xiquetes es troben en la necessitat d'agrupar o repartir una quantitat inicial d'elements en conjunts equipotents i disjunts.

Podem començar amb una situació d'agrupament, com per exemple: «Si tenim 8 caramels i hem de donar-ne 2 a cada xiquet, per a quants xiquets n'hi ha?». De manera intuïtiva, sense necessitat de massa explicació, el que faran és agafar els 8 caramels i agrupar-los de 2 en 2 fins que s'esgoten, formant 4 conjunts equipotents.

Quan els proposem que ens expliquen el que ha passat amb els caramels utilitzant els nombres que han intervingut en la situació, és imprescindible que siguen conscients que hi havia un conjunt inicial de 8 caramels i ara n'hi ha 4 subconjunts de 2. D'aquesta manera connectarem directament amb la multiplicació, perquè 2 caramels de cada xiquet per 4 xiquets, són 8 caramels. Aleshores, queda la porta oberta per dir que el que s'està buscant és un factor d'aquella multiplicació que es desconeix, $\mathrm{i}$ ens trobem amb la representació següent: $2 \times ? ?=8$.

Amb la intenció d'apropar a la nova operació les frases que utilitzen per explicar el que ha passat amb els caramels, els ajudarem en l'evolució verbal modificant 
l'enunciat «si 8 caramels els agrupem de 2 en 2 , en tenim per a 4 xiquets», fins a arribar a «8 agrupats de 2 en 2 , dóna 4 grups» i completar així la multiplicació anterior amb el 4 que faltava: $2 \times 4=8$.

Fins ara no han necessitat una nova operació per respondre a la pregunta inicial, ho han fet utilitzant la multiplicació incompleta. Però aquesta és una forma estranya de treballar la multiplicació i, a més, quan els nombres siguen més grans i no es puguen manipular els elements, ens farà falta una nova manera numèrica de resoldre-ho. Aquesta manera de resoldre numèricament les situacions l'anomenarem divisió i podrem canviar les expressions anteriors per «si dividim 8 entre 2 dóna 4 » o bé « 8 dividit entre 2 són $4 »$.

Per completar la iniciació a la divisió haurem de treballar també amb situacions de repartiment. Podem fer-ho amb l'exemple «Hi ha 8 caramels per repartir-los en parts de la mateixa quantitat entre 2 xiquets. Quants n'hi ha per a cada xiquet?». En aquesta ocasió el que faran és agafar els 8 caramels i un a un repartir-los entre els xiquets fins que no en queden.

Quan expliquen ara el que ha passat amb els caramels utilitzant els nombres que han intervingut en la situació, hauran de ser conscients que hi havia un conjunt inicial de 8 caramels i ara n'hi ha 2 subconjunts de 4 . Novament connectaran amb la multiplicació, perquè 4 caramels de cada xiquet per 2 xiquets són 8 caramels. Una altra vegada queda la porta oberta per dir que el que s'està buscant és un factor que desconeixen d'aquesta multiplicació, i ens trobem amb la representació següent: ?? $\times 2=8$.

Amb la intenció d'apropar les frases que utilitzen cap a la nova operació, els ajudarem a modificar l'enunciat "si repartim 8 caramels entre 2 xiquets, toquen a 4 cadascun», fins a arribar a «8 repartits entre 2 , dóna $4 »$, i completar així la multiplicació anterior amb el 4 que faltava: $4 \times 2=8$.

En aquest moment connectaran amb la idea de divisió introduïda abans i utilitzaran de nou les expressions «si dividim 8 entre 2 fan 4 » o bé « 8 dividit entre 2 són 4 ».

Es repetiran situacions problemàtiques dels dos tipus anteriors fins que aquestes idees estiguen assolides.

El final de la fase serà demanar als xiquets i xiquetes que siguen ells qui troben o reconeguen situacions de la seua vida personal que estiguen relacionades amb l'operació (plats, entrepans...).

\section{D.2. Canviar simbolitzacions de multiplicacions incompletes per d'altres que usen els signes «:» $i$ «=». Identificar $i$ utilitzar correctament els termes $i$ signes de la divisió exacta}

Continuant en el 3r curs, una vegada realitzades les accions anteriors i coneguda la paraula divisió, és el moment de passar a la segona fase d'e-A de l'operació, 
introduint els signes «:» $\mathrm{i}$ «=». Aleshores, les multiplicacions incompletes associades a l'enunciat verbal «8 dividit entre 2 fan $4 », 2 \times ? ?=8$ i ?? $\times 2=8$, es canvien per l'expressió numèrica de la divisió $« 8: 2=4 »$.

Introduirem també els noms propis dels termes i el resultat de la divisió: el 8 s'anomenarà dividend, el 2 divisor i el 4 quocient. El signe «:» es llegeix dividit per, i el signe «=», igual (que ja el coneixien).

Cal notar que el dividend sempre és el nombre d'elements a agrupar o repartir. El divisor pot ser el nombre d'elements de cada subconjunt equipotent en el primer cas o el nombre de subconjunts equipotents a formar en el segon, i el quocient serà, respectivament, el nombre de subconjunts equipotents que es formen o el cardinal dels subconjunts equipotents formats.

Com que l'alumnat ja coneix els termes i signes de la resta d'operacions, haurem de comprovar que els identifica i els diferencia correctament dels que acabem d'introduir.

D.3. Construir la idea de divisió entera utilitzant particions en les quals totes les parts menys una siguen equipotents $i$ expressant els cardinals que hi intervinguen. Simbolitzar aquestes particions usant els signes «+», « $\mathrm{x} » i \ll=»$

Després d'introduir el significat de l'operació amb els exemples anteriors que generen divisions exactes i per tal d'estendre l'operació a qualsevol parell de nombres naturals treballarem, seguint un procediment anàleg, amb situacions del tipus «Hi ha 9 caramels per donar-ne 2 a cada xiqueta. Per a quantes xiquetes n'hi ha?» o bé «Hi ha 9 caramels per repartir-los en parts de la mateixa quantitat entre 2 xiquetes. Quants n'hi ha per a cada xiqueta?».

En aquests casos arribaran a agrupaments o repartiments en els quals una de les parts no és equipotent a les altres i donaran lloc a divisions enteres. Les expressions dels casos anteriors $2 \times ? ?=8 \mathrm{i} ? ? \times 2=8$ no serveixen per a aquests. Caldrà reformular-les i així apareixerà un nou terme que representa el cardinal de la part no equipotent amb les altres $(2 \times ? ?)+1=9 \mathrm{i}(? ? \times 2)+1=9$.

En les explicacions de l'alumnat per dir el que ha passat en el primer exemple amb els caramels, els ajudarem en l'evolució verbal i trobarem expressions com:

- Si 9 caramels els agrupem de 2 en 2, tenim per a 4 xiquetes, i en sobra 1.

- 9 agrupats en grups de 2, dóna 4 grups i en sobra 1.

- Si dividim 9 entre 2 dóna 4 i en sobra 1.

- 9 dividit entre 2 fan 4 i en sobra 1.

I per al segon:

- Si 9 caramels els repartim en parts de la mateixa quantitat entre 2 xiquetes, toquen a 4 cadascuna i en sobra 1. 
- 9 repartit en parts de la mateixa quantitat entre 2 dóna 4 i en sobra 1.

- Si dividim 9 entre 2 dóna 4 i en sobra 1.

- 9 dividit entre 2 són 4 i en sobra 1.

Es repetirà també el treball amb situacions problemàtiques d'aquests tipus, per aprofundir en la nova consideració de la divisió i es demanarà als xiquets i xiquetes que siguen ells qui troben o reconeguen situacions de la seua vida personal que estiguen relacionades amb l'operació.

A partir d'aquest moment caldrà utilitzar el vocabulari associat als dos tipus de divisió que hem introduiit. Així hauran de reconèixer les divisions exactes com aquelles en les quals, després de fer els agrupaments o el repartiment, no sobra cap element $\mathrm{i}$ les divisions enteres com les que sí que en sobra.

\section{D.4. Simbolitzar divisions enteres usant la representació habitual. Identificar $i$ utilitzar correctament els termes $i$ signes de la divisió entera}

Continuant en el 3r curs, una vegada realitzades les accions anteriors, és el moment de passar en aquestes altres divisions a la segona fase d'E-A de l'operació, introduint els termes i els signes corresponents. En el cas de la divisió entera, no es pot utilitzar l'expressió $9: 2=4$, perquè no és certa. Aleshores, es fa necessari usar una disposició diferent dels termes per representar aquesta nova situació:

$9 \mid \underline{2}$ en la qual la «caixa» 14 ha substituilt els dos punts, i com que apareix

un terme nou, l'1, s'introduirà el nom i el significat d'aquest: residu, que representa el nombre d'elements que queden sense repartir. La resta de nombres de la divisió reben el mateix nom que en el cas de la divisió exacta i tenen el mateix significat.

\section{D.5. Realitzar divisions de nombres utilitzant particions de conjunts en parts equipotents}

És important que després d'haver introduït l'expressió simbòlica de l'operació, aquesta no es desconnecte de les accions amb les quals es relaciona. Per això, també en el 3r curs i en moments posteriors al treball de les capacitats anteriors, caldrà mostrar-los expressions simbòliques de divisions que hauran de calcular mitjançant particions de conjunts en parts equipotents, bé mitjançant agrupaments o bé per repartiment.

Aquest és un treball invers al realitzat en les capacitats anteriors, en les quals l'alumnat avançava des de les accions amb els objectes fins a les expressions numèriques de les situacions.

Si els xiquets i les xiquetes són capaços de trobar els resultats de les divisions propostes sense recórrer als objectes, poden resoldre-les numèricament d'aquesta 
manera, però haurem de reflexionar-hi sobre el significat de l'operació i sobre la seua relació inequívoca amb situacions en les quals es parteix un conjunt inicial en subconjunts equipotents.

En la 3a fase d'E-A de la divisió treballarem el seu algorisme, que envolta una sèrie de dificultats que no estaven presents en les anteriors operacions. Aquestes complicacions s'han de tenir en compte per poder resoldre els possibles conflictes que es presenten amb l'alumnat, i són les següents:

- És un algorisme que avança per les xifres del dividend d'esquerra a dreta, amb la qual cosa trenca l'ordre establert en les operacions anteriors.

- Es busca un resultat i se'n troben dos, quocient i residu.

- Hi ha restriccions: el residu (r) ha de ser menor que el divisor (d), i el dividend (D), major o igual que el divisor. $S$ 'ha de complir $\mathrm{D} \geq \mathrm{d}>\mathrm{r}$.

- Necessita altres operacions per desenvolupar el seu algorisme. En particular de la subtracció i de la multiplicació.

- No és automàtic, necessita passos:

- Separar en el dividend, «quantes xifres cal separar?».

- Estimar una xifra per al quocient, «quant li cabrà?».

- La xifra estimada, multiplicada pel divisor, ha de donar un resultat que no se'n passe de la quantitat separada en el dividend, «però que estiga com més pròxim millor».

- Comprovar el càlcul anterior i refer, si ens hem enganyat, els càlculs.

Tot això fa que l'algorisme de la divisió siga el més complicat de tots els algorismes de les operacions aritmètiques bàsiques.

\section{D.6. Descobrir l'algorisme de la divisió exacta i entera per una xifra i utilitzar-lo per realitzar divisions exactes $i$ enteres en les quals augmente progressivament el nombre de xifres del dividend}

En aquesta 3a fase d'E-A de la divisió i quan en el treball a classe es presente una situació problemàtica que implique dividir dos nombres el quocient dels quals no es deduïsca directament de la taula de multiplicar, serà el moment d'introduir l'algorisme de la divisió d'un nombre de dues xifres, per un altre d'una.

De manera anàloga a les altres operacions, es proposa la primera part d'una seqüència didàctica ordenada per nivells de dificultat segons la qual s'haurien d'introduir els algorismes de l'operació en el 2n i 3r cicle d'Educació Primària.

Començarem per divisions exactes i enteres d'un nombre de diverses xifres per un nombre d'una sola xifra, recorrent els trams següents:

1. Dues xifres en el dividend i dues en el quocient, amb residus parcials iguals a zero, per exemple, $64: 2,64: 3$. 
2. Dues xifres en el dividend i dues en el quocient, amb residus parcials diferents de zero, per exemple, $64: 4,74: 3$.

3. Tres xifres en el dividend $i$ tres en el quocient (amb residus parcials iguals o diferents de zero), per exemple, $642: 2,643: 2,652: 4,653: 4$.

4. Tres xifres en el dividend i dues en el quocient (amb residus parcials iguals o diferents de zero), per exemple, $142: 2,143: 2,152: 4,153: 4$.

5. Qualsevol nombre de xifres en el dividend.

De la mateixa manera que en la resta d'operacions, treballarem la construcció d'aquest algorisme, per a la seua comprensió i posterior automatització, amb l'ajuda dels materials didàctics que ja coneixen (com són els BM i els àbacs) i la transcripció escrita de les accions que fan.

Suposem que es presenta a classe una situació problemàtica com la següent: «Els alumnes de $3 \mathrm{r}$ de Primària d'un col·legi marxen d'excursió. Han d'agafar dos autobusos i, per tant, s'han de repartir en dos grups de la mateixa quantitat. Quants pujaran a cada autobús si són 64 alumnes en total?».

Es comentarà amb ells i elles com trobar la resposta i arribarem a la conclusió que cal resoldre la divisió de 64 entre 2, però no la saben calcular numèricament encara, perquè no correspon a cap resultat de multiplicació de la taula, que sí que coneixen. Abans de continuar amb la manipulació dels materials, es comenta amb l'alumnat la necessitat d'expressar per escrit el que ocorre numèricament per tenir la memòria del procés que es portarà i del resultat final:

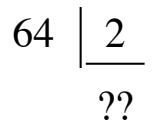

Després que presenten les seues propostes de resolució de l'operació i en la recerca de la manera comuna de fer-ho, introduirem l'algorisme estàndard corresponent.

Fent ús dels materials didàctics, al cas dels BM, representaran el 64 i després el separaran en dos subconjunts que tinguen el mateix nombre d'elements. Obtindran en cada subconjunt tres reglets i dos cubs, és a dir, 32, que serà el quocient de la divisió. Què ha passat? Possiblement han repartit en primer lloc el nombre de reglets i, en segon lloc, el de cubs i, si no és així, intentarem guiar-los perquè facen el repartiment del material començant per les unitats d'ordre superior, ja que els ajudarà en la posterior expressió numèrica de l'operació. Estan construint el que serà l'algorisme de la divisió per una xifra, començant pels reglets (desenes) i continuant pels cubs (unitats), és a dir, d'esquerra a dreta (figura 71). 


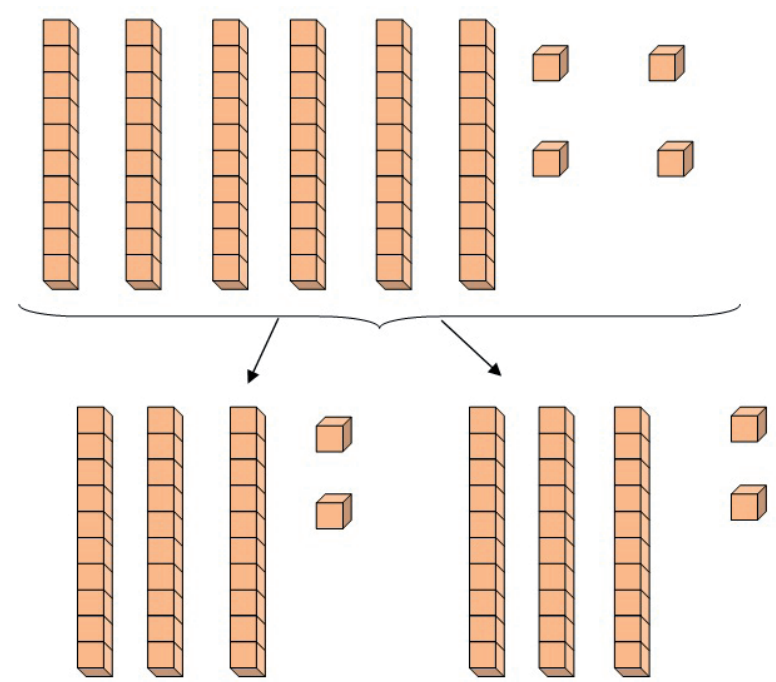

Figura 71. Representació amb BM de la divisió de 64 entre 2

Al cas dels àbacs, representaran el dividend en un àbac i caldrà repartir-lo en dues parts equipotents. Necessiten dos àbacs més per col-locar les boles que lleven de l'àbac inicial. Per repartir les boles, i amb les mateixes consideracions que en el cas anterior, començaran per la vareta de les desenes fins que no en quede cap; posteriorment repartiran les unitats. En cadascun dels dos àbacs queda representat el quocient, que és el 32.

De manera simultània a la manipulació amb els materials i la corresponent verbalització, continuem amb l'expressió numèrica que havien escrit en un primer moment:

$$
64 \mid 2
$$

El fet de separar els reglets o començar a repartir per la vareta de les desenes s'indica posant una coma entre el 6 i el 4 o una marca damunt del 6 (encara que, per no complicar el desenvolupament, es tria la primera forma):

$$
6,4 \mid \underline{2} \text { o } \hat{6} 4 \mid \underline{2}
$$

Una vegada repartides les desenes amb el material, anotaran numèricament el que ha ocorregut, escrivint la xifra de les desenes del quocient, especificant la subtracció intermèdia i el residu parcial, que és zero:

$$
\begin{array}{c|c}
6,4 & \frac{2}{3} \\
\hline 0 & 3
\end{array}
$$

Queden per repartir quatre unitats. Cal especificar-ho numèricament, situant la xifra de les unitats del dividend al costat del residu parcial. Això és el que es coneix com 
a baixar la xifra següent: aquesta acció té un sentit més complet quan treballem els residus parcials diferents de zero, però ara els direm que col·loquem el 4 al costat del 0 per indicar que només queden 4 unitats a repartir. Si el deixàrem dalt, podria no veure's clar en estar al costat del 6:

$$
\frac{6,4,}{\frac{-6}{04}} \frac{2}{3}
$$

Una vegada han repartit les unitats, anoten en el quocient la xifra corresponent a les unitats, així com la subtracció associada:

$$
\begin{array}{l|l}
6,4, & \frac{2}{32} \\
\frac{-6}{04} & 32 \\
\frac{-4}{0} &
\end{array}
$$

L'objectiu serà utilitzar aquest algorisme sense necessitat d'escriure les subtraccions per tal que les facen mentalment. Això és el que es coneix com a expressió estàndard de l'algorisme.

$$
\begin{array}{c|c}
6,4, & 2 \\
04 & 32 \\
\underline{0} &
\end{array}
$$

Per tornar al context de treball, respondrem a la pregunta de la situació problemàtica de partida: «Els alumnes de 3r de Primària d'un col-legi marxen d'excursió. Han d'agafar dos autobusos i, per tant, s'han de dividir en dos grups de 32 persones».

En el cas que s'acaba de treballar, els residus parcials són iguals a zero. Però en altres casos, existeix la dificultat afegida de trobar residus parcials diferents de zero que caldrà atendre treballant-la també amb materials didàctics i d'una manera semblant al procés realitzat per a residus parcials iguals a zero.

Suposem que es presenta a classe una situació problemàtica com la següent: «Els alumnes de 3r de Primària d'un col·legi marxen d'excursió i s'allotgen en un alberg. Han de repartir-se en 4 habitacions amb el mateix nombre d'alumnes. Quants alumnes hauran de posar-se en cada habitació?».

En un primer moment sembla una divisió igual a les que ja saben fer i, per tant, es disposen a realitzar-la numèricament:

$$
6,4 \mid \underline{4}
$$


Una vegada han comprovat que no és una divisió del tipus conegut, perquè no troben el 6 en la taula del 4, arribaran a la conclusió que cal tornar al material per ajudar-se a resoldre l'operació.

$\mathrm{Al}$ cas dels BM, representaran el $64 \mathrm{i}$ iniciaran el repartiment de les desenes en 4 conjunts equipotents (figura 72).

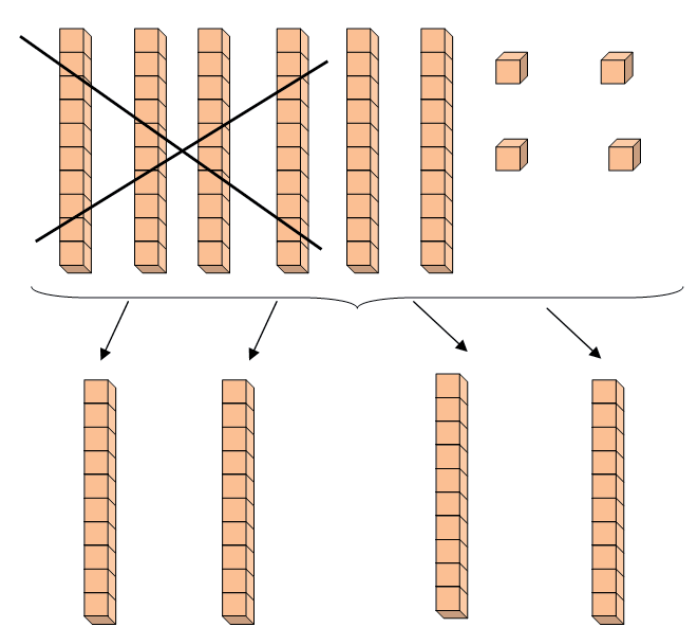

Figura 72. Representació amb вм del repartiment de les desenes de la divisió de 64 entre 4

Simultàniament a aquestes manipulacions, cal que simbolitzen numèricament el que està ocorrent:

$$
\begin{array}{c|c}
6,4 & 4 \\
\hline \frac{-4}{2} & 1
\end{array}
$$

El reglet que hem repartit en cadascun dels quatre conjunts equipotents es representa en el quocient amb un 1 que correspon la xifra de les desenes d'aquest. I el residu parcial que s'obté, el 2, es refereix als 2 reglets sense repartir.

Per la necessitat de continuar l'operació, tornen als BM i transformen en 20 cubs els dos reglets que no han pogut assignar a cap dels quatre conjunts com a desenes completes. Aleshores tenen 24 unitats per repartir (figura 73).

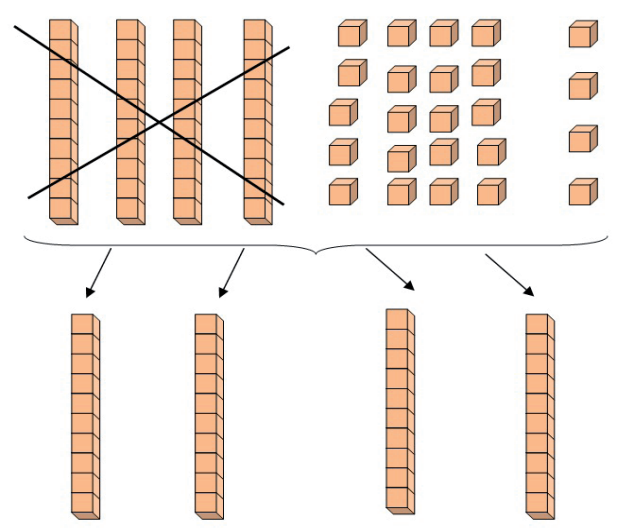

Figura 73. Representació amb BM del resultat de la descomposició de 2 reglets en 20 cubs 
La representació numèrica en aquest moment expressa el que hem esmentat anteriorment com baixar la xifra següent. Aquest fet té com a conseqüència que les dues desenes del residu parcial passen a considerar-se com a 20 unitats, que junt amb les 4 que ja hi havia en el dividend, formen les 24 que cal repartir:

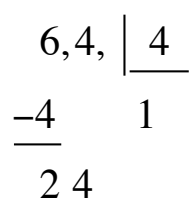

Per acabar, es reparteixen els 24 cubs en els 4 conjunts equipotents, com es veu a la figura 74 .

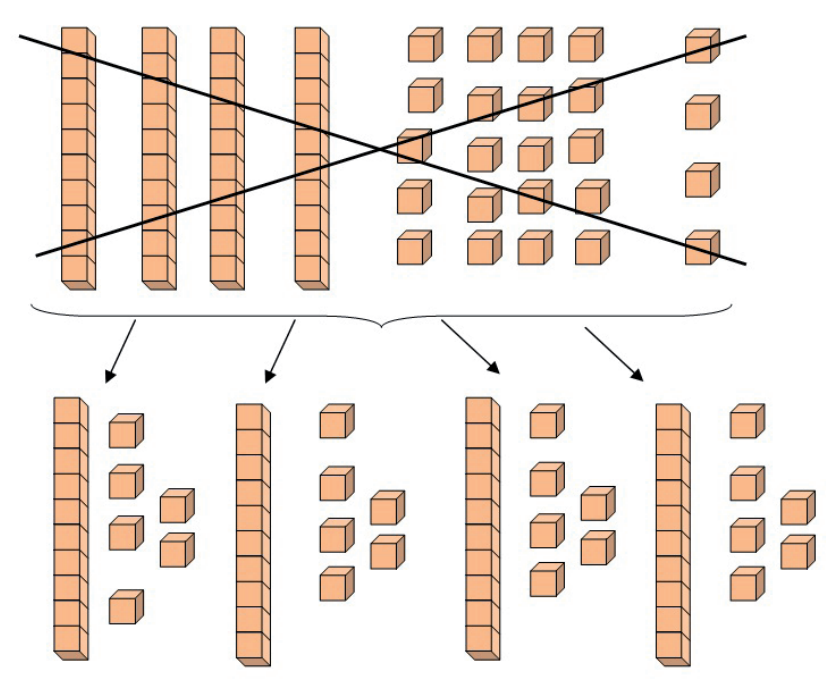

Figura 74. Representació amb BM del resultat del repartiment de 64 entre 4

Numèricament, anotarem en el quocient la xifra de les unitats i es realitzarà la corresponent subtracció parcial per finalitzar l'operació:

$$
\begin{array}{l|l}
6,4, & \frac{4}{16} \\
\frac{-4}{24} & 16 \\
\frac{-24}{00} &
\end{array}
$$

Al cas dels àbacs, representaran el dividend en un àbac i caldrà repartir-lo entre més 4. Seguint un procediment anàleg al del cas anterior, començaran per la vareta de les desenes fins que arriben a adonar-se que hi ha 2 boles que no es poden repartir. El coneixement de 1'SND i la necessitat de continuar repartint farà que decidisquen descompondre les 2 desenes en 20 unitats i afegir-les a les 4 que ja tenien. Aleshores han de repartir 24 unitats entre els 4 subconjunts, situant 6 boles en cada àbac. D'aquesta manera obtenen 1 desena i 6 unitats en cada àbac, és a dir 16 , que és el quocient. 
També ara l'objectiu serà utilitzar aquest algorisme sense necessitat d'escriure les subtraccions per tal que les facen mentalment. Això és el que es coneix com a expressió estàndard de l'algorisme.

$$
\begin{array}{c|c}
6,4, & 4 \\
24 & 16 \\
\underline{0} &
\end{array}
$$

Aquest resultat també el recontextualitzem a dins de la situació problemàtica «Els alumnes de 3r de Primària d'un col·legi marxen d'excursió i s'allotgen en un alberg. Han de repartir-se en 4 habitacions i, per tant, s'han de distribuir en quatre grups de 16 persones».

Es faran més exemples de divisions exactes amb residus parcials iguals o diferents de zero. En la reflexió amb l'alumnat sobre la relació del dividend i divisor amb el quocient, els ajudarem a què arriben a una conclusió semblant a: «per dividir un nombre de dues xifres entre un altre d'una sola, es separen les xifres del dividend, d'esquerra a dreta. A continuació es busca un nombre, que multiplicat pel divisor resulte un valor igual o proper per defecte a la xifra de les desenes del dividend, i es col·loca al quocient. El resultat d'aquest nombre multiplicat pel divisor es resta mentalment a la xifra de les desenes del dividend, i aquesta diferència es col·loca davall. Al costat d'aquest resultat baixem la xifra de les unitats del dividend. Novament cal trobar un valor que multiplicat pel divisor ens done o s'aprope per defecte al valor que en aquest moment es troba baix del dividend. Amb la col·locació del resultat final, tant del valor del quocient com del residu, tenim finalitzada la divisió, el resultat de la qual serà el nombre que es troba en el quocient». S'ha convertit una divisió de dues xifres del dividend que no sabien resoldre en dues divisions que sí que saben resoldre.

Utilitzant, per exemple, les divisions $64: 3$ i $74: 3$, se seguirà un procediment anàleg per a començar el treball amb divisions enteres per una xifra, en les quals la única diferència $\mathrm{amb}$ les anteriors serà l'existència del residu final diferent de zero.

Novament faran més exemples amb divisions exactes i enteres, amb residus parcials iguals o diferents de zero, associades a la resolució de situacions problemàtiques, fins que els alumnes utilitzen l'expressió estàndard de l'algorisme com la manera habitual de resoldre les divisions per una xifra.

Una vegada està assolida la divisió per una xifra i i ja en 4t de Primària, és el moment per introduir la divisió per diverses xifres.

Proposem ara la segona part de la seqüència didàctica ordenada per nivells de dificultat, segons la qual s'hauria d'introduir l'algorisme estàndard de la divisió quan el divisor té més d'una xifra:

1. Dues xifres en el divisor i una en el quocient: $48: 12,37: 12,124: 62$.

2. Dues xifres en el divisor i més d'una en el quocient: $946: 13,715: 26$.

3. Divisions amb zeros en el quocient: $4456: 43,556: 54$.

4. Qualsevol divisió. 
D.7. Descobrir l'algorisme de la divisió per dues xifres i utilitzar-lo per realitzar divisions en les quals augmente progressivament el nombre de xifres del dividend. Automatitzar la divisió en tots els casos

Seguim en la 3a fase d'E-A de la divisió. Ens situem a 4t de Primària i una vegada assolida la divisió per una xifra serà el moment d'ampliar el coneixement de l'algorisme estàndard d'aquesta operació, presentant una situació en què siga necessari dividir amb un divisor de dues xifres.

Per resoldre divisions on el divisor siga de diverses xifres, ja no és convenient treballar amb material didàctic, a causa de la gran quantitat de material que es necessitaria i de la dificultat de generar l'algorisme a partir de la manipulació. Una vegada arribat a aquest punt de la seqüència didàctica, passarem directament a la fase simbòlica i, per tant, farem servir llapis i paper.

Per poder fer aquestes divisions, cal que els xiquets i xiquetes siguen conscients que dividir és buscar el factor que li falta a una multiplicació, de la qual es coneix el resultat i l'altre factor.

S'introduirà la divisió per dues xifres amb una sola xifra en el quocient, començant amb una situació problemàtica en la qual siga necessari dividir, per exemple, 48 : 12: «Entre 3r i 4t de Primària hi ha 48 xiquets i xiquetes. Si volem fer 12 grups de la mateixa quantitat d'alumnes per a les activitats de Nadal, Carnestoltes, festes del poble, fi de curs, etc., de quants xiquets i xiquetes serà cada grup?».

Comentarem amb ells i elles com trobar la resposta i arribarem a la conclusió que cal resoldre la divisió de 48 entre 12, però no la saben calcular numèricament encara.

Després que diferents membres de l'alumnat presenten les seues propostes de resolució de l'operació i en la recerca de la manera comuna de fer-ho, introduirem l'algorisme corresponent plantejant-los la pregunta «què caldrà fer per trobar el quocient?». Quan la resposta siga que han de trobar un factor que multiplicat per 12 els done 48, però que desconeixen la taula del 12, els podem proposar que la confeccionen.

Així, faran: $12 \times 1=12,12 \times 2=24,12 \times 3=36,12 \times 4=48$, i en aquest punt pararan per haver arribat a la solució. Es trasllada a l'expressió numèrica de l'operació, seguint tots els passos que s'han utilitzant en les divisions d'una xifra, per tal de fixar-los:

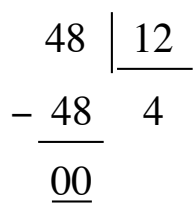

Per respondre a la pregunta de la situació problemàtica de partida, contestaran: «Si entre $3 \mathrm{r}$ i 4t de Primària hi ha 48 xiquets i xiquetes i volem fer 12 grups de la 
mateixa quantitat d'alumnes per a les activitats de Nadal, Carnestoltes, festes del poble, fi de curs, etc., cada grup serà de 4 xiquets i xiquetes»».

Es faran més exemples de divisió reflexionant amb l'alumnat sobre la relació del quocient, el dividend i el divisor, ajudant-los a què mitjançant les situacions problemàtiques treballades arriben a la conclusió: «el quocient és el nombre que multiplicat pel divisor ens dóna el dividend». Han descobert com funciona l'algorisme en aquests casos.

Els exemples inclouran divisions enteres, $37: 12$; divisions amb tres xifres en el dividend, $124: 62$, etc., utilitzant sempre pel càlcul el recurs de la construcció de la taula de multiplicar del divisor.

L'objectiu final serà utilitzar aquest algorisme sense necessitat d'escriure la subtracció per tal que la facen mentalment, el que es coneix com a expressió estàndard de l'algorisme:

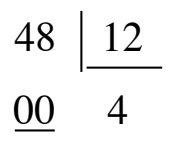

Continuant amb la seqüència didàctica de l'E-A de la divisió per diverses xifres, ens trobaríem amb una situació problemàtica en la qual apareix la divisió següent: 946 : 13, on el quocient tindrà més d'una xifra: «Preparant una excursió a Galícia amb l'alumnat de 4t de Primària sabem que des del punt de partida hi ha $946 \mathrm{~km}$. Si l'empresa d'autobusos ens ha dit que ens costaria arribar-hi 13 hores, volem saber quants kilòmetres recorrerem aproximadament en cada hora».

Intentaran calcular el quocient mitjançant la construcció de la taula del divisor, és a dir, del 13, que és l'últim procediment que han après, però s'adonen que cal fer moltes multiplicacions del tretze. Immediatament descobreixen que l'haurien de multiplicar per nombres majors que deu ja que $13 \times 10=130$, que haurien de multiplicar-lo per nombres de diverses xifres, per la qual cosa el quocient també les tindria.

Aleshores se'ls pot ocórrer, o si no els podríem ajudar a què ho descobriren, que seguint un procediment semblant a la divisió amb un divisor d'una xifra que en produeix més d'una en el quocient, caldrà separar les xifres del dividend, és a dir, elegirem dividends parcials i farem divisions parcials de divisor 13.

Com que 9 centenes no es poden repartir en 13 grups de centenes, cal descompondre-les en desenes i afegir-les a les 4 que ja hi ha, és a dir, cal agafar les dues primeres xifres del dividend, la qual cosa indicaran posant una coma; així, la divisió que ara es plantegen és 94 entre 13:

$$
94,6 \mid \underline{13}
$$


Aquesta divisió és semblant a les que s'han fet anteriorment; per tant, ja saben resoldre-la amb l'ajuda de la taula del 13: $13 \times 1=13, \ldots, 13 \times 6=78,13 \times 7=91$, $13 \times 8=104$, aleshores el quocient serà 7 . En aquest moment, traslladen el resultat parcial trobat. Caldrà insistir en el fet que aquest valor és la xifra de les desenes del quocient:

$$
\begin{array}{c|c}
94,6 & 13 \\
-\frac{91}{03} &
\end{array}
$$

Per continuar amb la divisió, baixaran la xifra següent, la qual cosa implica descompondre les 3 desenes en unitats i afegir-les a les 6 que ja hi ha, com indicaran en l'expressió numèrica de la divisió que estan fent:

$$
\begin{array}{c|c}
94,6, & 13 \\
-\frac{91}{036} & 7
\end{array}
$$

A continuació divideixen les 36 unitats i, consultant la taula del 13, troben el nou resultat parcial, que és la xifra de les unitats del quocient, i el traslladen a l'expressió numèrica de la divisió:

$$
\begin{aligned}
& \text { 94,6 } 13 \\
& -\frac{91}{036} \quad 72 \\
& -26 \\
& 10
\end{aligned}
$$

En aquest moment ja ha finalitzat la divisió, perquè s'han dividit les unitats i el residu obtingut és menor que el divisor, $\mathrm{i}$ han trobat que el quocient és 72 i que el residu és 10 .

Per tornar al context de la situació problemàtica de partida, contestaran: «En l'excursió que estem preparant a Galícia, aproximadament recorrerem $72 \mathrm{~km}$ cada hora i encara ens faltaran $10 \mathrm{~km}$ per arribar-hi».

En la reflexió amb l'alumnat sobre la relació entre els termes i els resultats de la divisió, els ajudarem que arriben a una conclusió pareguda a: «per dividir dos nombres de diverses xifres es separaran d'esquerra a dreta les xifres del dividend i fent divisions parcials del dividend entre el divisor anirem trobant les xifres del quocient». Han descobert com funciona l'algorisme estàndard en aquests casos. 
L'objectiu final serà utilitzar aquest algorisme sense necessitat d'escriure les subtraccions per tal que les facen mentalment. Això és el que es coneix com a expressió estàndard de l'algorisme:

$$
\begin{array}{c|c}
94,6, & 13 \\
036 & 72 \\
\underline{10} &
\end{array}
$$

En els exemples de resolució de situacions problemàtiques es reflexionarà també amb l'alumnat sobre la dificultat de continuar treballant amb les taules dels divisors i sobre la possibilitat d'acurtar en temps i càlculs la resolució d'aquestes divisions.

Per ajudar-los en la reflexió, podem suggerir que per deduir la primera xifra del quocient observen la relació entre la primera o les dues primeres xifres del dividend i la primera del divisor. D'aquesta manera, estan usant només les taules de multiplicar fins al 9 i els mecanismes coneguts de les divisions per una xifra, per tal d'arribar a la versió definitiva de l'algorisme estàndard de la divisió.

L'expressió numèrica no canvia, el que es modifica és el mecanisme mental per arribar-hi.

Seguint amb la seqüència didàctica i per veure el funcionament d'aquest nou mecanisme mental, ens trobaríem amb una situació problemàtica en la qual apareix la divisió 715 : 26: «En 4t curs de Primària es realitzarà una eixida a un parc d'educació vial. El preu total de l'excursió (autobús, entrada i dinar) és de $715 €$. Si el nombre d'alumnes de la classe és 26 , quants diners ha d'aportar cada un?».

Després d'identificar la divisió com l'operació que dóna resposta a aquesta pregunta, comencen la seua resolució separant les dues primeres xifres del dividend $\mathrm{i}$ intentant dividir 71 entre 26:

$$
71,5 \lcm{26}
$$

Si observen la primera xifra del dividend i la primera del divisor, poden pensar que la primera xifra del quocient serà el 3 . Comproven si el 3 és l'adequat fent els càlculs amb el divisor complet:

$$
\begin{array}{l|l}
71,5 & 26 \\
78 & 3
\end{array}
$$

Mitjançant el plantejament de la subtracció intermèdia veiem millor que el producte de 3 per 26 excedeix les xifres seleccionades del dividend, aleshores cal que proposen una altra xifra menor per al quocient, $\mathrm{i}$ tornar a fer els càlculs: 


$$
\begin{array}{r|r}
71,5 & 26 \\
-\frac{52}{19} & 2
\end{array}
$$

Han trobat el 2 com la primera xifra del quocient i 19 com a residu parcial, tots dos desenes.

Continuen fent la divisió baixant el 5, la qual cosa implica descompondre les 19 desenes en unitats en afegir les 5 i, per tant, dividirem 195 unitats entre 26:

$$
\begin{array}{r|l}
71,5, & 26 \\
-\frac{52}{195} & 2
\end{array}
$$

El procediment per resoldre aquesta nova divisió parcial és semblant al que s'ha utilitzat per resoldre la inicial, és a dir, han de buscar la xifra del quocient, relacionant el $19 \mathrm{amb}$ el 2 (s'agafa el 19 perquè l'1 és menor que el 2) i proposant el 9 com la xifra adequada:

$$
\begin{array}{l|l}
71,5, & 26 \\
-\frac{52}{195} & 29 \\
234 &
\end{array}
$$

Novament, mitjançant el plantejament de la subtracció intermèdia es veu que el 9 no ha resultat la xifra adequada $i$, amb els càlculs necessaris, arribaran a trobar el 7 com la xifra de les unitats del quocient:

$$
\begin{aligned}
& 71,5, \mid \frac{26}{27} \\
-\frac{52}{195} & \\
- & \underline{182} \\
& \underline{013}
\end{aligned}
$$

En aquest moment ja ha finalitzat la divisió, perquè s'han dividit les unitats i el residu obtingut és menor que el divisor, i han trobat el 27 com a quocient de la divisió i el 13 com a residu, aleshores: "Cada alumne de 4t curs haurà d'aportar $27 €$ per l'eixida al parc d'educació vial, i es pagaran $13 €$ del fons de la classe per completar els $715 €$ ». 
Es faran més exemples de divisió reflexionant amb l'alumnat sobre la relació de les xifres del quocient, el dividend i el divisor, ajudant-los a què mitjançant les situacions problemàtiques treballades arriben a una conclusió semblant a: «per dividir dos nombres de diverses xifres es separaran d'esquerra a dreta les xifres del dividend i fent divisions parcials del dividend entre el divisor trobarem les xifres del quocient observant la relació entre la primera o les primeres xifres del dividend $\mathrm{i}$ la primera del divisor». Han descobert com funciona definitivament l'algorisme estàndard de la divisió.

El pas final en el procés serà arribar a l'expressió estàndard de l'algorisme de la divisió, en la qual no s'expressen les subtraccions intermèdies, es fan mentalment. Si agafem l'exemple anterior:

$$
\begin{array}{l|l}
71,5, & 26 \\
195 & 27 \\
013 &
\end{array}
$$

Una vegada assolit l'algorisme de la divisió per dues xifres, s'hi introduiran situacions en les quals es vaja augmentant el nombre de xifres al dividend $i$ al divisor.

En aquest procés de resolució de diferents tipus de divisions, en poden trobar algunes que presentaran una dificultat afegida pel fet de tenir zeros entre les xifres del quocient.

Per exemple, en la divisió 4456 : 43, observaran que no es poden repartir les desenes i caldrà posar zero en la xifra de les desenes del quocient i baixar la xifra de les unitats per poder continuar la divisió:

$$
\begin{array}{c|c}
\begin{array}{c}
4,5,6, \\
0156
\end{array} & 103 \\
27 &
\end{array}
$$

Les reflexions sobre aquestes divisions els ajudaran a arribar a una conclusió del tipus: «quan no hi ha suficient quantitat de l'ordre en el qual s'estiga dividint, cal posar un zero al quocient per indicar que no hi ha unitats d'aquest ordre i hem de continuar dividint amb l'ordre següent d'esquerra a dreta».

En altres casos, per exemple $556: 54$, també trobarem zeros en el quocient, però no en una posició intermèdia:

$$
\begin{array}{l|l}
55,6 & 54 \\
\hline 016 & 10
\end{array}
$$


En aquest cas, per no poder repartir les 16 unitats entre 54, els alumnes han d'anotar en el quocient un zero en el lloc de la xifra de les unitats.

La conclusió a la qual hem d'arribar ara és: «quan no hi ha suficient quantitat d'unitats de $1 \mathrm{r}$ ordre en el dividend, cal posar un zero al quocient per indicar que no hi ha unitats d'aquest ordre i haurem acabat la divisió»».

Aquestes últimes dues situacions són d'especial dificultat, i caldrà insistir-hi perquè els xiquets i les xiquetes no obliden reflectir els zeros en el quocient en el lloc corresponent. Per solucionar-ho, seria convenient verbalitzar l'ordre d'unitats de les xifres del quocient que van trobant, perquè puguen reconèixer l'absència de quantitat en algun ordre i, a més a més, podrien detectar l'oblit si feren sempre la prova de la divisió.

D.8. Reconèixer les relacions que hi ha entre dividend, divisor, quocient i residu, i utilitzar-les com a "prova de la divisió»

Quan a finals de $3 \mathrm{r}$ o en $4 \mathrm{t}$ curs de Primària ja estiga normalitzada aquesta operació, tornarem una vegada més al significat de la divisió i reflexionarem amb l'alumnat sobre les relacions que hi ha entre els seus termes.

Partirem de divisions numèriques senzilles, que representem ací en general com:

$$
\begin{array}{l|l}
D & d \\
r & q
\end{array}
$$

i hauran de comprovar, segons els casos, que:

1) Si $r=0$, aleshores $D=d \times q$

o bé que:

2) $\operatorname{Si} r \neq 0$, aleshores $\quad D=(d \times q)+r$

A partir d'aquest moment, amb la finalitat d'aconseguir que l'alumnat es puga sentir «matemàtic» (Chevallard i altres, 1997) i responsable de la correcció dels seus resultats, s'utilitzaran aquestes relacions com a forma de comprovar si les divisions estan ben fetes.

\section{D.9. Desenvolupar l'agilitat mental en el càlcul de la divisió}

De manera espontània i de la mateixa forma que les operacions anteriors, en veu alta, dins d'un joc, en diferents situacions... i sempre a un nivell de menys dificultat del que a classe s'estiga treballant simbòlicament, utilitzarem la nova operació, la 
divisió, per exercitar el càlcul mental. Com que està íntimament relacionada amb la multiplicació, en el càlcul mental també ho estarà. És un bon moment per recordar el que s'ha treballat amb els materials al principi de la multiplicació i la divisió i fer reflexions del tipus doble o meitat, triple o dividit per tres... Només són multiplicacions i divisions per nombres molt bàsics, però es representen relacions molt incorporades a la vida real; per tant, han d'estar molt assolides pels alumnes. Ha de servir per resoldre situacions quotidianes recreades a classe.

En 4t de Primària, amb un domini clar i contrastat de les taules de multiplicar, han de dominar també el paper dels termes i les seues relacions segons s'estiga utilitzant la multiplicació o la divisió. Per exemple, amb el 2, el 3 i el 6, si és una multiplicació el que interessa resoldre en la situació concreta, el 2 pot ser multiplicand o multiplicador, igual que el 3. Ambdós són factors, i el 6 és el resultat de la multiplicació. Però si és una divisió, el 6 és el dividend i el 2 i el 3 són divisor i quocient indistintament (a banda de saber mentalment que aquesta divisió és exacta).

Anàlogament a les altres operacions, treballarem les estratègies personals que cada alumne hi ha creat per aplicar-les també a la divisió, demanant que ens verbalitzen allò que fan al calcular mentalment per assegurar-nos que estan pensant correctament.

A mesura que es va dominant aquest càlcul mental i el de les altres operacions, es pot combinar gradualment la divisió amb elles per tal de fer un treball conjunt. A més, es disposa de material que amb l'ajuda del joc, facilita el càlcul mental amb la divisió.

\section{Dòmino de la divisió (fabricat per Nardil, SL)}

Es reparteixen fitxes del joc i, per torns, han d'associar una divisió immediata per una xifra indicada numèricament amb el seu resultat (figura 75).

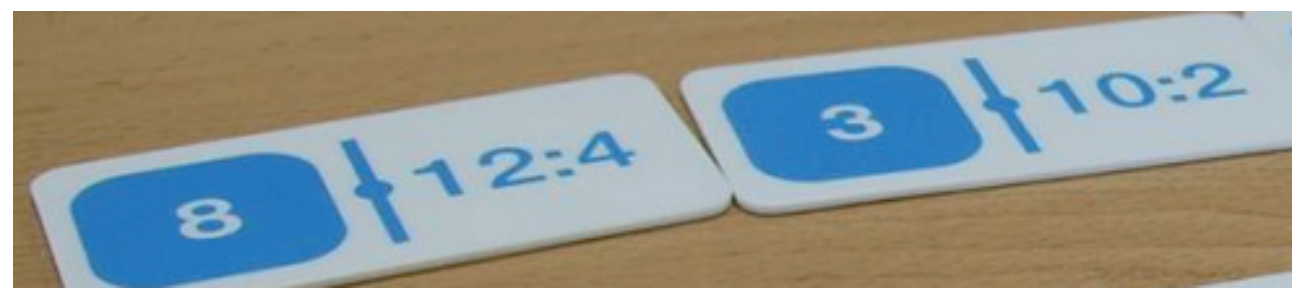

Figura 75. Imatge d'una associació de fitxes amb el Dòmino de la divisió

Triòmino de la divisió (fabricat per Taskmaster Ltd.)

De manera anàloga es reparteixen fitxes del joc i, per torns, els jugadors han d'associar una divisió indicada, de la mateixa dificultat que al joc anterior, amb el seu resultat (figura 76). 


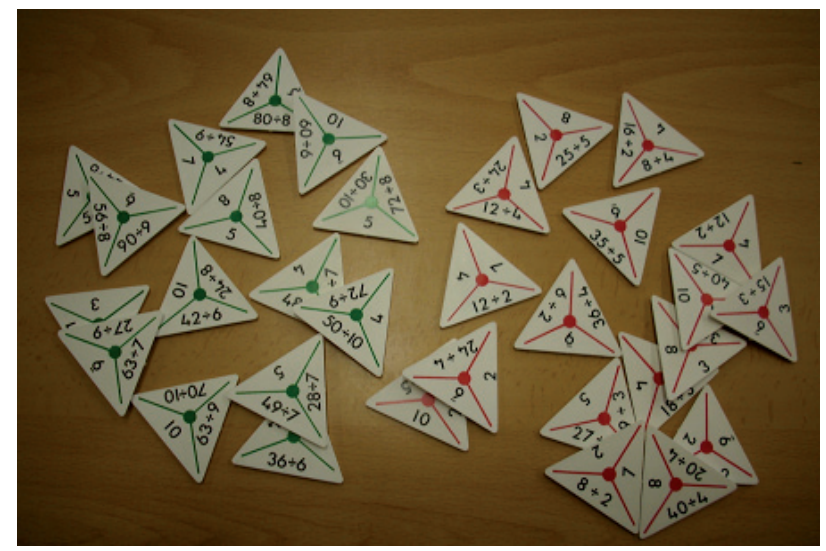

Figura 76. Imatge de les fitxes del Triòmino de la divisió

Aquest material presenta dos tipus de fitxes. Unes, amb marques de separació de color roig, tenen divisions de divisors 2, 3, 4 o 5. D'altres, amb marques de separació de color verd, tenen divisions de divisors 6, 7, 8, 9 o 10. El joc es pot plantejar separadament o combinant els dos tipus de fitxes.

S'ha comentat ja que, una vegada treballada en el càlcul mental la nova operació que ens ocupa, s'integra al treball anterior. A partir de $4 \mathrm{t}$ de Primària, ja es poden utilitzar les quatre operacions. Els materials següents barregen totes quatre i requereixen un cert domini del càlcul mental.

\section{Mathable (fabricat per Diset)}

En aquest material es reparteixen fitxes amb nombres d'una i dues xifres i les han de col-locar com a resultat d'alguna de les quatre operacions treballades feta amb els nombres de les dues caselles contigües a la que s'ocupa. A les caselles sense signe es pot realitzar qualsevol operació i a les que tenen un signe representat, l'operació que està assignada.

Cada jugador s'anota en la seua jugada la suma de tots els valors de les fitxes que col·loca i l'acumula als que ja en tenia. Guanya qui més punts fa (figura 77).

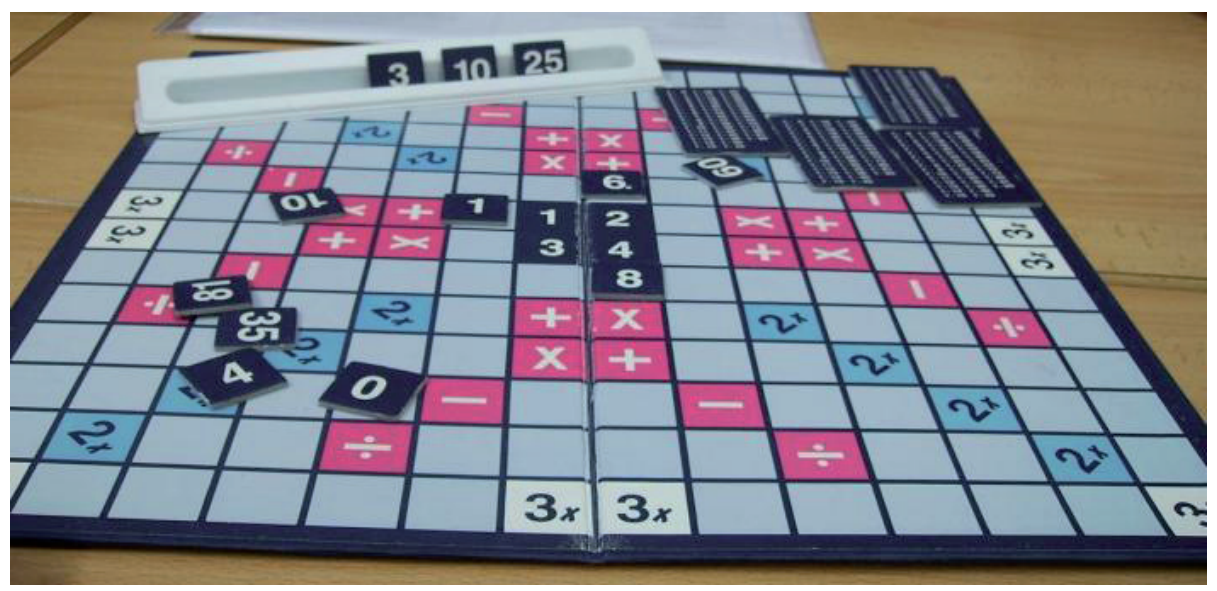

Figura 77. Imatge d'un moment del joc Mathable 


\section{El Mil (fabricat per Nardil sL)}

El material disposa d'un tauler de plàstic dividit en caselles en les quals s'indica el signe d'una de les quatre operacions treballades acompanyat per un nombre d'una, dues o tres xifres (figura 78).

En la primera tirada cada jugador partirà del centre del tauler i haurà de recórrer tantes caselles amb costat comú com indique la tirada del dau, fent l'operació assenyalada en la casella d'arribada. En les tirades següents es mourà pel tauler amb les mateixes normes, fent sempre l'operació de l'última casella. Guanyarà la partida el primer jugador que aconseguisca de manera exacta el nombre pactat al principi, 100, 500, 1.000...

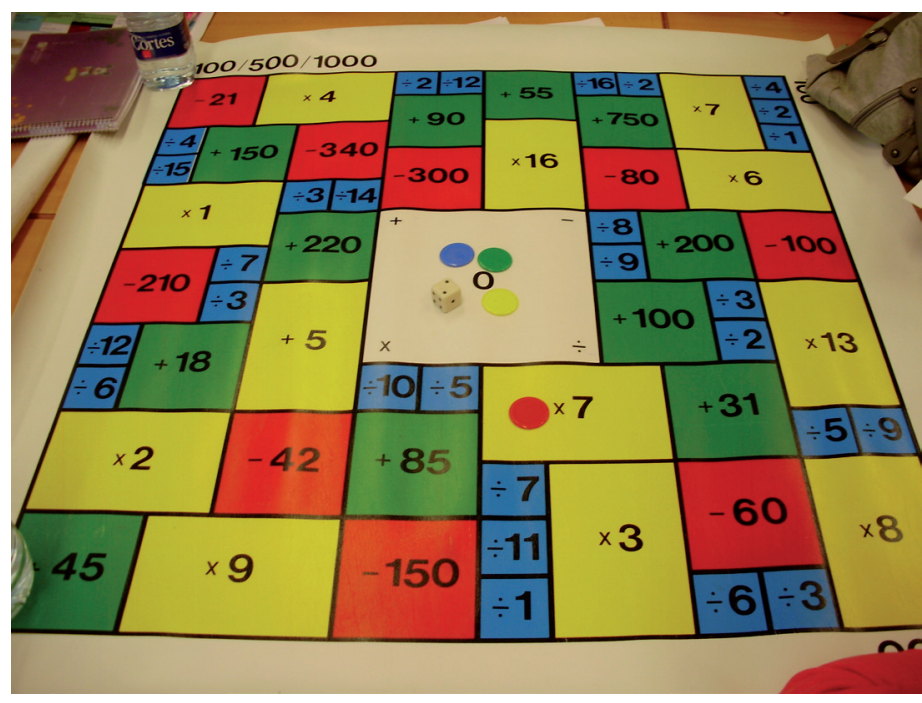

Figura 78. Imatge del tauler d'El Mil

\section{Top Score (fabricat per Diset)}

El material consta d'un dau negre decaèdric amb una xifra del 0 al 9 en cadascuna de les seues cares i de sis daus hexaèdrics, en les cares dels quals apareixen distribuïts de diferents maneres els nombres de l'1 al 9, a més de 10, 25, 50, 75 i 100 (figura 79).

Es llança el dau negre tres vegades i es compon un nombre amb les xifres obtingudes en els llançaments. Seguidament es realitza una tirada amb el cubilet i els altres sis daus. Combinant els sis nombres que s'han obtingut en aquest darrer llançament amb les quatre operacions elementals, s'ha de intentar obtenir el nombre de tres xifres o aproximar-s'hi el més possible, sempre per defecte. 


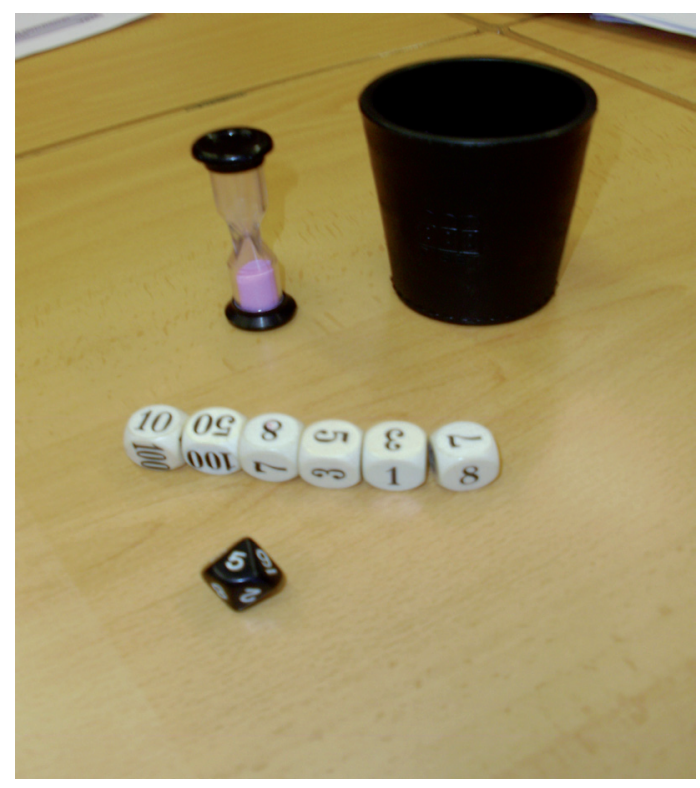

Figura 79. Imatge dels elements que componen el joc Top Score

\section{D.10. Resoldre i inventar situacions problemàtiques relacionades amb la divisió}

Com ja s'ha esmentat anteriorment, és en situacions reals on cobra especial sentit el treball fet amb aquesta operació, perquè realment és la realitat la que origina interrogants la resposta dels quals passarà per saber, en aquest cas, resoldre divisions.

Anàlogament a les altres operacions, encara que la resolució i la invenció de problemes apareix com la quarta fase per treballar-les, també ara ens trobem en ella des del principi, perquè presentem les divisions de manera contextualitzada, a partir de situacions reals que han de resoldre's i que, igualment, estaran relacionades amb qualsevol bloc de continguts matemàtics.

Continuarem treballant la resolució de problemes a partir de les quatre fases de Polya i de la reflexió amb l'alumnat sobre la seua importància, desenvolupament i utilitat.

Com s'ha comentat en les capacitats A.9, B.9 i C.11 i amb les mateixes consideracions, aprofitarem els errors per generar nous aprenentatges i continuarem amb el treball d'estimació dels resultats de les situacions problemàtiques.

Iniciarem el treball en $3 r$ de Primària, amb problemes que necessiten ser resolts amb una divisió. És molt important que, en els primers moments, prestem atenció de manera individual a cadascuna de les diferents situacions utilitzades per introduir l'operació (d'agrupament i de repartiment). Així, cada vegada que introduïm un nou tipus de situacions per a la divisió, haurem de treballar la resolució de problemes relacionats amb elles, per reforçar el significat de l'operació que tenen associat i el paper dels seus termes en cada cas. 
També haurem de dedicar atenció, al principi de manera específica, als dos tipus de divisió que hem treballat, les exactes i les enteres, plantejant de manera separada problemes que es resolguen amb divisions de les dues classes i aprofitant aquest treball per insistir en les diferències entre elles i en la utilització del vocabulari associat.

Quan ja reconeguen la divisió com l'operació que serveix per resoldre qualsevol de les situacions esmentades, plantejarem problemes relacionats amb elles tenint cura que les divisions apareguen de manera aïllada.

Més endavant treballarem problemes que necessiten dues divisions per a la seua resolució i, cap al final de $3 \mathrm{r}$ curs o ja en 4t, es poden proposar problemes que necessiten, per ser resolts, la combinació d'una divisió amb alguna de les altres operacions.

En referència als enunciats de les situacions problemàtiques seguirem els mateixos passos que en les operacions anteriors (capacitats A.9, B.9 i C.11), però en aquest cas, l'aparició de problemes amb enunciats confusos, incomplets, amb dades que falten, amb dades que sobren..., relacionats en la divisió, hauria de retardar-se fins al darrer curs del $2 \mathrm{n}$ cicle, per donar temps a l'alumnat a fi que assolisca millor l'operació.

Cap al final de 3r curs, iniciarem també el desenvolupament de tasques d'invenció de problemes relacionats amb la divisió, amb les mateixes orientacions donades en els altres casos (capacitats A.9, B.9 i C11), tant referides a l'oferiment d'ajudes a l'alumnat com a la necessitat d'intercanviar entre els xiquets i les xiquetes els enunciats inventats.

En el $3 \mathrm{r}$ cicle es continuarà amb les tasques de resolució i invenció de situacions problemàtiques relacionades amb la divisió, en les quals aquesta operació es combinarà amb les altres tres a mesura que les vagen dominant. 


\section{TEMA 3}

\section{Divisibilitat en Nombres Naturals}

En aquest tema es treballa el tractament didàctic de la divisibilitat amb Nombres Naturals a partir de la construcció dels conceptes associats a ella d'una manera molt intuïtiva i que es puguen abordar pels alumnes de $3 \mathrm{r}$ cicle de Primària.

\section{Introducció}

\subsection{De caràcter general}

Des de fa més de 2.000 anys, els nombres primers atrauen l'atenció de matemàtics i aficionats de tot el món, per diverses raons. Una és la fascinació que produeix la irregular distribució d'aquests nombres al llarg de la recta numèrica. Els nombres primers apareixen escampats ací i allà i es troben sectors on abunden i d'altres on escassegen.

Euclides, ja aleshores, ens assegurà que el conjunt de nombres primers és infinit, igual que el conjunt numèric al qual pertanyen, els Nombres Naturals. Ho va demostrar utilitzant propietats de la divisibilitat dels Nombres Naturals, en el llibre IX d'Els Elements.

El conjunt dels Nombres Naturals diferents de la unitat està format per dos grans subconjunts de nombres, els que s'anomenen primers (aquells que es poden dividir només per si mateix i per la unitat) i els compostos, que són la resta. L'estudi de la divisibilitat en el conjunt dels naturals permet esbrinar si un nombre natural donat pertany a un d'aquests subconjunts o a l'altre.

Històricament s'han donat als nombres primers connotacions màgiques, místiques, fora de l'àmbit numèric. Se'ls qualifica de misteriosos i indomables ja que sembla que no hi ha cap regla que determine la seua ubicació entre la resta de Nombres Naturals. Han estat investigats, estudiats, treballats... Hi ha un problema obert: la conjectura de Golbach. L'any 1742 Goldbach envia una carta a Euler dient «tot nombre senar més gran que 5 és la suma de 3 nombres primers». Per exemple $15=3+5+7$. Euler, en respondre, estableix la coneguda com a conjectura de Goldbach que diu «Tot nombre parell més gran que 2 és suma de dos nombres primers».

Si es pensa que pot ser una curiositat, n'hi ha més, com ara els nombres primers bessons, aquells la diferència entre els quals es de 2 unitats $((5,7),(11,13)$, 
$(821,823) \ldots)$. En el món cinematogràfic apareixen també referències als nombres primers en la pel·lícula Contact (dirigida per Robert Zemeckis l'any 1997; basada en una novel·la de Carl Sagan), on són els nombres primers la manera de comunicar-se els alienígenes amb nosaltres i, més recentment, en La habitación de Fermat (direcció i guió Luis Piedrahita i Rodrigo Sopeña, 2007) on la conjectura de Goldbach forma part essencial de la història.

Però no es tracta d'un tema desconnectat de la realitat. Podem pensar que un concepte l'origen del qual està al segle III a. C. amb Euclides i amb un tractament inicial d'aparell matemàtic tan elemental es pot veure apartat de la ciència actual. Però no és el cas. En els últims anys, pel que fa als nous avantatges tecnològics, com la informació en xarxa (Internet), ha estat necessari crear mètodes per garantir la seguretat d'aquesta informació, moltes vegades econòmica, personal, que ens afecta directament. El sostre matemàtic d'aquest tema ha evolucionat i s'ha fet molt complex. La part de l'àlgebra, i més concretament de la teoria de nombres, que s'encarrega de proporcionar aquesta seguretat (codificant informació) s'anomena criptografia. Un dels mètodes més populars emprats en criptografia és el que es coneix com a RSA, en honor dels seus creadors R. L. Rivest, A. Shamir i L. Adleman. La seguretat del mètode es fonamenta en la dificultat de factoritzar, d'una manera concreta i que resulte eficient i eficaç, els nombres naturals que són producte de dos nombres primers molt grans. Les implementacions més elaborades del mètode RSA (així com també d'altres similars) utilitzen lleis aritmètiques profundes, el coneixement de les quals seria inimaginable sense el suport teòric que s'ha desenvolupat a l'entorn dels nombres primers.

\subsection{De caràcter específic}

És evident que el que s'ha exposat a la primera part d'aquesta introducció no apareixerà en l'aula de Primària, encara que es pot aconseguir una crida a l'interès amb curiositats com aquestes. Però sí que serà necessari posar nom a conceptes que al llarg de tota la seua vida matemàtica hauran d'utilitzar, com ara factor, divisor, múltiple, divisible... Que aquest nom siga precís, i que s'identifique clarament amb el concepte matemàtic que hi ha a sota, és l'objectiu.

Realment, a l'aula de Primària es demana que s'inicie a la divisibilitat de Nombres Naturals, concretament als múltiples i divisors d'un nombre, utilitzant la taula de multiplicar per trobar els múltiples i divisors d'un nombre menor o igual que 100 . També s'exigeix conèixer els nombres primers i els compostos i, a més a més, els criteris de divisibilitat per 2, 3, 5, 9 i 10, per usar-los en la descomposició en factors primers d'un nombre menor que 1.000 .

En el desenvolupament d'aquest tema hem considerat adequat no separar en capacitats tal com s'ha fet en els temes anteriors, perquè el treball que es proposa amb aquests conceptes és un continu que porta d'un a l'altre i tal com es faria en un aula de 6è de Primària. 
Però volem anar un poc més enllà. Pensem que ens trobem davant d'un problema important en didàctica de la Matemàtica pel que fa a la divisibilitat de Nombres Naturals: el càlcul del màxim comú divisor i del mínim comú múltiple. Apostem per introduir-lo a l'aula de Primària, encara que no n'hi ha recomanació oficial, perquè dóna coherència a tot el treball previ, i perquè facilita els càlculs amb fraccions. Tan important o més que el càlcul serà entendre el concepte $\mathrm{i}$ la utilitat en molts problemes de la vida quotidiana. Constatem reiteradament en les nostres relacions amb alumnes $i$ estudiants que el procediment per calcular aquests valors ha suplantat la mateixa definició dels conceptes.

Pel que s'ha esmentat, el moment d'introduir aquest tema en Primària serà en 6è, una vegada ja estiguen assolides la multiplicació i la divisió, i s'intentarà que siga un aprenentatge significatiu; per tant, respectarem els ritmes de l'alumnat, treballarem el descobriment dels conceptes i provocarem la construcció de nous instruments matemàtics que resolguen de manera més eficaç els problemes plantejats. Com a material manipulatiu es pot treballar amb els blocs multibase de Dienes i els reglets Cuisenaire pel càlcul de múltiples i divisors.

Amb els reglets Cuisenaire, per exemple, pel càlcul dels múltiples d'un nombre, elegirem el reglet que el representa i farem trens repetint aquest, i obtindrem així trens del color del reglet. Aquests trens seran representacions de múltiples del nombre inicial.

Per calcular divisors d'un nombre elegirem el reglet que el representa i farem trens amb reglets tots iguals de la mateixa llargària del reglet triat. Cadascun dels reglets que componen cada tren, representa un divisor del nombre elegit.

\subsection{Posant-hi nom}

Si reflexionem a partir de la multiplicació $45=5 \times 9$, podrem dir que:

- 45 és múltiple de 5 i de 9

- 5 i 9 són divisors de 45

- 45 és divisible per 5 i per 9

- 5 i 9 són factors de 45

Aquestes paraules: múltiple, divisor, divisible i factor, ja les coneixen del treball amb les operacions multiplicació i divisió. Cal adonar-se dels matisos i concloure que, depenent del punt de vista (l'operació) des del qual s'observa l'escenari, a un mateix actor se l'anomenarà d'una manera o d'altra. És a dir, si l'operació és la multiplicació, parlarem de múltiple i factor. Si l'operació és la divisió, els mots seran divisor i divisible. Però el que ha de quedar clar és que múltiple té un significat equivalent a divisible, i divisor equivalent a factor, tenint en compte que el zero mai pot ocupar el lloc d'un divisor.

Aquest fet fonamentarà la construcció del tema. 


\section{Múltiples i divisors dels Nombres Naturals}

\subsection{Definició de múltiple d'un nombre natural}

Quan s'ha vist l'exemple en la introducció, pocs de nosaltres i pocs dels xiquets i xiquetes haurien dubtat a dir que 45 és múltiple de 5. Però per què? Què és el que fa que un nombre siga múltiple d'un altre? Una primera aproximació, si mirem des del punt de vista de la multiplicació, serà perquè el 45 conté 9 vegades el $5 \mathrm{o}$, el que és el mateix, perquè 9 per 5 és 45 . Si l'aproximació la fem des del punt de vista de la divisió, 45 dividit entre 5 és una divisió exacta i ens dóna 9 com a quocient. Aquestes són, doncs, les possibles dues definicions de múltiple:

- Un nombre a és múltiple d'un altre $\mathbf{b}$, quan la divisió «a entre b» és exacta.

- Un nombre a és múltiple d'un altre $\mathbf{b}$, quan «a és divisible per $\mathbf{b} »$, és a dir, existirà un nombre $\mathbf{c}$, de tal manera que $\mathbf{a}=\mathbf{b} \times \mathbf{c}$.

Formalment: $\forall a, b \in \mathrm{N}, a=\dot{b} \leftrightarrow \exists c \in \mathrm{N} / a=b \times c$, on el punt sobre la b és la manera d'indicar en llenguatge matemàtic que a és múltiple de $\mathbf{b}$.

Per tant, cal transmetre a l'aula de Primària que un múltiple no nul d'un nombre natural és un nombre més gran o igual que el mateix nombre.

\subsection{Propietats de múltiple d'un nombre natural}

1. Qualsevol nombre sempre és múltiple de si mateix.

Per exemple, si considerem el 6: $6=6 \times 1$.

2. La suma (diferència) de múltiples d'un nombre és també múltiple d'aquest nombre.

Per exemple, si considerem el 3: 6 és múltiple de 3; 9 és múltiple de 3 i $6+9=15$ és múltiple de 3 i $9-6=3$ és múltiple de 3 .

3. El producte de múltiples d'un nombre és també múltiple d'aquest nombre. Per exemple, si considerem el 3: 6 és múltiple de 3; 9 és múltiple de 3 i 54 és múltiple de $3(54=3 \times 18)$.

4. Si un nombre és múltiple d'un altre, $i$ aquest ho és d'un tercer, el primer nombre és múltiple del tercer.

Per exemple, si considerem el 12: 12 és múltiple de 6, 6 és múltiple de 3 i 12 és múltiple de 3 .

Amb més exemples semblants, s'assoliran aquestes propietats. 
En un primer moment es pot pensar que semblen poc pràctiques. Cal revisar-les un poc més per descobrir que ofereixen moltes possibilitats i aplicacions. Per exemple:

- És 72 un múltiple de 12 ? Sí que ho és perquè $72=60+12$, i 60 és múltiple de 12 i 12 també ho és (propietat 2).

- És 72 múltiple de 3? Sí que ho és perquè $72=12 \times 6$ i 12 i 6 sí que ho són (propietat 3).

- És 600 múltiple de 15 ? Sí que ho és perquè $600=20 \times 30$ i $30=15 \times 2$ (propietat 4).

\subsection{Definició de divisor d'un nombre natural}

De la mateixa manera que ha passat en el cas de múltiple, quan s'ha vist l'exemple en la introducció, tampoc no hauríem dubtat a dir que 5 és divisor de 45. L'explicació en aquest cas és encara més senzilla. Com que l'última operació ha sigut la divisió i es té clar el concepte de divisor, aleshores de $45: 5=9$, el divisor és 5 i, el que és el mateix, $45=5 \times 9$; per tant, 5 és un dels factors de 45 . Ja és clara l'equivalència entre divisor i factor.

Aleshores, aquestes són les possibles dues definicions de divisor:

- Un nombre a és divisor d'un altre b, quan la divisió «b entre a» és exacta. (Cal notar el canvi de papers entre $a$ i $b$ a la definició de múltiple i divisor.)

- Un nombre a és divisor d'un altre b, quan a és un factor de b. (Cal notar que es tracta d'una altra manera de dir el mateix que ser divisible per, però canviant els papers de $a$ i de $b$.)

Formalment: $\forall a, b \in \mathrm{N}, a \mid b \leftrightarrow \exists c \in \mathrm{N} / b=a \times c$, on la barra vertical que separa a i $\mathbf{b}$ és la manera d'indicar en llenguatge matemàtic que a és divisor de $\mathbf{b}$.

Per tant, cal transmetre a classe que un divisor d'un nombre natural és un nombre més menut o igual que aquest nombre.

\subsection{Propietats de divisor d'un nombre natural}

1. Qualsevol nombre sempre és divisor de si mateix (conseqüència directa de la 1a propietat de múltiple).

2. Si un nombre és divisor d'altres dos, ho és també de la suma, de la diferència $i$ del producte d'aquests (conseqüència directa de les propietats $2 \mathrm{a}$ i 3a del múltiple).

3. Si un nombre és divisor d'un altre, i aquest ho és d'un tercer, el primer nombre també és divisor del tercer (conseqüència directa de la 4a propietat del múltiple). 


\section{Criteris de divisibilitat}

La divisibilitat amb Nombres Naturals permet fer càlculs amb estratègies que donen rapidesa i agilitat a les operacions. Els criteris de divisibilitat són un exemple. Sense ser essencials pel fet de calcular, en conèixer-los es facilita molt aquesta tasca.

Mai s'ha d'entendre que són regles que cal donar i aplicar. L'alumnat haurà de construir-les des dels exemples que els orientaran a elaborar l'enunciat del criteri, fins a la comprovació, en un nombre considerable d'ocasions de la regla que han enunciat.

Per exemple, cal fer la reflexió que un nombre no és que siga divisible per 2 perquè hi ha un criteri que ho diu, sinó que hi ha un criteri de divisibilitat per 2, perquè tots els nombres que són divisibles per 2 el verifiquen. Per això, aquesta norma que tots compleixen s'anomena criteri de divisibilitat per 2. I és aquesta la que han d'arribar a poder enunciar a partir dels exemples treballats.

Finalment, una vegada construïts, podem dir que els criteris de divisibilitat són unes regles que ens permeten saber si un nombre és o no divisible per un altre (o múltiple d'un altre) sense necessitat de fer la divisió.

A l'aula de Primària aquests criteris s'han de treballar en bloc una vegada s'arribe al punt de tenir diferenciats els conceptes dels epígrafs anteriors. En aquest apartat s'exposaran els criteris de divisibilitat de més nombres naturals, però, en Primària, els que l'alumnat ha d'obtenir i treballar són els del 2, 3, 5, 9 i 10.

N'hi ha que són més intuïtius, com per exemple el del 2. I que els xiquets i les xiquetes arriben a la conclusió dependrà de la quantitat de repeticions de divisions per 2 que hi facen en el seu moment o en aquest. En treballar la multiplicació i la divisió se'ls va fer caure en el fet que qualsevol nombre parell genera una divisió exacta en dividir-lo entre $2 \mathrm{i}$ ara utilitzem aquest resultat per obtenir el corresponent criteri. Generalment, quan es fa una divisió ens interessa particularment el quocient $i$ el residu, encara que ara per arribar a construir el criteri de divisibilitat per 2 serà necessari fixar-se en el dividend, i consegüentment, arribar a adonar-se que un nombre és divisible entre 2 quan termina en xifra parella.

De la mateixa manera pot passar amb el 5, 10, 100, 1.000... Altres criteris no són tan intuïtius, com ara el del $7,11 \ldots$ Els més complicats no es podran deduir, caldrà enunciar-los i aplicar-los. S'ha d'insistir en el fet que arribar a elaborar un criteri de divisibilitat ha estat el resultat de l'estudi, durant molt de temps, de les propietats dels nombres per part d'alguna persona que ha arribat a aquesta conclusió. No és màgia. 
Aleshores, els criteris de divisibilitat s'enuncien com:

1. Criteri de divisibilitat per 2:

Un nombre és divisible per 2 quan la xifra de les unitats és múltiple de 2 (és un nombre parell).

2. Criteri de divisibilitat per 3:

Un nombre és divisible per 3 si la suma de les seues xifres és múltiple de 3.

3. Criteri de divisibilitat per 4:

Un nombre és divisible per 4 quan el nombre format per les dues últimes xifres és múltiple de 4.

Exemple: $1.516,1.504,100 \ldots$

4. Criteri de divisibilitat per 5:

Un nombre és divisible per 5 quan la xifra de les unitats és 0 o 5 .

5. Criteri de divisibilitat per 6:

Un nombre és divisible per 6 quan ho és per 2 i per 3.

Exemple: 144: és parell, i $1+4+4=9$.

6. Criteri de divisibilitat per 7:

Un nombre és divisible per 7 quan la diferència entre el nombre sense la xifra de les unitats i el doble de la xifra de les unitats és múltiple de 7 (en el sentit que es puga fer aquesta resta).

Exemple: $343: 34-6=28$ múltiple de $7(7 \times 4)$.

$749: 74-18=56$ múltiple de $7(7 \times 8)$.

$91: 9-2=7$ múltiple de 7 .

$77: 7-14 \ldots$ no es pot calcular; $14-7=7$ sí que es pot calcular.

7. Criteri de divisibilitat per 8:

Un nombre és divisible per 8 quan el nombre format per les tres últimes xifres és múltiple de 8 . Si el nombre té menys de tres xifres, cal fer la divisió. Exemple: 5.888, 1.016, 1.000...

8. Criteri de divisibilitat per 9:

Un nombre és divisible per 9 si la suma de les seues xifres és múltiple de 9. Exemple: $729: 7+2+9=18$.

9. Criteri de divisibilitat per 10:

Un nombre és divisible per 10 si la xifra de les unitats és zero.

Exemple: 120, 1.540.

10. Criteri de divisibilitat per 11:

Un nombre és divisible per 11 quan la diferència entre la suma de les xifres que ocupen lloc parrell i la suma de les que l'ocupen imparell, en el sentit possible, és múltiple d'11.

Exemple: $3.817:(8+7)-(3+1)=15-4=11$. 
11. Criteri de divisibilitat per 12:

Un nombre és divisible per 12 quan ho és per 3 i per 4.

Exemple: $288: 2+8+8=18$; per tant, 288 és múltiple de 3 i 88 és múltiple de 4.

12. Criteri de divisibilitat per 25:

Un nombre és divisible per 25 quan el nombre format per les últimes dues xifres és múltiple de 25.

Exemple: $175: 75$ és múltiple de 25.

13. Criteri de divisibilitat per 100:

Un nombre és divisible per 100 si les últimes xifres són dos zeros.

Exemple: 2.700 .

14. Criteri de divisibilitat per la unitat seguida de zeros:

Un nombre és divisible per $1.000,10.000 \ldots$ si les últimes xifres són tres, quatre... zeros.

Nota: Els criteris de divisibilitat es poden combinar (com es veu per exemple en el cas del 6), però podem trobar que un nombre siga a la vegada múltiple de molts nombres, per exemple de $2,3,5 \ldots$ i aleshores, les possibilitats es multipliquen fent massa complicats aquests criteris (alguns d'aquests casos serien 30, $60,90 \ldots)$.

\section{Nombres primers i compostos}

\subsection{Nombres primers}

Com s'ha comentat en la introducció, quan es parla de nombres primers és obligat parlar d'Euclides. Per la distància cronològica que ens separa i per les dades poc fiables de què disposem, s'arriba a dubtar que existira. N'hi ha tres teories:

1. Euclides va existir i va fer les obres que se li atribueixen. Va nàixer al voltant de l'any 325 a. C. i va morir cap al 265 a. C.

2. Euclides era el cap d'un equip de matemàtics que treballaven a la biblioteca d'Alexandria. Entre tots van escriure les obres que ell firmava.

3. Euclides no va existir. Les obres atribuïdes a Euclides van ser escrites per un equip de matemàtics que van agafar aquest nom d'un personatge real (Euclides de Megara) que va viure cent anys abans.

El fet històric és interessant per si mateix, però el que porta el personatge d'Euclides al nostre tema és la producció que desenvolupa. L'obra més important, sens dubte, d'Euclides (i potser de les Matemàtiques) és Els elements. S'han fet més de 
mil edicions d'aquest llibre des del segle IX i és, per aquest fet, el matemàtic més llegit de tota la història.

En aquest llibre destaca la claredat amb què es plantegen els problemes i el rigor amb el qual són provats els teoremes, tot contrastant amb la datació. El teorema que ens assegura l'estructura d'aquest tema és el que s'ha anomenat teorema fonamental de l'aritmètica i que diu: «qualsevol nombre natural major que 1 es pot descompondre de manera única en factors primers».

La demostració d'aquest teorema s'obviarà, però es tracta de trobar l'existència d'aquesta descomposició per qualsevol nombre natural major que 1 i, a més a més, la unicitat d'aquesta descomposició.

Però no acabant encara amb la història, hi ha un altre personatge que ens interessa. És Eratòstenes. Va nàixer a Cyrene (ara Líbia) també en el segle III a. C. i va ser un reconegut astrònom, geògraf, matemàtic i filòsof grec. També va formar part de l'Escola d'Alexandria i va dirigir la seua biblioteca per encàrrec de Ptolomeu III. Pel fet que és més conegut i pel qual ocupa un destacat lloc arreu dels llibres de Matemàtiques és per la seua manera de trobar els nombres primers. Aquesta contribució a la nostra formació matemàtica s'anomena Garbell d'Eratòstenes. Cal dir que també se li adjudica la mesura, amb extraordinària precisió, de la longitud del meridià terrestre i les distàncies de la Terra al Sol i a la Lluna. Els seus estudis versen sobre gramàtica, filosofia, matemàtiques i astronomia. Al final de la seua vida es va veure afectat per la ceguesa i va morir de fam, per voluntat pròpia, l'any 194 a. C. a Alexandria.

El mètode per aconseguir els nombres primers és el següent: partim de la quantitat de nombres naturals distints de l'1 que es vulga, es posa una marca als múltiples de dos (parells) distints d'ell, als múltiples de 3 distints d'ell. De manera anàloga amb el $5,7,11 \ldots$ i els que no tinguen marca seran els nombres primers.

El fet d'anar eliminant els nombres compostos és el paral·lelisme amb el fet de passar pel crivell o sedàs els cereals. De manera que els que no passen per aquest crivell són els nombres primers.

El conjunt dels nombres primers és infinit, i la demostració és per reducció a l'absurd, considerant que és finit i arribant a la conclusió que aquesta hipòtesi és falsa.

En general, per determinar si un nombre es primer no cal dividir-lo entre tots els nombres menors que aquest nombre. Si és parell, diferent de 2, és compost. Si és imparell, n'hi ha prou de dividir-lo entre els nombres imparells menors o iguals que l'arrel quadrada del nombre. Si no es troba cap divisor entre ells, aleshores és primer; en cas contrari, és compost. 
A continuació tenim una llista dels 100 primers nombres primers:

\begin{tabular}{|c|c|c|c|c|c|c|c|c|c|}
\hline $\mathbf{2}$ & $\mathbf{3}$ & $\mathbf{5}$ & $\mathbf{7}$ & $\mathbf{1 1}$ & $\mathbf{1 3}$ & $\mathbf{1 7}$ & $\mathbf{1 9}$ & $\mathbf{2 3}$ & $\mathbf{2 9}$ \\
\hline 31 & 37 & 41 & 43 & 47 & 53 & 59 & 61 & 67 & 71 \\
\hline 73 & 79 & 83 & 89 & 97 & 101 & 103 & 107 & 109 & 113 \\
\hline 127 & 131 & 137 & 139 & 149 & 151 & 157 & 163 & 167 & 173 \\
\hline 179 & 181 & 191 & 193 & 197 & 199 & 211 & 223 & 227 & 229 \\
\hline 233 & 239 & 241 & 251 & 257 & 263 & 269 & 271 & 277 & 281 \\
\hline 283 & 293 & 307 & 311 & 313 & 317 & 331 & 337 & 347 & 349 \\
\hline 353 & 359 & 367 & 373 & 379 & 383 & 389 & 397 & 401 & 409 \\
\hline 419 & 421 & 431 & 433 & 439 & 443 & 449 & 457 & 461 & 463 \\
\hline 467 & 479 & 487 & 491 & 499 & 503 & 509 & 521 & 523 & 541 \\
\hline
\end{tabular}

\subsection{Nombres compostos}

Es podria dir que els nombres compostos són els elements del complementari del subconjunt de nombres primers respecte del conjunt de Nombres Naturals diferents de la unitat, és a dir, qualsevol nombre natural diferent d'1 que no és primer.

Una definició un poc més acurada seria: un nombre natural serà compost si el podem descompondre en altres factors que no són ni el mateix nombre ni la unitat. D'una altra manera, un nombre natural serà compost si té divisors diferents de si mateix i de la unitat.

A l'aula de Primària, arribar a la conclusió que la millor descomposició en factors d'un nombre és la de nombres primers, caldria que no fóra enunciativa, sinó constructiva. Una manera d'aconseguir-ho és traure els divisors d'un nombre gran, sense posar cap restricció. Per exemple, 60.

Aleatòriament, els alumnes proposaran divisors i tots seran bons:

$60=2 \times 30 \quad 60=3 \times 20 \quad 60=4 \times 15 \quad 60=5 \times 12 \quad 60=6 \times 10$

Les preguntes poden ser, «els tenim tots? Hi ha un mètode per tal de trobar-los tots?».

Per tractar de respondre podríem passar a descompondre els divisors ja trobats, per exemple:

$60=2 \times 30=2 \times 2 \times 15=2 \times 2 \times 3 \times 5$ o bé $60=2 \times 30=2 \times 3 \times 10=2 \times 3 \times 2 \times 5$

$60=3 \times 20=3 \times 2 \times 10=3 \times 2 \times 2 \times 5$ o bé $60=3 \times 20=3 \times 4 \times 5=3 \times 2 \times 2 \times 5$

$60=4 \times 15=2 \times 2 \times 15=2 \times 2 \times 3 \times 5$ o bé $60=4 \times 15=4 \times 3 \times 5=2 \times 2 \times 3 \times 5$

$60=5 \times 12=5 \times 2 \times 6=5 \times 2 \times 2 \times 3$

$60=6 \times 10=2 \times 3 \times 10=2 \times 3 \times 2 \times 5$ o bé $60=6 \times 10=6 \times 2 \times 5=2 \times 3 \times 2 \times 5$ 
Cosa amb la qual trobem d'una manera natural que, en tots els casos, s'arriba a la descomposició en factors primers, i que de manera consensuada expressem així: $60=2 \times 2 \times 3 \times 5$.

Per mitjà de més exemples traurem la conclusió que «la descomposició en factors primers unifica i aclareix totes les descomposicions», que a més a més és una manera de comprovar constructivament el teorema fonamental de l'aritmètica.

Per simplificar l'obtenció d'aquesta descomposició es recomana que es comencen a buscar factors primers en els nombres més menuts, en primer lloc per 2 , per $3 \ldots$ S'introdueix una nova forma de representació, que utilitza una línia vertical, on a la part de l'esquerra s'indiquen els quocients de les divisions exactes, els divisors de les quals es col·loquen a la dreta, fins a arribar al quocient 1 . Per exemple, en el cas del 60:

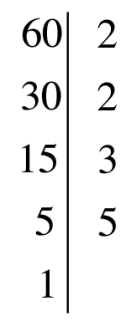

Aleshores, la descomposició del 60 en factors primers seria: $60=2 \times 2 \times 3 \times 5$.

En aquest punt ja es poden començar a respondre les preguntes de saber tots els divisors de 60 i de trobar un mètode per tal de calcular-los. Es dirigeixen les preguntes fins a arribar al punt que tots els divisors que els alumnes havien proposat són també productes dels factors primers de 60; per tant, si els divisors són el resultat de productes dels factors primers de 60, si multipliquem factors primers de 60 , obtindrem els divisors. I si a més ho fem ordenadament per no deixar-nos-en cap, els tindrem tots. Vet ací que ja tenim el mètode: multiplicarem ordenadament els factors primers de 60 i obtindrem els seus divisors.

Ho fem. Calculem tots els divisors de 60.

1. Per a saber el nombre de divisors d'un nombre cal escriure la descomposició factorial del nombre com a producte de potències (si escau) i fer el producte de l'exponent més una unitat de cadascun dels factors. Aquest pas ajuda a comprovar si ens hem deixat algun o al contrari, si ens hem passat. $60=2^{2} \times 3^{1} \times 5^{1}$. Aleshores el nombre de divisors serà: $(2+1) \times(1+1) \times(1+1)=12$.

2. Determinem els divisors que es deriven de cadascun dels factors:
$\mathrm{D}\left(2^{2}\right)=\mathrm{D}(4)=\{1,2,4\}$
$\mathrm{D}(3)=\{1,3\}$
$\mathrm{D}(5)=\{1,5\}$

3. Construïm un esquema amb els divisors obtinguts i resolem tots els productes que s'hi poden formar, els quadres finals seran els 12 divisors de 60: 

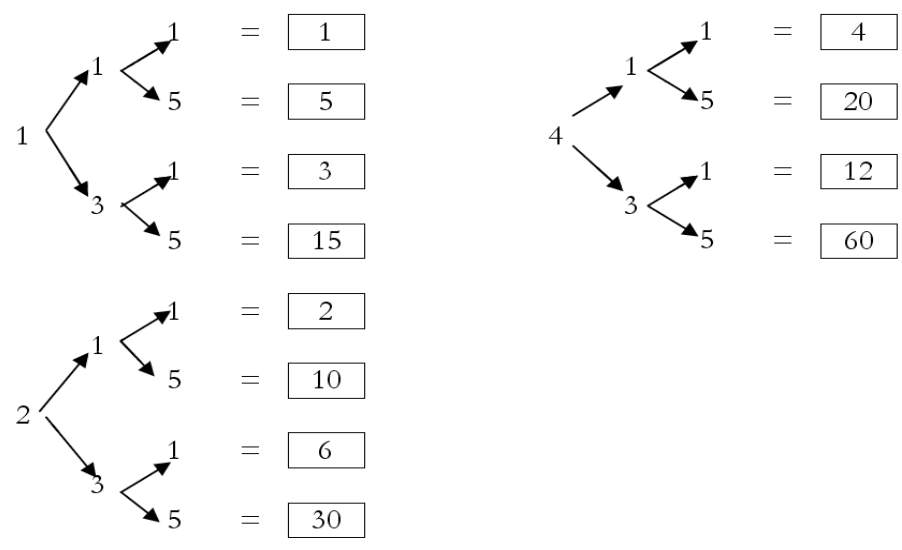

$$
\mathrm{D}(60)=\{1,2,3,4,5,6,10,12,15,20,30,60\}
$$

Com que ens trobem en 6è de Primària, el treball amb nombres primers i compostos es desenvoluparà majoritàriament amb llapis i paper, però, en cas que aquests conceptes no queden suficientment clars, es pot optar per usar material que ho aclarisca.

Per exemple, amb reglets Cuisenaire se'ls distribuiria per grups suficient quantitat de material amb la indicació següent: cal triar un reglet qualsevol diferent del blanc i trobar-ne els divisors del nombre representat pel reglet. Per aconseguir-ho, formaran tots els trens possibles la longitud dels quals serà la del reglet inicial, on cada tren estarà construït amb un mateix tipus de reglet.

L'objectiu final és diferenciar reglets que sols es poden associar amb trens formats per ells mateixos o per reglets blancs (representen nombres primers), dels que a més es poden associar a altres trens (representen nombres compostos).

\section{Màxim comú divisor (mcd)}

\subsection{Introducció}

Des de la introducció al tema, s'ha associat el terme divisor al de factor. Pel punt anterior, queda clar que els divisors d'un nombre s'obtenen a partir dels factors primers d'aquest nombre.

Per alguna fosca raó, la denominació d'aquest concepte sembla fer referència a un nombre més gran dels que es calcula. Tal vegada perquè el concepte comença amb la paraula màxim. Però només és una idea. Una proposta de canvi de nom seria divisor comú màxim. Arribats a aquest punt, la resta de l'apartat 5 d'aquest tema es dedicarà a justificar amb un exemple el canvi de nom proposat i com aquesta denominació potencia el mètode per a calcular-lo, fent així que nom i mètode caminen junts, qüestió que en aquest concepte no sempre s'ha aconseguit, agreujat a més a més pel fet que el denominem per les inicials mod. 
Considerem la següent situació problemàtica:

«Un pastisser utilitza 20 gots de farina en la recepta de magdalenes i 30 gots en la recepta dels panells suïssos. Però és massa laboriós mesurar la farina got a got, per la qual cosa decideix usar un recipient més gran. Quina ha de ser la capacitat, en gots, del major recipient possible que li valga per mesurar la farina d'ambdues receptes?».

\subsection{Construcció del concepte}

En un primer moment no ha d'aparèixer per cap lloc a l'aula de Primària el nom de divisor, ni comú, ni màxim. És un exemple que es planteja a classe com una qüestió matemàtica que el mestre proposa perquè li ho han preguntat. Amb «una pluja d'idees» els xiquets i les xiquetes poden donar els seus possibles resultats de la capacitat del recipient: de 2 gots ho és, de 5 gots també ho és... Ens interessa qualsevol?

El dubte els ha de fer pensar que no, que interessa aquell recipient que simplifique la feina, és a dir, aquell la capacitat de farina del qual puga dividir la quantitat equivalent a 20 i a 30 gots, i que siga necessari utilitzar aquest recipient la mínima quantitat de vegades per realitzar l'activitat. Per tant, serà un divisor de 20 i 30, un divisor comú, i estarem buscant el major.

En aquest moment cal obtenir tots els divisors de 20 i 30, triar els comuns i d'aquests el major:

1. Calcular tots els divisors de 20 i 30. Aplicaran la forma que ja han après. Aleshores, la primera qüestió és calcular les respectives descomposicions en factors primers de 20 i 30 :

$$
\begin{aligned}
& 20=2^{2} \times 5 \quad 30=2 \times 3 \times 5 \\
& D(20)=\{1,2,4,5,10,20\} \\
& D(30)=\{1,2,3,5,6,10,15,30\}
\end{aligned}
$$

2. Trobar els divisors comuns mitjançant la intersecció dels dos conjunts anteriors:

$\mathrm{D}(20) \cap \mathrm{D}(30)=\{1,2,5,10\}$

\section{Triar el major divisor comú:} màx. $[\mathrm{D}(20) \cap \mathrm{D}(30)]=10$

Com que es busca la capacitat en gots del major recipient possible, aquesta serà de 10 gots: $\operatorname{mcd}(20,30)=10$.

Per tornar al context de treball, respondrem a la pregunta de la situació problemàtica de partida: «La capacitat en gots del major recipient possible per mesurar la farina d'ambdues receptes, serà de 10 gots»». 
Després de treballar alguns exemples d'aquest tipus, es podria fer la pregunta «és necessari obtenir sempre tots els divisors dels dos nombres o podem buscar aquest divisor comú d'una altra manera?».

Caldria arribar al consens que aquest divisor comú el podem obtenir també multiplicant els factors que estiguen en el 20 i que també estiguen en el 30: 2 i 5. El nombre així obtingut és divisor comú perquè divideix els dos i és el màxim perquè no hi ha cap divisor més gran que hi siga comú. El nombre buscat és, per tant, 10 $=2 \times 5$.

Aleshores, hem construït un nombre que és divisor comú màxim dels altres dos.

\subsection{Automatització del concepte}

Recorrerem els passos següents:

1. Com que hem de buscar un divisor comú, factoritzem els nombres de la millor manera coneguda, en factors primers, expressant-ho en forma multiplicativa, sense utilitzar potències. $\left(^{*}\right)$

2. Triem tots els factors que estiguen al mateix temps en les dues descomposicions, sense deixar-nos-en cap, per tal d'aconseguir que el resultat siga divisor dels dos nombres i siga el més gran. No hi posem els que no coincidisquen, perquè han de ser comuns.

\section{Mínim comú múltiple (mcm)}

\subsection{Introducció}

Seguint amb la mateixa idea, el que s'intentarà és construir el concepte de la manera més intuïtiva possible i per això s'haurà de partir d'un exemple que els puga motivar.

«Dos amics corren al voltant del pati del col·legi. El primer tarda 60 segons a fer una volta completa i el segon, 65 segons. Si parteixen junts des de la línia d'eixida, quant de temps tardaran a tornar a coincidir-hi, per primera vegada?»

Aquest exemple posa de manifest que el que busquem és un nombre més gran que 60 i 65. Però torna a entrar en conflicte amb mínim, que és la primera paraula del nom del concepte. La proposta de nom és ara múltiple comú mínim. 


\subsection{Construcció del concepte}

Com que és un concepte que s'explicarà després del màxim comú divisor, part del camí de construcció és semblant, $\mathrm{i}$ els alumnes l'hauran de recórrer més ràpidament. Una vegada estiga clar que el nombre buscat ha de ser un múltiple de 60 i 65, major que qualsevol d'aquests, caldrà obtenir els múltiples distints de zero d'ambdós i trobar els que coincidisquen, però com que volem saber quant de temps tardaran a tornar a coincidir en la línia d'eixida per primera vegada, ens interessa el més menut.

En aquest moment cal obtenir múltiples distints de zero de 60 i 65, triar els comuns i d'ells el menor:

1. Calcular múltiples distints de zero de 60 i 65 $\mathrm{M} *(60): 60,120,180,240,300,360,420,480,540,600,660,720,780$, $840,900,960,1.020,1.080,1.140,1.200,1.260,1.320,1.380,1.440,1.500$, $\mathbf{1 . 5 6 0}, 1.620 \ldots$ $\mathrm{M} *(65): 65,130,195,260,325,390,455,520,585,650,715, \mathbf{7 8 0}, 845,910$, $975,1.040,1.105,1.170,1.235,1.300,1.365,1.430,1.495, \mathbf{1 . 5 6 0}, 1.625 \ldots$

2. Trobar els múltiples distints de zero comuns $\mathrm{M}^{*}(60) \cap \mathrm{M} *(65): 780,1.560 \ldots$

3. Triar el menor múltiple distint de zero comú mín $\left[M^{*}(60) \cap M^{*}(65)\right]=780$.

Com que es busca quant de temps tardaran a tornar a coincidir per primera vegada en la línia d'eixida, aquest serà de 780 segons: $\operatorname{mcm}(60,65)=780$.

Per tornar al context del treball, respondrem a la pregunta de la situació problemàtica de partida: «Tardaran 780 segons a tornar a coincidir en la línia d'eixida per primera vegada».

Després de treballar alguns exemples d'aquest tipus, es podria fer la pregunta «és necessari obtenir sempre molts múltiples dels dos nombres o podem buscar aquest múltiple comú d'una altra manera?».

S'ha d'arribar a pensar que sí que pot haver-hi un altre mètode. Aleshores busquem un múltiple distint de zero, que ho siga dels dos, per tant, comú i que a més siga el menor de tots, per tant, mínim. Recordant la factorització en factors primers, utilitzada en l'apartat anterior, els proposarem aprofitar-la per calcular també aquest múltiple. Factoritzem els nombres:

$$
\begin{aligned}
& 60=2 \times 2 \times 3 \times 5 \\
& 65=5 \times 13
\end{aligned}
$$


Com que el concepte de múltiple s'ha treballat molt des de la multiplicació, ja saben que un múltiple d'un nombre es pot aconseguir multiplicant per qualsevol valor aquest nombre.

Com que $60=2 \times 2 \times 3 \times 5$, qualsevol múltiple de 60 serà del tipus:

$$
2 \times 2 \times 3 \times 5 \times \text { A. }
$$

Igualment, com que $65=5 \times 13$, qualsevol múltiple de 65 serà del tipus:

$$
5 \times 13 \times \text { B. }
$$

La qüestió seria trobar els valors menors de $\mathrm{A}$ i $\mathrm{B}$, perquè:

$$
2 \times 2 \times 3 \times 5 \times A=5 \times 13 \times B
$$

i aleshores tindrem el menor múltiple distint de zero comú. Però aquesta qüestió és molt senzilla, perquè per cada nombre, el seu factor desconegut és el factor o producte de factors que hi ha en l'altre nombre i que no estan en la seua factorització:

$$
\mathrm{A}=13 \quad \mathrm{~B}=2 \times 2 \times 3 .
$$

És a dir, construïm un nombre amb tots els factors possibles dels dos:

$$
2 \times 2 \times 3 \times 5 \times 13 .
$$

Aquest nombre, que és el 780, és el format per tots els factors de 60 i 65 sense repetir-ne cap (mínim). Si encara els hi quedara cap dubte, es comprova que és múltiple dels dos:

$$
\begin{aligned}
& 780=60 \times 13 \\
& 780=65 \times 2 \times 2 \times 3 .
\end{aligned}
$$

I, per tant, és comú.

Aleshores, hem construït un nombre que és múltiple comú mínim dels altres dos.

\subsection{Automatització del concepte}

Recorrerem els passos següents:

1. Com que hem de buscar un múltiple comú distint de zero (format per factors a banda dels propis), factoritzem els nombres de la millor manera coneguda, en factors primers, expressant-ho en forma multiplicativa, sense utilitzar potències. $(*)$

2. Triem tots els factors que estiguen en les factoritzacions, sense deixar-nosen cap, però sense repetir els factors presents en les descomposicions de més d'un nombre, per tal d'aconseguir que el resultat siga múltiple dels nombres i el més menut. 
(*) Nota: Tradicionalment, s'ha utilitzat la descomposició en factors primers expressada en forma de potències, triant els comuns amb el menor exponent per al cas del màxim comú divisor. Aquesta automatització implica molta memòria i el fet de no raonar què és el que s'està fent. Provoca molta confusió per dues qüestions. A la ja comentada dificultat de màxim al nom del concepte, ara se li ha d'afegir la paraula menor exponent. La segona confusió apareix en el mínim comú múltiple, l'automatització tradicional consisteix a triar els comuns $i$ no comuns amb el major exponent.

La barreja entre màxim, mínim, major i menor fa que s'acabe l'etapa d'Educació Primària amb un problema greu d'identificar i separar aquests conceptes. La proposta és, doncs, abandonar aquest grau d'automatització i quedar-nos amb el que s'ha proposat abans, a més a més de llegir en diferent ordre els noms d'aquests dos conceptes. 


\section{ANNEX}

Presentem a continuació alguns conceptes bàsics de la Teoria de Conjunts, necessaris per fonamentar els continguts referents als Nombres Naturals que es treballen en aquesta publicació. No són objecte d'estudi pels futurs mestres, però tenen la finalitat de facilitar la seua consulta, als lectors que ho necessiten.

\section{Formalització de conceptes de Teoria de Conjunts}

La Teoria de Conjunts és l'encarregada de simbolitzar el llenguatge matemàtic. És per això que formant conjunts expressem alguns conceptes que componen el currículum escolar i afavorim el seu aprenentatge.

Presentem a continuació una breu formalització dels conceptes de Teoria de Conjunts, necessaris per treballar els continguts d'aquesta publicació.

\subsection{Introducció}

El concepte de conjunt és intuïtiu i es podria entendre com «una agrupació d'elements feta amb qualsevol criteri». El criteri pot no ser una propietat característica comuna, sinó simplement el desig o la necessitat d'agrupar certs elements. Així, podem parlar d'un conjunt de persones, de ciutats, de bolígrafs, o del conjunt d'objectes que hi ha en un moment determinat damunt d'una taula.

Un conjunt està ben determinat si se sap si un element donat pertany o no al conjunt; així, el conjunt dels bolígrafs blaus està ben definit, perquè en veure un bolígraf podem saber si és blau o no. El conjunt de les persones altes no està ben definit, perquè, en veure una persona, no sempre es podrà dir si és alta o no, o pot haver-hi diferents persones que opinen si aquella persona és alta o no ho és.

Els conjunts es representen, normalment, amb una lletra majúscula: $A, B, K \ldots$

Anomenarem element cadascun dels objectes (físics o abstractes) que formen part d'un conjunt. Aquests elements tenen caràcter individual, qualitats que ens permeten diferenciar-los i cadascun és únic, de manera que no hi ha elements duplicats o repetits. Els representarem generalment amb una lletra minúscula: $a, b, k \ldots$

Es defineix cardinal d'un conjunt com «la quantitat d'elements que hi ha en el conjunt». 
S'anomena conjunt universal o referencial, que habitualment representarem amb la lletra $U$, al conjunt de totes les coses de les quals s'estiga tractant; així, si parlem de Nombres Naturals, $U$ és el conjunt dels Nombres Naturals; si parlem de ciutats, $U$ és el conjunt de totes les ciutats; aquest conjunt universal pot esmentar-se explícitament $\mathrm{o}$, en la majoria dels casos, es dóna per conegut atès el context que s'estiga treballant.

Sempre ha estat molt utilitzada la idea de conjunt al llarg de la història, en qualsevol representació o explicació matemàtica. Però no serà fins al segle XIX quan se li atorgarà rigor. En aquest segle, Cantor, posa les bases per la construcció de la Teoria de Conjunts: definicions, introducció a cardinals, conjunt ben ordenat...

Apareixen escletxes en aquesta teoria, com ara la paradoxa de Russell, que sorgeix quan es suposa un conjunt $A=\{C$ conjunts / $C \notin C\}$, a partir del qual es fa la pregunta de la pertinença de $\mathrm{A}$ a si mateix, és a $\operatorname{dir} A \in A \leftrightarrow A \notin A$. La resposta ens du a la conclusió que $i A \in A o A \notin A$ ?, que constitueix la paradoxa esmentada.

Per tal de resoldre aquests problemes de la Teoria de Conjunts es creen els sistemes axiomàtics corresponents (són conjunts d'afirmacions admeses com a vertaderes sense necessitat de demostració) i així tenim els de Zermelo-Frenkel, els de Newman...

\subsection{Conjunts}

En aquest apartat es fa un recorregut per alguns conceptes (operacions, relacions...) que es poden definir en relació als conjunts.

\subsubsection{Definicions i conceptes bàsics}

Com s'ha esmentat al punt anterior, s'admet la idea de conjunt com l'agrupació en un tot de determinats objectes ben caracteritzats i diferenciats els uns dels altres.

- Conjunts iguals: aquells que, element a element, són iguals.

- Determinacions d'un conjunt:

- Per comprensió: explicitant la propietat característica dels seus elements.

- Per extensió: enumerant, un per un, tots els elements que el componen.

- Representacions d'un conjunt:

- Representació gràfica: diagrama lineal, diagrama de Venn (línia corba tancada que delimita els elements del conjunt) o qualsevol altra línea tancada.

- Representació simbòlica: com s'ha esmentat abans, s'utilitzaran lletres en minúscula per tal de representar els elements d'un conjunt i en majúscula per representar els conjunts. 
- Subconjunts: $A \subset C \leftrightarrow \forall a \in A \rightarrow a \in C$.

- Conjunt universal o referencial: es representa amb la lletra $U$.

- Conjunt complementari d'un subconjunt:

$A \subset U: A_{U}^{c}=\{x \in U / x \notin A\}$

- Conjunt buit: $\Phi$, aquell que no té cap element.

- Conjunt de parts d'un conjunt: és un conjunt que està format per tots els subconjunts d'un conjunt donat, és a dir: $P(A)=\{B / B \subset A\}$. És important notar que d'aquesta definició es dedueix que $A \in P(A)$ i $\Phi \in P(A)$.

Utilitzant nombres combinatoris es pot demostrar que el conjunt $P(A)$ té com a cardinal $2^{\operatorname{card}(A)}: \operatorname{card}[P(A)]=2^{\operatorname{card}(A)}$.

\subsubsection{Operacions entre conjunts}

- Unió: $A \cup B=\{x / x \in A \vee x \in B\}$

- Intersecció: $A \cap B=\{x / x \in A \wedge x \in B\}$. Si la intersecció de dos conjunts és el conjunt buit, aquests s'anomenen conjunts disjunts.

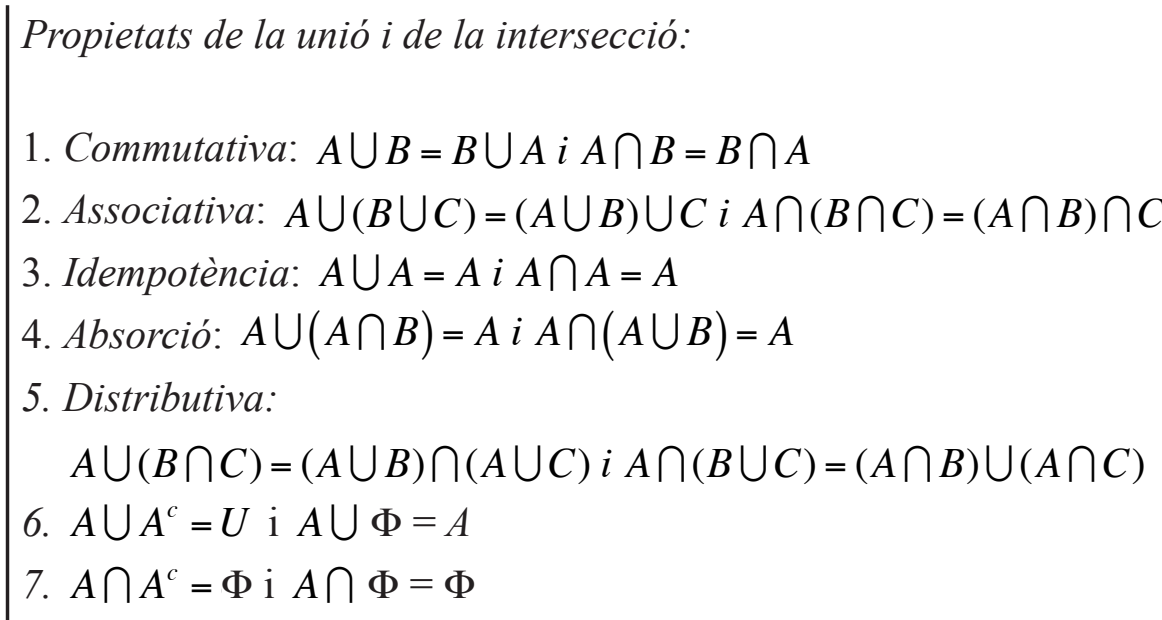

Nota: Lleis de De Morgan:

- $(A \cup B)^{C}=A^{C} \cap B^{C}$

- $(A \cap B)^{C}=A^{C} \cup B^{C}$

- Partició d'un conjunt: $\left\{N_{1}, N_{2}, \ldots, N n\right\}$ és una partició d'un conjunt $A$, si i només si (en endavant sii): 


$$
\begin{aligned}
& \text { 1. } N_{i} \subset A \wedge N_{i} \neq \Phi, \forall i=1, \ldots, n \\
& \text { 2. } \bigcup_{i=1}^{n} N_{i}=A \\
& \text { 3. } N_{i} \cap N_{j}=\Phi, \forall i \neq j
\end{aligned}
$$

- Diferència de conjunts: $A-B=\{x \in A / x \notin B\}$

- Producte cartesià: $A \times B=\{(a, b) / a \in A \wedge b \in B\}$

$$
\mid \begin{aligned}
& \text { Propietats: } \\
& \operatorname{card}(A \times B)=\operatorname{card}(A) \cdot \operatorname{card}(B) \\
& A^{\prime} \subset A, B^{\prime} \subset B \leftrightarrow A^{\prime} \times B^{\prime} \subset A \times B \\
& A \times B=\Phi \leftrightarrow A=\Phi \vee B=\Phi \\
& A \times(B \bigcup C)=(A \times B) \cup(A \times C) \\
& A \times(B \cap C)=(A \times B) \cap(A \times C) \\
& A \times(B-C)=(A \times B)-(A \times C)
\end{aligned}
$$

\subsection{Correspondències}

Una correspondència $\mathbf{f}$ és una terna $(\mathbf{A}, \mathbf{B}, \mathbf{G})$, on:

- A, B són conjunts i $f: A \rightarrow B$ associa elements d'A amb elements de $\mathbf{B}$, anomenant-se A conjunt inicial i B conjunt final.

- $D(f)=\{x \in A / \exists y \in B: f(x)=y\}$, és el conjunt domini de la correspondència i està format pels elements (anomenats origen o antiimatge) del conjunt inicial que tenen algun element corresponent en el conjunt final.

- $\operatorname{Im}(f)=\{y \in B / \exists x \in A: f(x)=y\}$ és el conjunt imatge de la correspondència i està format pels elements (anomenats imatge) del conjunt final que es corresponen amb algun element del domini de la correspondència.

- $G \subset A x B$, s'anomena Graf de la correspondència i està format pels parells $(\mathbf{x}, \mathbf{y})$ on $x \in D(f)$ i $y \in \operatorname{Im}(f)$ :

$G(f)=\{(x, y) \in A \times B / x \in D(f) \wedge y \in \operatorname{Im}(f) \wedge f(x)=y\}$ 
- Qualsevol correspondència $\mathbf{f}$ ens permet definir la seua correspondència recíproca o inversa, de la manera següent:

$$
f^{-1}: B \rightarrow A / D\left(f^{-1}\right)=\operatorname{Im}(f) i \operatorname{Im}\left(f^{-1}\right)=D(f) .
$$

Algunes correspondències poden ser:

- Unívoca: a cada element de A li correspon un element o cap de B.

- Biunívoca: tant f, com $f^{-1}$, són unívoques.

- Aplicació: tot element de $A$ té imatge en $B$ i aquesta és única. És a dir, $\forall a \in A, \exists ! b \in B / f(a)=b$.

\begin{tabular}{|l} 
Algunes aplicacions poden ser: \\
- Suprajectiva: tot element de B és imatge d'algun el \\
$\quad \forall b \in B, \exists a \in A / f(a)=b$ \\
- Injectiva: elements distints de A tenen imatges distint \\
$\quad \forall a, b \in A: a \neq b \rightarrow f(a) \neq f(b)$ \\
- Bijectiva: suprajectiva i injectiva al mateix temps.
\end{tabular}

- Composició d'aplicacions: donada una aplicació $f: A \rightarrow B$, $i$ una altra $g: B \rightarrow C$ de forma que $\forall a \in A \quad f(a)=b \wedge \forall b \in B \quad g(b)=c$, es defineix la composició d'aplicacions com una altra aplicació $g \circ f: A \rightarrow C$, $i$ es compleix que $\forall a \in A \quad g \circ f(a)=g(f(a))=g(b)=c$. Si les aplicacions $f$ i $g$ són bijectives, la seua composició $f$ o $g$ també ho és.

\subsection{Relacions binàries}

Una relació binària és una associació o connexió que s'estableix entre parelles d'elements d'un conjunt. Pot haver-hi moltes definides en un mateix conjunt. Analíticament, podem dir que una relació $\mathbf{R}$ és una terna $(\mathbf{A}, \mathbf{A}, \mathbf{G})$, on $G \subset A \times A$, com ocorre al punt anterior, aleshores direm que $\mathbf{x} \mathbf{R y} \operatorname{sii}(\mathbf{x}, \mathbf{y})$ pertany a $\mathbf{G}$.

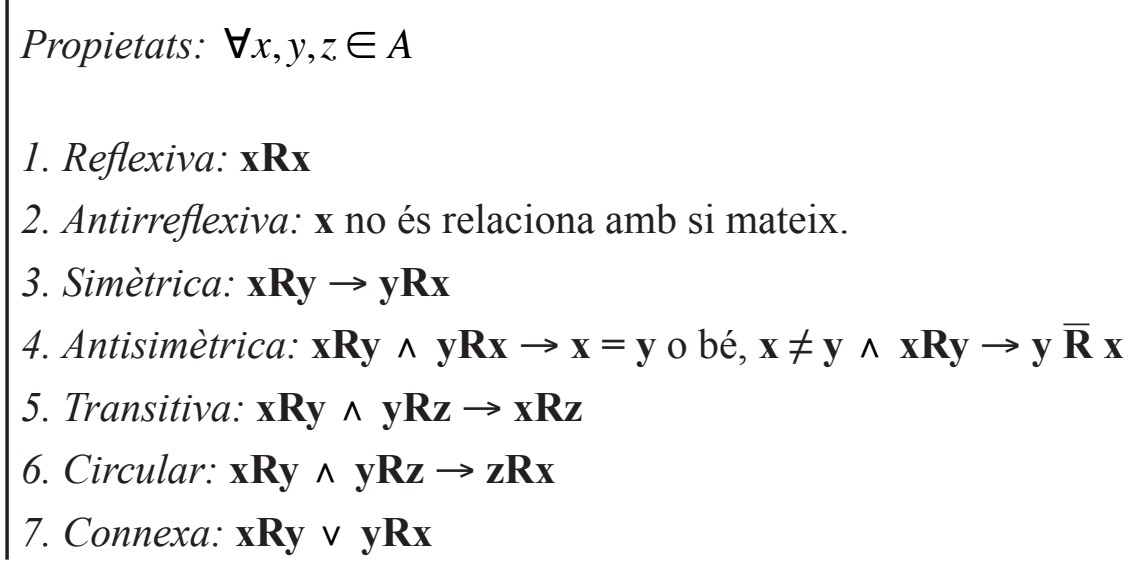


Nota: si una relació binària definida en un conjunt compleix algunes de les propietats anteriors, rep el nom de:

- Relació binària d'equivalència: compleix reflexiva, simètrica i transitiva.

- Relació binària de preordre: compleix reflexiva i transitiva.

- Relació binària d'ordre (també anomenada d'ordre ampli): compleix reflexi$v a$, antisimètrica i transitiva.

- Relació binària d'ordre estricte: compleix antireflexiva, antisimètrica i transitiva.

- Qualsevol relació d'ordre definida anteriorment s'anomenen de ordre parcial, perquè no se l'hi ha exigit que complisca la propietat connexa. Si aquesta propietat es compleix, les relacions d'ordre s'anomenen de ordre total.

\subsubsection{Classes d'equivalència}

Una relació binària d'equivalència definida en un conjunt, organitza els seus elements en subconjunts que constitueixen una partició del conjunt (vegeu annex 1.2.2). Aquesta organització s'anomena classificació i cadascun dels subconjunts s'anomena classe d'equivalència i està format pels elements del conjunt que es relacionen mitjançant la relació.

\subsubsection{Conjunt quocient}

Una vegada establerta una classificació, les classes d'equivalència formen un conjunt que s'anomena conjunt quocient. Si $A$ és el conjunt on tenim definida la relació d'equivalència $R$, el conjunt quocient es representa per $A / R$.

\subsection{Estructures algebraiques}

Quan s'estudien les propietats de les operacions en els diferents conjunts numèrics, s'observen algunes que es repeteixen de manera regular en tots, i d'altres que es presenten de manera específica. Aquestes contribueixen a determinar l'estructura algebraica dels esmentats conjunts numèrics.

En general, quan parlem d'estructura algebraica ens referim a les propietats que compleixen les operacions definides entre els elements d'un conjunt. D'acord amb aquestes s'estableix una classificació dels conjunts, en la qual cadascuna de les classes d'equivalència correspon a una de les estructures que es recullen a continuació. 
Les operacions necessàries per determinar una estructura poden ser internes o externes:

- Es defineix operació interna, com una aplicació (*) $: \mathbf{A} \times \mathbf{A} \rightarrow \mathbf{A}$. És a dir, operant elements d'un conjunt $\mathbf{A}$, obtenim elements del mateix conjunt.

- Es defineix operació externa, com una aplicació $(\cdot): \mathbf{K} \times \mathbf{A} \rightarrow \mathbf{A}$. És a dir, operant elements d'un conjunt $\mathbf{A}$ amb elements d'un altre conjunt $\mathbf{K}$, anomenat d'escalars, obtenim elements del conjunt $\mathbf{A}$.

Les operacions definides poden complir algunes de les propietats següents:

- Associativa (asso): $\forall a, b, c \in A:(\mathbf{a} * \mathbf{b}) * \mathbf{c}=\mathbf{a} *(\mathbf{b} * \mathbf{c})$

- Commutativa (com): $\forall a, b \in A: \mathbf{a} * \mathbf{b}=\mathbf{b} * \mathbf{a}$

- Element neutre (en): $\exists n \in A / \forall a \in A: \mathbf{a} * \mathbf{n}=\mathbf{n} * \mathbf{a}=\mathbf{a}$

- Element simètric (es): $\forall a \in A, \exists a^{\prime} \in A / \mathbf{a}^{*} \mathbf{a}^{\prime}=\mathbf{a}^{*} \mathbf{a}^{\prime}=\mathbf{n}$

- Distributiva de $\bullet$ respecte de $*: \forall \mathrm{a}, \mathrm{b} \in \mathrm{A} \wedge \forall \mathrm{k} \in \mathrm{K}: \mathrm{k} \bullet(\mathbf{a} * \mathbf{b})=(\mathbf{k} \bullet \mathbf{a}) *(\mathbf{k} \cdot \mathbf{b})$

Les principals estructures són:

Per a l'operació interna:

\begin{tabular}{|c|c|c|c|c|}
\hline & Associativa & Commutativa & $\begin{array}{l}\text { Element } \\
\text { neutre }\end{array}$ & $\begin{array}{l}\text { Element } \\
\text { simètric }\end{array}$ \\
\hline Semigrup & $\mathrm{X}$ & & & \\
\hline $\begin{array}{l}\text { Semigrup } \\
\text { commutatiu }\end{array}$ & $X$ & $\mathrm{X}$ & & \\
\hline Monoide & $\mathrm{X}$ & & $\mathrm{X}$ & \\
\hline $\begin{array}{l}\text { Monoide } \\
\text { commutatiu }\end{array}$ & $\mathrm{X}$ & $\mathrm{X}$ & $X$ & \\
\hline Grup & $\mathrm{X}$ & & $\mathrm{X}$ & $\mathrm{X}$ \\
\hline $\begin{array}{l}\text { Grup } \\
\text { commutatiu o abelià }\end{array}$ & $X$ & $\mathrm{X}$ & $X$ & $X$ \\
\hline
\end{tabular}


Per a dues operacions internes:

\begin{tabular}{|c|c|c|c|c|c|c|c|c|c|}
\hline & \multicolumn{4}{|c|}{ Primera operació } & \multicolumn{4}{|c|}{ Segona operació } & \multirow{2}{*}{$\begin{array}{c}\text { Distributiva } \\
\text { de la } 2 a \\
\text { respecte } \\
\text { de la } 1 \text { la }\end{array}$} \\
\hline & asso & $\mathrm{com}$ & en & es & asso & com & en & es & \\
\hline Semianell & $\mathrm{X}$ & $\mathrm{X}$ & $\mathrm{X}$ & & $\mathrm{X}$ & & & & $\mathrm{X}$ \\
\hline $\begin{array}{l}\text { Semianell } \\
\text { commutatiu }\end{array}$ & $X$ & $\mathrm{X}$ & $X$ & & $\mathrm{X}$ & $\mathrm{X}$ & & & $\mathrm{X}$ \\
\hline $\begin{array}{l}\text { Semianell } \\
\text { commutatiu } \\
\text { unitari }\end{array}$ & X & X & $X$ & & $X$ & $X$ & $X$ & & $X$ \\
\hline Anell & $\mathrm{X}$ & $\mathrm{X}$ & $\mathrm{X}$ & $\mathrm{X}$ & $\mathrm{X}$ & & & & $\mathrm{X}$ \\
\hline $\begin{array}{l}\text { Anell } \\
\text { commutatiu }\end{array}$ & $\mathrm{X}$ & $\mathrm{X}$ & $\mathrm{X}$ & $X$ & $\mathrm{X}$ & $\mathrm{X}$ & & & $\mathrm{X}$ \\
\hline $\begin{array}{l}\text { Anell } \\
\text { commutatiu } \\
\text { unitari }\end{array}$ & $\mathrm{X}$ & $\mathrm{X}$ & $X$ & $X$ & $\mathrm{X}$ & $\mathrm{X}$ & $X$ & & $\mathrm{X}$ \\
\hline Cos & $\mathrm{X}$ & $X$ & $\mathrm{X}$ & $\mathrm{X}$ & $X$ & & $\mathrm{X}$ & $\underset{(*)}{X}$ & $X$ \\
\hline $\begin{array}{l}\text { Cos } \\
\text { commutatiu }\end{array}$ & $\mathrm{X}$ & $\mathrm{X}$ & $X$ & $X$ & $\mathrm{X}$ & $\mathrm{X}$ & $X$ & $\underset{(*)}{X}$ & $\mathrm{X}$ \\
\hline
\end{tabular}

(*): Exceptuant l'element neutre de la primera, tots els elements del conjunt tenen simètric per a la segona operació.

Caldria afegir, finalment, les definicions de semimòdul i espai vectorial:

Un conjunt $(\mathrm{M}, *, \cdot)$, amb una operació interna $(*)$ i una altra externa $(\cdot)$, definida amb l'ajuda d'un semianell $(\mathrm{A},+, \times)$, és un semimòdul si:

- $(M, *)$ és un semigrup commutatiu.

- $\forall \alpha, \beta \in A \wedge \forall a, b \in M$ es compleixen les propietats següents:

$-(\alpha+\beta) \cdot a=(\alpha \cdot a) *(\beta \cdot a)$

$-\alpha \cdot(a * b)=(\alpha \cdot a) *(\alpha \cdot b)$

$-\alpha \cdot(\beta \cdot a)=(\alpha \times \beta) * a$ 
Un conjunt $(\mathbf{V}, *, \cdot)$, amb una operació interna $(*)$ i una altra externa $(\cdot)$ definida amb l'ajuda d'un $\cos (\mathbf{K},+, \times)$ és un espai vectorial si:

- $(\mathbf{V}, *)$ és un grup abelià.

- $\forall u, v \in V, \forall \lambda, \mu, 1 \in K$ es compleixen les propietats següents:

$-(\lambda+\mu) \cdot v=(\lambda \cdot v) *(\mu \cdot v)$

$-\lambda \cdot(\mathrm{u} * \mathrm{v})=(\lambda \cdot \mathrm{u}) *(\lambda \cdot \mathrm{v})$

$-\lambda \cdot(\mu \cdot v)=(\lambda \times \mu) \cdot v$

$-1 \cdot \mathrm{v}=\mathrm{v}$ 


\section{Referències bibliogràfiques}

BARBA, D. (2004): «Matemàtiques des d'un punt de vista constructivista o constructivisme des d'un punt de vista matemàtic?». Barcelona. Guix, 309. Novembre 2004.

Bishop, A. J. (1999): Enculturación matemática. La educación matemática desde una perspectiva cultural. Paidós. Barcelona.

Chevallard, Y. i altres (1997): Estudiar matemáticas. El eslabón perdido entre enseñanza y aprendizaje. IcE Universitat de Barcelona-Editorial Horsori. Barcelona.

Gómez, B. (1988): Numeración y cálculo. Colección Matemáticas: cultura y aprendizaje, núm. 3. Síntesis. Madrid.

Gallego, C. i altres (2005): Repensar el aprendizaje de las matemáticas. Matemáticas para convivir comprendiendo el mundo. Graó. Barcelona.

Ifrah, G. (2001): Historia universal de las cifras. La inteligencia de la humanidad contada por los números y el cálculo. Espasa Calpe. Madrid.

- (1988): Las cifras. Historia de una gran invención. Alianza Editorial. Madrid.

Polya, G. (1992): Cómo plantear y resolver problemas. Trillas. Mèxic.

\section{Bibliografia recomanada}

Alsina, C. i altres (1995): Ensenyar matemàtiques. Graó. Barcelona.

Balaux, A. (2003): Manual de matemàtiques del professor de primària. Ed. de la Universitat de Barcelona. Barcelona.

BINIÉs, P. (2008): Conversaciones matemáticas con M. ${ }^{a}$ Antònia Canals: o cómo hacer de las Matemáticas un aprendizaje. Graó. Barcelona.

CAnAls, M. ${ }^{a}$ A. (2009): Primers nombres i primeres operacions. Rosa Sensat. Barcelona.

- (2010): Problemes i més problemes. Rosa Sensat. Barcelona.

CARrillo, D. (1989): El aprendizaje del número y las Regletas de Cuisenaire. Universidad de Murcia, Secretariado de Publicaciones. Murcia.

Cascallana, M. T. (1988): Iniciación a la matemática. Materiales y recursos didácticos. Aula XXI, núm. 40. Madrid. Santillana.

Castro, E. (ed.) (2001): Didáctica de la Matemática en la Educación Primaria. Síntesis. Madrid.

Chamorro, M. C. (coord.) (2003): Didáctica de las Matemáticas. Pearson Educación. Madrid.

Codina, R. (coord.) (2004): Matemàtiques i la seua didàctica. Publicacions i Edicions UB, Textos Docents. Barcelona.

Dienes, Z. P. (1971): Cómo utilitzar los Bloques Multibase. Teide. Barcelona.

FERnÁndeZ, J. A. (1989): Los números en color de G. Cuisenaire: relaciones dinámicas para el descubrimiento de la matemática en el aula. Seco Olea, DL. Madrid. 
Forrellad, H. (2001): «Textos para calcular», Aula de Innovación Educativa, núm. 107, desembre 2001.

Godino, J. D. (dir.) (2004): Matemáticas para maestros. Departamento de Didáctica de la Matemática, Universidad de Granada. Granada.

- (2004): Didáctica de las matemáticas para maestros. Departamento de Didáctica de la Matemática, Universidad de Granada. Granada.

MAZA, C. (1995): Aritmética y representación: de la comprensión del texto al uso de materiales. Paidós. Barcelona.

Monterde, M. (2001): «El jarrón mágico. El misterio de la multiplicación», Aula de Innovación Educativa, núm. 107, desembre 2001.

Nctм (2003): Principios y estándares para la educación matemàtica. Sociedad Andaluza de Profesores de Matemáticas, Granada.

Orton, A. (1990): Didáctica de las matemáticas. Educación Infantil y Primaria. Morata SA-MEC. Madrid.

Planas, N. (2012): Teoría, crítica y práctica de la educación matemática. Graó. Barcelona.

Planas, N. y Alsina, A. (coords.) (2009): Educación matemática y buenas prácticas: infantil, primaria, secundaria y educación superior. Graó. Barcelona.

Pons, C. (2001): «¿Para qué sirven los números?», Aula de Innovación Educativa, núm. 107, desembre 2001.

Prada, M. D. DE y Rodríguez, R. (1982): Cómo enseñar la divisibilidad. Anaya. Madrid.

Rigol, Albert (2001): «Matemáticas para entender. Las matemáticas como cultura», Aula de Innovación Educativa, núm. 107, desembre 2001.

Segovia, I. i L. Rico (coords.) (2011): Matemáticas para maestros de Educación Primaria. Pirámide. Madrid.

SIERRA, M. i altres (1989): Divisibilidad. Colección Matemáticas: cultura y aprendizaje, núm. 7. Síntesis. Madrid.

TORRA, Montserrat (1993): «Una propuesta didáctica para enseñar la decena», Signos, teoría y práctica de la educación, 8/9, gener-juny 1993, pp. 178-189. 


\section{Índex de figures}

Figura 1. Imatges del material Anelles de colors

Figura 2. Imatges del material Aprenc a comptar (a)

Figura 3. Imatges del material Aprenc a comptar $(b)$. . .

Figura 4. Imatges del material Aprenc a comptar $(c) \ldots \ldots \ldots \ldots \ldots$

Figura 5. Aplicació bijectiva . . . . . . . . . . . . . . . .

Figura 6. Xifres en l'escriptura jeroglífica egípcia (Ifrah, 1988) . . . . . .

Figura 7. Escriptura jeroglífica del nombre 2.425 (Ifrah, 1988) . . . . . . .

Figura 8. Representacions numèriques en l'escriptura acrofònica grega (Ifrah, 1988)

Figura 9. Escriptura acrofònica del nombre 7699 (Ifrah, 1988) . . . . . .

Figura 10. Numeració alfabètica grega (Ifrah, 1988) . . . . . . . . .

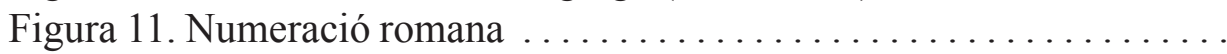

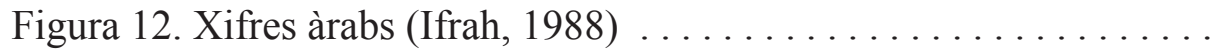

Figura 13. Evolució de les xifres àrabs a Europa (Ifrah, 1988) . . . . . . .

Figura 14. Gravat del començament del segle XVI que representa el triomf dels algorismes sobre els àbacs. Els algoristes, emprant les nou xifres i el zero, s'imposen als abaquistes, ja que són capaços de fer més ràpidament les operacions aritmètiques. En segon pla, la dama Aritmètica, amb un vestit guarnit de xifres, mostra amb la mirada quines són les seues preferències (Ifrah, 1988)

Figura 15. Blocs multibase de base 10 (esquerra) i base 2 (dreta) (fabricats per Tauvi)

Figura 16. Representació del nombre 1.324 amb blocs multibase de base 10 (fabricats per Miniland) .

Figura 17. Àbacs verticals tancats de 10 boles (esquerra) i 20 boles (dreta) (fabricats per Goula) . . . . . . . . . . . . . . . . . Figura 18. Àbac vertical obert de 3 varetes en el qual s'ha representat el nombre 62 (fabricat per Nathan) . . . . . . . . . . . . . . . . . Figura 19. Reglets Cuisenaire ordenats de l'1 al 10 (fabricats per Lado) . . Figura 20. Construcció del 10 amb blocs multibase ............ Figura 21. Construcció del 10 amb àbacs

Figura 22. Es disposen els 47 cubs de manera individual . .

Figura 23. Resultat de la primera agrupació: 1 reglet i 37 cubs solts ..... Figura 24. Resultat de la segona agrupació: 2 reglets i 27 cubs solts . . . . . Figura 25. Resultat de la tercera agrupació: 3 reglets i 17 cubs solts . . . . . Figura 26. Resultat de la quarta agrupació: 4 reglets i 7 cubs solts ...... Figura 27. Es disposen les 47 boles de manera individual al costat d'un

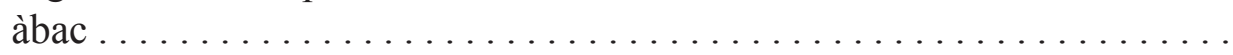
Figura 28. Procés i resultat de la primera agrupació: 1 bola a la vareta de les desenes i 37 boles soltes . . . . . . . . . . . . . . . . . . . . . Figura 29. Procés i resultat de la segona agrupació: 2 boles a la vareta de les desenes i 27 boles soltes . . . . . . . . . . . . . . . . Figura 30. Resultat de la tercera agrupació: 3 boles a la vareta de les desenes i 17 boles soltes 
Figura 31. Resultat de la quarta agrupació: 4 boles a la vareta de les desenes i 7 boles a la de les unitats . .

Figura 32. Representació amb BM de la construcció de la segona desena .... Figura 33. Representació amb àbacs de la construcció de la segona desena .

Figura 34. Construcció del 100 amb вм ..................

Figura 35. Construcció del 100 amb àbacs . . . . . . . . . . . . .

Figura 36. Representació de 147 amb вм ....................

Figura 37. Representació de 147 amb àbacs . . . . . . . . . . . . . . . .

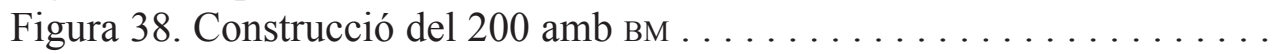

Figura 39. Construcció del 200 amb àbacs . . . . . . . . . . . . .

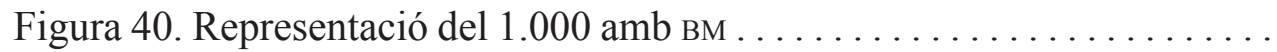

Figura 41. Representació del $1.000 \mathrm{amb}$ àbacs . . . . . . . . . . . . . .

Figura 42. Representació de l'agrupament de 2 i $3 \ldots \ldots \ldots \ldots \ldots$

Figura 43. Representació de 12 i 24 amb àbacs . . . . . . . . . . . . .

Figura 44. Representació amb àbacs del resultat de $12+24 \ldots \ldots \ldots \ldots \ldots$

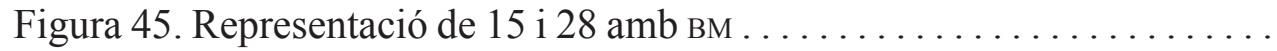

Figura 46. Representació de l'agrupació de 15 i 28 amb вм . . . . . . . . .

Figura 47. Transformació de 10 cubs en un reglet . . . . . . . . . .

Figura 48. Representació amb вм del resultat de $15+28 \ldots \ldots \ldots \ldots \ldots$

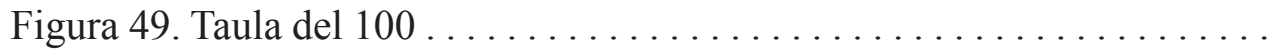

Figura 50. Representació de la manipulació de 5 menys $2 \ldots \ldots \ldots \ldots$

Figura 51. Representació de la manipulació de 5 fins a $8 \ldots \ldots \ldots \ldots$

Figura 52. Representació de la comparació entre els cardinals 4 i $6 \ldots \ldots$.

Figura 53. Representació de 27 i 12 amb àbacs . . . . . . . . . . .

Figura 54. Representació del procés de la subtracció $27-12 \ldots \ldots \ldots \ldots$

Figura 55. Representació amb àbacs del resultat de $27-12 \ldots \ldots \ldots \ldots$

Figura 56. Representació de 45 і 28 amb вм ..................

Figura 57. Representació de la transformació d'una desena del 45

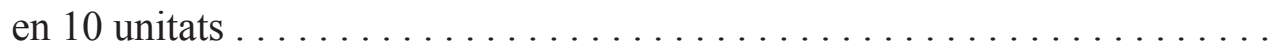

Figura 58. Representació del procés de la subtracció de 45 menys $28 \ldots \ldots$

Figura 59. Representació de 45 i 28 amb àbacs . . . . . . . . . . . . .

Figura 60. Representació amb àbacs de com s'afigen 10 unitats

als termes de $45-28$.

Figura 61. Representació amb àbacs de la transformació de 10 unitats

en una desena en el subtrahend . . . . . . . . . . . . . . . .

Figura 62. Representació amb àbacs de la subtracció en les unitats . . . . . .

Figura 63. Representació en àbacs del resultat de $45-28 \ldots \ldots \ldots \ldots$. . .

Figura 64. Representació de la unió de 3 conjunts de 6 elements .........

Figura 65. Representació del resultat de triplicar 25 amb un àbac . . . . . . .

Figura 66. Representació del resultat de multiplicar 25 per 3 amb un àbac. .

Figura 67. Imatge d'una seqüència de joc amb el Dòmino de la multiplicació

Figura 68. Imatge d'una seqüència de joc amb el Triòmino

de la multiplicació . . . . . . . . . . . . . . . . . . . . .

Figura 69. Imatge d'una seqüència de joc amb el Penkamino

Figura 70. Imatge d'una seqüència de joc amb el Bingo de la multiplicació.

Figura 71. Representació amb BM de la divisió de 64 entre $2 \ldots \ldots \ldots \ldots$ 
Figura 72. Representació amb BM del repartiment de les desenes de la divisió de 64 entre 4

Figura 73. Representació amb BM del resultat de la descomposició

de 2 reglets en 20 cubs

Figura 74. Representació amb BM del resultat del repartiment de 64

entre 4

Figura 75. Imatge d'una associació de fitxes amb el Dòmino de la divisió . . Figura 76. Imatge de les fitxes del Triòmino de la divisió . . . . . . . . . . . .

Figura 77. Imatge d'un moment del joc Mathable ................

Figura 78. Imatge del tauler d'El Mil

Figura 79. Imatge dels elements que componen el joc Top Score... 